\title{
Biological markers for exposure to polycyclic aromatic hydrocarbons
}

Citation for published version (APA):

Godschalk, R. W. L. (1999). Biological markers for exposure to polycyclic aromatic hydrocarbons.

[Doctoral Thesis, Maastricht University]. Universiteit Maastricht. https://doi.org/10.26481/dis.19991001rg

Document status and date:

Published: 01/01/1999

DOI:

10.26481/dis.19991001rg

Document Version:

Publisher's PDF, also known as Version of record

\section{Please check the document version of this publication:}

- A submitted manuscript is the version of the article upon submission and before peer-review. There can be important differences between the submitted version and the official published version of record.

People interested in the research are advised to contact the author for the final version of the publication, or visit the DOI to the publisher's website.

- The final author version and the galley proof are versions of the publication after peer review.

- The final published version features the final layout of the paper including the volume, issue and page numbers.

Link to publication

\footnotetext{
General rights rights.

- You may freely distribute the URL identifying the publication in the public portal. please follow below link for the End User Agreement:

www.umlib.nl/taverne-license

Take down policy

If you believe that this document breaches copyright please contact us at:

repository@maastrichtuniversity.nl

providing details and we will investigate your claim.
}

Copyright and moral rights for the publications made accessible in the public portal are retained by the authors and/or other copyright owners and it is a condition of accessing publications that users recognise and abide by the legal requirements associated with these

- Users may download and print one copy of any publication from the public portal for the purpose of private study or research.

- You may not further distribute the material or use it for any profit-making activity or commercial gain

If the publication is distributed under the terms of Article $25 \mathrm{fa}$ of the Dutch Copyright Act, indicated by the "Taverne" license above, 


\title{
BIOLOGICAL MARKERS FOR EXPOSURE TO POLYCYCLIC AROMATIC HYDROCARBONS
}

\author{
R.W.L. Godschalk
}


(c) Roger W. L. Godschalk

ISBN 90-9012926-X

\author{
Vormgeving: $\quad$ : Roger Godschalk \\ Omslagillustratie : Roger Godschalk \\ Omslagontwerp en druk : Datawyse Boekproducties, Maastricht
}




\title{
BIOLOGICAL MARKERS FOR EXPOSURE TO POLYCYCLIC AROMATIC HYDROCARBONS
}

\author{
PROEFSCHRIFT
}

ter verkrijging van de graad van doctor aan de Universiteit Maastricht,

op gezag van de Rector Magnificus, Prof. dr. A. C. Nieuwenhuijzen Kruseman, volgens het besluit van het College van Decanen,

in het openbaar te verdedigen op vrijdag 1 oktober 1999 om 12.00 uur

door

Roger Wilhelmus Laurentius Godschalk

geboren te Heerlen op 7 oktober 1971 


\section{Promotor:}

Prof. dr. J.C.S. Kleinjans

\section{Co-Promotor:}

Dr. F.J. Van Schooten

\section{Beoordelingscommissie:}

Prof. dr. J.W. Arends (Voorzitter)

Dr. R.A. Baan (International Agency for Research on Cancer, LARC)

Prof. dr. A. Bast

Prof. dr. E.F.M. Wouters

Prof. dr. ir. A.A. Van Zeeland (Universiteit Leiden) 
"...A day without laughter, is a day wasted....."

Charlie Chaplin 


\section{Contents}

\section{Abbreviations}

$\begin{array}{lll}\text { Chapter } 1 \quad \text { General Introduction } & 10\end{array}$

1.1 Introduction 10

1.2. Carcinogenicity of $\mathrm{PAH}$ in exposed rodents and humans 11

A. Exposure levels and routes

B. Carcinogenicity in relation to exposure routes

1.3 PAH metabolism and DNA adduct formation 13

$1.4 \quad$ PAH-DNA adducts and their role in carcinogenesis $\quad 16$
A. In vitro Studies
B. Studies in laboratory rodents
C. Studies in humans

1.5 Susceptibility for PAH-DNA adduct formation
A. Detoxification of PAH
B. Activation of PAH
C. P53 accumulation and DNA-repair

$1.6 \quad$ Exposure monitoring 20

$\begin{array}{ll}\text { 1.6.1 The Framework } & 21\end{array}$

1.6.2 Validity criteria for exposure markers 22.
A. Surrogate Tissues
B. Defined Pharmacokinetics and Temporal Relevance
C. Understanding Inter- and Intraindividual Variability
D. Comparison with other markers of PAH-exposure

1.7 Aim and outline of the thesis

Chapter 2 Differences in aromatic DNA adduct levels

between alveolar macrophages and subpopulations of white blood cells from smokers

Chapter 3 32P-postlabeling of aromatic DNA adducts in white

blood cells and alveolar macrophages of smokers:

saturation at high exposures

Chapter 4 Exposure route dependent DNA adduct formation by polycyclic aromatic hydrocarbons

Chapter 5 DNA adduct removal in mononuclear blood cells of smokers after smoking cessation

Chapter 6 Genetic polymorphisms in GSTM1 and NAT2 in relation to aromatic-DNA adducts in smokers 
$\begin{array}{llll}\text { Chapter } & 7 & \text { Aromatic DNA adducts in white blood cells }\end{array}$ and skin after dermal application of coal-tar

Chapter $8 \quad$ Impact of GSTM1 on aromatic-DNA adducts and P53 accumulation in human skin and lymphocytes.

Chapter 9 Repair of oxidative DNA damage after acute oral exposure to benzo[a]pyrene

Chapter 10 Comparison of HPLC-FD and ${ }^{32}$ P-postlabeling analysis of DNA adducts in rats acutely exposed to benzo[a]pyrene

Chapter 11 Influence of DNA isolation and RNA contamination on carcinogen-DNA adduct analysis by ${ }^{32}$ P-Postlabeling

Chapter 12 Summary and General Discussion

Samenvatting

Dankwoord

Curriculum vitae

List of publications 


\section{Abbreviations}

BAL-cells

B[a]P

BPDE

COPD

$\mathrm{CT}$

CYP

dG

DMSO

DNA

DRZ

ECD

EDTA

$\mathrm{EH}$

FCS

FD

GSH

GST

HPLC

IARC

ICC

i.p.

i.t.

MN

MNC

NAT

ND

NER

NP1

nt.

8-oxo-dG
Cells obtained by broncho-alveolar lavage

Benzo(a)pyrene

Benzo(a)pyrene-diol-epoxide

Chronic Obstructive Pulmonary Disease

Coal Tar

Cytochrome P450

Deoxyguanosine

Dimethylsulfoxide

Deoxyribose Nucleic Acid

Diagonal Radioactive Zone

Electro Chemical Detection

Ethylene Diamine Tetraacetic Acid

Epoxide Hydrolase

Fetal Calf Serum

Fluorescence detection

Glutathione

Glutathione-S-Transferase

High Performance Liquid Chromatography

International Agency for Research on Cancer

Immunocytochemistry

intraperitoneally

intratracheally

Micrococcal endonuclease

Mononucleated White blood Cells

$\mathrm{N}$-Acetyl-Transferase

Not Detectable

Nucleotide Excision Repair

Nuclease P1

Nucleotides

7-hydro-8-oxo-2'-deoxyguanosine 
PAH

(P)AM

PBS

PCR

PEI

PHA

PNK

ROS

$r_{\mathrm{s}}$

SD

SE(M)

Spd

ST

TLC

UGT

WBC
Polycyclic Aromatic Hydrocarbons

(Pulmonary) Alveolar Macrophages

Phosphate Buffered Saline

Polymerase Chain Reaction

Poly(ethylenimine)

Phytoheamagglutinine

Polynucleotide Kinase

Reactive Oxygen Species

Spearman Rank Correlation

Standard Deviation

Standard Error (of the Mean)

Spleen Phosphodiesterase

Sulphotransferase

Thin Layer Chromatography

UDP-glucuronosyl Transferase

White Blood Cells 


\section{Chapter 1}

\section{General Introduction}

\subsection{Introduction}

At the time Watson and Crick elucidated the molecular structure of deoxyribose nucleic acid (DNA) in 1953, the general conception was that DNA served as a cellular library and was therefore thought to be unalterable (1). However, later, it became clear that DNA is continuously exposed to a plethora of endogenous and exogenous compounds that are able to induce DNA damage by interacting with various sites in the DNA (2). DNA damage may result in the misincorporation of a nucleotide opposite to the damaged site during DNA replication or error-prone DNA repair. As a consequence, the nucleotide sequence is altered and the normal function of DNA or its translation products can be changed. Interference with the structural integrity of DNA is thought to be a critical initial step in chemically induced cancers, because mutations in specific cell-cycle regulatory genes may disrupt normal cell growth (2).

Many chemicals are able to interact with DNA, but most studies on chemical carcinogenesis have concentrated on alkylating agents and aromatic compounds. A lot of work has been carried out on the DNA-binding properties of polycyclic aromatic hydrocarbons (PAH)(3). PAH form a large group of structurally related compounds with two or more condensed benzene rings that are formed as products of the incomplete combustion of organic materials. The evidence that PAH are potent carcinogens in laboratory animals is overwhelming and the main organs in which tumors occur after PAH exposure seem to be skin, pulmonary, gastric and mammary tissues depending on the route of administration (4). PAH are also suspected to be carcinogenic in humans (5). PAH are widely distributed in the environment and it would be surprising if the human population was not placed at increased risk of developing cancer as a result of environmental pollution by PAH. Examples of environmental $\mathrm{PAH}$ sources are power plants, domestic and industrial heating systems, combustion engines, refuse burning and as a more localized source tobacco smoke. These sources produce mixtures that contain 100-300 different PAH, which are not all equally potent carcinogens. Benzo[a]pyrene $[\mathrm{B}(\mathrm{a}) \mathrm{P}]$, a typical PAH, is considered to be one of the main contributors to the carcinogenic properties of mixtures (3) and is commonly used as indicator of the pollution level of PAH in, for example air samples. The first clear recognition of chemically induced cancers in man by a PAH-containing mixture can be traced back to 1775 when the London surgeon Pott attributed the common occurrence of scrotum cancer in chimney sweeps to the prolonged exposure of skin to soot (6). In the beginning of the 20th 
century, Yamagawa and Ichikawa demonstrated the induction of skin carcinomas on rabbit ears by repeated topical applications of coal tar (7). In the 1930's, dibenzo(a,h)anthracene $(8)$ and $\mathrm{B}(\mathrm{a}) \mathrm{P}(9)$ were identified as highly carcinogenic constituents of coal tar. Important evidence that PAH-DNA binding plays a role in carcinogenesis was provided in 1964 by Brookes and Lawley (10), who demonstrated a correlation between the carcinogenic potency of six PAH and the extent to which they became covalently bound to DNA, but not to RNA or proteins. Miller and Miller (11) proposed that most carcinogens, including $\mathrm{PAH}$, are not active themselves, but require metabolic activation before they can interact with cellular macromolecules.

\subsection{Carcinogenicity of PAH in exposed rodents and humans}

\section{A. Exposure levels and routes}

The general population is exposed to $\mathrm{PAH}$ via three different routes; ingestion, inhalation and dermal absorption. PAH are found in substantial quantities in many foods, depending on their origin and the method of cooking, preservation and storage. High concentrations of PAH were found in charcoal broiled and smoked foods and also in leafy green vegetables $(4,12)$. PAH levels in the latter paralleled with the atmospheric burden, indicating that $\mathrm{PAH}$ are taken up or deposited from the atmosphere (4). In the past, uptake of B[a]P via ingestion has been measured or estimated in several studies. However, large inconsistencies and discrepancies were found and still there is a lot of discussion about the accuracy of the estimated exposure levels (13). It was estimated that intake of $\mathrm{B}[\mathrm{a}] \mathrm{P}$ by ingestion varied between $0.03 \mu \mathrm{g} \mathrm{B}[\mathrm{a}] \mathrm{P} /$ day (14) and $2.2 \mu \mathrm{g}$ B[a]P/day (15). In the Netherlands, dietary intake of B[a]P was measured between 1984 and 1986, and was found to be approximately $100 \mathrm{ng} \mathrm{B}[\mathrm{a}] \mathrm{P}$ per day and dietary exposure to total PAH was estimated to be $6 \mu \mathrm{g} /$ day $(16,17)$.

Inhalatory exposure to PAH is well studied in the Netherlands; the mean concentration of $\mathrm{B}[\mathrm{a}] \mathrm{P}$ in air was found to be $0.5-0.6 \mathrm{ng} / \mathrm{m}^{3}$, with peakconcentrations up to $4 \mathrm{ng} / \mathrm{m}^{3}$ near certain factories, or even $70 \mathrm{ng} / \mathrm{m}^{3}$ in indoor air by the use of an open fireside (17). Assuming that adult humans inhale ca. $12 \mathrm{~m}^{3}$ air per day and the PAH deposition rate amounts to about $50 \%$, uptake of PAH by inhalation may theoretically result in $6 \mathrm{ng}$ and $420 \mathrm{ng}$ B[a]P per day for respectively clean ( $\left.<1 \mathrm{ng} \mathrm{B}[\mathrm{a}] \mathrm{P} / \mathrm{m}^{3}\right)$ and heavily polluted air $\left(70 \mathrm{ng} \mathrm{B}[\mathrm{a}] \mathrm{P} / \mathrm{m}^{3}\right)$. For comparison, the average total $\mathrm{B}[\mathrm{a}] \mathrm{P}$ content of mainstream smoke of one cigarette can vary between $20 \mathrm{ng}$ and $40 \mathrm{ng}$. A total human environmental exposure study on $\mathrm{B}[\mathrm{a}] \mathrm{P}$ examined all possible pathways of contact at one time (14). The results indicated that the PAH intake by food and by inhalation were equally important; dominance of one pathway or the other depended upon personal dietary habits and the indoor combustion source used.

Dermal uptake of PAH is of minor importance for the general population. However, under certain circumstances dermal exposure to PAH can be very high. For example, considerable PAH exposures were found in occupational settings, such as in the aluminum industry, in workers handling molten tar, pitch or asphalt 
(roofing, paving), chimney sweeps and foundry workers (18). A substantial part of the body may be exposed to PAH if clothes become contaminated. Another group of individuals with extremely high levels of exposure via dermal contact is represented by patients with skin diseases (e.g., psoriasis, eczema, dandruff or skin infections), who were treated with coal-tar containing ointments $(19,20)$. In a recent study, $B[a] P$ concentrations in coal-tar ointments were found to be higher than $1.5 \mathrm{mg} \mathrm{B}[\mathrm{a}] \mathrm{P} / \mathrm{kg}$ ointment (20). Thus, if a patient is treated with for example $100 \mathrm{~g}$ of ointment, the delivered total dose of B[a]P on the skin would be as high as $0.15 \mathrm{mg}$, a dose capable of inducing skin tumors in laboratory rodents (see next paragraph).

\section{B. Carcinogenicity in relation to exposure routes}

In animal experiments, carcinogenic PAH become effective predominantly at the site of application and the animal species investigated so far show very similar reactions (4).

In laboratory rodents, orally exposed to $\mathrm{B}[\mathrm{a}] \mathrm{P}$, tumors of the esophagus and forestomach were observed (21). Although absorption of lipophilic B[a]P after oral application is normally hampered by the mucous layer of the gastrointestinal tract, $\mathrm{B}[\mathrm{a}] \mathrm{P}$ penetrates quite easily the forestomach epithelium of mice, almost irrespective of the vehiculum used to administer the B[a]P. At higher doses, oral applications of $\mathrm{B}[\mathrm{a}] \mathrm{P}$ also induce systemic carcinogenic effects in various animal species. For example, in mice fed with a diet containing B $[\mathrm{a}] \mathrm{P}(250 \mu \mathrm{g} / \mathrm{g}$ of food), lung adenomas and leukemia's developed in addition to tumors of the forestomach (22). In some strains of rats, oral administration of B[a]P and related compounds very easily induced carcinomas of the mammary gland as well (23). It was even possible to induce skin papillomas in mice after a single gavage of $3 \mathrm{mg} \mathrm{B}[\mathrm{a}] \mathrm{P}$ and subsequent treatment of the skin with croton oil (24). PAH in our food may also exert a carcinogenic effect in the gastrointestinal tract of man. Indeed, the incidence of stomach cancer in 50 to 69 year-old subjects in an area of the USA with high air pollution was almost $100 \%$ higher as compared with areas with lower air pollution (25). However, this information is not sufficient to permit final conclusions.

Inhalatory exposure (or intratracheal instillation) of laboratory rodents to $\mathrm{B}[\mathrm{a}] \mathrm{P}$ predominantly resulted in the induction of lung tumors (21). PAH exposure of humans by inhalation is thought to be responsible, at least partly, for the higher lung cancer frequency in smokers than in non-smokers, in urban populations than in rural populations, and in some groups of workers compared with the general population. For example, epidemiological studies on gas, coke and aluminum workers, who are exposed to high concentrations of PAH in the ambient air, showed increased risks of respiratory cancers $(26,27)$. Furthermore, epidemiological data suggest that smoking tobacco is additionally related to cancer of the upper aerodigestive tract, pancreas, renal pelvis, bladder and cervix (28).

Studies in experimental animals treated topically with PAH or PAH containing mixtures, show clear evidence of local carcinogenicity (4). Evidence for skin carcinogenicity of PAH in humans has mainly come from studies on the frequency of cancer among workers exposed to coal-tar or soot (29). For instance, recent studies showed that skin cancer risks were significantly increased in road pavers and 
highway maintenance workers (28). The number of reports regarding coal-tar treated patients is surprisingly low. In fact, skin tumors induced by the therapeutic use of coal-tar are seldomly noticed in the clinical profession.

\subsection{PAH metabolism and DNA adduct formation}

PAH are lipid soluble and tend to accumulate in individuals who come into contact with them, unless they are metabolized to more water soluble derivatives that can be excreted in urine or faeces (3). Paradoxically, PAH would not be carcinogenic if they were not metabolized. The initial step in the metabolism of unsubstituted PAH is the formation of epoxides, the addition of an oxygen across a double bond, by cytochrome P450 dependent mono-oxygenases (31).

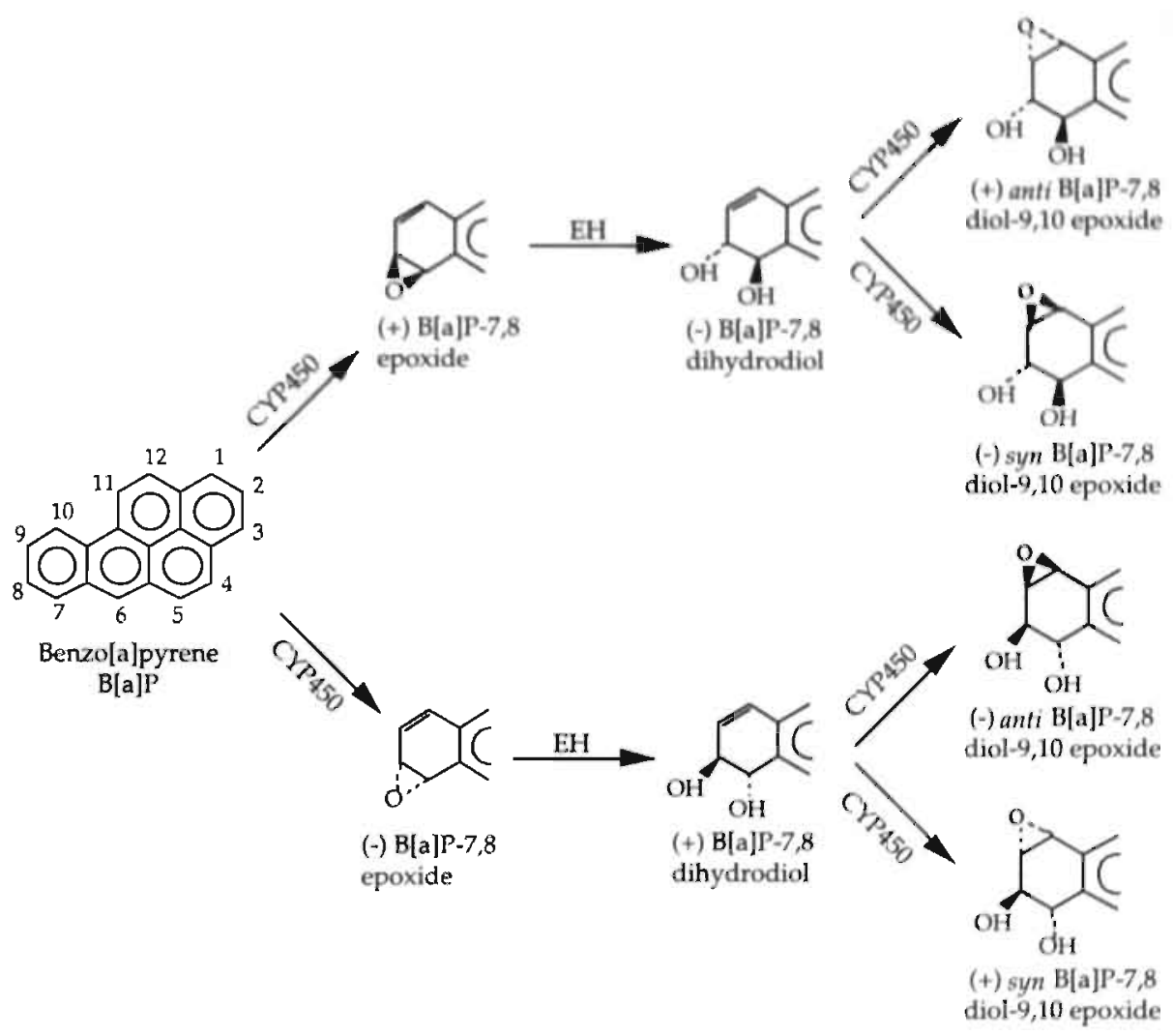

Figure 1. Stereoselective metabolism of B[a]P to BPDE via cytochrome P450 (CYP450) and epoxide hydrolase ( $\mathrm{EH}$ ) dependent reactions (adapted from reference 3 ).

Further metabolism results in hydration by epoxide-hydrolase to dihydrodiols; isomerization to phenols, or conjugation with glutathione by glutathione-Stransferases. Glutathione conjugated PAH are water soluble and can easily be 
excreted in faeces or urine as mercapturic acids (see Chapter 1.5). Phenols and dihydrodiols are conjugated with glucuronic acid or sulfuric acid by respectively glucuronyl-transferases, located in the endoplasmatic reticulum, and sulphotransferases which are cytosolic enzymes (3). As a result, predominantly water soluble derivatives are formed, but occasionally the enzyme system will activate the parent compound to biologically reactive forms, that are able to covalently bind to cellular macromolecules, such as protein, RNA and DNA.

Many studies have focused on the metabolic activation of B[a]P to certain reactive dihydrodiol epoxide derivatives (32). At first, B[a]P is metabolized by cytochrome P450 to B[a]P-7,8-epoxide, which exists as a pair of enantiomers (Figure 1). Subsequently, this epoxide is hydrated by epoxide-hydrolase, which results in two B $[$ a]P-dihydrodiols. The next step involves the addition of a second oxygen across the 9,10 double bond resulting in B[a]P-7,8-dihydrodiol-9,10-epoxide (BPDE), either as the syn- or anti-form (the epoxide oxygen on the same (syn) or the opposite (anti) face of the benzene ring as the hydroxyl group at the C7-position) (32). Epoxidation of the B[a]P-7,8-diol is also accomplished by non-cytochrome P450 mediated reactions. For example, peroxyl free radicals are capable of inserting oxygen atoms across the 9,10 double bond of the B[a]P-7,8-diol (33). The steps catalyzed by mono-oxygenases are highly stereoselective and the main metabolite appears to be (+)anti-BPDE, which has been found to possess greater biological activity than the other three metabolites $(3,34)$, and therefore most of the studies regarding the interaction of BPDE with DNA have been performed with this compound or in combination with its enantiomer ((+)anti-BPDE or (-)anti-BPDE).

The predominant adduct found in DNA or polyribonucleotides after exposure to (+)anti-BPDE is a covalent interaction product between the 2-amino group of guanine $\left(\mathrm{N}^{2}\right)$ and the $\mathrm{C} 10$-position of $\mathrm{B}[\mathrm{a}] \mathrm{P}(35$, Figure 2 ). This adduct is considered to be chemically stable. Several other interactions of dihydrodiol epoxides have been shown to occur, such as binding at the N7 position of guanine and the exocyclic amino groups of adenine and cytosine. Other PAH, such as 7,12dimethylbenzo(a)anthracene, benzo(a)anthracene, benzo(c)phenanthrene, chrysene, 5-methylchrysene, dibenzo(a,e)fluoranthene and dibenzo(a,h)anthracene, are also converted into reactive dihydrodiol epoxides that bind to DNA $(3,34)$. A unique structural feature of these diolepoxides is that the epoxide group is located in the bay-region of the molecule, formed by the presence of an angular benzene ring (36). The high chemical reactivity of bay-region diol epoxides can be attributed to the fact that they easily undergo ring opening to a carbonium ion while enzymatic detoxification by epoxide hydrolase is sterically obstructed. However, in such a structurally diverse group of compounds as $\mathrm{PAH}$, it is obvious that exceptions can not be excluded, but it is believed that the general mechanism of metabolic activation is by the formation of bay-region dihydrodiol epoxides.

$\mathrm{B}[\mathrm{a}] \mathrm{P}$ can also be activated via a one-electron oxidation pathway, which generates a radical cation $\left(\mathrm{B}[\mathrm{a}] \mathrm{P}^{\bullet+}\right)$ with the positive charge mainly localized at the C6 position of the molecule (37). This metabolic pathway can be catalyzed by various enzyme systems, such as cytochrome $\mathrm{P} 450$, prostaglandine- $\mathrm{H}$-synthetase and peroxidases (38), and may be of practical importance since certain target organs (e.g. 
lung and stomach) for $\mathrm{B}[\mathrm{a}] \mathrm{P}$ and other $\mathrm{PAH}$ are generally low in total cytochrome P450 concentrations, but have significant levels of prostaglandine-H-synthetase. The most potent $\mathrm{PAH}$ possess relatively low ionization potentials and are therefore easily metabolized via both the one electron-oxidation and via the diol-epoxide pathway. $\mathrm{B}[\mathrm{a}] \mathrm{P}$-radical cations predominantly form labile DNA adducts at the N7 position of guanine and adenine, which are lost by depurination and leave apurinic sites in the DNA (39). If not properly repaired,

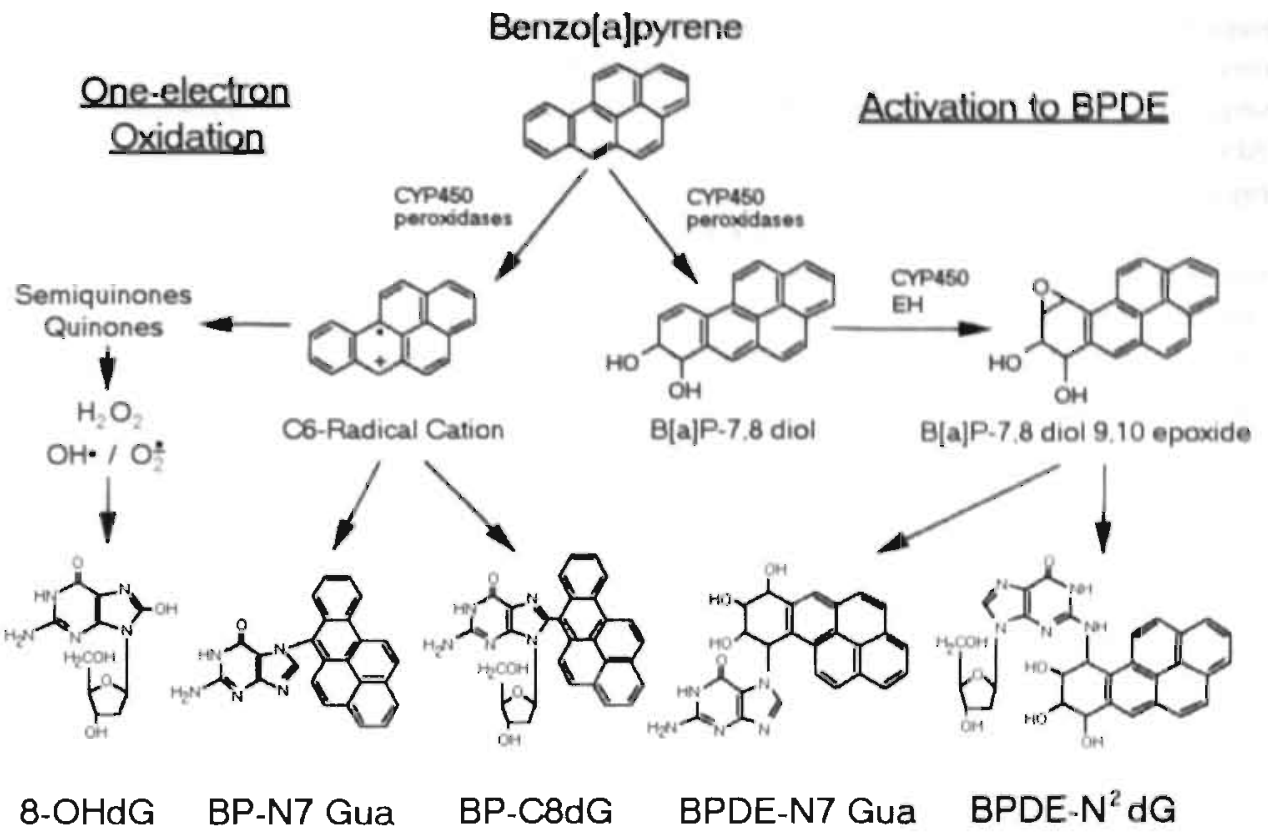

Figure 2. Schematic overview of the induction of DNA damage by B/a]P via various metabolic pathways. The left side of the figure represents the one-electron oxidation pathway, whereas the right? side of the figure represents the activation of B[a]P to bay-region diol epoxides.

these sites may induce mutations through mispairing (40). Analysis of DNA adducts in mouse skin treated with $\mathrm{B}[\mathrm{a}] \mathrm{P}$, showed that the one electron oxidation pathway may also induce some stable DNA adducts (41). Probably the B[a]P-6-C8deoxyguanosine is involved, since this adduct was found as stable DNA adlduct in in vitro studies (33, Figure 2).

Furthermore, the $\mathrm{B}[\mathrm{a}] \mathrm{P}$ radical cation functions as an intermediate metabrolite in the formation of $6-\mathrm{OH}-\mathrm{B}[\mathrm{a}] \mathrm{P}$, which is a labile phenol (37). Auto-oxidation of this derivative may ultimately result in the formation of $\mathrm{B}[\mathrm{a}] \mathrm{P}$ quinones. $\mathrm{B} \mid \mathrm{a}] \mathrm{P}$ quinones are almost invariably found after metabolism of $\mathrm{B}[\mathrm{a}] \mathrm{P}$, sometimes accounting for more than $50 \%$ of the total metabolic yield (42). The B[a]P quinones formed are 6,12 , 
1,6- and 3,6-B[a]P quinones, which can undergo redox-cycling to their corresponding $\mathrm{B}$ [a]P diols coupled with molecular oxygen to form superoxide and hydroxyl radicals by the Haber-Weiss and Fenton reactions (43). The hydroxyl radicals produced can give rise to oxidative DNA damage, e.g. 8-oxodeoxyguanosine (8-oxodG) formation and DNA single and double strand breakage.

\subsection{PAH-DNA adducts and their role in carcinogenesis}

Chemically induced carcinogenesis is a complex multistage process, which involves mutations in growth-regulatory proto-oncogenes (e.g. ras) and tumorsuppressor genes (e.g. p53) (2). The initial step is thought to be the interaction of electrophilic metabolites with DNA, which may result in a changed nucleotide sequence due to misincorporation of a nucleotide opposite the darnaged base. Aberrant gene products or modified gene expression may ultimately disrupt normal regulatory processes of cell growth.

There are several lines of evidence regarding the role of PA.H-DNA adducts in transformation of normal cells into cancerous cells. Firstly, experiments with cultured cells exposed in vitro to PAH. Secondly, studies using animal models, particularly laboratory rodents. Thirdly, studies in healthy human volunteers and cancer patients, who were exposed to $\mathrm{PAH}$.

\section{A. In Vitro Studies}

Important evidence for the promutagenic role of DNA adducts in marnmalian cells was provided by in vitro studies using shuttle vectors with DNA adducts at specific localization's (44). However, the best evidence for the role of PAH-DNA adducts in human cancer has emerged relatively recently in a study by Denissenko $e t$ al. (45). It was found that the strong and sequence-specific formation of BPDE-DNA adducts in $p 53$ of bronchial epithelial cells in vitro occurred at the same positions as the major mutational hotspots in $p 53$ found in DNA from human lung cancer tissue. Furthermore, other studies on cultured cells in vitro exposed to PAH, showed that aromatic carcinogens have the potential to alter or "activate" $\mathrm{H}$-ras proto-oncogenes (46-48). In these studies, the most predominant point mutations induced by BPDE were $G$ to $T$ transversions and to a lesser extent $G$ to $A$ transitions, similar to those found in ras oncogenes and p53 tumor suppressor genes in human cancers (49). Recent studies strongly suggest that both preferential adduct formation and slow repair lead to such mutational hotspots $(50)$.

\section{B. Studies in Laboratory Rodents}

Despite this convincing body of evidence supporting the critical role of DNA adducts in PAH-induced cancers, much remains to be uncovered about the quantitative relationship between PAH-DNA adduct formation and cancer risk in vivo. One might expect that higher concentrations of PAH-DNA adducts would imply a higher likelihood of critical mutations leading to cancer. However, studies with laboratory rodents have led to the understanding that there is no simple algorithm for translating DNA adduct levels into cancer risk. For example, DNA 
adducts appeared to be not specific for target organs, but are also formed in tissues in which no tumors are induced $(51,52)$. Thus, DNA adducts are not solely responsible for tissue specific cancers, but additional factors are involved. However, the overall data in target organs of animal models seem to point out that the level of DNA adducts is actually related to cancer risk. In some cases, but not all, the target organs of sensitive animal species had higher adduct levels than the same organs in resistant species (53).

Chronic administration of a carcinogen resulted in the attainment of steadystate DNA adduct levels, which were related to the dose over a wide range and were generally correlated with the carcinogenic outcome (54). Furthermore, inhibition of adduct formation resulted in decreased carcinogenicity of B[a]P (55). In studies concerning acute exposure to a single dose of a carcinogen, the relationship between DNA adducts and the carcinogenic outcome is more complex, because DNA adduct levels change as a function of time and may follow different pharmacokinetics for different carcinogens. Ross et al (56) showed that the adduct level integrated over time (i.e., area under curve) correlated with the induction of lung carcinoma by several PAH. This suggests that both formation and removal of PAH-DNA adducts determine their carcinogenic potency. This was also suggested in a study by De Vries et al. (57) in which knock-out mice deficient in nucleotide excision repair (NER) were orally exposed to B[a]P. In B[a]P exposed NER-deficient mice, an enhanced mutation frequency in lymphocytic cells was observed, which coincided with lymphomas residing in the spleen (57).

\section{Studies in Humans}

In humains, no prospective studies that directly link DNA adduct levels with cancer outcome have been performed yet. Many studies were on a cross-sectional basis, which may obscure the temporal relationship between exposure, DNA adduct formation and cancer (the presence of a tumor may affect DNA adduct levels). However, there is sufficient evidence to assume that DNA adducts are actually related to cancer risk in man. For example, Perera et al (58) reported a correlation between DNA adduct levels and the in vivo mutation frequency in individuals occupationally exposed to PAH. Although the gene (HPRT) and tissue (white blood cells, WBC) under investigation, are not relevant in occupationally related carcinogenesis, their results provide evidence for the mutational effects of PAH in vivo in humans. In general, aromatic-DNA adduct levels in critical organs and cancer risks are both related to PAH-exposure $(59,60)$. Moreover, correlations have been observed between DNA adduct levels in various groups of exposed subjects and their corresponding cancer risk. For instance, higher adduct levels were observed in lung of smoking females as compared with males (61), which is in line with epidemiological data showing that women are at a greater risk of tobacco-induced lung cancer $(62,63)$. Furthermore, higher PAH-DNA adduct levels in lung parenchyma (64) and peripheral blood leukocytes (65) were observed in lung cancer patients as compared with healthy controls. 
Thus, taken together all the available in vitro and in vivo data, it can be concluded that it is possible to use DNA adduct data to estimate human cancer risk, but also that this area of research clearly requires further attention.

\subsection{Susceptibility for PAH-DNA adduct formation}

\section{A. Detoxification of $\mathrm{PAH}$}

All living mammalian cells possess a certain capacity to cope with the presence of reactive $\mathrm{PAH}$-derivatives and to prevent formation or accumulation of DNA damage. Electrophilic metabolites may be detoxified by glutathione-S-transferases (GST's) before they might react with cellular macromolecules (3). GST's form an important group of enzymes involved in the nucleophilic addition of the tripeptide. glutathione (GSH) to lipophilic substrates that have electrophilic functional groups. The GST's can be divided into four classes, Alpha $(\alpha), \mathrm{Mu}(\mu)$, Theta $(\tau)$ and Pi $(\pi)$, based on structural and catalytic properties (66). The existence of a multiplicity of isoenzymes made the nomenclature very confusing; therefore, a new nomenclature was introduced and agreed upon by many of the principal workers in the field. The new designation of these dimeric proteins was based on an international system for human gene-nomenclature (67, shortly reviewed in ref. 66) and will be used in this thesis. For example, a dimeric GST-protein containing two subunits of the 1 -class is now designated as GSTM1-1, and the corresponding gene is designated GSTM1. Especialiy GSTM1-1 and GSTP1-1 seem to have a high affinity towards epoxides, and may thus play an important role in the protection against reactive PAH-diolepoxides. BPDE has a slow spontaneous rate of reaction with GSH. However, if this rate is sufficiently enhanced by GST-catalysis, the resulting reaction may compete effectively with DNA adduct formation (66). Interestingly, the expression of GST's is highly variable between different tissues and individuals. For example, about $50 \%$ of the Caucasian population lack the GSTM1 gene and has therefore no GSTM1-1 activity and it has been reported in molecular epidemiological studies that these individuals might have an increased risk for developing lung cancer (68). In some studies, the absence of the GSTM1-1 isoenzyme in lung of smoking individuals was associated with relatively high PAH-DNA adduct levels, which implies an important role of GSTM1 in scavenging reactive PAH-metabolites $(66,69-71)$. On the other hand, in a recent study by Schoket et al. (72) such a relationship was not found.

Other important PAH-detoxifying enzymes are UDP-glucuronosyl transferase (UGT) and sulfotransferase (ST), which catalyze the conjugation of PAH-derivatives that posses $-\mathrm{OH}$ functions with respectively glucoronic acid and sulfate (3). The dose-dependent conjugation of mainly quinones and phenol metabolites results in sufficiently hydrophilic compounds that can be excreted in urine or faeces. Genetic polymorphisms of glucuronidation and sulphation are known to exist (73), although the characterization and assessment of the importance of these variations are hampered by the lack of appropriate studies in humans with suitable and safe model compounds.

Human exposure to PAH via diet or cigarette smoke always coincides with exposure to other aromatic compounds, such as aromatic amines. Aromatic amines 
can be acetylated by N-acetyl transferases (NAT) and at least two genes are involved, NAT1 and NAT2 (74). Generally, $N$-acetylation of aromatic amines is considered to be a detoxifying mechanism, because it competes with $\mathrm{N}$-oxidation by cytochrome P450 1A2 which produces reactive hydroxylamines that can be further metabolized to DNA binding electrophiles. Approximately half of the Western population is slow acetylating (74), which was observed to be associated with high levels of DNA damage caused by aromatic amines (75) and a greater susceptibility to bladder cancer in smokers and occupationally exposed subjects (68). On the other hand, rapid acetylators seemed to have a higher risk for developing colorectal cancers $(68,76)$. The NAT polymorphisms seem to be more relevant at low exposures as compared to high levels of exposure, as suggested by the more pronounced effect of the NAT2polymorphism on 4-amino-biphenyl (=aromatic amine)-hemoglobine adducts in low as compared with heavy smokers (77).

\section{B. Activation of $P A H$}

Activities of other enzymes involved in the activation of PAH-metabolites are highly variable between individuals as well, and the basis for this variability is often a genetic polymorphism in genes that encode for these enzymes. For example, The gene that codes for the inducible cytochrome P450 (CYP) isoenzyme CYP1A1, which is characterized by affinity for planar substrates like PAH and its ability to oxygenate molecules in conformationally hindered positions (bay-regions), was found to be polymorphic in the $3^{\prime}$ noncoding region (78). A Mspl restriction site polymorphism seemed to be associated with an increased risk for lung cancer as initially reported by Kawajiri et al. (78). In another study, they postulated that the MspI polymorphism was genetically linked with an Isoleusine $\rightarrow$ Valine polymorphism in exon 7 , which is related to a stronger capacity of the enzyme to bind the substrate (79). In a Japanese population, individuals with the susceptible CYP1A1 MspI genotype combined with deficient GSTM1 had a remarkably high risk for developing carcinoma in lung $(\mathrm{OR}=16)$. The risk was even higher in individuals who had the exon 7 susceptible genotype of $\mathrm{CYP1A1}$ ( Val/ $\mathrm{Val}$ ) combined with the GSTM1 null genotype $(\mathrm{OR}=41)(80)$. So far, the number of reports supporting Kawajiri's first observation for populations outside Japan is limited $(68,81,82)$. The influence of the CYP1A1 polymorphism on DNA adduct levels in lung is still not clear; although most genotyping studies were unable to find a relationship between both parameters; recently Rojas et al. (71) found a clear effect of the combination of CYP1A1 and GSTM1 genotypes on the formation of specifically BPDE-DNA adducts in human lung and lymphocytes. A study involving phenotyping showed a clear correlation between aromatic-DNA adducts and CYP1A1 activity among smokers (83). Overall, it is thought that the balance between activation and inactivation of PAH may play a significant role in the susceptibility towards the formation of DNA adducts and subsequent risk for developing chemically induced cancers. Thus, it is expected that assessment of the complete set of putative 'high risk genotypes' will allow the identification of susceptible individuals or subgroups. Currently, however, investigating all genotypes that might be involved in the metabolism of complex chemical mixtures 
seems impossible and if biological responses (induced by DNA damage) are taken into account, the whole picture will be even more complex.

\section{P53 Accumulation and DNA repair}

An important biological response as a consequence of DNA damage is the accumulation of wild-type p53 tumor suppressor protein. Two functions have been proposed for p53 accumulation after DNA damage; induction of apoptosis and induction of pathways that arrest cells in the G1 phase of the cell-cycle to provide sufficient time for efficient DNA repair (84). Wild-type p53 protein is a sequence specific DNA binding protein, capable of binding to and regulating transcription of other genes that contain p53 responsive elements, like Gadd45, Mdm2 and p21 WAFI/CIP1, involved in cell-cycle regulation (85). P53 accumulates in mannmalian cells after exposure to various DNA damaging compounds, such as UV (86-88), $\gamma-$ rays $(89,90)$, bleomycin and actinomycin $\mathrm{D}(91)$, cisplatin, nucleotide analogues $(92$, 93) and BPDE (94). Thus, p53 accumulation may prevent the consequences of DNA adduct formation and the onset of carcinogenesis by selection in favor of efficiently repaired cells, against heavily damaged cells. The contribution of DNA repair in PAH-DNA adduct persistence is of relevance. In in vitro studies using BPDE or B[a]]P treated lymphocytes of healthy volunteers, a broad range in repair capacity was observed $(95,96)$. This range included individuals with an apparent complete lack of DNA repair of bulky DNA adducts. This interindividual variation was not due to differences in exposure or the extent of initial adduct formation, but rather reflected true differences in DNA repair capacities. In individuals with efficient DNA repair, most of the DNA adducts were removed within the first 24 hours after treatment. The importance of DNA repair in the inhibition of mutagenesis and carcinogenesis is especially illustrated by studies on DNA repair deficient animals (57) and the high incidence of cancer in individuals with DNA-repair defects, such as xeroderma pigmentosum, Bloom's syndrome and ataxia telangiectasia.

\subsection{Exposure monitoring}

Epidemiological studies that intended to evaluate the health risks of environmental agents are usually compromised by the lack of quantitative exposure data for individuals within exposed populations (97). The incorporation of measurements of physiological, cellular, subcellular and molecular events into epidemiological research (called molecular epidemiology), may be very useful in improving the precision of carcinogen exposure and health risk estimates. These measurements are refered to as biological markers or biomarkers. Biomarkers can be classified as markers of exposure, markers of effect and markers of susceptibility. Exposure marker analysis comprises the assessment of agents or their metabolites either in tissues, secreta, excreta or any combination of these, to evaluate exposure as compared with an appropriate reference. An effect marker is a measurable biochemical, physiological or other alteration within an organism that can be recognized as an established or potential health impairment or disease. Finally, a 
susceptibility marker is an indicator of an inherent or acquired limitation of an organism's ability to respond to the exposure to a specific xenobiotic agent (97).

\subsubsection{The Framework}

The former paragraphs can be summarized as shown in Figure 3, which forms the theoretical basis for molecular epidemiology and provides a broad

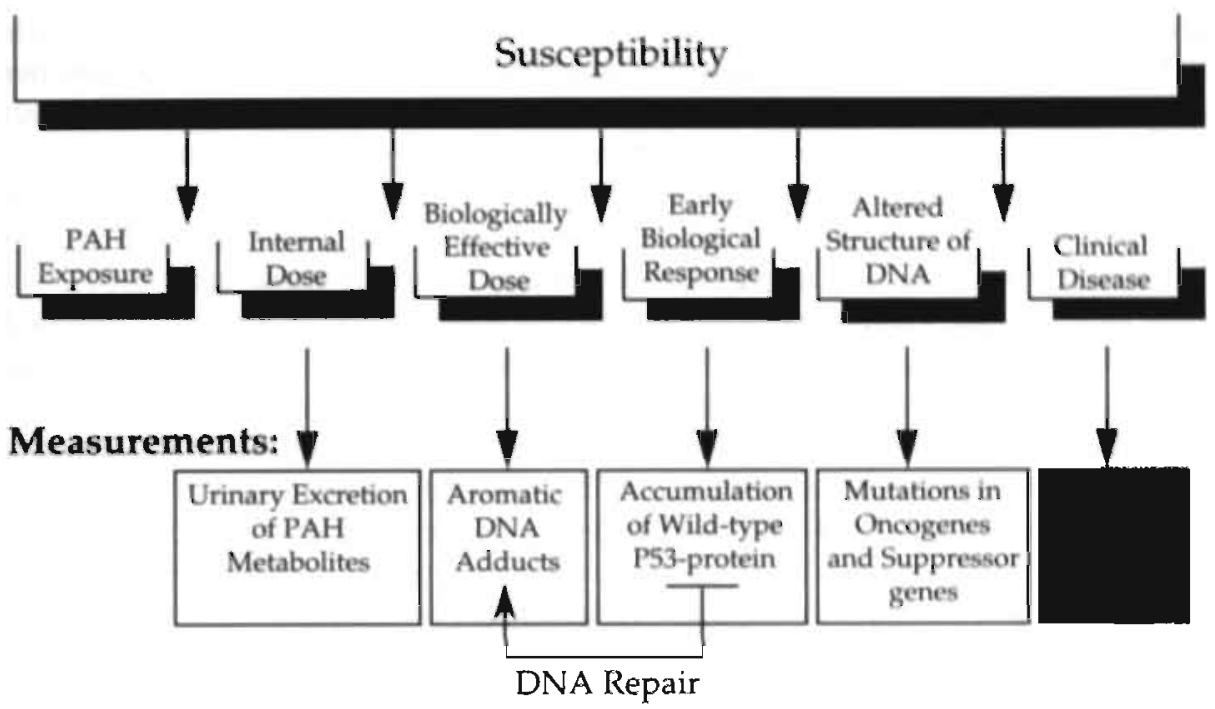

Figure 3. The frame work of molecular epidemiology, which provides a theoretical background for the application of biological markers as early end-points in cancer prevention studies.

range of possible biomarkers or measurements that might be of use in studies regarding PAH-exposure. For instance, the internal dose of PAH can be assessed by measuring PAH concentrations or PAH-metabolites in body fluids, of which urine is most commonly used (98). However, such measurements do not necessarily represent the biologically effective dose, which is the dose of a carcinogen that actually affects the DNA in a tissue in which ultimately tumors may occur (i.e., target organs, see Chapter 1.2). Therefore, the most promising biomarker seems to be the measurement of DNA adducts, since it takes into account individual differences in exposure, absorption and distribution of the chemical, its metabolism into DNA reactive forms, detoxification of reactive intermediates, as well as cell turnover and repair of DNA damage. However, for the effective use of DNA adducts in PAHexposure monitoring studies, several additional aspects of PAH.DNA adduct formation need to be known, which will be discussed in the next paragraphs. 


\subsubsection{Validity criteria for biological markers of exposure}

\section{A. Surrogate Tissues}

Practical and ethical considerations limit the types of tissues available for analysis of DNA adducts in man. Most target organs for PAH induced carcinogenesis can not be reached for routine sampling. Therefore, DNA adducts have predominantly been studied in easily available peripheral white blood cells (WBC). Gupta et al. (99) demonstrated the capacity of human peripheral blood lymphocytes to in vitro metabolize a number of carcinogens, including B[a]P, to their DNA binding species and high interindividual variations (up to 62 . fold) in binding capacity of reactive PAH derivatives were observed. This variation in B[a]P related DNA adduct formation in vitro was found to be genetically controlled (100) and may be indicative of individual differences in lung cancer susceptibility $(101,102)$. However, WBC are not necessarily target cells for PAH or the most sensitive cells for DNA adduct formation and the question remains whether these cells provide a reliable estimate of PAH exposure in vivo. Studies on occupationally exposed workers showed that, in general, adducts can be detected in a significant proportion of the exposed workers and to a lesser extent in control subjects (reviewed in ref. 103). Studies on smokers and nonsmokers showed conflicting results on the effect of smoking on PAH-DNA adduct levels in WBC. Several studies did not reveal any significant differences in PAH-DNA adduct levels between the two groups (104-106), suggesting that adducts in WBC may result from other sources than tobacco smoking. In a study among roofers, PAH-DNA adduct levels in WBC correlated with the amount of PAH in skin wipes, but not with the amount of $\mathrm{PAH}$ in personal air samples, indicating that dermal contact might be a major route for DNA adduct formation in WBC (107). Furthermore, several studies showed that the consumption of PAH-containing foods significantly enhanced DNA adduct levels in peripheral blood lymphocytes (108-110). The possibility for multiple routes of exposure may also complicate the relationship between adduct levels in target tissues and suT̃ogate tissues. For example, Phillips et al. (111) and Van Schooten et al. (112) did not find a clear relationship between DNA adduct levels in WBC and lung from lung cancer patients. However, more recent studies did find relationships between DNA adducts in potential target organs (lung and skin) and isolated peripheral blood lymphocytes $(20,113)$.

WBC can be subdivided in monocytes (5-10\% of total WBC), lymphocytes (20$40 \%$ ) and granulocytes (40-75\%). The life-span of lymphocytes varies from a few days to several years and these cells are therefore potentially useful in determining long-term exposure. On the other hand, the half-life of monocytes and granulocytes is much shorter (hours-days) and therefore DNA adducts in these cells may represent recent exposure only. The variable life-span of WBC-subsets makes the number of adducts persisting in total WBC after a given amount of time extremely uncertain; any immune-disturbance, like a common cold, may profoundly affect numbers and life-span of WBC subtypes. Furthermore, it has been observed that the various WBC-subpopulations differ in metabolic and repair capacities $(114,115)$. Thus, separation of the different WBC-subpopulations might be necessary to obtain a 
more reliable estimate of DNA adduct levels. Indeed, studies using isolated lymphocytes, monocytes or mononucleated blood cells (i.e., monocytes plus lymphocytes, MNC) showed clear differences between smoking and nonsmoking individuals $(113,116)$.

Other kinds of surrogate tissues have been used in the assessment of PAH exposure. Izotti et al., (117) and De Flora et al. (118) suggested that cells obtained by broncho-alveolar lavage (BAL) can be used as source of exposed DNA, specifically for inhaled carcinogens. The predominant cell-type in BAL is alveolar macrophages (AM), which can be considered as a nonperipheral WBC-subfraction, since these cells are thought to originate from peripheral blood monocytes that have left the circulation by passing through the walls of the alveolar capillaries.

Still, it is not clear which of these subtypes is/are the most reliable surrogate for assessing exposure to PAH and may serve as a molecular index for aromatic-DNA adduct formation in more remote tissues, like lung. Therefore, these cell-types should be compared with one another in the same study. This aspect, related to the routes of exposure, is described in this thesis. Furthermore, we should keep in mind that the applicability of surrogate tissues in field studies largely depends on their accessibility, and therefore the WBC-subpopulations seem to have the advantage above BAL-cells, but recent developments made it possible to use 'sputum induction' to obtain alveolar macrophages via an easy and relatively noninvasive procedure (119).

\section{B. Defined Pharmacokinetics and Temporal Relevance}

Knowledge on dose-response relationships and adduct persistence is inexpendable for exposure monitoring studies, which use DNA adduct levels as endpoints (97). For example, researchers should know how, and how fast adduct levels might change upon changes in exposure. Thus, understanding the kinetics of DNA adducts in surrogate and target tissues will guide the interpretation of adduct data in humans and is important in designing future studies for choosing the frequency and timing of sampling (97). The dose-response relationship between PAH-exposure and subsequent DNA adduct formation should be studied to evaluate the strenght of DNA adduct measurements to distinguish between two or more different exposure levels. In laboratory rodents exposed to low doses of PAH, adduct formation seemed to follow first-order kinetics, i.e. the degree of binding in target organs is proportional to the administered dose. However, human data on adduct formation do not demonstrate a strong proportional relationship between exposure and adduct levels (120-122). In lung tissue of smokers, a correlation was found between DNA adduct levels and the amount of cigarettes smoked per day (59), but further studies are necessary to determine the course of the dose-response relationship in WBC (subpopulations), which is studied in this thesis.

PAH-DNA adduct measurements should have the ability to integrate exposure to PAH over a relatively long (a few weeks up to a few months) period of time and also detect previous exposures after a long period of nonexposure. In lung tissue, DNA adduct levels were found to decrease after smoking cessation (72, 123-125). Removal of aromatic-DNA adducts from lung tissue apparently occurred in two 
phases; an initial fast reduction of DNA adduct levels, which is followed by a period in which adduct elimination is much slower. Studies in mice, suggest that adduct loss in lung is largely due to cell turnover (126). The persistence of PAH-DNA adducts in blood lymphocytes was studied by Mooney et al. (127). After 8 months of smoking cessation, a significant reduction of PAH-DNA adduct levels was found. Nonetheless, the characterization of elimination curves of aromatic DNA adducts in WBC needs further attention and therefore this aspect of adduct formation is further elucidated in this thesis.

\section{Lnderstanding inter- and intra-individual variability}

Inter- and intra-individual variations should be characterized before PAH. DNA adducts can be applied as exposure marker in large scale studies (97). It is known that DNA adduct formation is subject to a greater variability than external exposure assessment, because the body actively participates in the absorption, distribution, and elimination of PAH. In other words: two individuals with a similar level of external exposure, might have different aromatic-DNA adduct levels. As already mentioned, variations may be due to differences in metabolic phenotypes, possibly related to genetic polymorphisms in a variety of enzymes involved in the activation or detoxification of PAH (Chapter 1.5) or repair of PAH-DNA addlucts. Furthermore, possible confounders must be taken into account including age, sex, diet and race. Since the variation in adduct formation within or between individuals can be high, the question remains whether aromatic-DNA adduct levels in WBC can be applied to discriminate between individuals in various exposure or risk groups. Such discrimination is practically possible only if the inter-individual variation is not overshadowed by intra-individual variations or uncertainties in laboratory measurements, since these two factors are putatively unrelated to the exposure level or cancer risk (128). Thus, the observed range in DNA adducts in WBC is related to three factors: interperson variability, intra-individual variation and measurement uncertainty. Unfortunately, only few studies focused on intra-individual variations in DNA adduct formation in WBC (128), and several sources of inter-individual variation need more study.

\section{Comparison with other markers of PAH-exposure}

Several kinds of biomarkers, or combinations of these, have been used to assess exposure to PAH. Comparing one potential biomarker to another can provide useful information on marker characteristics, but does not constitute validation (97). In occupational settings (e.g. road-pavers, coke-oven workers and employees in the aluminum industry) the urinary excretion of hydroxylated PAH is considered to be the 'golden standard' for exposure assessment (reviewed in ref. 98, 129). However, hydroxylated $\mathrm{PAH}$-metabolites in urine can only be used to asses the internal dose after recent exposure to PAH. PAH metabolites that have been detected in human urine include 1-hydroxypyrene, 1-hydroxypyrene-O-glucuronide, 3-hydroxybenzo[a]pyrene and 7,8,9,10-tetrahydroxybenzo[a]pyrene. The most widely used analysis of these is 1-hydroxypyrene-O-glucuronide, which is often measured as 1hydroxypyrene after deconjugation of the glucuronide by $\beta$-glucuronidase (129). 
Studies regarding these urinary metabolites have been performed in occupational settings, but also in smokers, individuals that consumed charbroiled meat and eczema or psoriasis patients topically treated with coal-tar ointments $(20,98)$. Although the measurement of these metabolites is useful in assessing recent exposure, it does not represent the biologically effective dose. A limited number of studies have examined the association between urinary $\mathrm{PAH}$-metabolite concentrations and DNA adduct levels (20,130-132). However, the results were not consistent, which was probably due to differences in periods and timing of the collection of urine and sampling of blood. Further research on the comparison of both parameters is necessary.

\subsection{Aim and outline of this thesis}

In weighing the advantages and disadvantages of biological and environmental monitoring to define exposure, it is clear that DNA adduct measurements have at least three theoretical advantages over traditional exposure assessment. Firstly, they can smooth the extreme variability in exposure which is typical for environmental toxicants and therefore reduce the monitoring effort. Secondly, biological monitoring of DNA adducts in WBC accounts for all routes, i.e. inhalation, ingestion and dermai absorption. Finally, DNA adducts may account for interindividual differences in uptake, elimination, distribution, metabolism and repair amongst exposed individuals. On the other hand, sampling and analytical demands as well as the imprecision of assays may lead to significant measurement errors, which will tend to attenuate the underlying relationships. Furthermore, the interpretation of DNA adduct data in the context of exposure-response relationships is sometimes limited. Therefore, the aim of the present thesis is the evaluation of DNA adduct assessment in various surrogate tissues as measure for exposure to polycyclic aromatic compounds, using the validity criteria for biological markers of exposure as mentioned in Chapter 1.6 (Table 1).

Chapter 2: A comparison was made between several sources of surrogate tissues in smoking individuals, and in in vitro exposed WBC-subpopulations of nonsmoking volunteers. Chapter 3: The relationship between the level of exposure and DNA adduct levels was studied in MNC and BAL cells of smoking individuals and in WBC of occupationally exposed aluminum workers. In the same study, the intraindividual variation was assessed in smoking individuals over a period of 2 or 6 months. Chapter 4: The impact of different exposure routes on the relationship between DNA adduct formation in WBC and target organs was studied in rats acutely exposed to B[a]P. Chapter 5 : The persistence of smoking related aromaticDNA adducts in MNC was investigated in individuals who stopped smoking for a period of 6 months. In the same study, the effect of confounding variables such as age, sex and body composition on the dose-response relationship was investigated to obtain further insights in sources of inter-individual variation. Chapter 6: Interindividual variation is thought to corne, at least partly, from genetic polymorphisms in genes that encode for enzymes involved in PAH-metabolism. The impact of 
GSTM1 and NAT2 polymorphisms on aromatic-DNA adduct levels in MNC of current smokers was studied. Chapter 7: DNA adduct formation was studied in WBC subpopulations and skin of atopic eczema patients topically treated with coal-tar ointments, to obtain more information regarding the relationship between DNA adducts in surrogate tissues and a potential target tissue in humans. Additionally, urinary excretion of PAH-metabolites was studied to assess the whole PAH-body burden. Chapter 8: In the same eczema patients, the relationship between DNA damage and the accumulation of wild-type P53 in the basal layer of the epidermis was studied. Chapter 9. Exposure to B[a]P may generate reactive oxygen species. In this chapter the formation and repair of oxidative DNA damage was studied after acute oral exposure of rats to B[a]P. Chapter 10 and 11. Some technical aspects in DNA adduct analysis are discussed in these chapters. The focus will be on the quantitative assessment and identification of specifically BPDE-DNA adducts. Ultimately, all studies are summarized and discussed in chapter 12 . 
Table 1. Outline of this thesis in relation to the validity criteria for biological markers of exposure to $\mathrm{PAH}$ as mentioned in Chapter 1.6. The first column represents the subject of research; the second column indicates the chapter(s) in which this subject is described; The third and fourth column indicate which study-populations and corresponding samples were used, respectively.

Criteria Chapter Study-population(s) Samples

\begin{tabular}{|c|c|c|c|}
\hline $\begin{array}{l}\text { Comparison of } \\
\text { Surrogate Tissues }\end{array}$ & 2 & $\begin{array}{l}\text { Smokers } \\
\text { In vitro }\end{array}$ & $\begin{array}{l}\text { WBC, MNC, BAL } \\
\text { WBC-Subsets }\end{array}$ \\
\hline $\begin{array}{l}\text { Dose-Response } \\
\text { Relationships }\end{array}$ & $2,3,5,6$ & $\begin{array}{l}\text { Smokers } \\
\text { Aluminum Workers }\end{array}$ & WBC, MNC, BAL \\
\hline $\begin{array}{l}\text { Impact of } \\
\text { Exposure Route }\end{array}$ & 4 & Animal-model (rats) & WBC, Lung, Skin \\
\hline Adduct Persistence & 5 & Smokers & MNC \\
\hline $\begin{array}{l}\text { Intra-individual } \\
\text { Variation }\end{array}$ & 3 & Smokers & MNC, BAL \\
\hline $\begin{array}{l}\text { Interindividual } \\
\text { Variation }\end{array}$ & 5,6 & Smokers & MNC, BAL. \\
\hline Surrogate vs. Target & 4,7 & $\begin{array}{l}\text { Animal-model (rats) } \\
\text { Atopic Eczema Patients }\end{array}$ & $\begin{array}{l}\text { WBC, Lung, Skin } \\
\text { Stomach } \\
\text { WBC-Subsets } \\
\text { Skin }\end{array}$ \\
\hline $\begin{array}{l}\text { Early Biological } \\
\text { response }\end{array}$ & 8 & $\begin{array}{l}\text { Atopic Eczema Patients Skin } \\
\text { In vitro }\end{array}$ & MNC \\
\hline $\begin{array}{l}\text { Other Biomarkers of } \\
\text { PAH exposure }\end{array}$ & $4,7,9$ & $\begin{array}{l}\text { Animal model (rats) } \\
\text { Atopic Eczema Patients }\end{array}$ & $\begin{array}{l}\text { Lung, Liver, Heart } \\
\text { Urine }\end{array}$ \\
\hline $\begin{array}{l}\text { Technical Aspects in } \\
\text { DNA adduct analysis }\end{array}$ & 10,11 & $\begin{array}{l}\text { In vitro } \\
\text { Animal model (rats) }\end{array}$ & $\begin{array}{l}\text { MNC } \\
\text { Liver, Lung, Heart. }\end{array}$ \\
\hline
\end{tabular}

MNC, mononuclear ceils; WBC, total white blood cells; BAL, cells obtained by broncho-alveolar lavages.

\section{References}

1. Watson, J.D. and Crick, F.H.C. (1953) Molecular structure of nucleic acids: A structure for deoxyribose Nucleic Acid, Nature, 171,737

2. Pitot, H.C. (1990) Mechanisms of chemical carcinogenesis: theoretical and experimental bases. In: Cooper, C.S., Grover, P.L. (eds) Chemical Carcinogenesis and Mutagenesis, Vol. I, pp 3-32, New York, USA, Raven Press.

3. Hall, M., Grover, P.L. (1990) Polycyclic aromatic hydrocarbons: metabolism, activation and tumour initiation. In: Cooper, C.S., Grover, P.L. (eds) Chemical Carcinogenesis and Mutagenesis, Vol. I, pp 327-372, New York, USA, Raven Press. 
4. Grimmer, G. (1983) Environmental Carcinogens: polycyclic aromatic hydrocarbons. Boca Raton, USA, CRC press.

5. International Agency for research on Cancer (1983) Polynuclear Aromatic Compounds. Part I. Chemical, Environment and Experimental Data. IARC Monographs, Vol. 32, Lyon, France, International Agency for Research on cancer.

6. Pott, P. (1775) Chirurgical observations relative to the cataract, the polypus of the nose, the cancer of the scrotum, the different kinds of ruptures, and the mortification of the toes and feet. Hawes, Clarke, and Colins, London, UK.

7. Yamagiwa, K., and Ichikawa, K. (1915) Verh. jap. Path. Ges, 5, 142-148.

8. Kennaway, E.L., and Hieger, I. (1930) Br. I. Med., II, 1044-1046.

9. Cook, J.W., Hewett, C.L., Hieger, I. (1933) The isolation of a cancer producing hydrocarbon from coal-tar. I. Chem. Soc. 396-405

10. Brookes, P. and Lawley, P.D. (1964) Evidence for the binding of polynuclear aromatic hydrocarbons to the nucleic acids of mouse skin: relation between carcinogenic power of hydrocarbons and their binding to deoxyribosenucleic acid. Nature, 202, 781-784.

11. Miller, J.A. and Miller, E.C. (1969) The metabolic activation of carcinogenic aromatic amines and amides. Prog. Exp. Tumor Res., 11, 273-301.

12. Grasso P. (1984) Carcinogens in Food. In: Searle, C.E. (ed) Chemical Carcinogens. Washington D.C., USA, Am. Chem. Soc, Vol. 2, Second edition, pp 1203-1239.

13. Discussion between Lioy, P.J. and Hattemer-Frey, H.A, Travis, C. C.(1992). Toxicol. Ind. Health, 8, 213-219.

14. Lioy, P.L., Harkov, R., Waldman, J.M., Pietarinen, C., Greenberg, A. (1988) The total human environmental exposure study (THEES) to benzo[a]pyrene: comparison of the inhalation and food pathways. Arch. Environ. Health, 43, 304-312.

15. Hattemer-Frey, H.A., Travis, C.C. (1991) Benzo[a]pyrene: environmental partitioning and human exposure. Toxicol. Ind. Health, 7, 141-157.

16. Vaessen, H.M.G., Jekel, A.A., Wilbers, A.A.M.M. (1988) Dietary intake of polycyclic aromatic hydrocarbons. Toxicol. Environ. Chem. 16, 281-294.

17. Sloof, W., Janus, J.A., Matthijsen, A.J.C.M., Montizaan, G.K., Ros, J.P.M. (1989) Integrated criteria document PAHs (Basisdocument PAK), in Dutch. Bilthoven: National Institute of Public Health and Environmental Protection(RIVM) reportnr: 758474007.

18. Lindstedt, G. and Sollenberg, J. (1982) Polycyclic aromatic hydrocarbons in the occupational work environment. Scand. I. Work Environ. Health, 8, 1-19.

19. Pion, I.A., Koenig, K.L., Lim, H.W. (1995) Is dermatologic usage of coal-tar carcinogenic. Dermatol. Surg., 21, 227-231.

20. Godschalk, R.W.L., Ostertag, J.U., Moonen, E.J.C., Neumann, H.A.M., Kleinjans, J.C.S., Van Schooten, F.J. (1998) Aromatic DNA adducts in human white blood cells and skin after dermal application of coal tar. Cancer Epidemiol. Biomarkers \& Prev. 7, 767-773.

21. Soderman, J.V. (1985) CRC handbook of identified carcinogens and noncarcinogens, Vol. I, Chemical Class File, Boca Raton, USA, CRC-press.

22. Neal, J. and Rigdon, R.H. (1967) Gastric tumours in mice fed benzo[a]pyrene: a quantitative study. Tex. Rep. Biol. Med. 25, 553.

23. Huggins, C.H., and Yang, N.C. (1962) Induction and extinction of mammary cancer, Science, 137, 257.

24. Berenblum, I. and Haran-Ghera, N. (1957) The induction of the initiating phase of skin carcinogenesis in the mouse by oral administration of 9,10-dimethyl-1,2benzanthracene, 20-methylcholanthrene, 3,4-benzo[a]pyrene and 1,2,5,6dibenzanthracene: Br. I. Cancer. 11, 85.

25. Winkelstein, W. and Kantor, S. (1969) Stomach cancer. positive association with suspended particulate air pollution. Arch. Environ. Health, 18, 544.

26. Costantino, J.P., Redmond, C.K., Bearden, A. (1995) Occupationally related cancer risk among coke oven workers: 30 years of follow up. I Occup Environ Med, 37, 597-604.

27. Ronneberg, A., Andersen, A. (1995) Mortality and cancer morbidity in workers from an aluminium smelter with prebaked carbon anodes Part II. Occup Environ Med, 52, 250254. 
28. International Agency for Research on Cancer (1986) Tobacco Smoking. LARC monograph Vol 38. Lyon, France: International Agency for Research on Cancer.

29. International Agency for Research on Cancer (1984) Polynuclear Aromatic Compounds. Part 3. Industrial exposures in aluminum production, coal gasification, coke production, and iron and steel founding. IARC monograph. Vol 34. Lyon, France: International Agency for Research on Cancer.

30. Partanen, T. and Boffetta, P. (1994) Cancer risk in asphalt workers and roofers: review and meta-analysis of epidemiological studies. Am I Ind Med, 26, 721-740.

31. Nebert, D.W., and Gonzalez, F.J. (1987) P-450 genes: structure, evolution and regulation. Ann. Rev. Biochem. 56, 945-993.

32. Sims, P., Grover, P.L., Swaisland, A., Pal, K., and Hewer, A. (1974) Metabolic activation of $\mathrm{B}(\mathrm{a}) \mathrm{P}$ proceeds by a diol-epoxide. Nature, 252, 326-328.

33. Rogan, E.H., Cavalieri, S.R., Tibbels, S.R., Cremonesi, P., Warner, C.D., Nagel, D.J., Tomer, K.B., Cerny, R.L., Gross, M.L. (1988) Synthesis and identification of benzo(a)pyrene-guanine nucleoside adducts formed by electrochemical oxidation and by horseradish peroxidase catalyzed reaction of benzo(a)pyrene with DNA. I. Am. Chem. Soc. 110: 4023-4029.

34. Dipple, A., Moschel, R.C., Bigger, C.A.H. (1984) Polynuclear aromatic hydrocarbons. In: Searle (ed.) Chemical carcinogens. Washington D.C., USA, Am. Chem. Soc., Vol. 1, second edition, pp 41-163.

35. Weinstein, I.B., Jeffrey, A.M., Jennette, K.W., Blobstein, S.H., Harvey, R.G., Harris, C.C., Autrup, H., Kasai, H., and Nakanishi, K. (1976) Benzo(a)pyrene diol epoxides as intermediates in nucleic acid binding in vitro and in vivo. Science, 193, 592.

36. Jerina, D.M. and Daly, J.W. (1977) Oxidation at carbon. In: Parke, D.V. and Smith, R.L. (eds.) Drug metabolism- from microbe to man, London, UK, Taylor and Francis, pp. 1322.

37. Cavalieri, E., Rogan, E., Cremonesi, P., and Devanesan, P.D. (1988) Radical cations as precursors in the metabolic formation of quinones from benzo(a)pyrene and 6fluorobenzo(a)pyrene. Biochem. Pharmacol. 37, 2173-2183.

38. Cavalieri, E.L., Prabhakar, D., Devanesan, D., Rogan, E.H. (1988) Radical cations in the horseradish peroxidase and prostaglandin $H$ synthase mediated metabolism and binding of benzo(a)pyrene to deoxyribonucleic acid. Biochem. Pharmacol. 37, 21832187.

39. Rogan, E.H., Ramakrishna, N.V.S., Higginbotham, S., Cavalieri, E.L., Jeong. H., Jankowiak, R., Small, G.J. (1990) Identification and quantitation of 7-(benzo(a)pyren-6yl)-guanine in the urine and feces of rats treated with benzo[a]pyrene. Chem. Res: Toxicol. 3, 441-444.

40. Schaaper , R.M., Kunkel, T.A., Loeb, L.A. (1983) Infidelity of DNA synthesis associated with bypass of apurinic sites. Proc. Natl. Acad. Sci. 80, 487-491.

41. Bodell, W.J., Devanesan, P.D., Rogan, E.H., Cavalieri, E.L. (1989) 32.P.postlabeling analysis of benzo[a]pyrene-DNA adducts formed in vitro and in vivo. Chem. Res. Toxicol., 2, 312-315.

42. Wang, I., Rasmussen, R., Crocker, T. (1974), Life Sci., 15, 1291.

43. Lourentzen, R.J., and Tso, P.O.P. (1977) Benzo(a)pyrenedione/Benzo(a)pyrenediol oxidation-reduction couples and the generation of reactive reduced molecular oxygen. Biochemistry, 16, 1467-1473.

44. Hemminki, K. (1993) DNA adducts, mutations and cancer. Carcinogenesis, 14, 20072012.

45. Dennisenko, M.F., Pao, A., Tang, M., Pfeifer, G.P. (1996) Preferential formation of benzo[a]pyrene adducts at lung cancer mutational hotspots in P53. Science, 18, 430-432.

46. Marshall, C.J., Vousden, K.H., Phillips, D.H. (1984) Activation of c-H-ras-1 protooncogene by in vitro modification with a chemical carcinogen, benzo[a]pyrene-diol epoxide. Nature, 310, 586-589.

47. Vousden, K.H., Bos, J.L., Marshall, C.J., Phillips, D.H. (1986) Mutations activating human c-Ha-ras 1 protooncogene (HRAS1) induced by chemical carcinogens and depurination. Proc. Natl. Acad. Sci., 83, 1222-1226. 
48. Yang, J-L., Maher, V.M., McCormick, J.J. (1987) Kinds of mutations formed when a shuttle vector containing adducts of $( \pm)-7 \beta, 8 \alpha$-dihydroxy- $9 \alpha, 10 \alpha$-epoxy-7,8,9,10tetrahydrobenzo[a]pyrene replicates in human cells. Proc. Natl. Acad. Sci. 84, 37873791.

49. Vineis, P., Caporaso, N. (1995) Tobacco and cancer: Epidemiology and the laboratory. Environ. Health Perspect. 103, 156-160.

50. Denissenko, M.F., Pao, A., Pfeifer, G.P., Tang, M. (1998) Slow repair of bulky DNA adducts along the nontranscribed strand of the human p53 gene may explain the strand bias of transversion mutations in cancer. Oncogene, 16, 1241-1247.

51. Ross, J., Nelson, G., Kligerman, A., Erexson, G., Bryant, M., Earley, K., Gupta, R., Nesnow S. (1990) Formation and persistence of novel B(a)P adducts in rat lung, liver, and peripheral blood lymphocyte DNA. Cancer Res., 50: 5088-5094.

52. Godschalk, R.W.L., Vermeer, I.T.M., Kriek, E., Floot, B., Schilderman, P.A.E.L., Moonen, E.J.C., Kleinjans, J.C.S., Van Schooten, F.J. (1997) Comparison of 32Ppostlabeling and HPLC-FD analysis of DNA adducts in rats acutely exposed to benzo[a]pyrene. Chem. Biol. Inter.. 104, 41-54.

53. Wogan, G.N., and Gorelick, N.J. (1985) Chemical and biochemical dosimetry of exposure to genotoxic chemicals. Environ. Health Perspect, 62, 5-18.

54. Poirier, M., Beland, F.A. (1992) DNA adduct measurements and tumour incidence during chronic carcinogen exposure in animal models:implications for DNA adduct based human cancer risk assesment, Chem. Res. Toxicol., 5, 749-755.

55. Huang, M.-T., Wang, Z.Y., Georgiadis, C.A., Laskin, J.D., Conney, A.H. (1992) Inhibitory effects of curcumin on tumor initiation by benzo[a]pyrene and 7,12dimethylbenz[a]anthracene. Carcinogenesis, 13, 2183-2186.

56. Ross, J.A., Nelson, G.B., Wilson, K.H., Rabinowitz, J.R., Galati, A., Stoner, G.D., Nesnow, S., Mass, M.J. (1995) Adenomas induced by polycyclic aromatic hydrocarbons in strain A/J mouse lung correlate with time-integrated DNA adduct levels. Cancer Res., 55, 1039-1044.

57. De Vries, A., Dolle, M.E., Broekhof, J.L., Muller, J.J., Kroese, E.D., Van Kreijl, C.F., Vijg, J., Van Steeg, H. (1997) Induction of DNA adducts and mutations in spleen, liver and lung of X'PA-deficient/ LacZ transgenic mice after oral treatment with benzo[a]pyrene: correlation with tumour development. Carcinogenesis, 18, 2327-2332.

58. Perera, F.P., Dickey, C., santella, R., O'Neill, J.P., Albertini, R.J., Ottman, R., Tsai, W.Y., Mooney, L.A., Savela, K., Hemminki, K. (1994) Carcinogen-DNA adducts and genemutations in foundry workers with low-level exposure to polycyclic aromatic hydrocarbons. Carcinogenesis, 15, 2905-2910.

59. Phillips, D.H., Hewer, A., Martin, C.N., Garner, R.C., and King, M.M. (1988) Correlation of DNA adduct levels in human lung with cigarette smoking. Nature, 336, 790-792.

60. Cuzick, J., Routledge, M.N., Jenkins, D., and Gamer, R.C. (1990) DNA adducts in different tissues of smokers and non-smokers. Int. I. Cancer, 45, 673-678.

61. Ryberg, D., Hewer, A., Phillips, D.H., Haugen A. (1994) Different susceptibility to smoking-induced DNA damage among male and female lung cancer patients. Cancer Res., 54, 5801-5803.

62. Harris, R.E., Zang, E.A., Anderson, J.I., Wynder, E.L. (1993) Race and sex differences in lung cancer risk associated with cigarette smoking. Int. I. Epidemiol., 22, 592-599.

63. Risch, H.A., Howe, G.R., Jain, M., Burch, J.D., Holoway, E.J., Miller, A.B. (1993) Are female smokers at higher risk for lung cancer than male smokers? A case-control analysis by histological type. Am. I. Epidemiol. 138, 281-293.

64. Perera, F.P., Mayer, J., Jaretzki, A., hearnc, S., brenner, D., Young, T.L., Fischman, H.K., Grimes, M., Grantham, S., Tang, M.X. (1989) Comparison of DNA adducts and sister chromatid exchange in lung cancer cases and controls. Cancer Res. 49, 4446-4451.

65. Tang, D., Santella, R.M., Blackwood, A.M., Young, T.-L., Mayer, J., Jaretzki, A., Grantham, S., Tsai, W.-Y.. Perera, F.P. (1995) A molecular epidemiological case-control. study of lung cancer. Cancer Epidemiol. Biomarkers \& Prev., 4, 341-346.

66. Ketterer, B., Harris, J.M., Talaska, G., Meyer, D.J., Pemble, S.E., Taylor, J.B., Lang, N.P., Kadlubar, F.F. (1992) The human glutathione S-transferase supergene family, its. 
polymorphism and its effects on susceptibility to lung cancer. Environ. Health Perspect., 98, 87-94.

67. Shows, T.B., McAlpine, P.J., Bouchiex, C., Collins, F.S., Conneally, P.M., Frezal, J., gershowitz, H., Goodfellow, P.N., Hall, J.G., Issit, P., Jones, C.A., Knowles, B.B., Lewis, M., McKusick, V.A., Meisler, M., Morton, N.E., Rubinstein, P., Schanfield, M.S., Schnickel, R.D., Skolnick, M.H., Spence, M.A., Sutherland, G.R., Traver, M., Van Cong, N., Willard, H.F. (1987) Guidlines for human gene nomenclature. An international system for human gene nomenclature. Cytogenet. Cell Genet, 46, 11-18.

68. D'Errico, Taioli, E., Chen, X., Vineis, P. (1996) genetic metabolic polymorphisms and the risk of cancer: A review of the literature. Biomarkers, 1, 149-173.

69. Shields, P.G., Bowman, E.D., Harrington, A.M., Doan, V.T., Weston, A. (1993) Polycyclic aromatic hydrocarbon-DNA adducts in human lung and cancer susceptibility genes. Cancer Res, 53, 3486-3492.

70. Kato, S., Bowman, E.D., Harrington, A.M., Blomeke, B., Shields, P. (1995) Human lung carcinogen-DNA adduct levels mediated by genetic polymorphisms in vivo, I. Natl. Cancer Inst., 87, 902-907.

71. Rojas, M., Alexandrov, K., Cascorbi, I., Brockmöller, J., Likhachev, A., Pozharisski, K., Bouvier, G., Auburtin, G., Mayer, L., Kopp-Schneider, A., Roots, I., Bartsch, H. (1998) High Beno[a]pyrene diol-epoxide DNA adduct levels in lung and blood cells from individuals with combined CYP1A1 MspI/Mspl-GSTM1 $0 /{ }^{*} 0$ genotypes.

Pharmacogenet, 8, 109-118.

72. Schoket, B., Phillips, D.H., Kostic, S., Vincze, I. (1998) Smoking associated bulky DNA adducts in bronchial tissue related to CYP1A1 Mspl and GSTM1 genotypes in lung patients. Carcinogenesis, 19, 841-856.

73. Burchell, B., Coughtrie, M.W. (1997) Genetic and environmental factors associated with variation of human xenobiotic glucuronidation and sulfation. Environ. Health. Perspect, 105 Suppl., 739-747.

74. Shields, P.G. (1993) Inherited factors and environmental exposures in cancer risk. J. Occup. Med., 32, 34-41.

75. Vineis, P., Caporaso, N., Tannenbaum, S.R., Skipper, P.L., Glogowski, J., Bartsch, H., Coda, M., Talaska, G., Kadlubar, F.F. (1990) Acetylation phenotype, carcinogenheamoglobin adducts and cigarette smoking. Cancer Res., 50, 3002-3004.

76. Llett, K.F., David, B.M., Detchon, P., Castleden, W.M., Kwa, R. (1987) Acetylation phenotype in colorectal carcinoma. Cancer Res., 47, 1466-1469.

77. Vineis, P., Bartsch, H., Caporaso, N., Harrington, A.M., Kadlubar, F.F., Landi, M.T., Malaveille, C., Shields, P.G., Skipper, D., Talaska, G. (1994) Genetically based Nacetyltransferase metabolic polymorphism and low-level environmental exposure to carcinogens, Nature, 369, 154-156.

78. Kawajiri, K., Nakashi, K., Imai, K., Yoshii, A., Shinoda, N., Watanabe, J. (1990) Identification of genetically high risk individuals to lung cancer bt DNA polymorphisms of the cytochrome P4501A1 gene. FEBS Lett., 263, 131-133.

79. Hayashi, S.I., Watanabe, J., Nakashi, K. (1991) Genetic linkage of lung cancer associated MspI polymorphisms with amino acid replacement in the heme binding region of the human cytochrome P4501A1 gene. J. Biochem., 110, 407-411.

80. Nakashi, K., Imai, K., Hayashi, S., Kawajiri, K. (1993) Polymorphisms of the CYPIA1 and glutathione S-transferase genes associated with susceptibility to lung cancer in relation to cigartte dose in a Japanese population. Cancer Res., 53, 2994-2999.

81. Xu, X., Kelsey, K.T., Wiencke, J.K., Wain, J.C., Christiani, D.C. (1996) Cytochrome P4501A1 Mspl polymorphism and lung cancer susceptibility. Cancer Epidemiol. Biomarkers \& Prev., 5, 687-692.

82. Sigimura, H., Suzuki, I., Hamada, G.S., Iwase, T., Takahashi, T, Nagura, K., Iwata, H., Watanabe, S., Kino, I., Tsugane, S. (1994) Cytochrome P450 $1 A 7$ genotype in lung. cancer patients and controls in Rio de Janeiro, Brazil. Cancer Epidemiol. Biomarkers \& Prev. 3, 145-148.

83. Alexandrov, K., Rojas, M., Geneste, O., Castegnaro, M., Camus, A.M., Petruzelli, S., Giuntini, C., Bartsch, H. (1992) An improved fluoremetric assay for dosimetry of 
benzo[a]pyrene diol-epoxide DNA adducts in smoker's lung: comparison with total bulky adducts and aryl hydrocarbon hydroxylase activity. Cancer Res., 52, 6248-6253.

84. Lane, D.P. (1993) p53, guardian of the genome. Nature, 358, 15-16.

85. El-Deiry, W.S., Kern, S.E., Pietenpol, J.A., Kinzler, K.W., Vogelstein, B. (1992) Definition of a consensus binding site for p53. Nat. Genet. $1,45-49$.

86. Maltzman, W., Czyzyk, L. (1984) UV irradiation stimulates levels of p53 cellular tumor antigen in notransformed mouse cells. Mol. Cell. Biol., 4, 1689-1694.

87. Hall, P.A., McKee, P.H., du P. Menage, H., Dover, R., Lane, D.P. (1993) High levels of p53 protein in UV-irradiated normal human skin. Oncogene, 8, 203-207.

88. Yamaizumi, M., Sugano, T. (1994) UV-induced nuclear accumulation of p53 is evoked through DNA damage of actively transcribed genes independent of the cell-cycle. Oncogene, 9, 2775-2784.

89. Kastan, M.B., Onyekwere, O., Sidransky, D., Vogelstein, B., Craig, R.W. (1991) Participation of p53 protein in the cellular response to DNA damage. Cancer Res., 51, 6304-6311.

90. Zhan, Q., Bae, I., Kastan, M.B., Fornace, A.J. (1994) The p53 dependent $\gamma$-ray response of GADD45. Cancer Res., 54, 2755-2760.

91. Nelson, W.G., Kastan, M.B. (1994) DNA strand breaks: the DNA template alterations that trigger p53-dependent DNA damage response pathways. Mol. Cell. Biol., 14, 18151823.

92. Fritsche, M., Haessler, C., Brandner, G. (1993) Induction of nuclear accumulation of the tumor-suppressor protein p53 by DNA damaging agents. Oncogene, 8, 307-318.

93. Hess, R., Plaumann, B., Schulze-Lutum, A., Haessler, C., Heinz, B., Fritsche, M., Brandner, G. (1994) Nuclear accumulation of p53 in response to treatment with DNAdamaging agents. Toxicol. Lett., 72, 43-52.

94. Stierum, R.H., Van Herwijnen, M.H.M., Pasman, P.C., Hageman, G.J., Kleinjans, J.C.S., Van Agen, B. (1995) Inhibition of poly(ADP-ribose) polymerase increases ( \pm )-antibenzo[a]pyrene diol-epoxide induced micronuclei formation and p53 acumulation in isolated human peripheral blood lymphocytes. Carcinogenesis, 16, 2765-2771.

95. Stierum, R.H., Van Herwijnen, M.H.M., Maas, L.M., Hageman, G.J., Kleinjans, J.C.S. (1994) Measurment by ${ }^{32} \mathrm{P}$-postlabeling of $\left( \pm\right.$ )anti-benzo[a]pyrene diolepoxide- $\mathrm{N}^{2}$ deoxyguanosine adduct persistence in unstimulated human peripheral blood lymphocytes. Mut. Res., 325, 31-37.

96. Oesch, F., Aulmann, W., Platt, K.L., Doerjer, G. (1987) Individual differences in DNA repair capacities in man. Arch. Toxicol. Suppl., 10, 172-179.

97. Schulte, P.A., Perera, F.P.(1993) Molecular epidemiology. Principles and practices. San Diego, U.S.A., Academic Press

98. Strickland, P., Kang, D., Sithisarankul, P. (1996) Polycyclic aromatic hydrocarbon metabolites in urine as biomarkers of exposure and effect. Environ. Health Perspect. 104, Suppl. 5, 927-932.

99. Gupta, R.C., Earley, K., and Sharma, S. (1988) Use of human lymphocytes to measure DNA binding capacity of chemical carcinogens. Proc. Natl. Acad. Sci., 85, 3513-3517.

100. Nowak, D., Schmidt-Preuss, U., Jorres, R., Liebke, F., and Rüdiger, H.W. (1988) Formation of adducts and water-soluble metabolites of $\mathrm{B}(\mathrm{a}) \mathrm{P}$ in human monocytes is genetically controled. Int. I. Cancer 41, 169-173.

101. Hawke, L.J. and Farrell, G.C.(1986) Increased binding of benzo(a)pyrene metabolites toiymphocytes from patients with lung cancer. Cancer Lett., 30, 289-297.

102. Nowak, D., Meyer, A., Schmidt-Preuss, U., Gatzemeier, U., Magnussen, H., Rüdiger, H.W. (1992) Formation of benzo(a)pyrene-DNA adducts in blood monocytes from lung cancer patients with a familial history of lung cancer. I. Cancer Res. Clin. Oncol., 118, 67-71.

103. Schut, H.A.J., Shiverick, K.T. (1992) DNA adducts in humans as dosimeters of exposure to environmental, occupational or dietary genotoxins. FASEB J., 6, 2942-2951.

104. Van Maanen, J.M.S., L.M. Maas, Hageman G., J.C.S. Kleinjans and B. van Agen (1994) DNA adduct and mutation analysis in white blood cells of smokers and non smokers. Environ. Mol. Mutagenesis, 24, 46-50. 
105. Phillips, D.H., A. Hewer and P.L. Grover (1986) Aromatic DNA adducts in human bone marrow and peripheral blood leukocytes. Carcinogenesis, 7, 2071-2075.

106. Phillips, D.H., B. Schoket, A. Hewer, E. Bailey, S. Kostic and I. Vincze (1990) Influence of cigarette smoking on the levels of DNA adducts in human bronchial epithelium and white blood cells. Int. J. Cancer, 46, 569-575.

107. Herbert, R., Marcus, M., Wolff, M.S., Perera, F.P., Andrews, L., Godbold, J.H., Rivera, M., Stefanidis, M., Lu, X-Q., Landrigan, P.J., and Santella, R.M. (1990) Detection of adducts of deoxyribonucleic acid in white blood cells of roofers by ${ }^{32} \mathrm{p}$-postlabeling. Relationship of adduct levels to measures of polycyclic aromatic hydrocarbons. Scand. I. Work Environ. Health, 16, 135-143.

108. Rothman, N., Correa-Villasenor, A., Ford, D.P., Poirier, M.C., Haas, R.A., Hansen, J.A., OToole, T., Strickland, P.T. (1993) Contribution of occupation and diet to white blood cell PAH DNA adducts in wildland firefighters. Cancer Epidemiol. Biomarkers \& Prev. 2. 341-347.

109. Van Maanen, J.M.S., Moonen, E.J.C., Maas, L.M., Kleinjans, J.C.S., Van Schooten, F.J. (1994) Formation of aromatic DNA adducts inwhite blood cells in relation to urinary excretion of 1-hydroxy-pyrene during consumption of grilled meat. Carcinogenesis, 15 , 2263-2268.

110. Rothman, N., Poirier, M.C., Haas, R.A., Correa-Villasenor, A., Ford, P., Hansen, J.A. OToole, T., Strickland, P.T.(1993) Association of PAH DNA adducts in peripheral white blood cells with dietary exposure to PAH. Environ. Health Perspect, 99, 265-267.

111. Phillips, D.H., Schoket, B., Hewer, A., Bailey, E., Kostic, S., and Vincze, I. (1990) Influence of cigarette smoking, on the levels of DNA adducts in human bronchial epithelium and white blood cells. Int. I. Cancer, 46, 569-575.

112. Van Schooten, F.J., Hillebrand, M.J.X., Van Leeuwen, F.E., Van Zandwijk, N., Jansen, H.M., Den Engelse, L., and Kriek, E. (1992) Polycyclic aromatic hydrocarbon-DNA adducts in white blood cells from lung cancer patients: no correlation with adduct levels in lung. Carcinogenesis, 13, 987-993.

113. Wiencke, J.K., K.T. Kelsey, A. Varkonyi, K. Semey, J.C. Wain, E. Mark and D.C. Christiani (1995) Correlation of DNA adducts in blood mononuclear cells with tobacco carcinogen-induced damage in human lung. Cancer Res., 55, 49104914.

114. Okano, P., Miller, H.N., Robinson, R.C., Gelboin, H.V.(1979) Comparison of benzo[a]pyrene and (-)-trans-7,8-dihydroxy-7,8-dihydrobenzo[a]pyrene metabolism in human blood monocytes and lymphocytes. Cancer Res., 39, 3184-3193.

115. Knudsen, L.E., Ryder, L.P., Wasserman, K. (1992) induction of DNA repair synthesis in human monocytes / B-lymphocytes compared with T-lymphocytes after exposure to $\mathrm{N}$ acetoxy $\mathrm{N}$-acetylaminofluorene and dimethylsulfate in vitro. Carcinogenesis, 13, $1285-$ 1287.

116. Godschalk, R.W.L., Maas, L.M., Van zandwijk, N., Van 't veer, L., Breedijk, A., Borm, P.J.A., Verhaert, J., Kleinjans, J.C.S., Van Schooten, F.J. (1998) Differences in aromaticDNA adduct levels between alveolar macrophages and subpopulations of white blood cells from smokers. Carcinogenesis, 19, 819-825.

117. Izzotti, A., G.A. Rossi, M. Bagnasco, S. de Flora (1991) Benzo[a]pyrene diolepoxideDNA adducts in alveolar macrophages of smokers. Carcinogenesis, 12, 1281-1285.

118. De Flora, S., A. Izotti, F. D’Agostini, G.A. Rossi and R.M. Balansky (1993) Pulmonary alveolar macrophages in molecular epidemiology and chemoprevention of cancer. Environ. Health. Perspect., 99, 249-252.

119. Pavord, I.D., Pizzichini, M.M.M., Pizzichini, E., Hargreave, F.E. (1997) The use of induced sputum to investigate airway inflammation. Thorax, 52, 498-501.

120. Lutz, W.K. (1990) Dose-response relationship and low dose extrapolation in chemical carcinogenesis. Carcinogenesis, 11, 1243-1247.

121. Lewtas, J., Walsh, D., Williams, R., Dobiás, L. (1997) Air pollution exposure-DNA adduct dosimetry in humans and rodents: evidence for non-linearity at high doses. Mut. Res., 378, 51-63.

122. Van Schooten, F.J., Godschalk, R.W.L., Breedijk, A., Maas, L.M., Kriek, E., Sakai, H., Wigbout, G., Baas, P., Van 't Veer, L., Van Zandwijk, N. (1997) 32P-Postlabeling of 
aromatic DNA adducts in white blood cells and alveolar macrophages of smokers: saturation at high exposures. Mut. Res., 378, 65-75.

123. Schoket, B., Kostic, S., Vince, I. (1993) determination of smoking-related DNA adducts in lung-cancer and non-cancer patients. IARC Sci. PubL, 315-319.

124. Dunn, B.P., Vedal, S., San, R.H.C., Kwan, W.F., Nelems, B., Enarson, D.A., Stich, H. (1991) DNA adducts in bronchial biopsies. Int. I. Cancer, 48, 485-492.

125. Garner, R.C., Cuzick, J., Jenkins, D., Phillips, D.H., Hewer, A., King, M.M., Routledge, M.N. (1990) Linear relationship between DNA adducts in human lung and cigarette smoking. IARC Sci. Publ, 421-426.

126. Van Schooten FJ, Hillebrand MJX, Scherer E, Den Engelse L, Kriek E. (1991) Immunocytochemical visualization of DNA adducts in mouse tissues and human white blood cells following treatment with $\mathrm{B}(\mathrm{a}) \mathrm{P}$ or its diol epoxide. A quantitative approach. Carcinogenesis, 12, 427-433.

127. Mooney, L.V.A., Santella, R.M., Covey, L., Jeffrey, A.M., Bigbee, W., Randall, M.C., Cooper, T.B., Ottman, R., Tsai, W.Y., Wazneh, L., Glassman, A.H., Young, T.L., Perera, F.P. (1995)Decline of DNA damage and other biomarkers in peripheral blood following smoking cessation. Cancer Epidemiol. Biomarkers \& Prev., 4, 627-634.

128. Dickey, C., Santella, R.M., Hattis, D., Tang, D., Hsu, Y., Cooper, T., Young, T.L., Perera, F.P. (1997) Variability in PAH-DNA adduct measurements in peripheral mononuclear celis: implications for quantitative cancer risk assessment. Risk Analysis, 17, 649-656.

129. Jongeneelen, F.J., Anzion, R.B.M., Scheepers, P.T.J., Bos, R.P., Henderson, P.T., Nijenhuis, E.H., Veenstra, S.J., Brouns, R.M.E., Winkes, A. (1988) 1-Hydroxypyrene in urine as a biological indicator of exposure to polycyclic aromatic hydrocarbons in several work environments. Ann. Occup. Hygiene, 32, 35-43.

130. Kang, D.H., Rothman, N., Poirier, M.C., Greenberg, A., Hsu, C.H., Schwartz, B.S., Baser, M.E., Weston, A., Groopman, J.D., Strickland, P.T. (1995) Interindividual differences in the concentration of 1-hydroxypyrene-glucuronide in urine and polycyclic aromatic hydrocarbon-DNA adducts in peripheral white blood cells after charbroiled beef consumption. Carcinogenesis, 16, 1079-1085.

131. Santella, R.M., Hemminki, K., Tang, D.L., Paik, M., Ottman, R., Young, T.L., Savela, K., Vodickova, L., Dickey, C., Whyatt, R., Perera, F.P. (1993) Polycyclic aromatic hydrocarbon- DNA adducts in white blood cells and urinary 1-hydroxypyrene in foundry workers. Cancer Epidemiol. Biomarkers \& Prev., 2, 59-62.

132. Van Schooten, F.J., Jongeneelen, F.J., Hillebrand, M.J.X., Van leeuwen, F.E., de Looff, A.J.A., Dijkmans, A.P.G., van Rooij, J.G.M., den Engelse, L., Kriek, E. (1995) Polycyclic aromatic hydrocarbon-DNA adducts in white blood cell DNA and 1-hydroxypyrenein the urine from aluminum workers: relation with job category and synergistic effects of smoking. Cancer Epidemiol. Biomarkers \& Prev., 4, 69-77. 


\title{
Chapter 2
}

\section{Differences in aromatic-DNA adduct levels between alveolar macrophages and subpopulations of white blood cells from smokers}

\author{
R.W.L. Godschalk', L.M. Maas¹, N. Van Zandwijk², L. van 't Veer ${ }^{3}$, A. Breedijk², \\ P.J.A. Borm¹, J.Verhaert', J.C.S. Kleinjans' ${ }^{1}$, F.J.van Schooten' \\ ${ }^{1}$ Department of Health Risk Analysis and Toxicology, \\ University of Maastricht, Maastricht, The Netherlands \\ 2 Department of Chest Oncology and ${ }^{3}$ Department of Pathology, \\ The Netherlands Cancer Institute,Amsterdam, The Netherlands \\ ${ }^{4}$ Department of Pulmonology, \\ St. Barbara Hospital, Lanaken, Belgium
}

Carcinogenesis, vol. 19 no. 5 pp 819-825, 1998

\begin{abstract}
The ${ }^{32} \mathrm{P}$-postlabeling assay for DNA adduct quantification gives the opportunity to examine endogenous exposure to DNA reactive compounds. Most human biomonitoring, studies applied white blood cells (WBC) or cells obtained by broncho-alveolar lavages. (BAL) as source of DNA, but still it is not clear what cell type represents the most reliable indicator for exposure to cigarette smoke associated gerotoxins. At first, we examined DNA adduct levels by means of nuclease P1 (NP1) enriched ${ }^{32} \mathrm{P}$-postlabeling in separated WBC subpopulations after in vitro incubations for eighteen hours with $10 \mu \mathrm{M}$ benzo[a]pyrene (B[a]P). DNA adduct levels were highest in monocytes $\left(10.7 \pm 2.9\right.$ adducts $/ 10^{8}$ nucleotides, $\left.n=8\right)$, followed by lymphocytes $(5.9 \pm 1.7, \mathrm{n}=8)$, and granulocytes $(0.5 \pm 0.2, \mathrm{n}=8)$. Secondly, aromatic-DNA adduct levels were determined in BAL cells and WBC-subsets from (non)smoking volunteers. In smoking individuals, adduct levels were in the ranking order: BAL cells $(3.7 \pm 1.0, n=5)>$ monocytes $(2.0 \pm 0.5, n=8) \geq$ lymphocytes $(1.6 \pm 0.4$, $\mathrm{n}=8)>$ granulocytes $(0.8 \pm 0.2, \mathrm{n}=8)$ by NP1-enrichment and monocytes $(9.0 \pm 3.2$, $\mathrm{n}=5) \geq$ lymphocytes $(8.0 \pm 2.1, \mathrm{n}=6)>$ granulocytes $(2.1 \pm 0.3, \mathrm{n}=7)$ by butanol enriched ${ }^{32} \mathrm{P}$-postlabeling. Arromatic-DNA adduct levels were significantly higher in WBCsubsets of smokers as compared to nonsmokers, except for DNA adducts in granulocytes using butanol enrichment. Thirdly, dose-response relationships were investigated in mononuclear white blood cells (MNC i.e. monocytes plus lymphocytes) and BAL-cells of a larger group of smoking individuals $(n=78)$. Adduct levels in MNC were related to daily exposure to cigarette-tar ( $r=0.31$, $\mathrm{p}<0.01 \%$. Adduct levels in BAL cells seemed to be correlated with pack-years, but after correction. for age this relationship was lost. Butanol extraction resulted in 5-6 fold higher DNA adduct levels in MNC, whereas butanol extraction of BAL-DNA of the same individuals yielded only 2 -fold higher adduct levels. The two enrichment procedures of ${ }^{32} \mathrm{P}$-postlabeling were correlated in BAL cells $(r=0.86, p<0.001, \mathrm{n}=12)$. We conclude that particulariy' MNC are good surrogates for the detection of smoking-related DNA adducts.
\end{abstract}




\section{Introduction}

The general population is exposed to polycyclic aromatic hydrocarbons (PAH) via drinking, water, food and polluted air (cigarette smoke). In tobacco smoke over 40 compounds including PAH, tobacco specific nitrosamines and aromatic amines were found to elicit cancer in experimental animals. Recently Denissenko et al. (1) confirmed that the environmental pollutant benzo[a]pyrene (B[a]P) plays an important role in the etiology of lung cancer. PAHs exert their carcinogenic effects via covalent interactions of reactive metabolites with DNA. The resulting DNA adducts have been studied as a measure of the biologically effective dose and as an indicator for cancer risk in PAH treated animals (2-4). ${ }^{32} \mathrm{P}$-postlabeling is frequently used to study carcinogen-DNA adducts in humans. It is sensitive and can be successfully applied to monitor exposure to complex mixtures. To enhance the sensitivity of this assay, adduct enrichment procedures are performed by either butanol extraction of adducted nucleotides, or by selective dephosphorylation of unadducted nucleotides by nuclease P1 (NP1). Overall, the butanol enhancement method seems to be more sensitive, but for assessing exposures to unknown chemical mixtures both enhancement methods are recommended (5). Samples of target tissues are difficult to collect and white blood cells (WBC) are often used as a surrogate. The validity of measurements in surrogate sources of DNA however is a matter of discussion. In the human lung, hydrophobic aromatic DNA adduct levels appeared to be linearly related to the amount of cigarettes smoked per day (6). Conflicting results have been reported on the occurrence of PAH-DNA adducts in peripheral blood cells of smokers (7-10). No clear differences between PAH-DNA adduct levels in WBC of smokers and non-smokers have been found and moreover large interindividual variations were observed. WBC can be divided in three subpopulations: short living granulocytes (40-75\%) and monocytes (5-10\%), and long living lymphocytes $(20-40 \%)$. They also differ in metabolizing (11) and repair capacity (12). Consequently, their contribution to DNA adduct concentrations in total WBC-DNA will be variable. Another surrogate source of exposed DNA is derived from cells obtained by bronchoalveolar lavages (BAL) as suggested by Izotti et al. (13) and De Flora et al. (14). Alveolar macrophages (AM), the predominant cell-

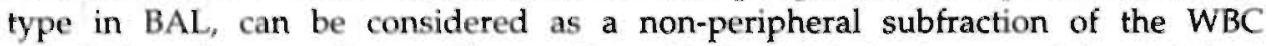
population, because these cells are thought to originate from peripheral blood monocytes that have left the circulation. Although these various cell types have been applied in several human studies to assess the biologically effective dose, they were never compared in the same study. It was the aim of this study to examine the differences in aromatic DNA adduct levels of alveolar macrophages and subpopulations of white blood cells from smokers. In view of the heterogeneity of the total WBC population, we examined the in vitro formation of DNA adducts in three subpopulations of human peripheral white blood cells: monocytes, lymphocytes and granulocytes after treatment with B[a]P for 18 hours. Furthermore, we investigated the presence of DNA adducts in separated WBC-subsets and BALcells of eight smoking patients suffering from pneumoconiosis or COPD. Adduct levels were determined by means of NP1 or butanol enriched ${ }^{32}$ P-postlabeling with 
thin layer chromatography (TLC). Subsequently, aromatic-DNA adduct levels were investigated in mononuclear white blood cells (MNC, i.e. monocytes plus lymphocytes) and BAL cells of a second, larger study population of healthy smokers $(n=78)$ to establish dose-response relationships. Furthermore, WBC subsets of nonsmoking volunteers were sampled to assess background levels of aromatic DNA adducts.

\section{Materials \& Methods}

\section{Chemicals}

All solutions used were sterile. B[a]P was purchased from Sigma (St. Louis, MO, USA). RPMI 1640, streptomycin/penicillin, L-glutamin and fetal calf serum (FCS) were all obtained from Gibco (Europe). Lymphoprep ${ }^{\mathrm{TM}}(1.077 \mathrm{~g} / \mathrm{ml}$ ) was obtained from Nycomed (Oslo, Norway). All other chemicals were purchased from Merck (Darmstadt, Germany). Water was purified by means of a milli-Q purification system.

\section{Study populations}

The overall characteristics of the study populations are summarized in Table I. Study population 'Maastricht' (MAAS-I) involves blood from eight healthy male, non-smoking volunteers (age: $27 \pm 2 \mathrm{yr}$., range 23-36) and WBC-subpopulations of these individuals were in vitro exposed to $\mathrm{B}[\mathrm{a}] \mathrm{P}$ as described below. The second 'Maastricht' study population (MAAS-II) involves 5 male and 10 female putatively unexposed, nonsmoking volunteers (age: $33 \pm 3$, range 18-52). WBC-subpopulations of these individuals were used as control. In study population 'Lanaken' (LAN) blood and BAL was obtained from 8 smoking male patients (age: $63 \pm 7$, range 31-81) from the St. Barbara Hospital (Lanaken, Belgium). BAL was performed in these individuals as a part of the diagnostic process in patients with putative pneumoconiosis, COPD or lung cancer. Patients with an active inflammatory process were excluded. Sampling of blood and BAL was performed from April to July 1995. Study population 'Amsterdam' (AMS) consisted of 26 male and 52 female healthy smoking volunteers (age: $43 \pm 9$, range 25-64). Blood and BAL were sampled over the period October 1994 to September in 1995. These studies were approved by the medical ethical committees of the Netherlands Cancer Institute (AMS) and the Maastricht University (Maas I and II, LAN) and informed consent was obtained in all cases.

Isolation of subpopulations of human white blood cells for in vitre incubations Fifty $\mathrm{ml}$ of peripheral blood of eight healthy nonsmoking volunteers was sampled by venapuncture into EDTA-tubes. Polymorphonuclear cells (granulocytes) were separated from MNC by gradient centrifugation on lymphoprep according to Boyum (15). Both fractions were washed with PBS. The granulocyte fraction was treated with lysis buffer ( $155 \mathrm{mM} \mathrm{NH}_{4} \mathrm{Cl}, 10 \mathrm{mM} \mathrm{KHCO}_{3}, 10 \mathrm{mM}$ EDTA, pH 7.4) to lyse the erythrocytes and washed with PBS. In a next series of in vitro experiments, total white blood cells were collected after precipitation of erythrocytes in gelatin 
$(1 \% \mathrm{w} / \mathrm{v})$. The WBC were washed with PBS, $0.1 \%$ BSA and separated into mononuclear cells and polymorphonuclear cells as described above.

Table I: Overall characteristics of the study-populations of Maastricht (MAAS-I and MAAS-II) and Amsterdam (AMS) in the Netherlands and Lanaken (LAN) in Belgium.

\begin{tabular}{|c|c|c|c|c|}
\hline & $\begin{array}{l}\text { MAAS-I } \\
\text { 'Healthy' } \\
\text { Nonsmokers }\end{array}$ & $\begin{array}{l}\text { MAAS-II } \\
\text { 'Healthy' } \\
\text { Nonsmokers }\end{array}$ & $\begin{array}{l}\text { AMS } \\
\text { 'Healthy' } \\
\text { Smokers }\end{array}$ & $\begin{array}{l}\text { LAN } \\
\text { Smoking COPD } \\
\text { Patients }\end{array}$ \\
\hline$n$ & 8 & 15 & 78 & 8 \\
\hline Male/Female & $8 / 0$ & $5 / 10$ & $26 / 52$ & $8 / 0$ \\
\hline Age (mean $t$ se) $27 \pm 2$ & $33 \pm 3$ & $43 \pm 9$ & $63 \pm 7$ & \\
\hline (Range) & $23-36$ & $18-52$ & $25-64$ & $31-81$ \\
\hline Sampling Period & 1994 & $\begin{array}{l}\text { July-Dec. } \\
1996\end{array}$ & $\begin{array}{l}\text { Oct.1994- } \\
\text { Sept. } 1995\end{array}$ & $\begin{array}{l}\text { Apr.-June } \\
1995\end{array}$ \\
\hline Samples & WBC-Subsets & $\begin{array}{l}\text { WBC-Subsets } \\
\text { MNC }\end{array}$ & $\begin{array}{l}\text { MNC } \\
\text { BAL }\end{array}$ & $\begin{array}{l}\text { WBC-Subsets } \\
\text { BAL }\end{array}$ \\
\hline \multicolumn{5}{|c|}{ BAL differentiation count (\%) } \\
\hline Alveolar Macrophages & NP. & NP. & $78 \pm 10$ & $80 \pm 10$ \\
\hline Polymorphonuclear Cells & & & $0 \pm 0$ & $12 \pm 7$ \\
\hline Lymphocytes & & & $<1$ & $5 \pm 2$ \\
\hline Epithelial Cells & & & $22 \pm 10$ & $4 \pm 3$ \\
\hline
\end{tabular}

NP., not performed

In vitro treatment of white blood cells with benzolalpyrene

Cells were suspended at a concentration of $2 \times 10^{6}$ cells $/ \mathrm{ml}$ in RPMI 1640, supplemented with $10 \%$ FCS, $2 \mathrm{mM} \mathrm{L}$-glutamin, $10 \mathrm{IU} / \mathrm{ml}$ penicillin and $10 \mu \mathrm{g} / \mathrm{ml}$ streptomycin. B[a]P was dissolved in dimethylsulfoxide (DMSO) and added to the cells to yield a final concentration of $10 \mu \mathrm{M}$. In all incubations the DMSO concentration did not exceed $0.5 \%$. Cells were incubated for 18 hours $\left(37^{\circ} \mathrm{C}, 5 \% \mathrm{CO}_{2}\right.$ : $95 \% \mathrm{O}_{2}$ ). Viability was checked by means of trypan-blue exclusion. After the incubations, granulocytes and lymphocytes, were collected, centrifuged and washed twice with PBS. The remaining monocytes, which adhere to plastic surfaces, were washed twice with PBS buffer and immediately lysed within the T.C.-flask for DNA isolation.

\section{Isolation of WBC subfractions of patients and healthy volunteers}

Mononuclear white blood cells and granulocytes were isolated from $10 \mathrm{ml}$ peripheral blood as described above. Monocytes and lymphocytes were resuspended in RPMI 1640 (supplemented with $10 \%$ FCS, 2. mM L-glutamin, 10 $\mathrm{IU} / \mathrm{ml}$ penicillin and $10 \mu \mathrm{g} / \mathrm{ml}$ streptomycin) at a concentration of ca. $1 \times 10^{6}$ cells per $\mathrm{ml}$ and separated by adherence of monocytes to plastic T.C.-flasks for 40 minutes at $37^{\circ} \mathrm{C}$. Cells were stored at $-20^{\circ} \mathrm{C}$ until DNA-isolation.

Performance of the bronchoalveolar lavages 
Bronchoscopy in the AMS study population was performed under local anesthesia (lidocaine). The bronchoscope was placed into the right middle lobe bronchus and $180 \mathrm{ml}$ of sterile saline $\left(37^{\circ} \mathrm{C}\right)$ was instilled in nine aliquots of $20 \mathrm{ml}$ each. The dwell time was about 3 minutes. Bronchoalveolar lavages of the LAN study population was performed by introducing $50 \mathrm{ml}$ of $0.9 \%$ normal saline into the lung. Then, immediately suction ( $60 \mathrm{~mm} \mathrm{Hg}$ ) was applied. This procedure was performed four times. BAL fluids were directly collected in plastic tubes and placed on ice. Cells were counted and after centrifugation $\left(4^{\circ} \mathrm{C}, 1500 \mathrm{~g}, 10\right.$ minutes), the cell pellet was stored at $-70^{\circ} \mathrm{C}$ until DNA isolation.

\section{DNA isolation}

WBC-subpopulations were lysed with $2.5 \mathrm{ml}$ SDS/NEP (75 mM NaCl, $25 \mathrm{mM}$ EDTA, $50 \mu \mathrm{g} / \mathrm{ml}$ Proteinase K, $1 \%$ SDS) and incubated for 4 hours at $37^{\circ} \mathrm{C}$. DNA was extracted with phenol: chloroform: isoamylalcohol $(25: 24: 1, v / v / v)$, and chloroform: isoamylalcohol $(24: 1, \mathrm{v} / \mathrm{v})$ respectively. The DNA was precipitated with two volumes of cold ethanol after addition of $1 / 30$ volume $3 \mathrm{M}$ sodiumacetate, $\mathrm{pH}$ 5.3 and washed with $70 \%$ ethanol . Subsequently, DNA was dissolved in $2 \mathrm{mM}$ Tris, $\mathrm{pH}$ 7,4. Concentration and purity were determined spectrophotometrically by absorbance at 230, 260 and $280 \mathrm{~nm}$. The mean spectrophotometrical ratios of $\mathrm{A}_{260} / \mathrm{A}_{280}$ and $\mathrm{A}_{230} / \mathrm{A}_{260}$ were respectively 1.67 (range: $1.55-1.83$ ) and 0.45 (0.420.50 ). The final volume was adjusted to achieve a DNA-concentration of $2 \mathrm{mg} / \mathrm{ml}$.

\section{2 -postlabeling}

The 32P-postlabeling assay was performed as described by Reddy and Randerath (16) with some modifications. All samples were analyzed blindly. DNA (10 $\mu \mathrm{g})$ was digested using micrococcal endonuclease (0.4 Units) and spleen phosphodiesterase $(2.8 \mu \mathrm{g})$ for 3 hours at $37^{\circ} \mathrm{C}$. Subsequently, half of the digest was treated with nuclease P1 $(6.3 \mu \mathrm{g})$ for 40 minutes at $37^{\circ} \mathrm{C}$. Butanol enrichment was performed according to Gallagher et al. (17). The modified nucleotides were labeled with [ $y-32 \mathrm{P}]-$ ATP $(50 \mu \mathrm{Ci} /$ sample) by incubation with T4-polynucleotide kinase (5.0 Units) for 30 minutes at $37^{\circ} \mathrm{C}$. $\left[\gamma^{32} \mathrm{P}\right]-\mathrm{ATP}$ was synthesized in the laboratory using carrier free ${ }^{32} \mathrm{P}$ (Dupont, Brussels, specific activity: $8500-9120 \mathrm{Ci} / \mathrm{mmol}$ ). NP1-efficiency and ATPexcess were checked with an aliquot of the NP1 treated fraction by one-dimensional chromatography on poly(ethylene imine)(PEI)-cellulose sheets from Merck, Germany (solvent: $0.12 \mathrm{M} \mathrm{NaH} \mathrm{PO}_{4} \mathrm{pH}$ 6.8). Radiolabeled adduct nucleotide biphosphates were separated by chromatography on PEI-cellulose sheets from Machery Nagel (Germany). The following solvent systems were used: D1, $1 \mathrm{M}$ $\mathrm{NaH}_{2} \mathrm{PO}_{4} \mathrm{pH} 6.5 ; \mathrm{D} 2,8.5 \mathrm{M}$ urea, 5.3 $\mathrm{M}$ lithium formate $\mathrm{pH} 3.5 ; \mathrm{D} 3,1.2 \mathrm{M}$ lithium chloride, 0.5 M Tris, 8.5 M urea pH 8.0; D4, $1.7 \mathrm{M} \mathrm{NaH}_{2} \mathrm{PO}_{4} \mathrm{pH}$ 6.0. In each experiment, 3 standards of [ $\left.{ }^{3} \mathrm{H}\right] \mathrm{BPDE}$ modified DNA with known modification levels ( 1 per $10^{7}, 10^{8}, 10^{9}$ nucleotides) were run parallelly for quantification purposes. Quantification was performed by using phosphor-imaging technology (Molecular

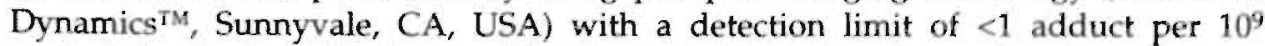
nucleotides for individual spots. The detection limit of a diagonal radioactive zone. (DRZ) was around 5 adducts per $10^{9}$ nucleotides. The remaining half of the digest 
was used to determine the final amount of DNA in the assay; the normal nucleotides were diluted and labeled with $\left[\gamma^{32} \mathrm{P}\right]-\mathrm{ATP}(15 \mu \mathrm{Ci} / \mathrm{sample})$ by incubation with T4polynucleotide kinase ( 2.5 Units) and a 10-fold molar excess of unlabeled ATP for 30 minutes at $37^{\circ} \mathrm{C}$. A dAp standard $(27.5 \mathrm{pmole} / \mu \mathrm{l})$ was labeled in each experiment for quantification purposes. Nucleotides were separated by one-dimensional chromatography on PEI-cellulose sheets from Merck (solvent: $0.12 \mathrm{M} \mathrm{NaH}_{2} \mathrm{PO}_{4} \mathrm{pH}$ 6.8); samples with apparent protein or RNA contamination were discarded.

\section{Statistics}

Results are presented as mean \pm standard error of the mean. Nonparametric-tests were applied for differences between blood cell subsets (Wilcoxon, paired samples), and for comparison of smokers versus nonsmokers (Mann-Whitney, unpaired samples). Linear regression was used to assess the relations between cell-types, enrichment procedures and to assess dose-responses. $\mathrm{P}<0.05$ was considered significant.

\section{Results}

\section{In vitro treatment of white blood cells with Bla]P}

After 18 hours of in vitro incubation with $\mathrm{B}[\mathrm{a}] \mathrm{P}$, the predominant adduct detected in DNA of human WBC-subpopulations comigrated with the major adduct of the [ $\left.{ }^{3} \mathrm{H}\right] \mathrm{BPDE}-\mathrm{DNA}$ standard, putatively BPDE covalently linked with deoxyguanosine (BPDE-dG), The BPDE-DNA adduct standard is shown in the adduct profiles of Figure 1 (Panel E). Highest DNA adduct levels were found in monocytes, 10.7 \pm 2.9 BPDE-DNA $/ 10^{8}$ nucleotides (range 3.0-25.3), followed by lymphocytes, 5.9 1.7 BPDE-DNA $/ 10^{8}$ nucleotides (range 0.6-12.8), whereas granulocyte DNA contained substantially lower levels, $0.5 \pm 0.2$ BPDE-DNA $/ 10^{8}$ nucleotides (range 0.04-1.7), using the NP1 method for DNA adduct enrichment (Figure 2). Adduct levels in monocytes and lymphocytes differed significantly from adduct levels in granulocytes (respectively $p=0.012$ and $p=0.008$ ). Most individuals $(7 / 8)$ showed higher adduct levels upon in vitro incubation in monocytes as compared with lymphocytes, although the means did not differ significantly. Large interindividual variations were observed; 8,20 and 42 fold differences in respectively monocytes, lymphocytes and granulocytes (percentage of variance were respectively $76 \%, 83 \%$ and $135 \%$ ). To assess the total experimental variation of the in vitro experiment, lymphocytes obtained from 5 healthy male volunteers, were exposed to B[a]P in triplicate and analyzed for DNA adducts using the NP1 enriched 32P-postlabeling assay; the mean coefficient of variation was $18.2 \pm 2.9 \%$ (range: $2 \%-40 \%, n=5$ ) for parallel experiments.

After separation of the polymorphonuclear cells and mononuclear cells, the granulocytes were treated with lysis buffer to remove the erythrocytes. To exclude an effect of lysisbuffer on the PAH-DNA adduct forming capacity of granulocytes, in a separate set of experiments $(n=3)$ the erythrocytes were removed from the diluted whole blood by gelatin precipitation. Using this less drastic method for erythrocyte removal, the results were similar (data not shown). 


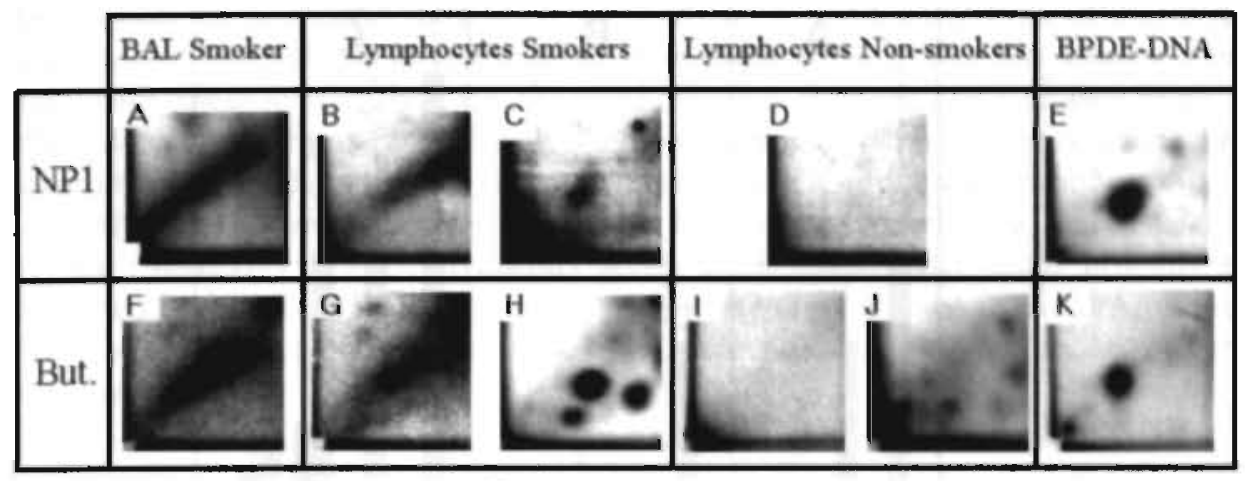

Figure 1. Adduct profiles obtained by ${ }^{32} \mathrm{P}$-postlabeling. Origins are located at the lower left corner and were excised before analysis. Differences in chromatography and intensity are due to interassay variations. (A,B,F,G) Typical diagonal radioactive zones as observed in lymphocytes or BAL cells of smokers. (C, H) DNA adduct spots detected in lymphocytes of smokers. The DNA adduct spot in panel C comigrated with the BPDE-DNA adduct standard. (D, I, J) Lymphocytic DNA of nonsmokers (E,K) BPDE-DNA adduct standard (1 adduct per $10^{7}$ nucleotides).

\section{Adducts in WBC and BAL in vivo in (non)smoking humans}

In smoking individuals (LAN-study population, Table I) diagonal radioactive zones (DRZ) were found, which are typical for exposure to cigarette smoke (Figure 1, Panel A and B). In monocytes and lymphocytes, but not in granulocytes of some individuals $(5 / 8)$ also distinct adduct spots were observed, of which some comigrated (3/8) with the BPDE-DNA adduct standard (Figure 1, Panel C). Total adduct levels were highest in respectively BAL-cells $(3.7 \pm 1.0, \mathrm{n}=5)$, peripheral blood monocytes $(2.0 \pm 0.5, n=8)$, lymphocytes $(1.6 \pm 0.4, n=8)$ and granulocytes $(0.8 \pm 0.2$, $\mathrm{n}=8, \mathrm{p}<0.05$ ) using NP1 enriched ${ }^{32} \mathrm{P}$-postlabeling (Figure 2). Similarly, butanol extraction resulted in DRZ's and distinct adduct spots. (Figure 1, panel F, G and $H$ ), although individual adduct profiles were not always identical when compared with the NP1-method. For example, adduct spots in lymphocytic DNA as shown in Figure 1 panel $\mathrm{H}$, were found in this subject after application of butanol extraction, whereas after NP1 enrichment a DRZ was observed. To ensure that the observed adduct spots were no background spots, as occasionally seen with the butanol procedure, samples were analyzed in two or three independent experiments. Furthermore, these spots were absent in control samples of the same experiment. Total adduct levels in WBC subsets were ca. 6 fold higher by the butanol procedure as compared with NP1 enrichment: monocytes $(9.0 \pm 3.2 ; n=5)$, lymphocytes $(8.0 \pm 2.1$; $\mathrm{n}=6$ ) and granulocytes $(3.0 \pm 0.9 ; \mathrm{n}=7$ ) (Figure 2) (the amount of BAL-DNA was too small for analysis by NP1 and butanol enrichment). 


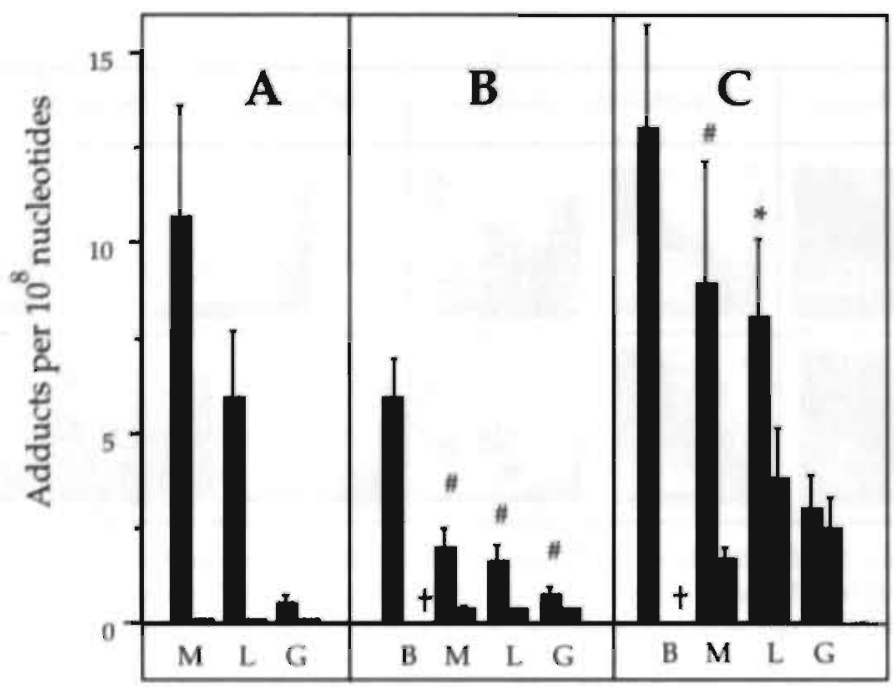

Figure 2. DNA adduct levels in BAL cells (B), monocytes (M), lymphocytes (L) and granulocytes (G). (A) After in vitro treatment with $10 \mu \mathrm{M}$ B $[\mathrm{a}] \mathrm{P}$ for $18 \mathrm{~h}$. (B) Determined by NP1 enriched ${ }^{32 \mathrm{P}}$ postlabeling in smokers ( $\mathbf{n}$ ) and nonsmokers ( $\mathbf{a}$ ). (C) Determined by butanol enriched $32 \mathrm{P}$ postlabeling. " $\mathrm{P}<0.05$ and $\mathrm{P}<0.10$, as compared to nonsmokers.t No BAL was performed in nonsmokers.

In DNA of WBC subsets of most nonsmoking controls (12/15) neither DRZ's nof adduct spots were found by NPI enrichment. For statistical reasons, adduct levels of these samples were arbitrarily set at one half of the detection limit for DRZ's ( 0.25 adducts per $\left.10^{8} \mathrm{nt}\right)$. In three nonsmokers, a faint DRZ was observed and adduct levels were marginally increased above the detection limit. Mean aromatic DNA adduct levels in monocytes, lymphocytes and granulocytes were respectively $0.35 \pm 0.07,0.34 \pm 0.05$ and $0.33 \pm 0.04$, which were significantly lower as compared with smoking individuals (monocytes: $p<0.01$, lymphocytes: $p<0.001$, granulocytes: $\mathrm{p}=0.034$ ) (Figure 2). When butanol enrichment was applied, adduct spots could be detected in $8 / 15$ nonsmokers (Figure 1), but quantitative and qualitative differences between nonsmokers and smokers were present. In nonsmokers, mean adduct levels were $1.7 \pm 0.3$ in monocytes $(n=4, p=0.021$ as compared to smokers), $3.8 \pm 1.3$ in lymphocytes $(n=9, p=0.09)$ and $2.5 \pm 0.8$ in granulocytes $(n=9, p=0.56)$ (Figure 2$)$.

\section{Dose-response relationships in MNC and BAL from smoking individuals}

In the larger group of healthy smoking volunteers (Table I, AMS-study population) dose-response relationships between smoking and adduct levels in MNC and BAL were investigated. Overall, adduct levels in MNC and BAL were respectively $1.8 \pm 0.1(n=78)$ adducts per $10^{8}$ nucleotides and $6.3 \pm 0.4(n=53)$ by NP1 enrichment. The butanol procedure resulted in respectively $8.2 \pm 0.8(n=14)$ and $13.9 \pm 1.2(\mathrm{n}=20)$. The amounts of cigarettes consumed per day (cig/day), exposure to cigarette-tar per day ( $\mathrm{mg}$ tar/day; calculated on basis of cig/day and the tar content 
of the cigarettes) and pack-years (Daily cigarette consumption/20 multiplied with the number of years the individual smoked) were used as indices of exposure. Nonsmoking individuals were excluded from the analysis (Table II). A modest but significant linear relationship was observed between aromatic-DNA adduct levels in MNC determined by NP1 mediated 32P-postlabeling and tar exposure (excluding nonsmokers: $r=0.31, p=0.005$, Figure 3 ), but not cigarette consumption ( $r=0.18$, $\mathrm{p}=0.100)$ or pack-years $(\mathrm{r}=0.14, \mathrm{p}=0.239)$. In some of the heavy smokers $(>30$ cig/day) relatively low DNA adduct levels were found, that could possibly be explained by the low tar content of the cigarette brand they consumed. AromaticDNA adduct concentrations in BAL-cells were not found to be related to the exposure level.

Table II: Linear regression analysis between DNA adducts in MNC or BAL-cells and exposure indices in AMS study population 1. Cigarettes per Day 2. Cigarette-tar per day and 3. Pack-years. Nonsmokers were excluded from the analysis.

\begin{tabular}{|c|c|c|c|c|c|c|c|}
\hline & \multicolumn{2}{|c|}{ Cigarettes / Day } & \multicolumn{2}{|c|}{ Cigarette-tar/Day } & \multicolumn{2}{|c|}{ Pack-Years } & \multirow[t]{2}{*}{$\mathbf{n}$} \\
\hline & $\mathrm{r}$ & $\mathrm{p}$ & $r$ & $\mathrm{p}$ & $r$ & $\mathrm{p}$ & \\
\hline $\begin{array}{l}\text { MNC } \\
\text { (NP1) }\end{array}$ & 0.18 & 0.100 & 0.31 & $0.005^{*}$ & 0.14 & 0.239 & 78 \\
\hline $\begin{array}{l}\text { MNC } \\
\text { (Butanol) }\end{array}$ & 0.04 & 0.902 & 0.06 & 0,842 & 0.29 & 0.322 & 14 \\
\hline $\begin{array}{l}\text { BAL } \\
\text { (NP1) }\end{array}$ & 0.20 & 0.150 & 0.01 & 0.989 & 0.12 & 0.383 & 53 \\
\hline $\begin{array}{l}\text { BAL } \\
\text { (Butanol) }\end{array}$ & 0.36 & 0.122 & 0.33 & 0.160 & 0.56 & $0.01^{*}$ & 20 \\
\hline
\end{tabular}

After application of butanol extraction, a significant relationship was observed between DNA adduct levels in BAL cells and pack-years $(r=0.561, p=0.01)$. However, pack-years were also correlated with age and additional statistical analysis by multiple regression showed that the levels of aromatic-DNA adducts in BAL-cells were age-dependent. Consequently, after correction for age the relationship between pack-years and DNA adducts in BAL disappeared. DNA adduct levels in BAL cells and MNC were not significantly interrelated $(r=0.19, p=0.33)$. Although DNA adduct levels in BAL cells after butanol enrichment were about 2-fold higher as compared with NP1 enriched adduct levels, both enrichment procedures were highly correlated ( $r=0.86, \mathrm{p}<0.001, \mathrm{n}=12$ ). On the contrary, in MNC of smoking individuals no such relationship could be observed $(r=0.01, p=0.97, n=12)$. When sufficient amount of DNA was available then DNA samples were analyzed in two or three independent experiments to assess interassay variation \pm SE which was for lymphocytic DNA $19.1 \pm 2.4 \%(53 / 78)$ and for BAL-DNA $10.9 \pm 2.5 \%(18 / 53)$. 


\section{Discussion}

In this study, we examined DNA adduct levels in separated WBC (lymphocytes, monocytes or granulocytes) after exposure to B[a]P in vitro or cigarette smoke in vivo. DNA adduct levels were higher in human monocytes and lymphocytes compared with granulocytes after in vitro incubation with $\mathrm{B}[\mathrm{a}] \mathrm{P}$ and in smoking individuals the ranking order was BAL-cells $>$ monocytes $\geq$ lymphocytes $>$ granulocytes. DNA adduct levels in the WBC were significantly higher in smokers as compared with nonsmokers by NP1 as well as butanol enriched ${ }^{32} \mathrm{P}$-postlabeling, except for aromatic-DNA adducts in granulocytes assessed by butanol enrichment.

A substantial amount of data on the presence of PAH-DNA adducts in WBC has been collected during the last decade $(7,9,18-21)$. The relationship between the level of external exposure and the biologically effective dose is uncertain, presumably because DNA adducts were measured in total WBC (18-21). Depending on a person's health, WBC subpopulations differ in life-time and relative quantities. Consequently, the contribution of WBC subpopulations to the amount of DNA adducts in total WBC is different and variable. Monocytes and granulocytes are short living and DNA adducts in these cells are therefore expected to give information about recent $\mathrm{PAH}$ exposure. On the other hand, lymphocytes may live for years and may reflect exposures that occurred both recently and in the past. Several human studies found that smoking related DNA adduct levels, PAH-DNA adducts as well as 7-methylguanine levels, were lower in granulocytes when compared to lymphocytes $(7,22)$. Some of the studies that compared WBC DNA from smokers and non-smokers by ${ }^{32} \mathrm{P}$-postlabeling have shown conflicting results on the formation of DNA adducts (7, 9-10, 23-24). Other studies suggest that adducts in WBC DNA may result from PAH sources other than tobacco smoking, for instance oral or dermal exposure $(25-30)$. Rothman et al. $(26,27)$ and van Maanen et al. (31) found a rapid appearance and removal of adducts in human WBC after consumption of charcoal broiled beef. This indicates that short living monocytes or granulocytes rather than long living lymphocytes are involved in DNA adduct formation in WBC. In this respect, more detailed and controlled studies are required on PAH-DNA adduct formation in the various WBC subpopulations.

After in vitro incubation of separated WBC-fractions with B[a]P, we found that the level of B[a]P-DNA adducts in monocytes is 22-fold higher compared to granulocytes and about 2-fold higher than in lymphocytes. Furthermore, large interindividual variation in in vitro adduct formation has been found; variation was lower in monocytes and lymphocytes compared with granulocytes, indicating that separation of cell types might decrease interindividual variability. Similarly, Gupta et al. (32) observed 18-fold interindividual variations in isolated lymphocytes after exposure to $30 \mu \mathrm{M} B[a] P$. This variation could be due to differences in metabolic activation and/or DNA-repair $(33,34)$. It is shown that interindividual differences in in vitro formation of B[a]P-DNA adducts are genetically controlled (35) and that an increased carcinogen-DNA adduct formation may indicate a constitutionally enhanced lung cancer risk (36-38). 


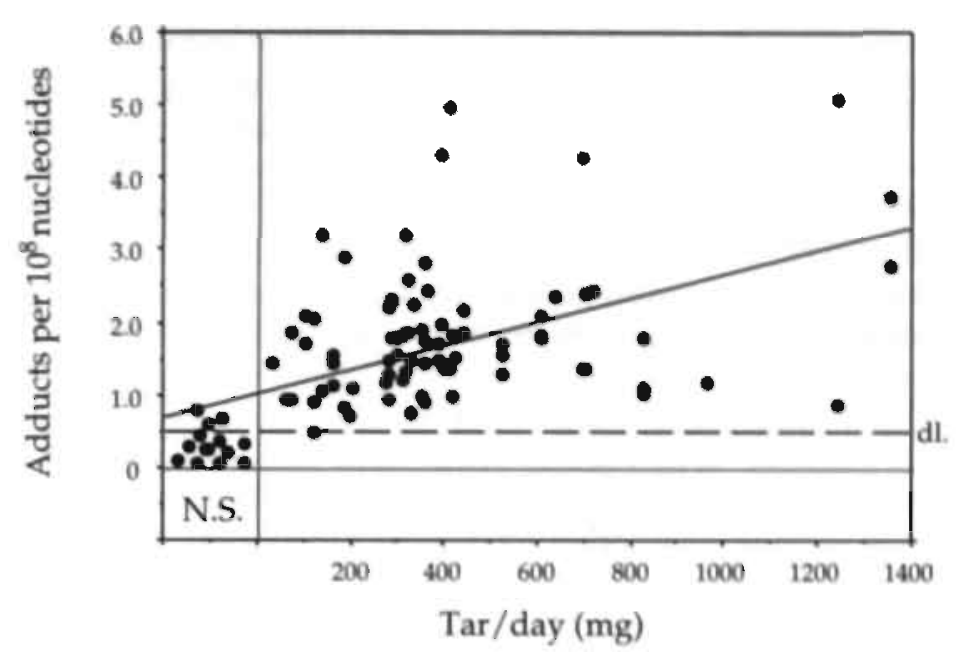

Figure 3. Linear regression between aromatic DNA adducts in MNC of smoking volunteers (AMSstudy population) determined by NP1 enriched ${ }^{32} \mathrm{P}$-postlabeling. (Adducts per $10^{8} \mathrm{nt}$ ) and daily exposure to cigarette-tar ( $\mathrm{mg} /$ day) (excluding nonsmokers: $\mathrm{r}=0.31, \mathrm{P}=0.005, \mathrm{n}=78$; Including nonsmokers: $r=0.50, P=0.0001, n=93$ ). The dashed line indicates the limit of detection (dl.)

In $\mathrm{MNC}$ a significant linear relationship was observed between exposure to cigarette tar and the levels of aromatic DNA adducts. This is in line with previous observations of a relationship between DNA adducts in lung tissue and the amount of cigarettes smoked per day $(6,24,39)$. Adduct levels in BAL-cells, predominantly alveolar macrophages, were higher than DNA adduct levels in WBCsubpopulations. Thus, BAL-cells may represent a more sensitive surrogate tissue, because at low levels of inhalatory exposure, aromatic DNA adducts in BAL cells may still be detectable and at the same time DNA adduct levels in peripheral WBC are below the detection limit of the techniques currently in use. On the contrary, no significant correlations were found between DNA adduct levels in BAL-cells and exposure to cigarette smoke, but as recently demonstrated by Van Schooten et al. (40) the absence of a quantitative relationship could be due to saturation of adduct formation at high exposure levels. BAL cells are directly and highly exposed to cigarette smoke and in the present study BAL cells of heavy smokers were used (>20 $\mathrm{cig}$ /day), therefore saturation may have occurred. Aromatic-DNA adduct levels in BAL were positively correlated with age. In lung tissue, Tang et al. (41) recently found an inverse relationship between adduct levels and age. In other studies concerning lung tissue, no influence of age was reported $(6,24,39)$. Therefore, until now a possible relationship between DNA adduct levels in BAL cells and lung tissue remains unclear and should be further investigated.

It has been reported that "P-postlabeling with NP1 enrichment detects predominantly PAH, whereas butanol enrichment detects in addition to PAH also aromatic amines and nitroaromatics $(5,17)$. In all cell types that were examined in 
the present study, adduct levels were higher by butanol as compared with NP1 enrichment, which was also found by Binkova et al. (18) in environmentally exposed individuals. This suggests that the formation of DNA adducts by aromatic amines or tobacco specific nitroaromatics is substantial, because differences between these two methods were 6-fold in MNC and 2-fold in BAL-cells. However, other studies report the opposite for white blood cells (42). In the present study, aromatic-DNA adducts were detected in WBC of nonsmokers by butanol enrichment, but not by the NP1method. Apparently, for reasons unknown, the NP1-method seems to be more specific for tobacco smoke exposure. In BAL-cells, but not in MNC, a significant correlation was observed between NP1 and butanol enrichment. This can be explained by the fact that DNA adducts in BAL-cells mainly represent exposure by inhalation, although in BAL cells no clear dose-response with smoking was observed. On the other hand, DNA adduct levels in WBC may originate from different sources such as ingestion of food-borne carcinogens. These differences in exposure source could also explain the absence of a relationship between smoking behavior and DNA adduct levels in MNC when butanol enrichment was applied.

Our results show that mononuclear cell fractions should be used for monitoring exposure to PAH. Application of BAL-cells might represent a more sensitive and specific surrogate for inhaled PAH, but further studies are necessary.

\section{Acknowledgments}

Dr. J.G.M. van Engelen and Dr. R.P.F. Schins are gratefully aknowledged for their assistance.

\section{References}

1. Denissenko, M.F., Pao, A., Tang, M., Pfeifer, G.P. (1996) Preferential formation of benzo[a]pyrene adducts at lung cancer mutational hotspots in P53, Science. 274, 430432 .

2. Hall, M., Grover, P.L.(1990) Polycyclic aromatic hydrocarbons: metabolism, activation, tumor-initiation. In Cooper, C.S., Grover, P.L. (ed) Chemical carcinogenesis and mutagenesis. Raven Press, New York, vol. 1, pp. 327-372.

3. Ross, J., Nelson, G.B., Wilson, K.H., Rabinowitz, J.R., Galati, A., Stoner, G.D., Nesnow, $\mathrm{S}$., Mass, M.J.(1995) Adenomas induced by PAH in strain A/J mouse lung correlates with time integrated DNA adduct levels. Cancer Res., 55, 1039-1044.

4. Nesnow, S., Ross, J.A., Stoner, G.D., Mass, M.J. (1995) Mechanistic linkage between DNA adducts, mutations in oncogenes and tumorigenesis of carcinogenic environmental polycyclic aromatic hydrocarbons in strain A/J mice, Toxicol.. 105, 403413.

5. Whong, W.-Z., Stewart, J.D., Ong, T. (1992) Comparison of DNA adduct detection between two enhancement methods of the ${ }^{32} \mathrm{P}$-postlabeling assay in rat lung cells. Mutation Res., 283, 1-6.

6. Phillips, D.H., Hewer, A., Martin, C.N., Garner, R.C., King, M.M. (1988)Correlation of DNA adduct levels in human lung with cigarette smoking. Nature, 336, 790-792. 
7. Savela, K., Hemminki, K.(1991) DNA adducts in lymphocytes and granulocytes of smokers and non-smokers detected by ${ }^{32}$ P-postlabeling. Carcinogenesis. 12, 503-508.

8. Holz, O., Krause, Th., Scherer, G., Schmidt-Preuss, U., Rüdiger, H.W.(1990) 32p. postlabeling analyses of DNA adducts in monocytes of smokers and passive smokers. Int. Arch. Occup. Environ. Health, 62, 299-303.

9. Santella, R.M., Grinberg-Funes, R.A., Lan Young, T., Dickey, C., Nath Singh, V., Wenwang,L., Perera, F.P.(1992) Cigarette smoking related polycyclic aromatic hydrocarbon-DNA adducts in peripheral mononuclear cells. Carcinogenesis, 13, 20412045.

10. Van Maanen, J.M.S., Maas, L.M., Hageman, G., Kleinjans, J.C.S., Van Agen, B.(1994) DNA adduct and mutation analysis in White blood cells of smokers and non-smokers. Environ. Mol. Mutagenesis, 24, 46-50.

11. Okano, P., Miller, H.N., Robinson, R.C., Gelboin, H.V.(1979) Comparison of benzo[a]pyrene and (-)-trans-7,8-dihydroxy-7,8-dihydrobenzo[a]pyrene metabolism in human blood monocytes and lymphocytes. Cancer Res., 39, 3184-3193.

12. Knudsen, L.E., Ryder, L.P., Wasserman, K. (1992) induction of DNA repair synthesis in human monocytes/B-lymphocytes compared with T-lymphocytes after exposure to Nacetoxy- $\mathrm{N}$-acetylaminofluorene and dimethylsulfate in vitro. Carcinogenesis, 13, 12851287.

13. Izzotti, A., G.A. Rossi, M. Bagnasco, S. de Flora (1991) Benzo[a]pyrene diolepoxideDNA adducts in alveolar macrophages of smokers. Carcinogenesis, 12, 1281-1285.

14. De Flora, S., A. Izotti, F. D'Agostini, G.A. Rossi and R.M. Balansky (1993) Pulmonary alveolar macrophages in molecular epidemiology and chemoprevention of cancer.

Environ. Health. Perspect, 99, 249-252.

15. Bøyum, A.(1976) Isolation of lymphocytes, granulocytes and macrophages. Scand. L Immunol. 5, 9-15.

16. Reddy, M.V., Randerath, K.(1986) Nuclease P1 mediated enhancement of sensitivity of $32 \mathrm{P}$-postlabeling test for structually diverse DNA-adducts. Carcinogenesis, 7, 15431551.

17. Gallagher, J.E., Jackson, M.A., George, M.H., Lewtas, J., Robertson, I.G.C. (1989) Differences in detection of DNA adducts in the ${ }^{32} \mathrm{P}$-postlabeling assay after either 1butanol extraction or Nuclease P1 treatment. Cancer Lett., 45, 7-12.

18. Binkova, B., Lewtas, J., Miskova, I., Lenicek, J., Sram, R.(1995) DNA adducts and personal air monitoring of carcinogenic polycyclic aromatic hydrocarbons in an environmentally exposed population. Carcinogenesis, 16, 1037-1046.

19. Szyfter, K., Hemminki, K., Szyfter, W., Szmeja, Z., Banaszewski, J., Yang, K.(1994) Aromatic DNA adducts in larynx biopsies and Leukocyfes. Carcinogenesis, 15, 21952199.

20. Perera, F.P., Tang, D.I., O'Neill J.P.O, Bigbee, W.L., Albertini, R.J., Santella, R., Ottman, R., Tsai, W.Y., Dickey, C., Mooney, L.A., Savela, K., Hemminki, K. (1993) HPRT and glycophorin A mutations in foundry workers: relationship to PAH exposure and to PAH-DNA adducts. Carcinogenesis, 14, 969.973.

21. van Schooten, F.J., Hillebrand, M.J.X., van Leeuwen, F.E., Lutgerink, J.T., var, Zandwijk, N., Jansen, H.M., Kriek, E.(1990) Polycyclic aromatic hydrocarbon-DNA adducts in lung tissue from lung cancer patients. Carcinogenesis, 11, 1677-1681.

22. Mustonen, R., Hemminki, K.(1992) 7-Methylguanine levels in DNA of smokers' and non-smokers" total white biood cells, granulocytes and lymphocyres. Carcinogenesis, $13,1951-1955$.

23. Jahnke, G.D., Thompson, C.L., Walker, M.P., Galligher, J.E., Lucier, C.W., DiAugustine, R.P.(1990) Multiple DNA adducts in lymphocytes, of smokers, and nonsmokers determined by ${ }^{32} \mathrm{P}$-postlabeling analysis. Carcinogenesis, 11, 205-211.

24. Phillips, D.H., Schoket, B., Hewer, A., Bailey, E., Kostic, S., Vincze, I.(1990) Irffluence of cigarette smoking on the levels of DNA adducts in human bronchial epithelium and white blood cells. Int. I. Cancer, 46, 569-575.

25. Liou, S-H., Jaçobson-Kram, D., Poirier, M.C., Nguyen, D., Strickland, P.T., Tockman, M.S.(1989) Biological monitoring of fire-fighters: sister chromatin exchange and 
polycyclic aromatic hydrocarbon DNA adducts in peripheral blood cells. Cancer Res., 49, 4929-4935.

26. Rothman, N., Poirier, M.C., Haas, R.A., Correa-Villasenor, A., Ford, P., Hansen, J.A., OToole, T., Strickland, P.T.(1993a) Association of PAH DNA adducts in peripheral white blood cells with dietary exposure to PAH. Environ. Health Perspect., 99, 265-267.

27. Rothman, N., Correa-Villasenor, A., Ford, D.P., Poirier, M.C., Haas, R.A., Hansen, J.A., O'Toole, T., Strickland, P.T.(1993b) Contribution of occupation and diet to white blood cell PAH DNA adducts in wildland firefighters. Cancer Epidemiol., Biomarkers \& Prev. 2, 341-347.

28. Strickland, P.T., Rothman, N., Baser, M.E., Poirier, M.C.(1991) Polycyclic aromatic hydrocarbon DNA adduct load in peripheral blood cells. Contribution of multiple exposure source. In Vanderlaan,M.(eds) Immunoassays for trace chemical analysis , ACS Symposium Series, American Chemical Society, Washington D.C., vol. 451, pp 257-263.

29. ØvebrØ, S., Haugen, A., Fjeldstadt,P.E., Hemminki,K., Szyfter,K.(1990) Biological monitoring of exposure to polycyclic aromatic hydrocarbons in an electrode paste. plant. L. Occup. Med., 36, 303-310.

30. Herbert, R., Marcus, M., Wolff, M.S., Perera, F.P. Andrews, L., Godbold, J.H., Rivera, M. Stefanidis, M., Lu, X-Q., Landrigan, P.J., Santella, R.M.(1990) Detection of adducts in DNA of white blood cells of roofers by ${ }^{32} \mathrm{P}$-postlabeling. Relationship of adduct levels to measures of PAH. Scand. I. Work Environ. Health, 16, 135-143.

31. Van Maanen, J.M.S., Moonen, E.J.C., Maas, L.M., Kleinjans, J.C.S., van Schooten, F.J. (1994) Formation of aromatic DNA adducts in white blood cells in relation to urinary excretion of 1-hydroxypyrene during consumption of grilled meat. Carcinogenesis, 15, 2263-2268.

32. Gupta, R.C., Early, K., Sharma, S. (1988) Use of human peripheral blood lymphocytes to measure DNA binding capacity of chemical carcinogens.Proc. Natl. Acad. Sci. U.S.A. 85, 3513-3517.

33. Stierum, R.H., van Herwijnen, M.H.M., Maas, L.M., Hageman, G.J., Kleinjans, J.C.S. (1994) Measurement by ${ }^{32} \mathrm{P}$-postlabeling of $( \pm$ ) anti-benzo[a]pyrene diolepoxide-N2deoxyguanosine adduct persistence in unstimulated human peripheral blood lymphocytes. Mutat. Res., 325, 31-37.

34. Celotti, L., Ferraro, P., Furlan, D., Zanesi, N., Pavanello, S. (1993) DNA repair in human lymphocytes treated in vitro with $( \pm)$-anti- and $( \pm)$-syn-benzo[a]pyrene diol epoxide. Mutat. Res., 294, 117-126.

35. Nowak, D., Schmidt-Preuss, U., Jörres, R., Liebke, F., Rüdiger, H.W.(1988) Formation of DNA adducts and water soluble metabolites of benzo[a]pyrene in human monocytes is genetically controlled. Int. I. Cancer, 41, 169-173.

36. Nowak, D., Meyer, A., Schmidt-Preuss, U., Gatzemeier, U., Magnussen, H., Rüdiger, H.W.(1992) Formation of benzo[a]pyrene-DNA adducts in blood monocytes from lung cancer patients with a familial history of lung cancer. I. Cancer Res.Clin. oncol., 118, 6771.

37. Hawke, L.J., Farrell, G.C. (1986) Increased binding of benzo[alpyrene metabolites to lymphocytes from patients with lung cancer. Cancer Lett., 30, 89-297.

38. Li, D., Wang, M., Cheng, L., Spitz, M.R., Hittelman, W.N., Wei, Q. (1996) In vitro induction of benzo(a)pyrene diol epoxide-DNA adducts in peripheral lymphocytes as a susceptibility marker for human lung cancer. Cancer Res., 56, 3638-3641.

39. Cuzick, J., Routledge M.N., Jenkins, D., Garner R.C. (1990) DNA adducts in different: tissues of smokers and non-smokers. Int. J. Cancer, 45, 673-678.

40. Van Schooten, F.J., Godschalk, R.W.L., Breedijk, A., Maas, L.M., Kriek, E., Sakai, H., Wigbout, G., Baas, P., Van 't Veer, L., Van Zandwijk, N. (1997) ${ }^{32}$ P-postlabeling of aromatic DNA adducts in white blood cells and alveolar macrophages of smokers: saturation at high exposures, Mut. Res. 378, 65-75

41. Tang, D., Santella, R.M., Blackwood, A.M., Young, T.L., Mayer, J., Jaretzki, A., Grantham, S., Tsai, W.Y., Perera, F.P. (1995) A molecular epidemiological Case -control study of Lung cancer. Cancer Epidemiol., Biomarkers \& Prev. 4, 341-346. 
42. Savela, K., Hemminki, K. (1993) Analysis of cigarette smoke induced DNA adducts by butanol extraction and nuclease P1 enhanced ${ }^{32}$-p-postlabeling in human lymphocytes and granulocytes. Environ. Health Perspect, 101, 145-150. 


\title{
32P-Postlabeling of aromatic DNA adducts in white blood cells and alveolar macrophages of smokers: saturation at high exposures
}

\author{
F.J.van Schooten ${ }^{1}$, R.W.L. Godschalk ${ }^{1}$, A. Breedijk², L.M. Maas¹, E. Kriek ${ }^{3}$, H. \\ Sakai $^{4}$, G. Wigbout 4 , P. Baas', L. van 't Veer ${ }^{2}$, N. Van Zandwijk ${ }^{4}$ \\ 1 Department of Health Risk Analysis and Toxicology, \\ University of Maastricht, Maastricht, The Netherlands \\ 2 Department of Molecular Pathology, \\ 3 Department of Molecular Carcinogenesis, and \\ 4 Department of Chest Oncology \\ The Netherlands Cancer Institute,Amsterdam, The Netherlands
}

Mutation Research, vol. 378 pp 65-75, 1997

\begin{abstract}
DNA adducts may serve as a molecular dosimeter of exposure to cigarette smoke associated carcinogens such as polycyclic aromatic hydrocarbons (PAH). Target tissues for cigarette smoke induced carcinogenesis are rarely accessible, therefore peripheral blood cells or cells obtained by broncho-alveolar lavage (BAL) may be used as surrogate sources of exposed DNA. However, the relation between cigarette smoke exposure and aromatic-DNA adducts in white blood cells and BAL-cells is still unclear. In this study, we examined DNA adduct formation in lymphocytes and BAL-cells in several populations of smoking individuals by means of ${ }^{32} \mathrm{P}$ postlabeling. Significant correlations between the amount of cigarettes smoked per day and the level of aromatic DNA adducts were found in lymphocytes. In BAL. cells, DNA adduct levels were associated with age $(P=0.05)$ and gender $(P=0.10)$ after adjustment for smoking behavior. Adduct formation leveled off at higher exposure levels, suggesting less efficient adduct formation; decreases in the formation of adducts per unit of exposure were found in lymphocytes $\left(r_{s}=-0.80\right.$, $\mathrm{P}<0.001)$ and $\mathrm{BAL}$-cells $\left(\mathrm{r}_{\mathrm{s}}=-0.72, \mathrm{P}<0.001\right)$. To assess intra-individual variation in adduct levels at constant smoking behavior, sampling was repeated after a period of two and six months. In lymphocytes, repeated measurements with an interval of 2 months were highly correlated $(r=0.84 ; \mathrm{P}=0.009 ; \mathrm{n}=8)$, whereas repeated measurements with an interval of 6 months showed no correlation ( $r=0.30 ; \mathrm{P}=0.27$; $\mathrm{n}=16$ ). Repeated measurements in BAL-cells showed a significant correlation after 6 months ( $r=0.68 ; P=0.03 ; n=10$ ). Furthermore, in a group of occupationally exposed aluminum workers, adduct levels in total white blood cells were correlated with the average concentrations of PAH in the ambient air of workers who smoked cigarettes, whereas in nonsmokers no such a relationship was found. We conclude that cigarette smoking may directly or indirectly influence DNA adduct levels and saturation of DNA adduct formation may occur, leading to nonlinear dose-response relationships.
\end{abstract}




\section{Introduction}

Molecular epidemiologists need sensitive tools to assess environmental or occupational exposure to carcinogens such as polycyclic aromatic hydrocarbons (PAH). Measurements of the external or internal dose of PAH are usually not satisfactory, since these parameters do not represent ultimate carcinogenic metabolites at critical sites. Therefore, carcinogen-DNA adducts are used as indicators. for the biologically effective dose (1). Several techniques have been developed to study PAH-DNA adducts, of which the 32P-postlabeling assay is most commonly applied. This technique is sufficiently sensitive to detect low levels of adducts in small quantities of DNA, and is applicable to unknown adducts that may be formed upon exposure to complex chemical mixtures such as cigarette smoke. In most organs which are susceptible towards cigarette smoke induced diseases (e.g. lung, cervix, larynx and heart), relationships were found between aromatic DNA adduct levels and daily cigarette smoking. In organs which are not considered to be associated with cigarette smoke induced diseases (e.g. breast and liver) no such relationships were observed (2). However, susceptible tissues can rarely be obtained and more accessible sources of exposed DNA have been analyzed in most human studies. For instance, DNA of peripheral white blood cells (WBC) was analyzed as a surrogate in smoking individuals (3-5). In these studies, large interindividual variation in aromatic-DNA adduct levels was observed and no clear differences between smokers and non-smokers were found. Studies with isolated subpopulations of WBC seemed more promising, but were still not conclusive (6-9). To overcome some of the problems encountered by the use of WBC, other sources of non-target DNA have been studied. Izotti et al. (10) and De Flora et al. (11) concluded that the detection of carcinogen-DNA adducts in pulmonary alveolar macrophages (PAM), obtained by broncho-alveolar lavages (BAL), might represent a specific biomonitoring tool for inhaled PAH. Also in these studies considerable variations in DNA adduct levels were reported. In order to further validate DNA adducts as a measure of exposure, it is necessary to have sufficient information on dose-response relationships and inter- and intra-individual variations. Additionally, we and other investigators found that cigarette smoking has a synergistic effect on DNA adduct formation in combination with occupationa! exposure to $\mathrm{PAH}(12,13)$.

In the present study we examined DNA adduct formation in two types of surrogate cells, peripheral blood lymphocytes and BAL-cells of smoking individuals, and determined dose-responses. To assess the intra-individual variation, lymphocytes and BAL-cells were resampled at 2 and at 6 months. To study the influence of smoking on dose-responses, the relationship between exposure and subsequent aromatic-DNA adduct formation was examined in total WBC of smoking and nonsmoking aluminum workers, which were exposed to high concentrations of PAH in the ambient air. 


\section{Materials \& Methods}

\section{Study-populations}

This study was performed in two separate populations of cigarette smoking individuals and a third group of occupationally exposed aluminum workers. The characteristics of the two groups of smokers are presented in Table I.

Table I: Description of study populations I and II.

\begin{tabular}{lll}
\hline & Population Ia & Population II $^{\mathrm{b}}$ \\
\hline Number & 13 & 41 \\
Male/Female & $4 / 9$ & $14 / 27$ \\
Age & $41 \pm 7$ & $43 \pm 10$ \\
Cigarettes/day & $29 \pm 16$ & $27 \pm 13$ \\
Tar (mg)/ day & $266 \pm 342(n=7)$ & - \\
Adducts in Lymphocytes $\quad 2.8 \pm 0.8(n=13)$ & $1.5 \pm 0.1(n=41)$ \\
$\quad$ Resampling & $1.7 \pm 0.2(n=8)$ & $2.5 \pm 0.3(n=16)^{n}$ \\
Adducts in BAL-cells & $7.7 \pm 1.4(n=9)$ & $5.9 \pm 0.5(n=28)$ \\
\multicolumn{1}{r}{ Resampling } & $9.9 \pm 2.8(n=4)$ & \\
\hline
\end{tabular}

a: Repeated sampling after 2 months

b: Repeated sampling after 6 months

H: $\mathrm{P}<0.05$, compared to first sampling

Adducts in lymphocytes and BAL-cells were analyzed as described below. In study population I, 4 male (age: $40 \pm 5$ years) and 9 female ( $42 \pm 7$ years) volunteers were included. Blood and BAL-cells were sampled in October 1994 and resampled in December 1994. Study population $\Pi$ consisted of 14 male ( $40 \pm 9$ years) and 27 female (45 \pm 10 years) volunteers. Blood and BAL-cells were obtained in February-April 1995 and were resampled in August-September 1995. As controls 5 nonsmokers (age: $30 \pm 4$ years, 3 males and 2 females) were included, from these persons only lymphocytes were obtained. The study was approved by the medical ethical commission of the Netherlands Cancer Institute and informed consent was obtained in all cases. Study population III was a subset of 105 occupationally exposed workers ( $41 \pm 8$ years), employed in a primary aluminum production plant consisting of three highly exposed groups; 7 workers from the pot-relining department (0.9-1709 $\mu \mathrm{g}$ $\mathrm{PAH} / \mathrm{m}^{3}$; smokers vs. nonsmokers: $\left.5 / 2\right) ; 6$ workers from the anode factory (1.1-854 $\left.\mu \mathrm{g} \mathrm{PAH} / \mathrm{m}^{3} ; 1 / 5\right)$ and 16 workers from the bake oven department $(3.0-107 \mu \mathrm{g}$ $\left.\mathrm{PAH} / \mathrm{m}^{3} ; 6 / 10\right)$, a moderately exposed group of 14 workers from the electrolysis department $\left(0.3-4.6 \mu \mathrm{gAH} / \mathrm{m}^{3} ; 5 / 9\right)$, and a low exposure group of 14 workers from the foundry department $\left(0.1-3.8 \mu \mathrm{g} \mathrm{PAH} / \mathrm{m}^{3} ; 7 / 7\right)$. Details on the study design and the results of DNA adduct analyses and ambient air monitoring have been reported previously (12). In the present study, we performed additional statistical analyses to further investigate the relation between PAH exposure and DNA adduct formation. 
All participants answered a comprehensive questionnaire about their smoking habits.

\section{Isolation of lymphocytes}

Peripheral blood was obtained by venapuncture into EDTA-tubes. Lymphocytes were isolated by centrifugation on lymphoprep according to Bøyum (14). Lymphocytes were washed with PBS and frozen in $-20^{\circ} \mathrm{C}$ until DNA isolation.

\section{Broncho-alveolar lavage and obtaining pulmonary alveolar macrophages}

Bronchoscopy was performed under local anesthesia (lidocaine). The bronchoscope was placed into the right middle lobe bronchus and $180 \mathrm{ml}$ of sterile saline $\left(37^{\circ} \mathrm{C}\right)$ was instilled in nine aliquots of $20 \mathrm{ml}$ each. The dwell time was about 3 minutes. BAL fluid was directly collected in plastic tubes and placed on ice. Cells were counted and after centrifugation $\left(4{ }^{\circ} \mathrm{C}, 4000 \mathrm{rpm}, 10\right.$ minutes), the cell-pellet was stored at $-70^{\circ} \mathrm{C}$ until DNA isolation.

\section{DNA isolation}

Lymphocytes and BAL-cells were lysed with $2.5 \mathrm{ml} \mathrm{SDS} / \mathrm{NEP}(75 \mathrm{mM} \mathrm{NaCl}, 25 \mathrm{mM}$ EDTA, $50 \mu \mathrm{g} / \mathrm{ml}$ or $1 \mathrm{mg} / \mathrm{ml}$ proteinase $\mathrm{K}$ respectively, $1 \%$ SDS) and incubated overnight at $37{ }^{\circ} \mathrm{C}$. DNA was extracted with phenol:chloroform: isoamylalcohol $(25: 24: 1, \mathrm{v} / \mathrm{v} / \mathrm{v})$ and chloroform:isoamylalcohol (24:1). The DNA was precipitated with two volumes of cold ethanol after addition of $1 / 30$ volume $3 \mathrm{M}$ sodium acetate, $\mathrm{pH} 5.3$, and washed with $70 \%$ ethanol. DNA was dissolved in $5 \mathrm{mM}$ Tris and RNase T1 $(50 \mathrm{U} / \mathrm{ml})$ and RNase $\mathrm{A}(100 \mu \mathrm{g} / \mathrm{ml})$ were added, followed by 30 minutes of incubation at $37^{\circ} \mathrm{C}$. The solutions were extracted with chloroform:isoamylalcohol (24:1). DNA was precipitated from the aqueous phase with cold ethanol, washed with $70 \%$ ethanol and dissolved in $2 \mathrm{mM}$ Tris, $\mathrm{pH} 7.4$. Concentration and purity were determined spectrophotometrically by absorbance at 230,260 and $280 \mathrm{~nm}$. The final volume was adjusted to achieve a DNA-concentration of $2 \mathrm{mg} / \mathrm{ml}$.

\section{${ }^{32} P$-postlabeling}

The ${ }^{32} \mathrm{P}$-postlabeling assay was performed as described by Reddy and Randerath (15) with some modifications. DNA $(10 \mu \mathrm{g})$ was digested using micrococcal endonuclease $\left(0.4\right.$ Units) and spleen phosphodiesterase $(2.8 \mu \mathrm{g})$ for 3 hours at $37^{\circ} \mathrm{C}$. Subsequently, half of the digest was treated with nuclease P1 $(6.3 \mu \mathrm{g})$ for 40 minutes at $37^{\circ} \mathrm{C}$. The modified nucleotides were labeled with $\left[\gamma^{32} \mathrm{P}\right]-\mathrm{ATP}(50 \mu \mathrm{Ci} /$ sample) by incubation with T4-polynucleotide kinase (5.0 Units) for 30 minutes at $37^{\circ} \mathrm{C}$. $\left[\gamma^{32} \mathrm{P}\right]-\mathrm{ATP}$ was synthesized in the laboratory using carrier free ${ }^{32} \mathrm{P}$ (Dupont, Brussels). NP1efficiency and ATP-excess were checked with an aliquot of the NP1 treated fraction by one dimensional chromatography on poly(ethyleneimine) (PEl)-cellulose sheets from Merck, Germany (solvent: $0.12 \mathrm{M} \mathrm{NaH}_{2} \mathrm{PO}_{4} \mathrm{pH}$ 6.8). Radiolabeled adduct nucleotide biphosphates were separated by chromatography on PEI-cellulose sheets from Machery Nagel (Germany). The following solvent systems were used: D1, $1 \mathrm{M}$ $\mathrm{NaH}_{2} \mathrm{PO}_{4} \mathrm{pH} 6.5 ; \mathrm{D} 2,8.5 \mathrm{M}$ urea, $5.3 \mathrm{M}$ lithium formate $\mathrm{pH} 3.5 ; \mathrm{D} 3,1.2 \mathrm{M}$ lithium chloride, $0.5 \mathrm{M}$ Tris, 8.5 ure'a $\mathrm{pH} 8.0 ; \mathrm{D} 4,1.7 \mathrm{M} \mathrm{NaH}_{2} \mathrm{PO}_{4} \mathrm{pH}$ 6.0. In each experiment, 
3 standards of $\left[{ }^{3} \mathrm{H}\right] \mathrm{BPDE}$ modified DNA with known modification levels ( 1 per $10^{7}$, $10^{8}, 10^{9}$ nucleotides) were run parallel for quantification purposes. Quantification was performed by using phosphor-imaging technology (Molecular Dynamics.TM., Sunnyvale, CA, USA) with a detection limit of 1 adduct per $10^{*}$ nucleotides. The remaining half of the digest was used to determine the final amount of DNA in the assay; the normal nucleotides were labeled with [ $\gamma-32 \mathrm{P}]-\mathrm{ATP}(15 \mu \mathrm{Ci} / \mathrm{sample})$ by incubation with $\mathrm{T} 4$-polynucleotide kinase (2.5 Units) for 30 minutes at $37^{\circ} \mathrm{C}$. Nucleotides were separated by one dimensional chromatography on PEI-cellulose sheets from Merck (solvent: $0.12 \mathrm{M} \mathrm{NaH}_{2} \mathrm{PO}_{4} \mathrm{pH}$ 6.8); samples with apparent protein or RNA contamination were discarded. A dAp standard (27.5 pmole/ $\mu$ l) was labeled in each experiment for quantification purposes. Each sample was analyzed in three independent experiments; the mean \pm SE inter-assay variation for lymphocytic DNA was $19.1 \pm 2.4 \%(n=53)$ and for BAL-DNA was $10.9 \pm 2.5 \%(n=18)$.

\section{Statistics}

Results are presented as mean \pm standard error of the mean. Linear regression models were applied to study the relationship between exposure and DNA adduct levels. Multiple regression analysis was carried out with DNA adduct levels as dependent and age, gender and smoking behavior as independent variables. Adduct levels per daily cigarette consumption were calculated (i.e. 'efficiency' of adduct formation) and analyzed by means of spearman-rank correlations. In aluminum workers, spearman-rank correlations between exposure to individual PAH and DNA adducts in WBC were determined. Values of $\mathrm{P}<0.05$ are considered as significant.

\section{Results}

\section{BAL-cell counts and cell characterization}

In study population I and II, the total amount of cells obtained by BAL were $14.5 \times 10^{7}\left( \pm 13.6 \times 10^{7}\right)$ and $9.85 \times 10^{7}\left( \pm 4.2 \times 10^{7}\right)$, respectively. The BAL-cells were predominantly PAM $(78.2 \pm 3.3 \%$; range: $68.4-96.9 \%$; $=10)$. Furthermore, bronchoepithelial cells ( $21.8 \pm 3.3 \%$; range: $3.1-34.5 \%)$ and, occasionally, lymphocytes and erythrocytes were present in the BAL.

\section{DNA adduct levels in lymphocytes and BAL-cells}

In lymphocytic- and BAL-DNA of smoking subjects, a diagonal radioactive zone (DRZ) was found by ${ }^{32} \mathrm{P}$-postlabeling, representing al large number of aromaticDNA addicts (Figure 1). No qualitative differences were seen between adduct patterns in lymphocytes and BAL-cells. In Table I the overall quantitative results of study population I and II are summarized. 


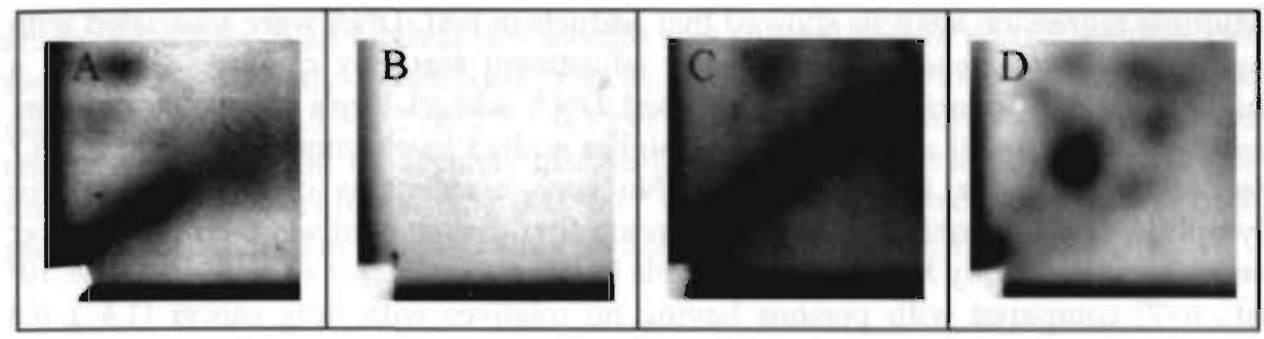

Figure 1. DNA adduct profiles determined by ${ }^{32} \mathrm{P}$-postlabeling. The origin is located at the lower left corner and was excised before analysis. Representative chromatograms of lymphocytic DNA of a smoker (A), of a non-smoker (B), BAL cell DNA of a smoker (C) and of $\left[{ }^{3} \mathrm{H}\right] \mathrm{BPDE}$ modified DNA (1 adduct per $10^{8}$ nucleotides) (D).

\section{DNA adduct levels and exposure to cigarette-smoke or cigarette-tar}

In first instance no clear association between the amount of daily cigarettes consumed and DNA adduct levels in lymphocytes could be observed in both groups of smokers (group I: first sampling $r=0.25, P=0.41, n=13$; group II: first sampling $r=0.02, P=0.92, n=41$ ). However, significant relations were observed when the nonsmoking controls were included in the analysis (Figure 2); correlation coefficients were low due to large interindividual variation in DNA adduct levels (group I: first sampling $\mathrm{r}=0.49, \mathrm{P}=0.04, \mathrm{n}=18$ and second sampling $\mathrm{r}=0.87, \mathrm{P}<0.001, \mathrm{n}=13$; group II: first sampling $r=0.38, P=0.01, n=46$ and second sampling $r=0.49, P=0.02, n=21)$. From a number of persons of group I the daily cigarette-tar exposure $(\mathrm{mg} / \mathrm{day})$ could be calculated and a better fit of the regression line was found (first sampling including nonsmokers $\mathrm{r}=0.76, \mathrm{P}=0.004, \mathrm{n}=12$ and second sampling including nonsmokers $\mathrm{r}=0.92, \mathrm{P}<0.001, \mathrm{n}=9$ ). At high exposures $(>200 \mathrm{mg}$ tar/day), adduct levels seemed to plateau and were found lower than expected from linearity, suggesting that saturation occurred. After splitting the study populations into light/moderate smokers $(\leq 20 \mathrm{cig} /$ day $)$ and heavy smokers $(>20 \mathrm{cig} /$ day $)$, correlations between adduct levels in lymphocytes and the amount of cigarettes smoked per day were improved in the group of non and light/moderate smokers (group I: first sampling $r=0.79, P=0.004, n=11$ and second sampling $r=0.98, P<0.001, n=9$; group II: first sampling $r=0.90, P<0.001, n=18$ and second sampling $r=0.94, P<0.001, n=10$ ). No correlations were found between smoking habits and aromatic DNA adducts in BAL-cells of mainly heavy smokers ( $>20 \mathrm{cig} /$ day) $(r=0.06 ; P=0.76)$. We observed a saturation of DNA adduct formation in both lymphocytes and BAL-cells suggesting less efficient adduct formation at higher doses. Expressing the adduct level per unit of exposure as a way of expressing the 'efficiency of adduct formation'; a decrease is observed when the dose is increased. In study population II, the adduct levels per cigarette decreased significantly in both lymphocytes (Spearman rank $r_{\mathrm{s}}=-0.80$, $\mathrm{P}<0.001)$ as well as BAL-DNA $\left(\mathrm{r}_{\mathrm{s}}=-0.72, \mathrm{P}<0.001\right)$ at higher doses (first sampling; Figure 3); in second sampling the same phenomenon was seen $\left(r_{\mathrm{s}}=-0.64, \mathrm{P}=0.006\right.$ respectively $r_{s}=-0.89, \quad P=0.001$ ). Furthermore, similar results were found for lymphocytes $\left(r_{s}=-0.61, P=0.01\right)$ and BAL-cells $\left(r_{s}=-0.72, P=0.01\right)$ of study population $I$. 
Multiple regression analysis showed that adducts in BAL-DNA were associated with age $(P=0.05)$ and gender $(P=0.10)$ after adjustment for daily cigarette smoking; a higher age was associated with increased DNA adduct levels (simple regression: $r=0.39, P=0.04, n=28)$ and women had higher adduct levels compared to males (6.7 vs. 4.9 adducts per $10^{8}$ nt., $\mathrm{P}=0.06$ ). No such associations could be found for lymphocytic DNA, only that persons having first degree relatives with lung cancer revealed significantly higher adduct levels in lymphocytes $\left(2.0 \pm 0.3\right.$ adducts per $10^{8}$ nt., $\mathrm{n}=7)$ compared with persons having no relatives with lung cancer $(1.4 \pm 0.8$ adducts per $10^{8}$ nucl, $\left.\mathrm{n}=31\right)(\mathrm{P}=0.017)$, although the amount of smoking and age in both groups were comparable.

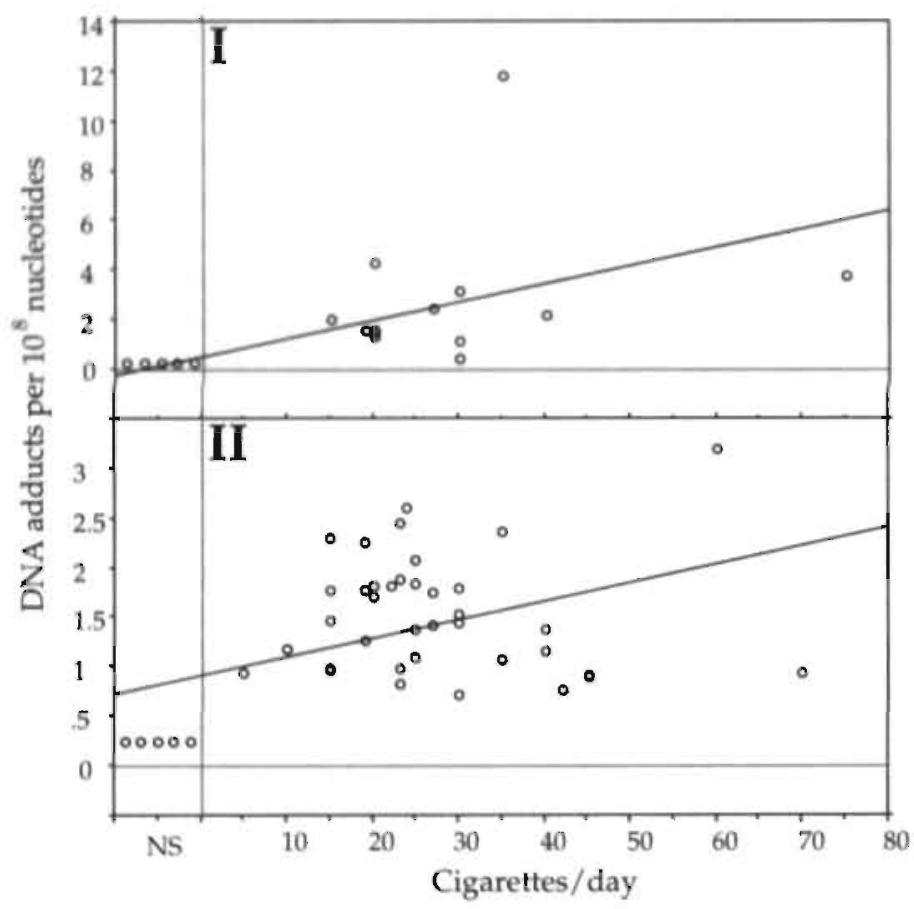

Figure 2. Relationship between the number of cigarettes smoked per day and aromatic-DNA adduct levels in lymphocytes of study population I (I) and study population II(II), Linear regression: $\mathrm{I}, \mathrm{r}=0.49$, $\mathrm{p}=0.04$; and II, $\mathrm{r}=0.38, \mathrm{p}=0.01$, NS, nonsmokers.

\section{Relationship between DNA adduct levels of repeated sampling}

To examine the intra-individual variation, from a number of persons a repeated sample of lymphocytes and BAL-cells was taken. In study population I from 8 persons a second sample of lymphocytes after 2 months was obtained; DNA adduct levels were comparable $(2.0 \pm 0.5$ versus $1.7 \pm 0.2 ; \mathrm{P}=0.25)$ and measurements were highly correlated ( $\mathrm{r}=0.84 ; \mathrm{P}=0.009$ ) (Figure 4$)$. Adduct levels in BAL-DNA had not significantly altered after two months $(6.2 \pm 2.0$ versus $9.9 \pm 2.8 ; P=0.30 ; n=4)$. In 
study population II an interval of 6 months was studied and 16 paired lymphocytes were not significantly interrelated $(r=0.30 ; P=0.27)$. Furthermore, levels increased significantly from $1.5 \pm 0.2$ to $2.5 \pm 0.3$ per $10^{8} \mathrm{nt}$. ( $\mathrm{P}=0.02$ ), although self-reported smoking behavior did not change. In BAL-DNA no difference in adduct levels was found after 6 months resampling $(6.0 \pm 0.7$ versus $5.9 \pm 0.7 ; \mathrm{P}=0.87 ; \mathrm{n}=10)$ and both measurements correlated significantly $(r=0.68 ; \mathrm{P}=0.029)$ (Figure 4).

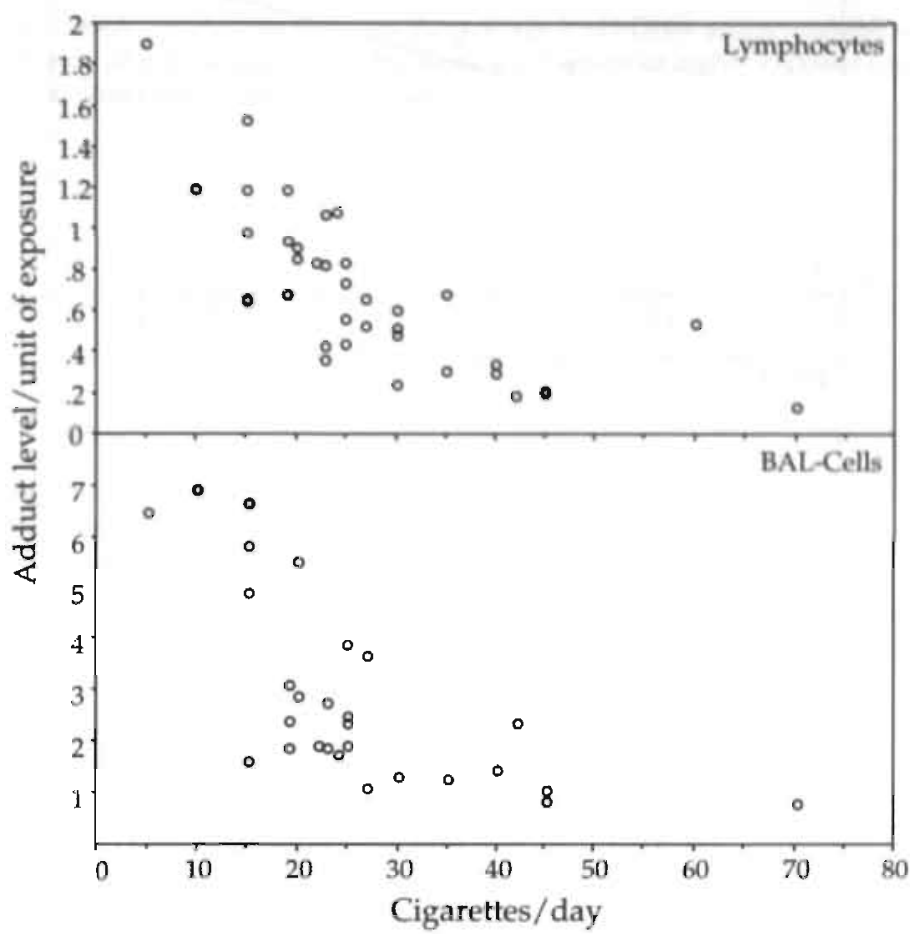

Figure 3. Relationship between the number of cigarettes smoked per day and adduct forming efficiency in lymphocytes and in BAL-cells (first sampling, study population II). Lymphocytes: $\mathbf{r}_{\mathrm{S}}=-$ $0.80, \mathrm{p}<0.001 ;$ BAL-cells: $\mathbf{r}_{\mathrm{S}}=-0.72, \mathrm{p}<0.01$.

Relationship between DNA adduct levels in lymphocytes and BAL-cells

No sigrificant correlation was found between DNA adduct levels in peripheral blood lymphocytes and DNA adducts in BAL-cells ( $r=0.19 ; \mathrm{P}=0.32$ ). Mean DNA adduct levels in BAL cells were 3 to 8 times higher compared to levels in lymphocytes. In population I during first sampling from 9 persons both lymphocytes and BAL-cells were obtained; adduct levels were respectively $3.1 \pm 1.2$ and $7.7 \pm 1.4$ adducts per $10^{8} \mathrm{nt}$. In second sampling 4 paired observations were obtained showing levels of $1.5 \pm 2.0$ resp. $9.9 \pm 2.8$ adducts per $10^{8} \mathrm{nt}$. In population II paired adduct levels in lymphocytes and BAL-DNA were $1.5 \pm 0.1$ resp. $5.9 \pm 0.5$ adducts per $10^{8} \mathrm{nt}$. 
$(\mathrm{n}=28)$. In second sampling 12 paired observations were obtained; $2.4 \pm 0.3$ resp. $5.6 \pm$ 0.6 adducts per $10^{8} \mathrm{nt}$. were found.

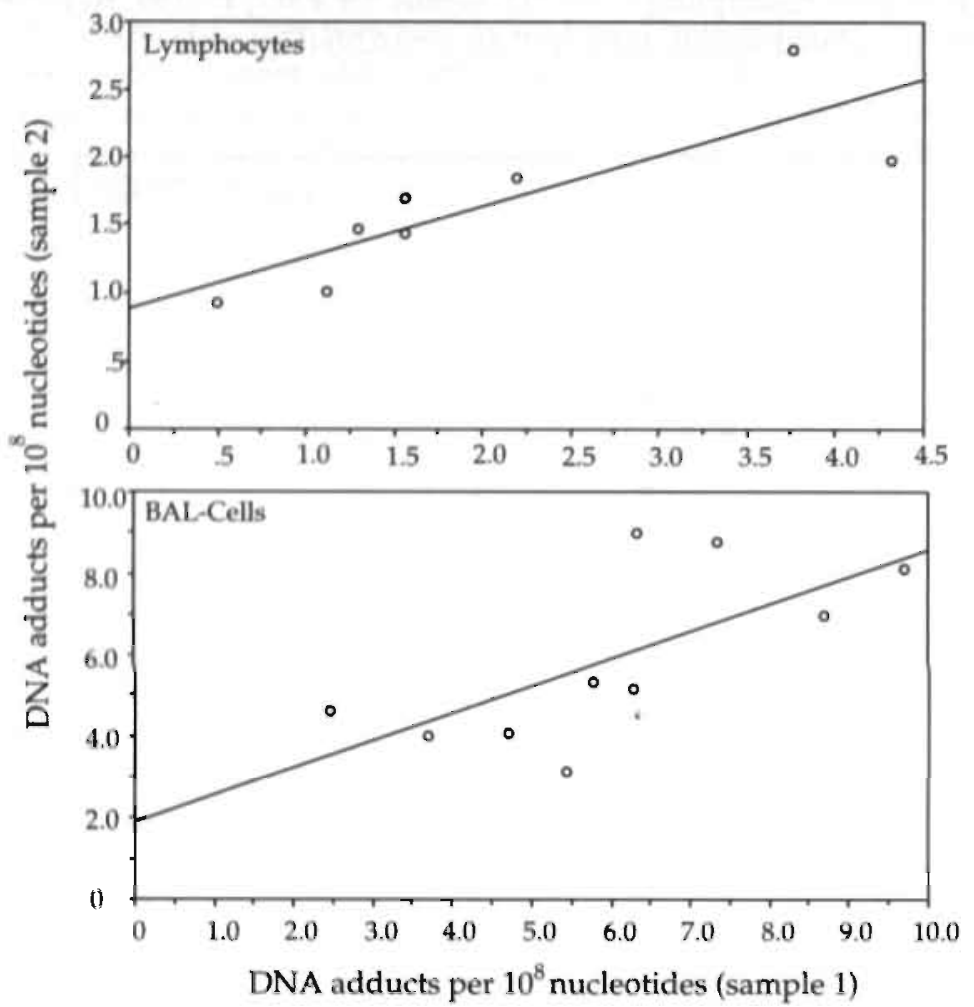

Figure 4. Relation between DNA adduct levels in lymphocytes and BAL-cells of repeated measurements. Upper panel: resampling of lymphocytes after an interval of 2 months $(r=0.84$, $p=0.009)$. Lower panel: resampling of BAL-cells after an interval of 6 months $(r=0.68, p=0.029)$.

\section{Effect of smoking on dose-responses in WBC of alumimum workers}

As shown in Table II, in highly exposed smoking aluminum workers (anode paste factory, bake oven, pot-relining), significant correlations between the average PAH-DNA adduct values and the average concentration of some individual PAH in the work atmosphere were found. In non-smoking subjects, no such relationships could be found. Interestingly, PAH in the ambient air that are known to give DNA adducts through the formation of reactive diol-epoxides, fluoranthene, benz[a]anthracene, chrysene, benzo[b]- and benzo[k]fluoranthene, benzo[a]pyrene, and also dibenz[a,h]anthracene and indeno[1,2,3-cd]pyrene, show strong correlations with average PAH-DNA adduct levels in WBC of smokers, whereas pyrene, a non-DNA binding PAH, does not show a relationship. Saturation of DNA 
adduct formation was found in WBC of both smoking and non-smoking workers, since DNA adduct levels reached a plateau in the highly exposed job categories (Figure 5A). Lower DNA adduct levels were found per $\mu \mathrm{g} / \mathrm{m}^{3}$ of $\mathrm{PAH}$ in the ambient air of the highly exposed groups compared to low exposure groups; the 'efficiency of adduct formation' seem to decrease at higher doses of exposure (Figure 5B).

Table II. Spearman rank correlations between the average PAH-DNA adduct values in WBC and the average concentration of individual PAH in the work atmosphere of highly exposed groups. (anode paste factory, bake oven and pot relining).

Aromatic

Hydrocarbon
Benzo[b]fluoranthene

+ Benzo[k]fluoranthene

Benzo[a]pyrene

Dibenz[a,h]anthracene

Benzo[ghi]perylene

Indeno[1,2,3-cd]pyrene

Total PAH

$\begin{aligned} & \text { Smokers } \\ & (\mathrm{n}=12)\end{aligned}$
$\mathrm{r}_{\mathrm{S}}$

\subsection{4}

0.300

0.628

0.561

0.700

Non-smokers
$(n=15)$
$r_{5} \quad P$

\section{$-0.077$}

0.068

0.023

$-0.082$

0.057

0.123

$0.384^{\mathrm{b}}$

0.006

0.694

0.524

0.646

0.573
0.143

0.040

0.012

0.026
0.229

0.181

0.021
0.393

0.405

0.454

0.385

0.420

0.331

0.174

0.215

0.278

0.471

$\mathrm{n}=$ number of persons, ${ }^{a} \mathrm{n}=5,{ }^{b} \mathrm{n}=6$

\section{Discussion}

In the present study, we obtained evidence for a saturation of DNA adduct formation in peripheral blood lymphocytes and BAL-cells at high exposure levels in smokers, and in WBC of occupationally exposed aluminum workers. Total adduct levels in lymphocytes were related to the amount of cigarettes smoked per day, moreover correlations were better in light/moderate smokers when compared to heavy smokers. No dose-response relationships were found in BAL-DNA, possibly because only BAL-cells of heavy smokers were studied. In this group interindividual variation was high and saturation might have occurred. Saturation is reflected by a significant decrease of the 'efficiency' of adduct formation at high levels of exposure to cigarette smoke, analogous to environmentally and occupationally exposed subjects as described by Lewtas et al. (16). DNA adduct levels in lymphocytes resampled after 2 months correlated significantly with DNA adduct levels of the first sampling. Although the level of exposure to cigarette smoke remained constant, adduct levels in lymphocytes after 6 months were significantly higher and no longer 
related to the first sampling. On the other hand, in BAL-DNA a significant relationship was found between the first sampling and that of 6 months later. Thus, DNA adduct levels in lymphocytes and BAL-cells reflect exposure to cigarette smoke associated carcinogens with relatively low intra-individual variation. The observed higher adduct levels in lymphocytes after six months might be related to seasonal influences which has been described earlier (17).

In $\mathrm{PAH}$ exposed laboratory rodents, DNA adducts were readily detected in organs as well as WBC by ${ }^{32} \mathrm{P}$-postlabeling $(18,19)$. Recently, DNA adducts in organs were linked to mutations in oncogenes and subsequent tumorigenesis $(19,20)$. Furthermore, significant correlations were found between PAH-DNA adducts in WBC and target organs (21). Such a relationship was also found for other carcinogens as methylating agents (22) and heterocyclic arylamines (23, 24). These results seem to justify the application of WBC as a molecular dosimeter for DNA adduct formation in internal organs and subsequent risk assessment.

In humans, smoking related aromatic-DNA adducts could be detected by ${ }^{32} \mathrm{P}-$ postlabeling in internal organs. Generally, the aromatic-DNA adduct concentrations in organs susceptible towards tobacco induced cancers (e.g. lung, cervix, bladder and pancreas) are related with daily cigarette smoking, $(2,25)$. In addition, a relationship between DNA adduct levels and smoking has been found in heart tissue, which may also be considered as a target tissue for tobacco-smoke; in a study with operable heart patients, significantly higher heart DNA adduct levels were found in persons suffering from severe coronary heart disease than those with no or mild coronary heart disease (26). A similar result was obtained in placental tissue showing DNA adduct levels to be related to smoking and inversely associated with birth weights of the infants (27). Conversely, in organs such as breast and liver which are not associated with tobacco induced disease, no quantitative relations between DNA adducts and smoking have been observed $(2,28)$. However, in breast tissue, qualitative differences in adduct patterns of smokers and non smokers were seen (28). The data suggest that tobacco-associated DNA damage in internal organs may be indicative of smoking related diseases. The present study indicates a quantitative relation between smoking and aromatic DNA adducts in lymphocytes and accordingly some epidemiological evidence is available that tobacco smoking is related to lymphoid cancers such as leukemia's (29), although the relation with specific compounds is unclear.

In the present study, a good correlation between the number of cigarettes smoked per day and aromatic-DNA adduct levels in peripheral blood lymphocytes was found, but at high doses (>20 cig/day) saturation seemed to occur. Analogously, in rats exposed to increasing concentrations of diesel exhaust, lung DNA adduct: levels determined by ${ }^{32} \mathrm{P}$-postlabeling did not increase (30). Reanalysis of DNA adduct data obtained from lung tissue of lung-cancer patients (31) and heart tissue of smoking patients undergoing open heart surgery (26), shows a deciine in the efficiency of DNA adduct formation at increasing levels of exposure to cigarette smoke (data not shown). This indicates that saturation may eventually occur in human tissues and dose-response curves will deviate from linearity, which we also found for lymphocytes and BAL-cells in the present study. 


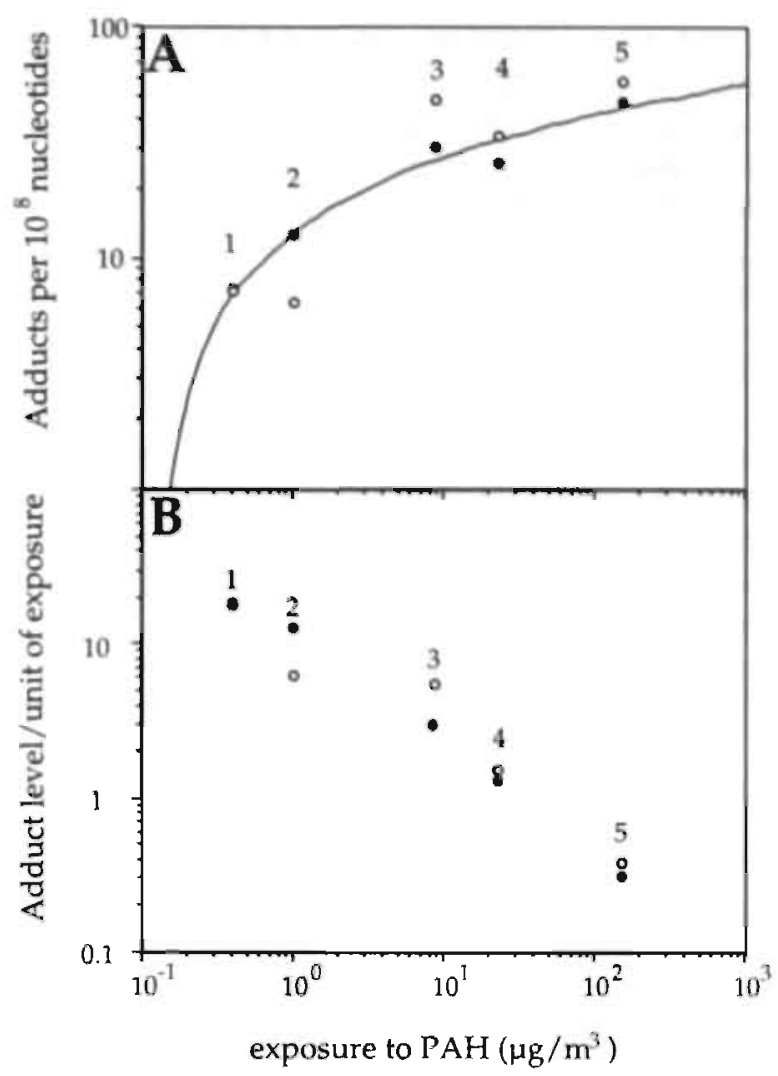

Figure 5. DNA adduct levels (A) and efficiency of DNA adduct formation (B) in (O) smoking and (O) non-smoking aluminum workers exposed to PAH. 1, foundry; 2, electrolysis; 3, bake oven; 4, anode factory; 5, pot-relining department.

Studies using the total fraction of WBC showed increased levels of aronnaticDNA adducts in smokers, but often DNA adduct levels were not significantly different from 'unexposed' controls $(3,5)$. The application of isolated lymphocytes (20-40\% of total WBC) is more promising, probably because in the most predominant WBC-subtype (granulocytes; $40-75 \%$ ) only low levels of DNA adducts have been found $(8,17)$. Thus, separation of WBC prior to analysis might be helpful to overcome the observed inter-and intra-individual variations. Indeed, in the present study intra-individual variation appeared to be low in isolated lymphocytes of smoking individuals and also in BAL-cells at a steady smoking behavior. Still, large interindividual variation was observed. Several studies indicate that this variation could be due to differences in DNA-repair $(32,33)$. Other studies suggest that this variation is genetically controlled (34) and that an increased carcinogen-DNA adduct 
formation may be one factor of a constitutionally enhanced lung cancer risk $(35,36)$. This phenomenon is also seen in the present study; higher adduct levels were found in smokers having first degree relatives suffering from lung cancer compared with those having no such relatives. We found in BAL-DNA higher adduct levels in females compared with males, which is in accordance with another study in which a similar result was found in lung DNA (37) and with epidemiological studies showing that women are at greater risk of tobacco-induced lung cancer $(38,39)$. Moreover, an increase of BAL-DNA adduct concentrations was found with increasing age, which may be explained by a decrease of DNA repair activities (32).

in aluminum workers, DNA adduct levels in WBC were related to exposure, but at the individual level no significant correlations were found (12). However, when the exposure groups were divided into smokers and nonsmokers, correlations were found between exposure to individual PAH and aromatic-DNA adducts in smokers. Interestingly, the two $\mathrm{PAH}(\mathrm{B}[\mathrm{a}] \mathrm{P}$ and benzo(b)fluoranthene) showing the strongest correlation with adduct levels were also responsible for the formation of DNA adducts in lung of mice treated with manufactured gas plant residues (40). The combination of occupational exposure and cigarette smoking may act synergistically and influence dose-response relationships. A synergistic effect of smoking on adduct levels in WBC has also been observed by using an HPLC/fluorescence detection method (13).

The relationship between DNA adducts in WBC and internal organs is still unclear. Some studies on lung cancer patients suggested that adducts in WBC-DNA did not reflect binding of aromatic compounds to lung DNA $(5,41)$. However, in the study of Van Schooten et al. (41), in a group of patients that actually smoked at the day of collecting lung tissue and blood, some correlation was observed between these two parameters $(r=0.5, P=0.19, n=8)$. Recent studies show that adducts in leukocytes or mononucleated white blood cells are correlated with adducts in lung tissue of lung cancer patients (42, 43). Furthermore, Szyfter et al. (44) recently demonstrated a high correlation between the level of aromatic DNA adducts in larynx cells and leukocytes of humans with primary larynx tumors. Therefore, taken together, the available data from rodent and human studies suggest that DNA adducts in lymphocytes might be suitable as surrogates for target tissue. We conclude that DNA adduct formation in both target tissues as well as in lymphocytes are correlated with daily cigarette consumption, and that at high doses saturation of adduct formation may occur.

\section{Acknowledgments}

This work was supported by grants from the European Community, Brussels and the Dutch Prevention Fund (grant no. 28-2397), The Hague, The Netherlands. 


\section{References}

1. Schut, H.A.J and K.T. Shiverick (1992) DNA adducts in humans as dosimeters of exposure to environmental, occupational, or dietary genotoxins. EASEB I., 6, 2942-2951.

2. Cuzick, J., M.N. Routledge, D. Jenkins and R.C. Garner (1990) DNA adducts in different tissues of smokers and nonsmokers. Int. I. Cancer, 45, 673-678.

3 Van Maanen, J.M.S., L.M. Maas, Hageman G., J.C.S. Kleinjans and B. van Agen (1994) DNA adduct and mutation analysis in white blood cells of smokers and non smokers. Environ. Mol. Mutagenesis, 24, 46-50.

4. Phillips, D.H., A. Hewer and P.L. Grover (1986) Aromatic DNA adducts in human bone marrow and peripheral blood leukocytes. Carcinogenesis, 7, 2071-2075.

5. Phillips, D.H., B. Schoket, A. Hewer, E. Bailey, S. Kostic and I. Vincze (1990) Influence of cigarette smoking on the levels of DNA adducts in human bronchial epithelium and white blood cells. Int. J. Cancer, 46, 569-575.

6. Jahnke, G.D., C.L. Thompson, M.P. Walker, J.E. Gallagher, G.W. Lucier and R.P. DiAugustine (1990) Multiple DNA adducts in lymphocytes of smokers and non smokers determined by ${ }^{32} \mathrm{P}$-postlabeling analysis. Carcinogenesis, 11, 205-211.

7. Holz, O., Th. Krause, G. Scherer, U. Schmidt-Preuss, H.W. R-ü-diger (1990) 32pPostlabeling analyses of DNA adducts in monocytes of smokers and passive smokers. Int. Arch. Occup. Environ. Health, 62, 299-303.

8. Savela, K. and K. Hemminki (1991) DNA adducts in lymphocytes and granulocytes of smokers and non smokers detected by ${ }^{32} \mathrm{P}$-postlabeling. Carcinogenesis, 12, 503-508.

9. Santella, R.M., R.A. Grinberg-Funes, T. Lan Young, C. Dickey, V. N. Singh, L. W. Wang and F.P. Perera (1992) Cigarette smoking related polycyclic aromatic hydrocarbonDNA adducts in peripheral mononuclear cells. Carcinogenesis, 13, 2041-2045.

10. Izzotti, A., G.A. Rossi, M. Bagnasco, S. de Flora (1991) Benzo[a]pyrene diolepoxideDNA adducts in alveolar macrophages of smokers. Carcinogenesis, 12, 1281-1285.

11. De Flora, S., A. Izotti, F. D'․ Agostini, G.A. Rossi and R.M. Balansky (1993) Pulmonary alveolar macrophages in molecular epidemiology and chemoprevention of cancer. Environ. Health. Perspect., 99, 249-252.

12. Van Schooten, F.J., F.J. Jongeneelen, M.J.X. Hillebrand, F.E. van Leeuwen, A.J.A. de Looff, A.P.G. Dijkmans, J.G.M. van Rooij, L. den Engelse and E. Kriek (1995) Polycyclic aromatic hydrocarbon-DNA adducts in white blood cell DNA and 1-hydroxypyrene in the urine from aluminum workers: Relation with job category and synergistic effect of smoking. Cancer Epidemiol. Biomarkers_\& Prev., 4, 69-77.

13. Rojas, M., K. Alexandrov, G. Auburtin, A. Wastiaux-Denamur, L. Mayer, B. Mathieu, P. Sebastien and H. Bartsch (1995) Anti-benzo(a)pyrene diolepoxide-DNA adduct levels in peripheral mononuclear cells from coke oven workers and the enhancing effect of smoking. Carcinogenesis, 16, 1373-1376.

14. Bøyum, A. (1976) Isolation of lymphocytes, granulocytes and macrophages. Scand. I. Immunol., 5, 9-15.

15. Reddy, M.V., and K. Randerath (1986) Nuclease-P1 mediated enhancement of sensitivity of ${ }^{32} \mathrm{P}$-postlabeling test for structually diverse DNA-adducts. Carcinogenesis, 7, 1543-1551.

16. Lewtas, J., D. Walsh, L. Dobias, B. Binkova, R. Williams and J.E. Gallagher (1996) Air pollution exposure-DNA adduct dosimetry in humans: evidence for non-linearity at high exposures. Meeting on DNA adducts and mutations in human biomonitoring, June 9-13, Stockholm, Sweden, Abstract.

17. Grzybowska, E., K. Hemminki, J. Szeliga and M. Chorázy (1993) Seasonal variation of aromatic DNA adducts in human lymphocytes and granulocytes. Carcinogenesis, 14, 2523-2526.

18. Ross, J.A., G.B. Nelson, A. Kligerman, G. Erexson, M. Bryant, R.C. Gupta and S. Nesnow (1990) Formation and persistence of novel B[a]P adducts in rat lung and peripheral blood lymphocyte DNA. Cancer Res., 50, 5088-5094. 
19. Ross, J.A., G.B. Nelson, K.H. Wilson, J.R. Rabinowitz, A. Galati, G.D. Stoner, S. Nesnow and M.J. Mass (1995) Adenomas induced by PAH in strain A/J mouse lung correlates with time integrated DNA adduct levels. Cancer Res., 55, 1039-1044.

20. Nesnow, S., J.A. Ross, G.D. Stoner and M.J. Mass (1995) Mechanistic linkage between DNA adducts, mutations in oncogenes and tumorigenesis of carcinogenic environmental polycyclic aromatic hydrocarbons in strain A/J mice. Toxicol., 105, 403413.

21. Nesnow, S., J.A. Ross, G.B. Nelson, K. Holden, G. Erexson, A. Kligerman and R.C. Gupta (1993) Quantitative and temporal relationship between DNA adduct formation. in target and surrogate tissues: implications for biomonitoring. Environ. Health Perspect. suppl., 101, 37-42.

22. Bianchini, F. and C.P. Wild (1994) Comparison of 7-medG formation in white blood cells, liver and target organs in rats treated with methylating carcinogens. Carcinogenesis, 15, 1137-1141.

23. Schut, H.A.J. and C.R. Herzog (1992) Formation of DNA adducts of 2-amino-1-methyl6-phenylimidazo[4,5-b]pyridine (PhIP) in male Fischer 344 rats. Cancer Lett. 67, 117 124.

24. Schut, H.A.J., C.R. Herzog and D.A. Cummings (1994) Accumulation of DNA adducts of 2-amino-3-methylimidazo[4,5-f]quinoline (IQ) in tissues and white blood cells of Fischer-344 rat after multiple oral dosing. Carcinogenesis, 15, 1467-1470.

25. Phillips, D.H., A. Hewer, C.N. Martin, R.C. Garner and M.M. King (1988) Correlation of DNA adduct levels in human lung with cigarette smoking. Nature, 336, 790-792.

26. Van Schooten, F.J., A. Hirvonen, L.M. Maas, B. de Mol, J.C.S. Kleinjans, D.A. Bell and J.D. Durrer (1996) Smoking induced DNA adducts in human right atrial tissue and glutathione-S-transferase (GST) genotypes. Proc. Amer. Assoc. Cancer Res. 37, p 104.

27. Everson, R.B., E. Randerath, R.M. Santella, T.A. Avitts, I.B. Weinstein and K. Randerath (1988) Quantitative associations between DNA damage in human placenta and maternal smoking and birth weight. I. Natl. Cancer Inst., 80, 567-576.

28. Perera, F.P., A. Eastbrook and A. Hewer (1995) Carcinogen-DNA adducts in human breast tissue. Cancer Epidemiol. Biomarkers \& Prev. 4, 233-238.

29. Sandler, D.P., D.L. Shore, J.R. Anderson, F.R. Davey, D. Arthur, R.J. Mayer, R.T. Silver, R.B., Weiss, J.O. Moore, C.A. Schiffer, et al. (1993) Cigarette smoking and risk of acute leukemia: associations with morphology and cytogenetic abnormalities in bone marrow. L. Natl. Cancer Inst., 85, 1994-2003.

30. Bond, J.A., J.L. Mauderly and R.K. Wolff (1990) Concentration and time dependent formation of DNA adducts in lungs of rats exposed to diesel exhaust. Toxicol., 60, 127 135.

31. Van Schooten, F.J., M.J.X. Hillebrand, F.E. van Leeuwen, J.T. Lutgerink, N. van Zandwijk, H.M. Jansen and E. Kriek (1990) Polycyclic aromatic hydrocarbonDNAadducts in lung tissue from lung cancer patients. Carcinogenesis, 11, 1677-1681.

32. Stierum, R.H., M.H.M. van Herwijnen, L.M Maas, G.J. Hageman, J.C.S. Kleinjans (1994) Measurement by 32P-postlabeling of ( \pm ) anti-benzo(a)pyrene diolepoxide-N2deoxyguanosine adduct persistence in unstimulated human peripheral blood lymphocytes. Mutat. Res., 325, 31-37.

33. Celotti, L., P. Ferraro, D. Furlan, N. Zanesi and S. Pavanello (1993) DNA repair in human lymphocytes treated in vitro with $(\cdot \pm \cdot)$-anti- and $(\cdot \pm \cdot)$-syn-benzo(a)pyrene diol epoxide. Mutat. Res., 294, 117-126.

34. Nowak, D., U. Schmidt-Preuss, R. Jörres, F. Liebke and H.W. Rüdiger (1988) Formation of DNA adducts and water soluble metabolites of benzo(a)pyrene in human monocytes is genetically controlled. Int. I. Cancer, 41, 169-173.

35. Nowak, D., A. Meyer, U. Schmidt-Preuss, U. Gatzemeier, H. Magnussen and H.W. Rùdiger (1992) Formation of benzo(a)pyrene-DNA adducts in blood monocytes from lung cancer patients with a familial history of lung cancer. I. Cancer Res. Clin. Oncol., $118,67-71$

36. Hawke, L.J. and G.C. Farrell (1986) Increased binding of benzo(a)pyrene metabolites to lymphocytes from patients with lung cancer. Cancer Lett., 30, 289-297. 
37. Ryberg, D., A. Hewer, D.H. Phillips and A. Haugen (1994) Different susceptibility to smoking-induced DNA damage among male and female lung cancer patients. Cancer Res., 54, 5801-5803.

38. Harris, R.E., E.A. Zang, J.I. Anderson and E.L. Wynder (1993) Race and sex differences in lung cancer risk associated with cigarette smoking. Int. I. Epidemiol., 22, 592-599.

39. Risch, H.A., G.R. Howe, M. Jain, J.D. Burch, E.J. Holoway and A.B. Miller (1993) Are female smokers at higher risk for lung cancer than male smokers? A case-control analysis by histological type. Am. I. Epidemiol., 138, 281-293.

40. Weyand, E.H. and Y. Wu (1995) Covalent binding of polycyclic aromatic hydrocarbons of manufactured gas plant residue to mouse lung and forestomach DNA. Chem. Res. Toxicol., 8, 955-962.

41. Van Schooten, F.J., M.J.X. Hillebrand, F.E. van Leeuwen, N. van Zandwijk, H.M. Jansen, L. den Engelse and E. Kriek (1992) Polycyclic aromatic hydrocarbon DNA adducts in white blood cells from lung cancer patients: no correlation with adduct levels in lung. Carcinogenesis, 13, 987-993.

42. Tang, D., R.M. Santella, A.M. Blackwood, T-L. Young, J. Mayer, A. Jaretzki, S. Grantham, W-Y. Tsai and F.P. Perera (1995) A molecular epidemiological case-control study of lung cancer. Cancer Epidemiol. Biomarkers \& Prev., 4, 341-346.

43. Wiencke, J.K., K.T. Kelsey, A. Varkonyi, K. Semey, J.C. Wain, E. Mark and D.C. Christiani (1995) Correlation of DNA adducts in blood mononuclear cells with tobacco carcinogen-induced damage in human lung. Cancer Res., 55, 49104914.

44. Szyfter,K., K. Hemminki, W. Szyfter, Z. Szmeja, J. Banaszewski and K. Yang (1994) Aromatic DNA adducts in larynx biopsies and leukocytes.Carcinogenesis, 15, 21952199. 


\title{
Chapter 4
}

\section{Exposure route dependent DNA adduct formation by polycyclic aromatic hydrocarbons}

\author{
R.W.L. Godschalk ${ }^{1}$, E.J.C. Moonen ${ }^{1}$, P.A.E.L. Schilderman ${ }^{1}$, \\ W.M.R. Broekmans ${ }^{2}$, J.C.S. Kleinjans ${ }^{1}$, F.J. Van Schooten ${ }^{1}$ \\ ${ }^{1}$ Department of Health Risk Analysis and Toxicology, \\ University of Maastricht, Maastricht, The Netherlands \\ ${ }^{2}$ Current Address: Department of Physiology, TNO-Voeding, \\ Zeist, The Netherlands
}

\section{Submitted to Carcinogenesis}

\begin{abstract}
Understanding the kinetics of formation and removal of aromatic-DNA adducts in target tissues and white blood cells (WBC) would enhance the applicability of WBC as surrogate source of DNA in biomonitoring studies. In the present study, rats were acutely exposed to benzo[a]pyrene (B[a]P, $10 \mathrm{mg} / \mathrm{kg}$ bw) via intratracheal (i.t.), dermal and oral administration. DNA adducts were analyzed in relevant target organs and WBC by nuclease P1 enriched ${ }^{32}$ P-postlabeling at 1, 2, 4, 11 and 21 days after exposure. Additionally, the internal dose was assessed by measurement of urinary excretion of 3-hydroxy-B[a]P (3-OH-B[a]P). In WBC, two adduct spots were observed independently from the exposure route. Total B[a]P-DNA adduct levels in WBC were highest after i.t. and oral administration, whereas. DNA adducts were hardly detectable after dermal exposure. Highest adduct levels in WBC were reached at 2 days after exposure. In lung tissue, DNA adduct levels reached maximal values at 2 days and were highest after respectively i.t., oral and dermal exposure. DNA adduct levels in WBC were significantly lower as compared with lung. In target organs, highest DNA adduct levels were observed in skin after topical application and lowest in stomach after oral administration of B[a]P. Although differences in DNA adduct levels were observed between WBC and target organs after exposure to $\mathrm{B}[\mathrm{a}] \mathrm{P}$ via different exposure routes, overall B[a]P-DNA adduct levels in WBC were significantly related with those in lung. Furthermore, DNA adduct levels in WBC were related with DNA adduct levels in skin after dermal exposure and stomach after oral administration. Two fold higher levels of $3-$ $\mathrm{OH}-\mathrm{B}[\mathrm{a}] \mathrm{P}$ were excreted after i.t. administration of $\mathrm{B}[\mathrm{a}] \mathrm{P}$ as compared with dermal or oral exposure. Urinary 3-OH-B[a]P concentrations were correlated with DNA adduct levels at the site of B[a]P application. Overall, it can be concluded that WBC can be applied as surrogate source of DNA for the site of application of B[a]P. DNA adduct levels in WBC reflect binding to lung DNA, independent of the exposure route.
\end{abstract}




\section{Introduction}

Polycyclic aromatic hydrocarbons (PAH) are widely distributed in the environment in complex mixtures, such as automobile exhaust, cigarette smoke, foods, water and urban air. Human body burden occurs via inhalation, ingestion and dermal absorption, and probably contributes to the overall human cancer risk (1). $\mathrm{PAH}$ are thought to elicit cancer via covalent interactions with DNA, so-called PAHDNA adducts (1), which offer a potential dosimeter for the body load of exposed individuals by these environmental genotoxins. PAH exert their carcinogenic activities at the site of application (1). Also, systemic effects have been observed and the respiratory tract seems to be the most predominant site of B[a]P induced cancers. Unfortunately in humans, most target tissues for genotoxic agents are not readily accessible for monitoring DNA adduct formation and therefore peripheral white blood cells (WBC) most often serve as surrogate source of exposed DNA (2-6). Still, the reliability of WBC as surrogate for target organs needs further research. In particular it is not clear how DNA adduct formation in WBC and relevant target organs may differ dependently on the exposure routes. Inhalatory exposure to PAH in smokers or in occupationally exposed workers does not seem to be the only predominant route $(7,8)$. Other exposure routes, especially via food, appear important for adduct formation in WBC as well. For instance, several studies showed that the consumption of PAH-containing foods enhanced DNA adduct levels in lymphocytes and the excretion of 1-hydroxypyrene in urine (7-9). Additionally, cutaneous application of coal-tar based ointments may result in the formation of measurable amounts of PAH-DNA adducts in total WBC (10) or separated WBC subpopulations (6). Therefore, understanding of the influences of exposure routes on DNA adduct formation in WBC is relevant for exposure monitoring studies. Ideally, nontarget cells should have similar properties as compared with tissues that are targets for tumor induction, with regard to carcinogen metabolism, DNA binding and repair and cell turnover. Detailed knowledge of these parameters for both target tissue and WBC might improve the utility of the latter as surrogate for target tissues.

In the present study, we investigated the relationship between DNA adduct levels in WBC and internal organs in rats acutely exposed to B[al]P weight via three different exposure routes; gavage, dermal administration or intratracheal instillation. Since in animal experiments, carcinogenic PAH become effective predominantly at the site of application (11), B[a]P-DNA adduct levels were studied in lung, stomach and skin by the ${ }^{32} \mathrm{P}$-postlabeling assay. WBC were analyzed by ${ }^{32} \mathrm{P}$-postlabeling as surrogate-tissue. Additionally, excretion of the major B[a]P metabolite 3-hydroxy$\mathrm{B}[\mathrm{a}] \mathrm{P}$ (3-OH-B[a]P) was assessed in 24 hours urine to assess the whole body dose of $\mathrm{B}[\mathrm{a}] \mathrm{P}$. 


\section{Materials \& Methods}

\section{Chemicals}

All solutions used were sterile. B[a]P was purchased from Sigma (St. Louis, MO, USA). Tricaprylin was obtained from ICN Biochemicals Inc. (Ohio, USA). All other chemicals were purchased from Merck (Darmstadt, Germany). Water was purified by means of a milli-Q purification system.

\section{Preparation of B[a]P-solutions for animal treatment}

B[a]P was initially dissolved in acetone at a concentration of $10 \mathrm{mg} / \mathrm{ml}$, which was used for the dermal application of B[a]P as described in the next section. Six ml of this solution was added to an equal volume of trycaprylin and subsequently the acetone was evaporated under nitrogen, resulting in a concentration of $10 \mathrm{mg}$ $\mathrm{B}[\mathrm{a}] \mathrm{P} / \mathrm{ml}$ tricaprylin. This solution was used for oral administration of $\mathrm{B}[\mathrm{a}] \mathrm{P}$ as described in the next section. Identically, $6 \mathrm{ml}$ of $\mathrm{B}[\mathrm{a}] \mathrm{P}$ in acetone was added to $3 \mathrm{ml}$ tricaprylin. Evaporation of the acetone resulted in $20 \mathrm{mg} \mathrm{B}[\mathrm{a}] \mathrm{P} / \mathrm{ml}$, which was used for the intratracheal administration of $\mathrm{B}[\mathrm{a}] \mathrm{P}$. To prevent heterogeneous distributions of $\mathrm{B}[\mathrm{a}] \mathrm{P}$ within these solutions, all were vortexed for 24 hours before use.

\section{Animal treatment}

Fourty five ( $\mathrm{n=45}$ ) male Lewis rats weighing $250-320 \mathrm{~g}$ were acutely exposed to B[a]P (10 $\mathrm{mg} / \mathrm{kg}$ body weight) via oral $(n=15)$, intratracheal $(n=15)$ or dermal administration $(n=15)$. Rats were randomly allocated over the three exposure groups. Nine rats were used as controls ( 3 rats per exposure route; received vehiculum only). Oral exposure: $\mathrm{B}[\mathrm{a}] \mathrm{P}$ was administered through a gavage needle (100 $\mu \mathrm{l} / 100 \mathrm{~g}$ body weight (bw.)). Immediately thereafter, these rats were anesthetized by a subcutaneous injection of ketamin/xylazin (respectively 0.1 and $0.05 \mathrm{ml}$ per $100 \mathrm{gram} \mathrm{bw}$.). Anesthetization was applied to prevent differences in experimental conditions as compared with intratracheal instillation and dermal exposure. Intratracheal exposure: rats were anesthetized by a subcutaneous injection of ketamin/xylazin, and subsequently a plastic tube $(0: 2 \mathrm{~mm})$ was placed into the trachea. B[a]P solutions were injected into the lung through this plastic tube $(50 \mu \mathrm{l} /$ $100 \mathrm{~g} \mathrm{bw}$.) and artificial respiration was applied briefly. Dermal exposure: rats were anesthetized by a subcutaneous injection of ketamin/xylazin. Approximately $4 \mathrm{~cm}^{2}$ $(2 \times 2 \mathrm{~cm})$ of the skin was shaved (back-side, between shoulders) and B[a]P-solutions were pipetted on this area $(100 \mu \mathrm{l} / 100 \mathrm{~g} \mathrm{bw}$.).

The animals were housed individually in metabolic cages for collection of urine, in a room maintained at $25^{\circ} \mathrm{C}, 50 \%$ humidity and a $12 \mathrm{hr}$. light/dark cycle. Standard rodent lab chow (diet no. RSM-A, Hope Farms, Woerden, The Netherlands) and water were provided ad libitum. Each morning, 24 hours-urine was collected individually. The samples were weighed and stored at $-20^{\circ} \mathrm{C}$ until analysis. To examine the time-course of adduct formation, the rats were killed. 1, 2, 4, 11 and 21 days after treatment (three rats per time-point). Lung, stomach and skin were removed, washed with PBS and quickly frozen at $-20^{\circ} \mathrm{C}$ until DNA isolation. Blood was collected by aortic puncture and WBC were isolated by lysis of erythrocytes 
with 3 volumes of lysis buffer $\left(155 \mathrm{mM} \mathrm{NH}_{4} \mathrm{Cl}, 10 \mathrm{mM} \mathrm{KHCO}, 10 \mathrm{mM}\right.$ EDTA, pH $7.4)$ at $4^{\circ} \mathrm{C}$ and subsequently collected by centrifugation at $4^{\circ} \mathrm{C}$ for 10 minutes $(800 \mathrm{~g})$. Separation of WBC subpopulations was not performed, because WBC of Lewis-rats consist for more than. $95 \%$ of lymphocytes.

\section{DNA isolation}

Approximately 1 gram of tissue was washed with $0.25 \mathrm{M}$ sucrose/ $0.1 \mathrm{M}$ Tris- $\mathrm{HCl}$ ( $\mathrm{pH} 7.4$ ), cut into small pieces and subsequently homogenized with a potter (1000 $\mathrm{rpm}$ ) in $1 \% \mathrm{SDS} / 1 \mathrm{mM}$ EDTA. The solutions were incubated overnight at $37^{\circ} \mathrm{C}$ with $0.5 \mathrm{mg}$ Proteinase $\mathrm{K}$. WBC were lysed with $2.5 \mathrm{ml}$ SDS/NEP $(75 \mathrm{mM} \mathrm{NaCl}, 25 \mathrm{mM}$ EDTA, $50 \mathrm{mg} / \mathrm{ml}$ Proteinase $\mathrm{K}, 1 \%$ SDS) and incubated for 4 hours at $37^{\circ} \mathrm{C}$. DNA was extracted with phenol: chloroform: isoamylalcohol $(25: 24: 1, v / v / v)$ and chloroform: isoamylalcohol $(24: 1, \mathrm{v} / \mathrm{v})$ respectively. The DNA was precipitated with two volumes of cold ethanol after addition of $1 / 30$ volume $3 \mathrm{M}$ sodiumacetate, $\mathrm{pH}$ 5.3 and washed with $70 \%$ ethanol. Subsequently, DNA was dissolved in $5 \mathrm{mM}$ Tris/ $1 \mathrm{mM}$ EDTA, pH 7.4. RNase T1 $(50 \mathrm{U} / \mathrm{ml})$ and RNase A $(100 \mu \mathrm{g} / \mathrm{ml})$ were added, followed by $30 \mathrm{~min}$. of incubation at $37^{\circ} \mathrm{C}$. The solutions were extracted with chloroform: isoamylalcohol $(24: 1, \mathrm{v} / \mathrm{v})$ and DNA was precipitated from the aqueous phase with cold ethanol, washed with $70 \%$ ethanol and dissolved in $2 \mathrm{mM}$ Tris, pH 7,4 . Concentration and purity were determined spectrophotometrically by absorbances at 230,260 and $280 \mathrm{~nm}$. In all cases, $A_{260} / A_{280}$ were $\sim 1.8$ and $A_{230} / A_{260}$ were $\sim 0.43$. The final volume was adjusted to achieve a DNA-concentration of 2 $\mathrm{mg} / \mathrm{ml}$.

\section{${ }^{32}$-postlabeling}

The ${ }^{32} \mathrm{P}$-postlabeling assay was performed as described by Reddy and Randerath (12) with some modifications. Briefly, DNA (ca. $10 \mu \mathrm{g}$ ) was digested using micrococcal endonuclease (0.4 Units) and spleen phosphodiesterase ( $2.8 \mu \mathrm{g})$ for 3 hours at $37^{\circ} \mathrm{C}$. Subsequently, half of the digest was treated with nuclease P1 $(6.3 \mu \mathrm{g})$ for 40 minutes at $37^{\circ} \mathrm{C}$. The modified nucleotides were labeled with [ $\left.\gamma^{32} \mathrm{P}\right]-\mathrm{ATP}(50$ $\mu \mathrm{Ci} /$ sample) by incubation with T4-polynucleotide kinase (5.0 Units) for 30 minutes at $37^{\circ} \mathrm{C}$. NP1-efficiency and ATP-excess were checked with an aliquot of the NP1 treated fraction by one dimensional chromatography on poly(ethylenimine)(PEI)cellulose sheets (solvent: $0.12 \mathrm{M} \mathrm{NaH}_{2} \mathrm{PO}_{4}$ pH 6.8 on Merck-sheets, Germany). Radiolabeled adduct nucleotide biphosphates were separated by chromatography on PEI-cellulose sheets (Machery Nagel, Germany). The following solvent systems were used: D1, $1 \mathrm{M} \mathrm{NaH}_{2} \mathrm{PO}_{4} \mathrm{pH} 6.5 ; \mathrm{D} 2,8.5 \mathrm{M}$ urea, $5.3 \mathrm{M}$ lithiumformate $\mathrm{pH} 3.5$; D3, 1.2 M lithiumchloride, 0.5 M Tris, 8.5 urea $\mathrm{pH} 8.0$; $\mathrm{D} 4,1.7 \mathrm{M} \mathrm{NaH}_{2} \mathrm{PO}_{4} \mathrm{pH} 6.0$. The remaining half of the digest was used to determine the final amount of DNA in the assay; the normal nucleotides were labeled with $\left[\gamma^{32} \mathrm{P}\right]-\mathrm{ATP}$ ( $15 \mu \mathrm{Ci} /$ sample) by incubation with T4-polynucleotide kinase (2.5 Units) for 30 minutes at $37^{\circ} \mathrm{C}$. Nucleotides were separated by one dimensional chromatography on PEI-cellulose sheets (solvent: $0.12 \mathrm{M} \mathrm{NaH} \mathrm{PO}_{4} \mathrm{pH}$ 6.8 on Merck-sheets, Germany). A dAp standard $(27.5$ pmole $/ \mu \mathrm{l})$ was labeled in each experiment for quantitation purposes. In each experiment, 3 standards of [3H]BPDE modified DNA with known 
modification levels ( 1 per $10^{7}, 10^{8}, 10^{9}$ nucleotides) were run parallelly for quantitation purposes. Quantitation was performed by using phosphor imaging technology (Molecular Dynamics ${ }^{\mathrm{TM}}$, Sunnyvale) with which detection limits of 1 adduct per $10^{9}$ nucleotides can be obtained. Interassay variation was $<25 \%$.

\section{3-OH-B[a]P in rat urine}

Detection of 3-OH-B[a]P in 24-hours urine was performed as described by Jongeneelen et al. (13). The method consisted of enzymatic hydrolysis with Bglucuronidase and arylsulphatase, solid phase extraction on a Sep-pak C-18 cartridge and elution with methanol. Reversed phase HPLC (Kratos solvent delivery system; Column: Hypersil 5 ODS) and fluorescence detection (Perkin-Elmer LS-30) were applied, using excitation and emission wavelengths of $253 \mathrm{~nm}$ and $432 \mathrm{~nm}$. Peak area was integrated for quantification. The detection limit was $200 \mathrm{ng} 3-\mathrm{OH}$ B[a]P per liter urine. Day-to-day variation and intra-assay variation were respectively $14 \%$ and $6 \%$.

\section{Statistics}

Results are presented as mean \pm standard deviation. Student's t-tests were applied to assess statistical differences between DNA adduct levels in various tissues and linear regression was applied to examine the quantitative relationship between DNA adducts in WBC and tissues. $\mathrm{P}<0.05$ is considered significant.

\section{Results}

\section{Qualitative results of adduct analysis in B[a]P treated rats}

The first two days after treatment of rats with an acute dose of $\mathrm{B}[\mathrm{a}] \mathrm{P}$, the eating and drinking behavior was influenced as determined by reweighing the supplied food and water. Relative weights of lung and stomach (organ weight/ total body weight) was constant during the experiment.

In WBC-DNA of exposed rats, two DNA adduct spots were observed independently from the exposure route, of which the predominant one comigrated with the BPDE-DNA adduct standard. The second adduct spot migrated slower as compared with the BPDE-DNA adduct standard in both chromatographic directions. In lung, stomach and skin, two similar adduct spots were observed, but in B[a]Ptreated skin an additional third DNA adduct spot was found (Figure 1). Thus, overall adduct formation in WBC seemed to be qualitatively in agreement with DNA adducts found in organs.

\section{Quantitative results of adduct analysis in rat organs and WBC}

Total DNA adduct levels were calculated by adding the levels of individual DNA adduct spots. In WBC, maximal adduct levels after respectively i.t. $(4.3 \pm 0.5$ addlucts per $10^{8}$ nucleotides), oral $(3.6 \pm 1.8)$ or dermal $(0.3 \pm 0.2)$ application of $\mathrm{B}[\mathrm{a}] \mathrm{P}$ were found at ca. two days after exposure (Figure 2). The estimated half-life of DNA adducts in WBC was 2 weeks, calculated on basis of a semi-logarithmic plot. In lung tissue of exposed rats identical adduct kinetics were observed; at day 2 after 
exposure via i.t., oral and dermal administration of B[a]P, DNA adduct levels reached $20.5 \pm 5.1$ adducts per $10^{8}$ nucleotides, $6.9 \pm 2.3$ and $0.5 \pm 0.2$, respectively.

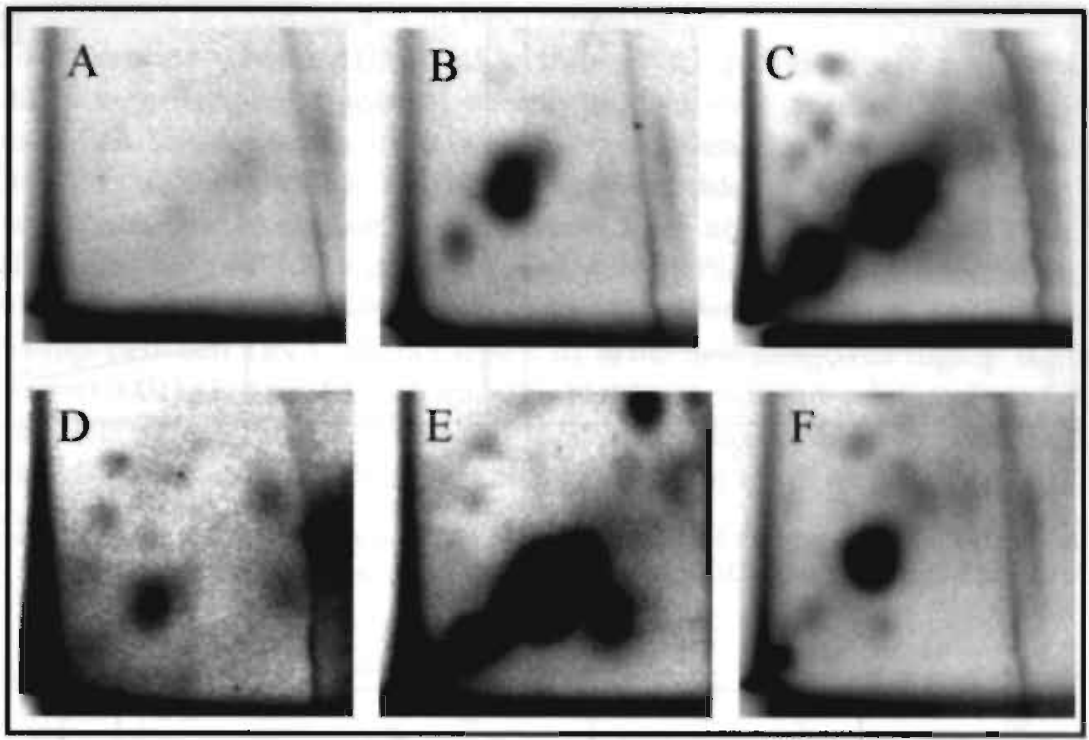

Figure 1. Adduct profiles obtained by ${ }^{32}$ p-postlabeling. Origins are located at the lower left corner and were excised before analysis. A; WBC DNA of a non-treated rat. B; WBC DNA of a rat exposed to $B[a] P$ by gavage ( $t=2$ days after exposure). $C$; Lung DNA of a rat i.t. exposed to $B[a] P$ ( $t=2$ days). D; Stomach DNA of a rat orally exposed to $\mathrm{B}[\mathrm{a}] \mathrm{P}(\mathrm{t}=1$ day). E; Skin DNA of a rat dermally exposed to $\mathrm{B}[\mathrm{a}] \mathrm{P}$ ( $\mathrm{t}=2$ days). F; BPDE-DNA adduct standard (modification level: 1 adduct per $10^{7} \mathrm{nt}$ )

The removal of DNA adducts in lung-tissue over a period of 21 days appeared to be inversely related with the maximal DNA adduct level. Highest DNA adduct levels in lung were observed after i.t. exposure, but adduct levels decreased relatively fast (at day 21 , only $34 \%$ of the maximal adduct level was detected). Oral administration of $\mathrm{B}[\mathrm{a}] \mathrm{P}$ resulted in maximal adduct levels in lung that were ca. 3 fold lower as compared with i.t. exposure, but adduct persistence was higher (at day 21, $74 \%$ of the maximal adduct level was still detectable). Highest persistence of DNA adducts in lung was observed after dermal application of B[a]P (no decrease of adducts from day 2 to day 21), whereas maximal DNA adduct levels were only $0.5 \pm 0.2$ adducts per $10^{8}$ nucleotides (Figure 2).

Since carcinogenic PAH become effective predominantly at the site of application, also DNA adduct formation in skin after dermal application and stomach after oral administration of $\mathrm{B}[\mathrm{a}] \mathrm{P}$ was studied. High adduct levels were found in skin-DNA at two days after exposure by dermal application of B[a]P' (70.3 \pm 14.0 adducts per $10^{5}$ nucleotides). Total DNA adduct levels in stomach after oral administration of B[a]P were surprisingly low. In stomach, maximal DNA. adduct levels were observed at day 1 after exposure (1.6 \pm 0.5 adducts per $10^{8}$ nucleotides), and thereafter adduct levels gradually decreased (Figure 3). Adduct 
persistence appeared to be identical for both tissues, with calculated half-lives of 16 days.
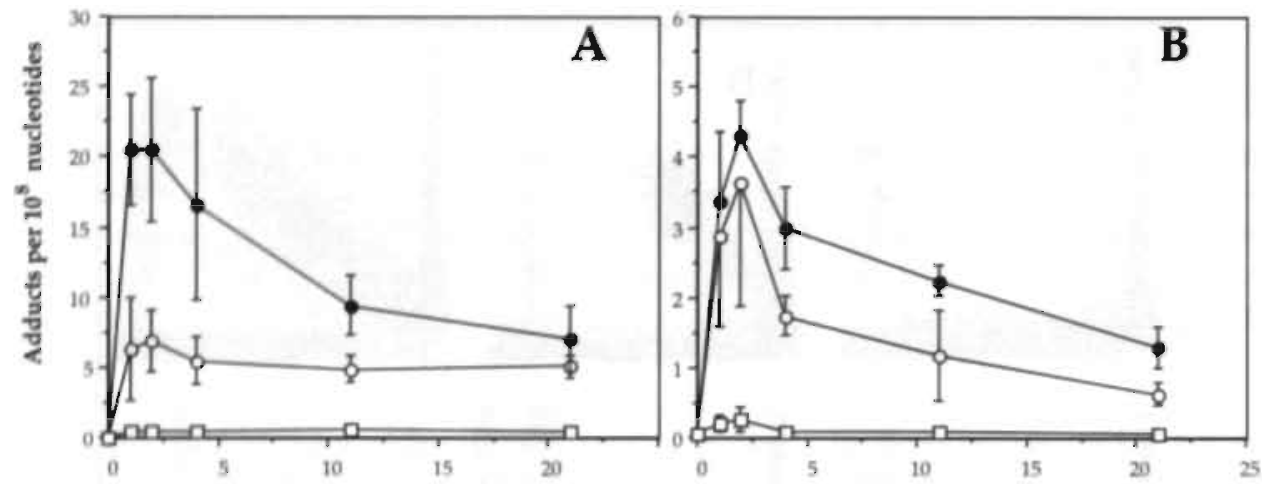

Days after exposure

Figure 2. Kinetics of DNA adduct levels in lung tissue (Panel A) and WBC (panel B) after acute exposure to B[a]P via i.t. (๑), oral (O) and dermal (J) application of B[a]P (10 mg/ kg bw.).

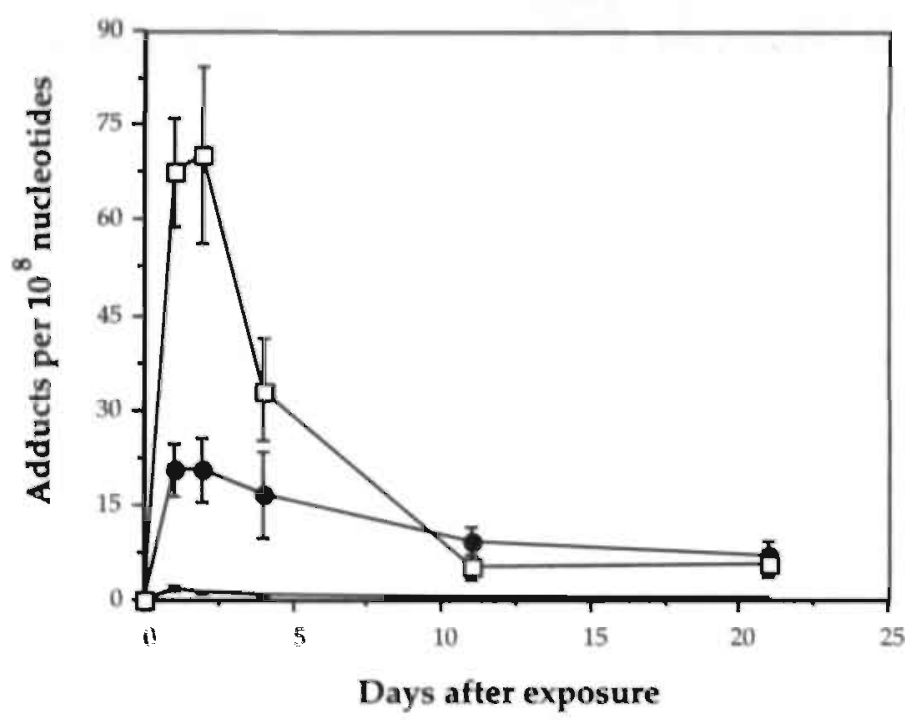

Figure 3. Kinetics of DNA adducts in rat lung after i.t. exposure (-), in stomach after oral administration $(O)$ and in skin after dermal application ( $(J)$ of $B[a] P(10 \mathrm{mg} / \mathrm{kg} \mathrm{bw}$.).

DNA adduct levels in WBC after i.t., oral and dermal exposure were significantly lower as compared with DNA adducts in lung (respectively ca. 5, 3 and 4 fold, $\mathrm{P}<0.001$ ). If DNA adducts in WBC were compared with adduct levels at the site of application, significantly higher adduct levels were found in lung ( $\mathrm{P}=0.0001)$ and skin $(\mathrm{P}=0.0004)$ after respectively i.t. and dermal application. On the other hand, 
exposure of rats to $\mathrm{B}[\mathrm{a}] \mathrm{P}$ by gavage resulted in ca. 2.5 fold higher adduct levels in WBC as compared with the site of entry of $\mathrm{B}[\mathrm{a}] \mathrm{P}$; the stomach $(\mathrm{P}=0.0012)$.

\section{Regression analysis of DNA adducts in WBC versus tissues}

To determine whether DNA adducts in WBC quantitatively represent DNA adducts in target organs, linear regression models were applied. The relationship between DNA adduct levels in WBC (as independent variable $\mathrm{x}$ ) and total DNA adduct levels in lung tissue (as dependent variable $y$ ) was influenced by the exposure route. The slopes of the regression lines after respectively i.t., oral and dermal application of B[a]P were respectively 5.0 (95\% confidence Interval: 3.7 - 6.4 , $\mathrm{P}<0.001), 1.4(0.7-2.0, \mathrm{P}<0.001)$ and $0.7(-0.3-1.7, \mathrm{P}=0.18)$ (Figure $4 \mathrm{~A})$. The overall relationship between DNA adduct levels in WBC and lung was highly significant ( $r=0.83, P=0.0001$ ) (Figure 4B). Identically, highly significant relationships between DNA adducts in WBC and stomach after oral application of $\mathrm{B}[\mathrm{a}] \mathrm{P}(\mathrm{r}=0.80, \mathrm{P}=0.0001)$ and between WBC and skin after dermal application of $\mathrm{B}[\mathrm{a}] \mathrm{P}(\mathrm{r}=0.61, \mathrm{P}=0.0077)$ were observed.

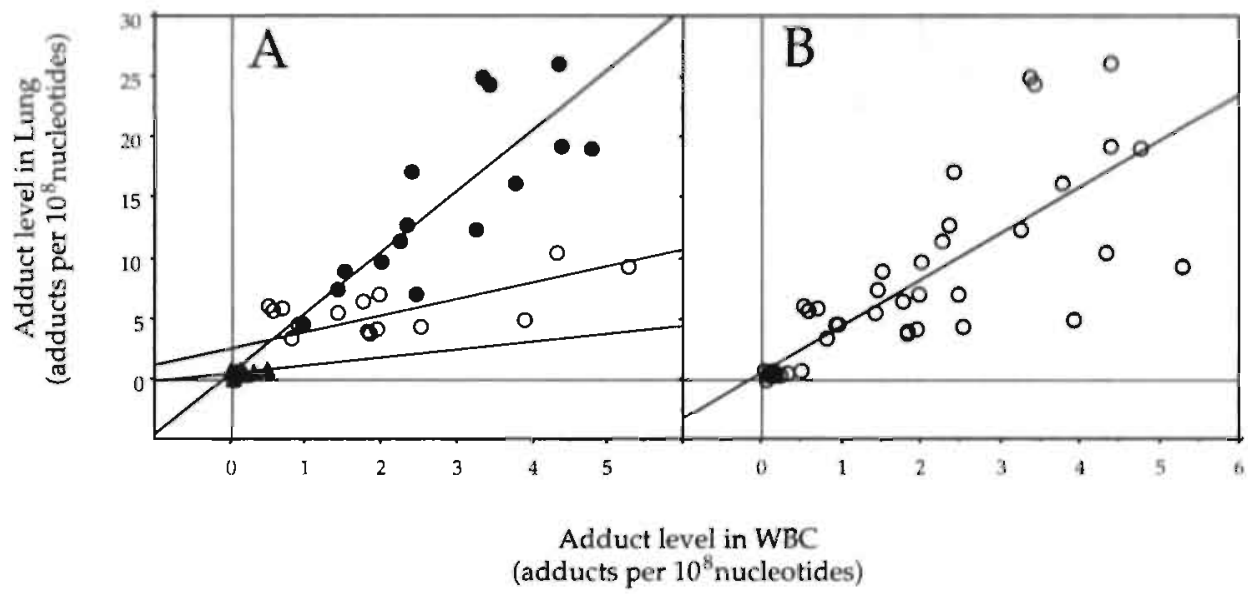

Figure 4. Relationship between total DNA adduct levels in WBC (x) and lung tissue (y) after 3 different exposure routes. Panel $A_{;}(\bullet)$ intratracheally, $(\bigcirc)$ orally, and $(\boldsymbol{\Delta})$ dermally exposed rats. Panel B; Overall relationship $(r=0.83, p=0.0001)$.

\section{3-OH-B[a]P excretion in 24-hours urine}

To assess the internal dose, we measured a major $\mathrm{B}[\mathrm{a}] \mathrm{P}$ metabolite, 3-OH-B[a]P, in 24-hour urine. Highest excretion levels were found after i.t. exposure, which reached a 'peak' value of $11.5 \mu \mathrm{g} / 24$ hours at day 2 after exposure. Highest levels of urinary 3-OH-B[a]P after dermal and oral exposure were respectively $4.8 \mu \mathrm{g} / 24$ hours (at day 2) and $4.5 \mu \mathrm{g} / 24$ hours (at day 1). Thereafter, the excretion quickly 
sensitive exposure-marker or biomarker for the biologically effective dose in target organs.

Most carcinogenic PAH become effective predominantly at the site of application (11). As expected, DNA adduct levels in exposed skin were high. However, DNA adduct levels in stomach were surprisingly low after oral exposure to a relatively high dose of $\mathrm{B}[\mathrm{a}] \mathrm{P}$. This is in line with the local carcinogenic effect of $\mathrm{B}[\mathrm{a}] \mathrm{P}$, since considerable higher doses are required after oral exposure as compared with dermal application of $\mathrm{B}[\mathrm{a}] \mathrm{P}$ to reach a similar incidence of tumors (11). Under normal circumstances, the mucous layer of the gastrointestinal tract hampers the absorption of the lipophilic B[a]P. Nonetheless, DNA adduct levels in remote tissues and the urinary excretion of 3-OH-B[a]P indicated that considerable amounts of $\mathrm{B}[\mathrm{a}] \mathrm{P}$ were absorbed after oral exposure. Dermal exposure resulted in relatively high DNA adduct levels at the site of application, but the systemic effect (i.e., adduct formation in WBC and lung) appeared to be much lower. On the other hand, $3-\mathrm{OH}-$ $\mathrm{B}[\mathrm{a}] \mathrm{P}$ excretion in dermally exposed animals was not lower as compared with oral exposed rodents. These observations suggest that the metabolic conversion of $\mathrm{B}[\mathrm{a}] \mathrm{P}$ to (non)reactive derivatives in skin itself is of importance. However, dermal exposure to coal-tar ointments (i.e., a complex chemical mixture that contains PAH) may result in higher systemic effect as compared with dermal treatment with single PA.H (data not shown). Intratracheal instillation of B[a]P resulted in considerable systemic and local effects regarding DNA adduct formation. Furthermore, analysis of 24-hours urine showed that ca. $1 \%$ of the administered dose was excreted as 3$\mathrm{OH}-\mathrm{B}[\mathrm{a}] \mathrm{P}$ after i.t. exposure, whereas after respectively oral and topical administration of $\mathrm{B}[\mathrm{a}] \mathrm{P}$ the cumulative excretion added up to only 0.4 and $0.6 \%$, respectively. Also, Jacob et al. (25) found higher levels of monohydroxylated metabolites of $\mathrm{B}[\mathrm{a}] \mathrm{P}$ in urine after intratracheal instillation as compared with oral exposure. Furthermore, Jongeneelen et al. (26) reported that the cumulative excretion of $3-\mathrm{OH}-\mathrm{B}[\mathrm{a}] \mathrm{P}$ in rat urine was only 0.22 to $0.35 \%$ of the orally administered dose after three consecutive high doses of $\mathrm{B}[\mathrm{a}] \mathrm{P}$.

The urinary excretion of $3-\mathrm{OH}-\mathrm{B}[\mathrm{a}] \mathrm{P}$ correlated significantly with adduct formation at the site of application of $\mathrm{B}[\mathrm{a}] \mathrm{P}$. In a recent study, we found 3-OH-B[a]P concentrations in urine of individuals topically treated with ointments that contained B[a]P also correlated with BPDE-DNA adduct levels in skin-DNA (6). Most studies in PAH-exposed humans used 1-hydroxypyrene in urine as dosimeter for the internal dose of PAH $(5,8,27,28)$, because it can be detected more easily as it is excreted in high levels. Whereas, the mother compound (pyrene) or its derivatives do not react with DNA. This might explain the conflicting results in the limited number of studies that examined the association between urinary 1-hydroxypyrene and DNA adducts in humans $(5,8,27,28)$. Furthermore, since the changes in urinary concentrations of $\mathrm{PAH}$-metabolites after exposure to $\mathrm{PAH}$ are relatively fast, the sampling timing and/or period is of major importance. In the present study, levels of 3-OH-B[a]P were back to baseline levels within 11 days after the exposure, thus measurements of urinary 3-OH-B[a]P seem to represent recent exposures only.

Overall, it can be concluded that aromatic-DNA adduct levels in WBC can be applied as surrogate source of DNA at the site of exposure and reflect binding of 
B[a]P derivatives to lung DNA, independently from the exposure route. Furthermore, the urinary excretion of $3-\mathrm{OH}-\mathrm{B}[\mathrm{a}] \mathrm{P}$ coincided with DNA adduct formation, but measurements of urinary PAH-metabolites represent recent exposures only.

\section{References}

1. Hall, M., Grover, P.L.(1990) Polycyclic aromatic hydrocarbons: metabolism, activation, tumor-initiation. In Cooper, C.S., Grover, P.L. (eds) Chemical carcinogenesis and mutagenesis, Raven Press, New York, vol. 1, pp. 327-372.

2. Holz, O., Krause, Th., Scherer, G., Schmidt-Preuss, U., Rüdiger, H.W. (1990) 32p. postlabeling analyses of DNA adducts in monocytes, of smokers and passive smokers. Int. Arch. Occup. Environ. Health, 62, 299-303.

3. Santella, R.M., Grinberg-Funes, R.A., Lan Young, T', Dickey, C., Nath Singh, V., Wenwang, L., Perera, F.P.(1992) Cigarette smoking related polycyclic aromatic hydrocarbon-DNA adducts in peripheral mononuclear cells. Carcinogenesis, 13, 20412045.

4. Van Schooten, F.J., Godschalk, R.W.L., Breedijk, A., Maas, L.M., Kriek, E., Sakai, H., Wigbout, G., Baas, P., Van 't Veer, L., Van Zandwijk, N. (1997) 32P-postlabeling of aromatic DNA adducts in white blood cells and alveolar macrophages of smokers: saturation at high exposures. Mut. Res, 378, 65-75.

5. Kuljukka, T., Savela, K., Vaaranrinta, R., Mutanen, P., Veidebaum, T., Sorsa, M., Peltonen, K. (1998) Low response in white blood cell DNA adducts among workers in highly polluted cokery environment. I. Occup. Environ. Med., 40, 529-537.

6. Godschalk, R.W.L., Ostertag, J.U., Moonen, E.J.C., Neumann, H.A.M., Kleinjans, J.C.S., Van Schooten, F.J. (1998) Aromatic DNA adducts in human white blood cells and skin after dermal application of coal tar. Cancer Epidemiol. Biomarkers \& Prev, 7, 767-773.

7. Rothman, N., Correa-Villasenor, A., Ford, D.P., Poirier, M.C., Haas, R.A., Hansen, J.A., O'Toole, T., Strickland, P.T. (1993) Contribution of occupation and diet to white blood cell PAH DNA adducts in wildland firefighters. Cancer Epidemiol. Biomarkers \& Prev. 2, 341-347.

8. Van Maanen, J.M.S., Moonen, E.J.C., Maas, L.M., Kleinjans, J.C.S., Van Schooten, F.J. (1994) Formation of aromatic DNA adducts inwhite blood cells in relation to urinary excretion of 1-hydroxy-pyrene during consumption of grilled meat. Carcinogrenesis, 15 , 2263-2268.

9. Rothman, N., Poirier, M.C., Haas, R.A., Correa-Villasenor, A., Ford, P., Hansen, J.A., O'Toole, T., Strickland, P.T.(1993) Association of PAH DNA adducts in peripheral white blood cells with dietary exposure to PAH. Environ. Health Perspect. 99, 265-26\%.

10. Paleologo, M., Van Schooten, F.J., Pavanello, S., Kriek, E., Zordan, M., Clonfero, E., Brezze, C., Levis A.G. (1992) Detection of benzo(a)pyrene-diol-epoxide-DNA adducts in white blood cells of psoriatic patients treated with coal-tar. Mut. Res., 281, 11-16.

11. Steinhoff, D. (1983) Oral application. In: Grimmer, G. (ed.) Environmental carcinogens: Polycyclic aromatic hydrocarbons. CRC Press, Inc. Boca Raton, Florida USA, 203-219

12. Reddy, M.V., Randerath,K. (1986) Nuclease P1 mediated enhancement of sensitivity of 32P-postlabeling test for structually diverse DNA-adducts. Carcinogenesis. 7, 15431551.

13. Jongeneelen, F.J., Bos, R.P., Anzion, R.B.M., Theeuws, J.L.G., Henderson. P.T.(1986) Biological monitoring of polycyclic aromatic hydrocarbons in urine. Scand. J.Work Environ. Health, 12, 137-143.

14. Schulte, P.A., Perera, F.P. (1993) Validation. In Schulte, P.A., Perera, F.P.(Eds) Molecular Epidemiology: principles and practices. Academic Press, New York. 
15. Phillips, D.H., Schoket, B., Hewer, A., Bailey, E., Kostic, S., Vincze, I. (1990) Influence of cigarette smoking on the levels of DNA adducts in human bronchial epithelium and white blood cells. Int. I. Cancer, 46, 569-575.

16. Van Schooten, F.J., Hillebrand, M.J.X., van Leeuwen, F.E., van Zandwijk, N., Jansen, H.M., den Engelse, L., Kriek, E. (1992) Polycyclic aromatic hydrocarbon DNA adducts in white blood cells from lung cancer patients: no correlation with adduct levels in lung. Carcinogenesis, 13, 987-993.

17. Wiencke, J.K., Kelsey, K.T., Varkonyi, A., Semey, K., Wain, J.C., Mark, E., Christiani, D.C. (1995) Correlation of DNA adducts in blood mononuclear cells with tobacco carcinogen-induced damage in human lung. Cancer Res. 55, 4910- 4914.

18. Szyfter, K., Hemminki, K., Szyfter, W., Szmeja, Z., Banaszewski, J,, Yang, K. (1994) Aromatic DNA adducts in larynx biopsies and Leukocytes. Carcinogenesis, 15, 21952199 ,

19. Schut, H.A.J., Herzog, C.R.(1992) Formation of DNA adducts of 2-amino-1-methyl-6phenylimidazo[4,5-b]pyridine (PhIP) in male Fischer 344 rats. Cancer Lett., 67, 117-124.

20. Schut, H.A.J., Herzog, C.R., Cummings, D.A.(1994) Accumulation of DNA adducts of 2-amino-3-methylimidazo[4,5-f]quinoline (IQ) in tissues and white blood cells of Fischer-344 rat after multiple oral dosing. Carcinogenesis, 15, 1467-1470.

21. Bianchini, F., Wild, C.P.(1994) Comparison of 7-medG formation in white blood cells, liver and target organs in rats treated with methylating carcinogens. Carcinogenesis, $15,1137-1141$.

22. Ross, J.A., Nelson, G.B., Kligerman, A., Erexson, G., Bryant, M., Gupta, R.C., Nesnow, S. (1990) Formation and persistence of novel B[a]P adducts in rat lung and peripheral blood lymphocyte DNA. Cancer Res, 50, 5088-5094.

23. Nesnow, S., Ross, J.A., Nelson, G.B., Holden, K., Erexson, G., Kligerman, A, Gupta, R.C. (1993) Quantitative and temporal relationship between DNA adduct formation in target and surrogate tissues: implications for biomonitoring. Environ. Health Perspec. $101,37-42$.

24. Qu, S.X., Stacey, N.H. (1996) Formation and persistence of DNA adducts in different target tissues of rats after multiple administrations of benzo[a]pyrene. Carcinogenesis, $17,53-59$.

25. Jacob, J., Brune, H., Grimmer, G., Heinrich, U., Mohtashamipur, E., Norpoth, K., Pott, F., Wenzel-Hartung, R. (1990) Urinary and faecal excretion of metabolites after various modes of administration of polycyclic aromatic hydrocarbons to rats. In: Seemayer, N.H., Hadinagy, W. (eds) Environmental Hygiene II, Springer Verlag, Berlin, 87-90.

26. Jongeneelen, F.J., Leijdekkers, C.M., Bos, R.B., Theeuws, J.L.G., Henderson, P.T. (1985) Excretion of 3-OH-Benzo[a]pyrene and mutagenicity in rat urine after exposure to benzo[a]pyrene. I. Appl. Tox., 5, 277-282.

27. Santella, K.M., Hemminki, K., Tang, D.L., Paik, M., Ottman, R., Young, T.L., Savela, K., Vodickova, L., Dickey, C., Whyatt, R., Perera, F.P. (1993) Polycyclic aromatic hydrocarbon-DNA adducts in white blood cells and urinary 1-hydroxypyrene in foundry workers. Cancer Epidemiol. Biomarkers \& Prev., 2, 59-62.

28. Van Schooten, F.J., Jongeneelen F.J., Hillebrand, M.J.X., Van Leeuwen, F.E., de Looff, A.J.A., Dijkmans, A.P.G., Van Rooij, J.G.M., Den Engelse, L., Kriek, E. (1995) Polycyclic aromatic hydirocarbon-DNA adducts in white blood cell DNA and 1-hydroxypyrene in the urine from aluminium workers: relation with job-category and synergistic effects of smoking. Cancer Epidemiol. Biomarkers \& Prev. 4, 69-77. 


\title{
Chapter 5
}

\section{DNA adduct removal in mononuclear blood cells of smokers after smoking cessation}

\author{
R.W.L. Godschalk ${ }^{1}$, D.E.M. Feldker ${ }^{2}$, P.J.A. Borm", \\ E.F.M. Wouters ${ }^{4}$, F.J. Van Schooten ${ }^{1}$ \\ 1 Department of Health Risk Analysis and Toxicology, \\ University of Maastricht, Maastricht, The Netherlands \\ 2 Current Address: Department of Medical Pharmacology, \\ University of Leiden, Leiden, The Netherlands \\ 3 Current Address: Department of Toxicology of Dust and Fibers \\ Medizinisches Institut für Umwelt Hygiene, Düsseldorf, Germany \\ 4. Department of Pulmonology, \\ Academic Hospital Maastricht, Maastricht, The Netherlands
}

\begin{abstract}
Carcinogen-DNA adduct measurements have been used to assess human exposure to polycyclic aromatic hydrocarbons (PAH). However, tissues in which PAH may induce tumors are not accessible for routine monitoring of DNA adducts. Therefore, mononuclear blood cells (i.e., monocytes plus lymphocytes, MNC) often serve as surrogate source of DNA. To evaluate the applicability of DNA adducts in MNC as a measure of current and/or past exposure to aromatic compounds, aromatic-DNA adducts were assessed by nuclease P1 enriched ${ }^{32} \mathrm{P}$-postlabeling in MNC of 24 smoking individuals before and after a non-smoking period of 22 weeks. A group of 10 never-smokers was used to assess background levels of aromatic-DNA adducts. Before smoking cessation, DNA adducts levels in MNC $\left(0.76 \pm 0.41\right.$ adducts $/ 10^{8}$ nucleotides) were positively correlated with cigarette-consumption ( $r=0.51, p=0.01$ ) and inversely related with body mass index (weight/height ${ }^{2}$ ) adjusted for age and gender $(r=-0.48, p=0.02)$. After 22 weeks of non-smoking, DNA adduct levels in $\mathrm{MNC}$ declined to $0.44 \pm 0.23$ adducts / $10^{8}$ nucleotides $(\mathrm{P}=0.002)$, which was not significantly different as compared with never-smokers $(0.39 \pm 0.23)$. A half-life of 12 weeks was calculated for aromatic-DNA adduct levels in MNC on the basis of a semi-logarithmic plot and subtraction of the average background level obtained from never-smokers. When a linear model for the elimination of aromatic-DNA adducts in MNC was applied, it was calculated that DNA adducts would reach background levels after 25 weeks of smoking cessation. The persistence of DNA adducts in MNC was inversely related with the aromatic-DNA adduct level before smoking cessation $(r=-0.55, p=0.033)$. It can be concluded that DNA adduct levels in MNC reflect exposure to tobacco associated aromatic compounds and when exposure to tobacco smoke is stopped, adduct levels in MNC decrease accordingly.
\end{abstract}




\section{Introduction}

Polycyclic aromatic hydrocarbons (PAH) are ubiquitous environmental pollutants particularly present in tobacco smoke, which are thought to elicit lung cancer by covalent interactions with DNA, so-called DNA adducts (1). Theoretically, the level of DNA adducts indicates the capacity of an individual to cope with carcinogen exposure. Therefore, the quantitation of PAH-DNA adducts probably is a good indicator for the biologically effective dose and could be of use in risk assessment. However, lung tissue is rarely accessible in a non-clinical setting and white blood cells (WBC) have been used as surrogate source of DNA. Although several studies showed controversial results regarding the effect of smoking on DNA adduct levels in WBC (2-5), it has been suggested that the mononuclear cell fraction (i.e., monocytes plus lymphocytes, MNC) can be used to assess exposure to tobacco derived aromatic compounds (6, 7). Aromatic-DNA adduct levels in MNC correlated with the amount of cigarettes smoked per day (7) and moreover, might correlate with aromatic-DNA adduct levels in lung tissue (6). Nonetheless, measurements of DNA adducts in MNC require further validation before they can be used in exposure or risk assessment. For example, it should be known whether DNA adduct measurements have the ability to integrate PAH exposure over a relatively long (a few months up to years) period of time and also whether these measurements can detect previous exposures after a long period of non-exposure. The half-life of PAH. DNA adducts in lymphocytes was estimated to be between 9 to 13 weeks after cessation of smoking using a competitive ELISA (8). On the other hand, much lower elimination rates have been reported for DNA adducts in lung tissue $(9,10)$. Further evaluation of elimination curves of aromatic-DNA adducts is necessary.

The uptake and elimination rates of PAH might be influenced by body composition, since PAH are lipid soluble and tend to accumulate in adipose tissue. Indeed, in one recent study, a positive correlation was observed between the body mass index (weight/height ${ }^{2}, \mathrm{BMI}$ ) and aromatic-DNA adducts in pancreatic tumor tissues (11). On the contrary, it was consistently found that smokers with a low BMI have an increased risk for developing lung malignancies as compared with smokers of average weight (12-16). This inverse relationship is considered by some investigators to be due to incomplete adjustment for the effect of cigarette smoking (15). In this respect, DNA adduct measurements give the opportunity to further investigate the link between BMI and lung cancer risk in smokers. Furthermore, after smoking cessation, accumulated PAH might be released into the peripheral blood and would prolong the apparent half-life of DNA adducts in MNC.

Thus, in the present study, the relationship between DNA adduct levels and cigarette consumption is further investigated by nuclease $\mathrm{P} 1$ enriched ${ }^{32} \mathrm{P}$ postlabeling in MNC obtained from 24 individuals who stopped smoking for 22 weeks. Moreover, the impact of BMI on DNA adduct levels and adduct elimination in MNC was studied. 


\section{Materials \& Methods}

\section{Study-populations}

Hundred healthy smoking subjects, willing to stop smoking, were recruited at the Asthma Center Hornerheide in Horn (The Netherlands) by means of media advertisement. The weight $(\mathrm{kg})$ and height $(\mathrm{m})$ of these individuals was obtained and the BMI was calculated $\left(\mathrm{kg} / \mathrm{m}^{2}\right)$. After informed consent, $10 \mathrm{ml}$ blood was collected at the initial visit, i.e., the day before quitting smoking. The subjects applied nicotine-patches daily to increase the success-rate of smoking cessation. After 22 weeks, 32 individuals succeeded in continuing complete abstinence from smoking and blood-samples of 24 individuals (age: $44 \pm 8$ years, 14 male and 10 female) could be used for adduct analysis. This group of volunteers had smoked on average $24 \pm 9$ cigarettes per day over a period of $27 \pm 8$ years before smoking cessation. A control group of 10 healthy never-smokers without occupational exposure to PAH (age: $38 \pm 12$ years, 3 male and 7 female) was selected to assess background levels. Overall characteristics are presented in Table I.

Table I. Characteristics of the group of individuals who stopped smoking for 22 weeks (study group I) and the group of never-smokers (study group II).

\section{Study Group I}

Number of subjects $(n)$

Gender (Male/Female)

Age (years \pm SD)

Cigarettes / day

Smoking Years

Body Mass Index $\left(\mathrm{kg} / \mathrm{m}^{2}\right)$

Male / Female
24

$14 / 10$

$44 \pm 8$

$24 \pm 91$

$27 \pm 8$

$25.5 \pm 2.7$

$26.3 \pm 2.7 / 24.1 \pm 2.2$

Study Group II

10.

$3 / 7$

$38 \pm 12$

0

0

Unknown

$M N C$ and DNA isolation

MNC were separated from polymorphonuclear cells. (granulocytes) by gradient centrifugation on lymphoprep according to Bøyum (17). The MNC fractions were washed twice with PBS and stored at $-20^{\circ} \mathrm{C}$ until DNA isolation. MNC were lysed with $2.5 \mathrm{ml} \mathrm{SDS/NEP} \mathrm{(75} \mathrm{mM} \mathrm{NaCl}, 25 \mathrm{mM}$ EDTA, $50 \mu \mathrm{g} / \mathrm{ml}$ Proteinase $\mathrm{K}, 1 \%$ SDS) and incubated for 4 hours at $37^{\circ} \mathrm{C}$. DNA was extracted with phenol: chloroform: isoamylalcohol $(25: 24: 1, \mathrm{v} / \mathrm{v} / \mathrm{v})$ and chloroform: isoamylalcohol $(24: 1, \mathrm{v} / \mathrm{v})$ respectively. The DNA was precipitated with two volumes of cold ethanol after addition of $1 / 30$ volume $3 \mathrm{M}$ sodiumacetate, pH 5.3 and washed with $70 \%$ ethanol. Subsequently, DNA was dissolved in $2 \mathrm{mM}$ Tris, $\mathrm{pH} 7,4$. Concentration and purity were determined spectrophotometrically by absorbance at 230, 260 and $280 \mathrm{~nm}$ and the final volume was adjusted to achieve a DNA-concentration of $2 \mathrm{mg} / \mathrm{ml}$. 


\section{${ }^{32}$ P-postlabeling}

The ${ }^{32} \mathrm{P}$-postlabeling assay was performed as described by Reddy and Randerath (18) with some modifications. All samples were encoded. DNA $(10 \mu \mathrm{g})$ was digested using micrococcal endonuclease ( 0.4 Units) and spleen phosphodiesterase ( $2.8 \mu \mathrm{g})$ for 3 hours at $37^{\circ} \mathrm{C}$. Subsequently, half of the digest was treated with nuclease P1 (6.3 $\mu \mathrm{g})$ for 40 minutes at $37^{\circ} \mathrm{C}$. The modified nucleotides were labeled with $\left[\gamma^{32} \mathrm{P}\right]-\mathrm{ATP}$ $(50 \mu \mathrm{Ci} /$ sample) by incubation with $\mathrm{T} 4$-polynucleotide kinase (5.0 Units) for 30 minutes at $37^{\circ} \mathrm{C}$. NP1-efficiency and ATP-excess were checked with an aliquot of the NP1 treated fraction by one-dimensional chromatography on poly(ethyleneimine)(PEI)-cellulose sheets from Merck, Germany (solvent: $0.12 \mathrm{M}$ $\mathrm{NaH}_{2} \mathrm{PO}_{4} \mathrm{pH}$ 6.8). Radiolabeled adduct nucleotide biphosphates; were separated by chromatography on PEI-cellulose sheets from Machery Nagel (Germany). The following solvent systems were used: $\mathrm{D} 1,1 \mathrm{M} \mathrm{NaH}_{2} \mathrm{PO}_{4} \mathrm{pH} 6.5 ; \mathrm{D} 2,8.5 \mathrm{M}$ urea, 5.3 $\mathrm{M}$ lithium formate $\mathrm{pH} 3.5$; D3, $1.2 \mathrm{M}$ lithium chloride, $0.5 \mathrm{M}$ Tris, $8.5 \mathrm{M}$ urea pH 8.0; D4, $1.7 \mathrm{M} \mathrm{NaH}_{2} \mathrm{PO}_{4} \mathrm{pH}$ 6.0. In each experiment, 3 standards of [ $\left.{ }^{3} \mathrm{H}\right] \mathrm{BPDE}$ modified DNA with known modification levels ( 1 per $10^{7}, 10^{8}, 10^{9}$ nucleotides) were run paraljelly for quantification purposes. Quantification was performed by using phosphor-imaging technology (Molecular Dynamics ${ }^{\mathrm{TM}}$, Sunnyvale, CA, USA) with a detection limit of $<1$ adduct per $10^{9}$ nucleotides for individual spots. The detection limit of a diagonal radioactive zone (DRZ) was around 5 adducts per $10^{9}$ nucleotides. Samples with no detectable DNA adduct levels were considered to have adduct levels of 0.25 adducts per $10^{8}$ nucleotides (half of the detection limit for DRZ). The remaining half of the digest was used to determine the final amount of DNA in the assay; the normal nucleotides, were diluted and labeled with $\left[\gamma^{32} \mathrm{P}\right]-\mathrm{ATP}(15 \mu \mathrm{Ci}$ / sample) by incubation with T4-polynucleotide kinase ( $2.5 \mathrm{Units}$ ) and a 10-fold molar excess of unlabeled ATP for 30 minutes at $37^{\circ} \mathrm{C}$. A dAp standard (27.5 pmole/ $\left./ \mathrm{ll}\right)$ was labeled in each experiment for quantification purposes. Nucleotides were separated by one-dimensional chromatography on PEI-cellulose sheets from Merck (solvent: $0.12 \mathrm{M} \mathrm{NaH}_{2} \mathrm{PO}_{4} \mathrm{pH}$ 6.8); samples with apparent protein or RNA contamination were discarded.

\section{Statistical analysis}

Results are presented as mean \pm standard deviation. A paired t-test was used to assess differences in DNA adduct levels at $t=0$ (before smoking cessation) and $t=22$ weeks and an unpaired $t$-test was applied to assess differences between (ex)smokers and never-smokers. Linear regression models were applied to determine the relationships between smoking behavior, BMI and DNA adduct levels in MNC. The half-life of aromatic-DNA adducts in MNC was estimated using linear regression on log-transformed adduct levels and exact time, adjusting for background levels by subtracting the average DNA adduct level of non-smoking controls (considered as background). $\mathrm{P}<0.05$ was considered significant. 


\section{Results}

Adduct levels in MNC at baseline measurements

DNA adduct profiles obtained by ${ }^{32} \mathrm{P}$-postlabeling and subsequent thin layer chromatography were identical for all smoking subjects; diagonal radioactive zones (DRZ's) were observed, which are typical for exposure to cigarette smoke (Figure 1). In never-smokers, only three individuals showed faint DRZ's and no adducts were detected in the other subjects.

Adduct levels in smokers $\left(0.76 \pm 0.41\right.$ adducts per $10^{8}$ nucleotides) were significantly higher as compared with never-smokers $(0.39 \pm 0.23, P=0.03)$. Moreover, aromatic-DNA adduct levels in MNC of smoking individuals were significantly related with the self-reported amount of cigarettes smoked per day $(r=0.51, p=0.01$, Figure 2), and were inversely related with the BMI adjusted for age and $\operatorname{sex}(r=-0.48$, $\mathrm{P}=0.02$, Figure 3 ). This relationship was borderline significant after DNA adduct levels were corrected for the amount of cigarettes smoked per day ( $r=0.40, P=0.055)$. If both parameters were used as independent variables in a multiple regression analysis, a significant overall relationship was observed $(r=0.63, p=0.007)$.

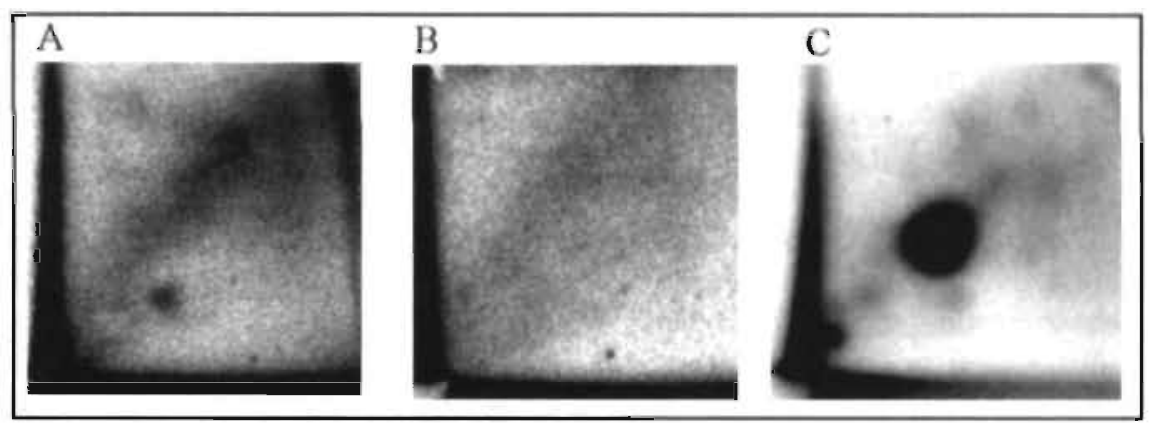

Figure 1. Aromatic-DNA adduct profiles observed in MNC of a smoking individual before (A) and after (B) smoking cessation for 22 weeks. Panel $C$ represents a BPDE-DNA adduct standard with a modification level of 1 adduct per $10^{7}$ nucleotides.

Adduct levels after 22 weeks of smoking cessation

Adduct profiles were not changed by smoking cessation for a period of 22 weeks. Similar DRZ's were observed, but with lower intensities (Figure 1). Adduct levels had significantly decreased to $0.44 \pm 0.23$ adducts per $10^{8}$ nucleotides $(\mathrm{P}=0.002$ as compared with levels before smoking cessation) and were no longer significantly different as compared with those found in never-smokers ( $\mathrm{P}=0.42)$. Still, DNA adducts could be observed in MNC of 15 out of 24 individuals (63\%), whereas in never-smokers this was 3 out of $10(30 \%)$. The apparent half-life of aromatic-DNA adducts in MNC using a semi-logarithmic plot was 24 s weeks. However, a more reliable estimate of 12 weeks was obtained after correction by subtracting background levels. Using a linear model for adduct elimination, it was calculated 
that aromatic-DNA adduct levels in MNC would reach the average background levels at 25 weeks after smoking cessation.

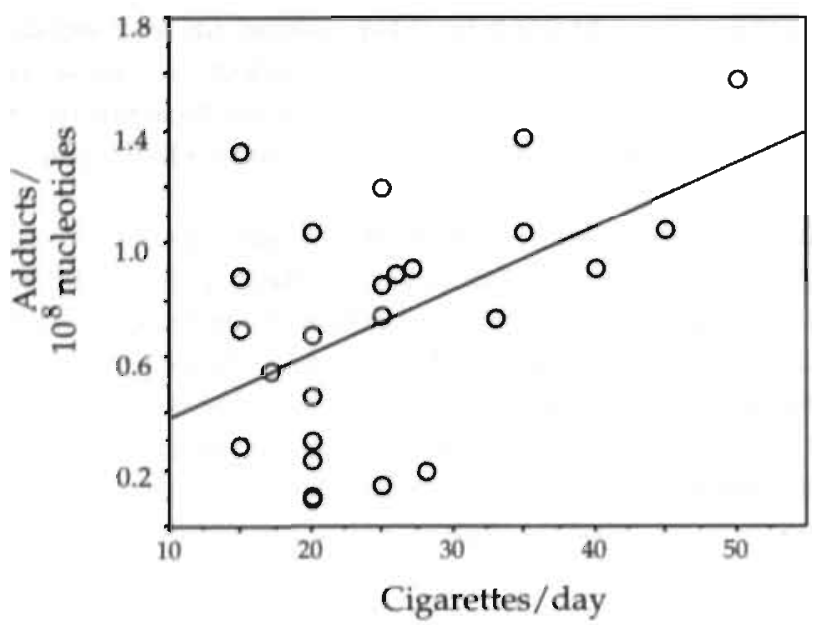

Figure 2. Relationship between daily cigarette consumption and aromatic DNA adduct levels in MNC of current smokers $(r=0.51, P=0.01, n=24)$.

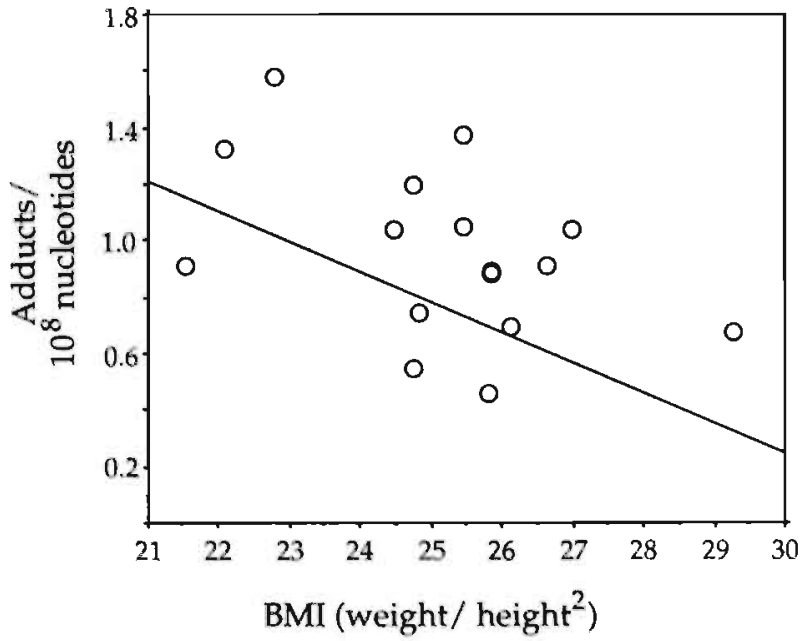

Figure 3. Relationship between the body mass index and aromatic-DNA adduct levels in MNC of current smokers $(r=-0.48, p=0.02, n=24)$.

The relative decrease in DNA adduct levels was significantly and inversely correlated with the initial DNA adduct level $(\mathrm{r}=-0.55, \mathrm{P}=0.03)$; individuals with high adduct levels at $t=0$ showed a stronger decline in DNA adduct levels as compared 
with individuals with low initial DNA adduct levels. In this analysis, to obtain a reliable estimate for adduct removal only individuals with detectable DNA adduct levels before and after smoking cessation were used $(n=15$, Figure 4). Although no impact of BMI on adduct elimination was observed, the BMI was found to significantly influence the initial DNA adduct level, and therefore, an effect of BMI on decreasing DNA adduct levels can not completely be excluded.

\section{Discussion}

In the present study, aromatic-DNA adducts in MNC seemed to reflect exposure to tobacco smoke and adduct levels significantly decreased after exposure to tobacco smoke was stopped. Aromatic-DNA adducts in MNC were significantly related with the current amount of cigarettes smoked per day. After exposure to tobacco smoke was stopped, DNA adduct levels in MNC decreased accordingly with an estimated half-life of ca. 12 weeks. Additionally, an effect of the BMI was observed on the formation of aromatic-DNA adducts in MNC. Lower adducts levels were observed in individuals with a high BMI.

Previous studies already indicated that the use of MNC would probably reflect tobacco smoke exposure more reliably as compared with total WBC $(6,7)$. Polymorphonuclear cells, quantitatively the most predominant WBC-type in blood, contain only low levels of DNA adducts $(5,7)$ and the life-span of this cell-type is short (hours-days). Therefore, they would reflect recent exposures to PAH only (19). In the MNC fraction, the life-span of monocytes is also short (several days). Recent studies showed no clear differences between monocytes and lymphocytes during continuous exposure $(7,19)$. On the other hand, if exposure was stopped, adduct levels in the monocyte fractions were found to decline to baseline-levels within one week (19). Therefore, the isolation of lymphocytes might be even more promising to assess past exposures to $\mathrm{PAH}$, since this cell-type has a longer life-span. Furthermore, a large fraction of the lymphocytes seems to migrate to non-Jymphoid organs, like the lung, are exposed to inhaled carcinogens at that site and slowly redistribute into the peripheral blood $(20,21)$. Thus, in the present study, part of the observed decline in DNA adduct levels in MNC is probably due to the short half-life of monocytes.

Removal of aromatic-DNA adducts in WBC $(22,23)$ and lung $(9)$ seems to occur in two phases; an initial fast reduction of DNA adduct levels, followed by a period in which adduct elimination is much slower. In the present study, the calculated halflife of tobacco related DNA adducts in MNC obtained by ${ }^{32} \mathrm{P}-$ postlabeling is in line with previous results obtained by ELISA. (8). Identically, Pavanello et al. (24) and Paleologo et al. (25) showed a significant reduction of PAH-DNA adducts over a period of 2-5 months after the end of topical treatment with coal-tar ointments, which contained high levels of PAH. An inverse correlation was observed between adduct elimination and the initial DNA adduct level, which indicates that adducts are more efficiently removed by DNA repair or cell turn-over at higher levels of DNA damage. Persistence of DNA adducts in lung tissue is reported to be higher as 
compared with DNA adducts in WBC (8-10). Nonetheless, Wiencke et al. (6) found a correlation between DNA adduct levels in MNC and lung, even if short- and longterm ex-smokers were included in the analysis. This indicates that DNA adduct removal from MNC may coincide with DNA adduct elimination in lung after smoking cessation.

A correlation between BMI and DNA adduct formation was previously reported for pancreatic tumor tissues by Wang et al. (11). In that study, a high BMI coincided with higher adduct levels. However, in the present study the opposite was observed. Similarly, Loft et al. (26) found lower levels of oxidative DNA damage in individuals with high BMI's, especially in those who smoked cigarettes. Possible explanations for these observations is that individuals with a high BMI have relatively lower metabolic rates as compared with lean individuals (27) and PAH can be immobilized in adipose tissue.

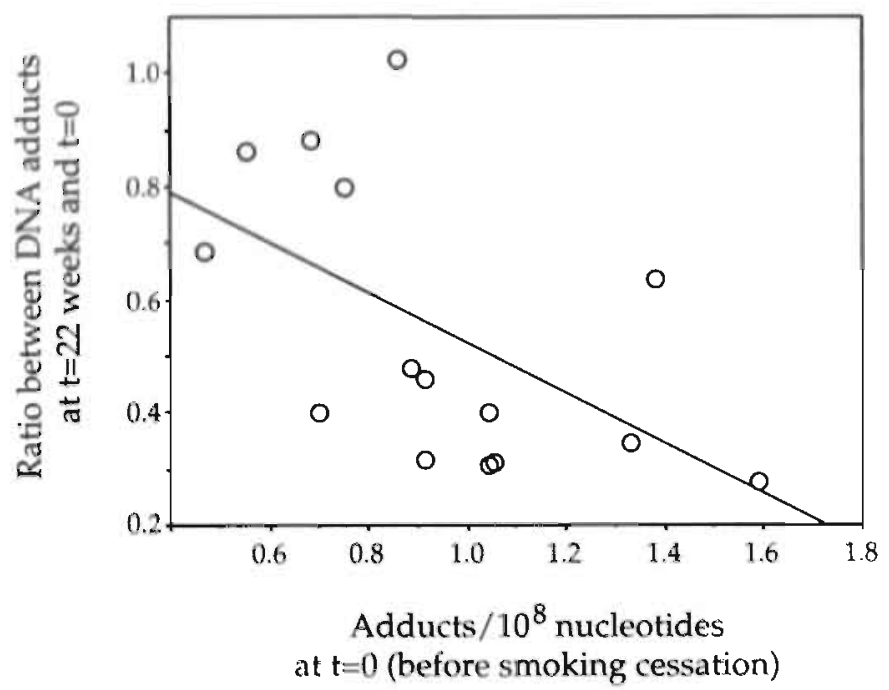

Figure 4. Relative persistence of DNA adducts in MNC (adduct level at $t=22$ divided by adduct levels at $t=0)$ correlated with the initial DNA adduct level in MNC before smoking cessation ( $r=-0.55$, $\mathrm{p}=0.033, \mathrm{n}=15$ ).

The results of the present study further support the idea that DNA adducts in MNC can be used to assess lung cancer risk, because the levels of aromatic-DNA adducts seemed to correlate with several risk factors for lung cancer. For instance, DNA adduct levels in MNC (7) and lung cancer risk (28) both correlate with the amount of cigarettes smoked per day and both decrease after smoking cessation (8, 29). Moreover, DNA adducts were inversely correlated with the BMI. Identically, a low BMI has consistently been identified as a risk-factor for the development of lung malignancies (12-16). 
After smoking cessation, accumulated PAH mobilized from adipose tissue might serve as an additional source of $\mathrm{PAH}$ exposure. Thus, the elimination rate of aromatic DNA adducts in MNC may be influenced by the body composition. Although we observed no direct impact of BMI on adduct reduction, the BMI was found to significantly influence the DNA adduct level before smoking cessation. Since adduct removal depended on the initial adduct level, an effect of BMI cannot be excluded. Furthermore, it can not be distinguished whether the adducts that are detected after a period of nonexposure are formed due to background exposures, were already present in longer-lived lymphocytes, and/or are formed due to the release of $\mathrm{PAH}$ from adipose tissue.

In conclusion, DNA adduct levels in MNC reflect exposure to tobacco associated aromatic compounds and change accordingly if exposure is altered. The observation that adduct levels in MNC are significantly influenced by the BMI needs further confirmation.

\section{References}

1. Hall, M., Grover, P.L. (1990) polycyclic aromatic hydrocarbons: metabolism, activation and tumor initiation. In: Cooper, C.S., Grover, P.L. (eds) Chemical carcinogenesis and mutagenesis. Vol. 1. Raven Press, new York, pp. 327-372.

2. Van Maanen, J.M.S., Maas, L.M., Hageman, G., Kleinjans, J.C.S., Van Agen, B. (1994) DNA adduct and mutation analysis. Environ. Health Perspec, 24: 46-50.

3. Savela, K., Hemminki, K. (1991) DNA adducts in lymphocytes and granulocytes of smokers and nonsmokers detected by the ${ }^{32}$ P-postlabeling assay. Carcinogenesis, 12: 503-508.

4. Van Schooten, F.J., Hillebrand, M.J.X., Leeuwen, F.E., Van Zandwijk, N., Jansen, H.M., Engelse, L.D., Kriek, E. (1992) Polycyclic aromatic hydrocarbon DNA in white blood cells from lung cancer patients: no correlation with adducts in lung. Carcinogenesis, 13: 987-993.

5. Phillips, D.H., Hewer, A., Grover, P.L., (1986) Aromatic DNA adducts in human bone marrow and peripheral blood leukocytes. Carcinogenesis, 7: 2071-2075.

6. Wiencke, J.K., Kelsey, K.T., Varkonyi, A., Semey, K., Wain, J.C., Mark, E., Christiani, D.C. (1995) Correlation of DNA adducts in blood mononuclear cells with tobacco carcinogen-induced damage in human lung. Cancer Res., 55: 4910- 4914.

7. Godschalk, R.W.L., Maas, L.M., Van Zandwijk, N., Van 't Veer, L.J, Breedijk, A., Borm, P.J.A., Verhaert, J., Kleinjans, J.C.S., Van Schooten, F.J., (1998) Differences in aromaticDNA adduct levels between alveolar macrophages and subpopulations of white blood cells from smokers. Carcinogenesis, 19: 819-825.

8. Mooney, L.V.A., Santella, R.M., Covey, L., Jeffrey, A.M., Bigbee, W., Randall, M.C., Cooper, T.B., Ottman, R., Tsai, W.Y., Wazneh, L., Glassman, A.H., Young, T.L., Perera, F.P. (1995) Decline of DNA damage and other biomarkers in peripheral blood following smoking cessation. Cancer Epidemiol. Biomarkers \& Prev. 4: 627-634.

9. Schoket, B., Phillips, D.H., Kostic, S., Vincze, I. (1998) Smoking associated bulky DNA. adducts in bronchial tissue related to CYPIA1 MspI and GSTM1 genotypes in lung, patients. Carcinogenesis, 19: 841-846.

10. Dunn, B.P., Vedal, S., San, R.H.C., Kwan, W.F., Nelems, B., Enarson, D.A., Stich, H. (1991) DNA adducts in bronchial biopsies. Int. J. Cancer, 48: 485-492.

11. Wang, M., Abbruzzese, J.L., Friess, H., Hittelman, W.N., Evans, D.B., Abbruzzese, M.C., Chiao, P., Li, D. (1998) DNA adducts in human pancreatic tissues and their potential role in carcinogenesis. Cancer Res., 58: 38-41. 
12. Goodman, M.T., Wilkens, L.R. (1993) relation of bodysize and risk of lung cancer. Nutr. Cancer, 20: 179-186.

13. Kabat, G.C., Wynder, E.L. (1992) Body Mass Index and lung cancer risk. Am. I. Epidemiol, 135: 769-774.

14. Tulinius, H., Sigfusson, N., Sigvaldason, H., Bjarnadottir, K., Tryggvadottir, L. (1997) Risk factors for malignant diseases: a cohort study on a population of 22,946 Icelanders. Cancer Epidemiol. Biomarkers \& Prev., 6: 863-873.

15. Drinkard, C.R., Sellers, T.A., Potter, J.D., Zheng, W., Bostick, R.M., Nelson, C.L., Folsom, A.R. (1995) Association of body mass index and body fat distribution with risk of lung cancer in older women. Am. J. Epidemiol., 142: 600-607.

16. Knekt, P., Heliovaraa, M., Rissanen, A., Aromaa, A., Seppanen, R., Teppo, L., Pukkala, E. (1991) Leanness and lung cancer risk. Int. I. Cancer, 49:208-213.

17. Boyum, A. (1976) Isolation of lymphocytes, granulocytes and macrophages. Scand. I. Immunol., 5: 9-15.

18. Reddy, M.V., Randerath, K. (1986) Nuclease P1 mediated enhancement of sensitivity of ${ }^{32}$ P-postlabeling test for structurally divers DNA adducts. Carcinogenesis, 7: 1543-1561.

19. Godschalk, R.W.L., Ostertag, J.U., Moonen, E.J.C., Neumann, H.A.M., Kleinjans, J.C.S., Van Schooten, F.J. (1998) Aromatic DNA adducts in human white blood cells and skin after dermal application of coal tar. Cancer Epidemiol. Biomarkers \& Prev., 7, 767-773.

20. Pabst, R., Binns, R.M. (1989) heterogeneity of lymphocyte homing physiology: several mechanisms operate in the control of migration to lymphoid and non-lymphoid organs in vivo. Immunol. Rev., 108: 83-109.

21. Pabst, R., Binns, R.M., Rothkotter, H.G., Westermann, J. (1993) Quantitative analysis of lymphocyte fluxes in vivo. Current Top. Microbiol. Immunol, 12:503-508.

22. Stierum, R.H., Van Herwijnen, M.H.M., Maas, L.M., Hageman, G.J., Kleinjans, J.C.S. (1994) Measurement by 32P-postlabeling of ( \pm )benzo[a]pyrene-diol-epoxide- $\mathrm{N}^{2}$ deoxyguanosine adduct persistence in unstimulated human peripheral blood lymphocytes. Mut. Res., 325: 31-37.

23. Celotti, L., Ferraro, P., Furlan, D., Zanesi, N., Pavanello, S. (1993) DNA repair in human lymphocytes treated in vitro with ( \pm )anti- and $( \pm$ )syn-benzo[a]pyrene diol-epoxide. Mut. Res., 294: 117-126.

24. Pavanello, S., Levis, A.G. (1994) Human peripheral blood lymphocytes as a cell model to evaluate the genotoxic effect of coal tar treatment. Environ. Health Perspect., 102 Suppl. 9, 95-99

25. Paleologo, M., van Schooten, F.J., Pavanello, S., Kriek, E., Zordan, M., Clonfero, E., Brezze, C., Levis, A.G. (1992) Detection of benzo[a]pyrene-diol-epoxide-DNA adducts in white blood cells of psoriatic patients treated with coal tar. Mutat. Res., 281, 11-16.

26. Loft, S., Vistisen, K., Ewertz, M., Tjonneland, A., Overvad, K., Poulsen, H.E. (1992) Oxidative DNA damage estimated by 8-hydroxy-deoxyguanosine excretion in humans: influence of smoking, gender and body mass index. Carcinogenesis, 13: 2241-2247.

27. Shah, M., Miller, D.S., Geissler, C. A. (1988) Lower metabolic rate of post obese versus lean women: thermogenesis, basal metabolic rate and genetics. Eur. I. Clin. Nutr., 42: 741-752.

28. Fielding, J.E. (1985) Smoking; Health effects and control (first of two parts). New Engl. I. Med., 313:491-498. Second of two parts, 313: 555-561.

29. Sobue, T., Yamaguchi, N., Suzuki, T., Fujimoto, I., Matsuda, M., Doi, O., Mori, T., Foruse, K., Fukuoka, M., Yasumitsi, T., Kuwahara, O., Ichitani, M., Taki, T., Kuwabara, M., Nakahara, K., Endo, S., Sawamura, K., Kurata, M., Hattori, S. (1993) Lung cancer incidence rate for male exsmokers according to age at cessation of smoking. Ipn. I. Cancer. Res., 84: 601-607. 


\title{
Chapter 6
}

\section{Genetic polymorphisms in GSTM1 and NAT2 in relation to aromatic- DNA adducts in smokers}

\author{
R.W.L. Godschalk, L.M. Maas, E. Van Agen, F.J. Van Schooten \\ Department of Health Risk Analysis and Toxicology, \\ University of Maastricht, Maastricht, The Netherlands
}

\begin{abstract}
Carcinogen-DNA adduct levels may be modulated by host polymorphisms in genes that encode enzymes involved in the metabolism of environmental pollutants, such as polycyclic aromatic compounds. In this study, aromatic-DNA adduct levels were examined by nuclease $\mathrm{Pl}$ enriched ${ }^{32} \mathrm{P}$-postlabeling in mononuclear blood cells (MNC) and cells obtained by broncho-alveolar lavages (BAL) trom smoking volunteers, and related to genetic polymorphisms of glutathione S-transferase $\mathrm{Mi}$ (GSTM1) and $\mathrm{N}$-acetyl transferase 2 (NAT2). DNA adduct levels in MNC were significantly related with the amount of cigarettes smoked per day $(r=0.26, P=0.035)$ and were significantly higher in GSTM1(-/-) individuals ( $1.35 \pm 0.55$ adducts per $10^{8}$ nucleotides) as compared with GSTM1(+) subjects $(1.03 \pm 0.57, \mathrm{P}=0.021)$. On the other hand, DNA adduct levels in BAL-cells of these individuals were not significantly related with the GSTM1 polymorphism. The NAT2 polymorphism was found to be associated with DNA adduct levels in MNC (respectively $1.32 \pm 0.64$ and $1.04 \pm 0.45$ for slow and fast acetylators, $\mathrm{P}=0.047)$ and. BAL-cells after correction for age and gender (respectively $6.91 \pm 1.78$ and $5.37 \pm 1.62, \mathrm{P}=0.074$ ). When the GSTM1 and NAT2 genotypes were combined, highest DNA adduct levels were observed in MNC of slow acetylators that lacked the GSTM1-gene (1.45 \pm 0.62$)$ and lowest DNA adduct levels in those with the fast acetylator/GSTM1(+) genotypes $(0.86 \pm 0.42, \mathrm{P}=0.010)$. Overall, the observed relationships were still present after adjustment for the amount of cigarettes smoked per day, but with 'borderline' significances only. 'These results indicate that polymorphisms in the GSTM1 and NAT2 genes may influence the formation of aromatic-DNA adducts in smoking individuals.
\end{abstract}

\section{Introduction}

Many cancers may be attributable to chemical carcinogens such as polycyclic aromatic hydrocarbons (PAH), which are present in tobacco smoke (1). PAH are lipid soluble and tend to accumulate in organisms, unless they are oxidatively metabolized to water soluble derivatives to facilitate excretion in urine or feces. However, some PAH derivatives become electrophilic and may bind to macromolecules such as DNA. PAH-DNA adducts have been associated with the induction of DNA mutations and cancer $(2,3)$ and represent a complex continuum including exposure, absorption, distribution, activation and detoxification, cell turnover and DNA repair. Therefore, DNA adducts were frequently measured in easily available white blood cells (WBC) or alveolar macrophages obtained by broncho- 
alveolar lavage (BAL) to assess human exposure to PAH. DNA adduct formation in these tissues was found to vary significantly between individuals with apparently similar exposures. Genetic polymorphisms in genes that encode for metabolizing enzymes are thought to be involved (4).

Detoxification of $\mathrm{PAH}$ is mediated by M1-class glutathione-S-transferases (GSTM1) (5). Glutathione (GSH) has a slow spontaneous rate of reaction with activated PAH. This rate can be enhanced by GSTM1-1. When the electrophile forms a covalent bond with GSH, it can easily be excreted and is no longer toxic. The GSTM1 gene locus is polymorphic; deficiency in this enzyme is caused by inheritance of a homozygous deletion of the GSTM1 gene [indicated as GSTM1(-/-), individuals with at least one expressing allele are indicated as GSTM1(+)] (5). It is repeatedly reported that subjects with low/no activity of GSTM1-1 or subjects with the GSTM1 $(-/-)$ genotype may have an increased risk for developing squamous cell carcinoma of the lung (6-8). Furthermore, the effect of GSTM1(-/-) seemed to be more predominant in heavy smokers than in light smokers $(9,10)$. Also, an association between GSTM1-1 expression and lung adenocarcinoma was reported by Seidegård (11), but genotyping studies could not confirm this (6). Furthermore, subjects lacking the GSTM1 locus seem to have higher PAH-DNA adduct levels in lung $(5,12-14)$. In peripheral blood cells such a relationship could not consistently be established (15-18). When combined with other polymorphic genotypes, like CYP1A1 $(13,16)$ or N-acetyl transferase (NAT2) $(17,19)$, significant differences in DNA adduct levels in white blood cells (WBC) were found between GSTM1(-/-) and GSTM1(+) individuals, but again these observations were not consistent (18).

The NAT2 gene is also polymorphic in man and has been associated with an increased risk of developing certain cancers in smokers; slow acetylators with bladder cancer and rapid acetylators with colorectal cancer (20). Overall, Nacetylation of aromatic amines is generally considered to be a detoxifying mechanism, since it competes with $\mathrm{N}$-oxidation. However, in colorectal tissues $\mathrm{N}$ acetylation might activate rather than inactivate xenobiotics. Approximately half of the Western population is slowly acetylating (21), which was related to high levels of protein adducts caused by aromatic amines in smokers $(22,23)$. The NAT2 polymorphism seems to be more relevant at low exposures as compared to high levels of exposure (24).

In the present study, we examined the relationship between the GSTM1/NAT2 genotypes and aromatic DNA adducts, assessed by nuclease P1 enriched ${ }^{32} \mathrm{P}-$ postlabeling, in peripheral blood mononuclear cells (i.e., lymphocytes plus monocytes, MNC) and alveolar macrophages obtained from smoking individuals to investigate tissue specific effects of GSTM1 and NAT2.

\section{Materials \& Methods}

\section{Study population}

Blood of 70 smoking healthy Caucasian volunteers (males/females: 28/42) with an average age of $41 \pm 8$ years was analyzed. These individuals smoked 1 to 50 cigarettes per day (overall mean: $25 \pm 11$ cigarettes per day) and reported not to be 
occupationally exposed to aromatic compounds. In a subgroup of 22 individuals (age: $42 \pm 8,9$ males, 13 females) who smoked $26 \pm 13$ cigarettes per day, alveolar macrophages were obtained by broncho-alveolar lavages (BAL). Informed consent was obtained for all individuals

\section{Isolation of mononuclear blood cells}

Ten $\mathrm{ml}$ of peripheral blood was sampled by venapuncture into EDTA-tubes. Polymorphonuclear cells (granulocytes) were separated from mononuclear cells (monocytes plus lymphocytes) by centrifugation on lymphoprep (Lymphoprep ${ }^{\mathrm{TM}}$ $(1.077 \mathrm{~g} / \mathrm{ml})$, Nycomed, Oslo, Norway) according to Bøyum (25). The mononuclear cell-fraction was washed twice with PBS and stored at $-20^{\circ} \mathrm{C}$ until DNA isolation.

\section{Bronchoalveolar lavage (BAL) to obtain alveolar macrophages}

Bronchoscopy was performed under local anesthesia. The bronchoscope was put into the middle lobe bronchus and $50 \mathrm{ml}$ of sterile saline $\left(37^{\circ} \mathrm{C}\right)$ was instilled. Immediately, suction was applied and the effluent was collected in a plastic tube and placed on ice. This procedure was repeated three more times, using lavage volumes of $50 \mathrm{ml}$ each. The BAL-fluid was strained through two layers of $4 \times 4$ gauze into 50 $\mathrm{ml}$ conical tubes. Cells were collected by centrifugation $\left(4^{\circ} \mathrm{C}, 200 \mathrm{~g}, 5\right.$ minutes $)$, the cell-pellet was stored at $-20^{\circ} \mathrm{C}$ until DNA isolation.

\section{DNA isolation and ${ }^{32} P$-postlabeling}

DNA was purified by a standard phenol extraction procedure as described previously (26). The DNA was precipitated with two volumes of cold ethanol after addition of $1 / 30$ volume $3 \mathrm{M}$ sodiumacetate, $\mathrm{pH} 5.3$ and washed with $70 \%$ ethanol . Subsequently, DNA was dissolved in $2 \mathrm{mM}$ Tris, $\mathrm{pH} 7,4$. Concentration and purity were determined spectrophotometrically by absorbance at 230, 260 and $280 \mathrm{~nm}$. The final volume was adjusted to achieve a DNA-concentration of $2 \mathrm{mg} / \mathrm{ml}$. Subsequentiy, the NP1-enriched ${ }^{32} \mathrm{P}$-postlabeling assay was performed (26). Briefly, DNA $( \pm 10 \mu \mathrm{g})$ was digested into nucleotide monophosphates and treated with nuclease P1 for 40 minutes at $37^{\circ} \mathrm{C}$. Then, nucleotides were $5^{\prime}$-labeled with ${ }^{32} \mathrm{P}$ using T4-polynucleotide kinase (5.0 Units) for 30 minutes at $37^{\circ} \mathrm{C}$. Radiolabeled adduct nucleotide biphosphates were separated by chromatography on PEI-cellulose sheets (Machery Nagel, Germany). The following solvent systems were used: D1, 1 M $\mathrm{NaH}_{2} \mathrm{PO}_{4} \mathrm{pH} 6.5 ; \mathrm{D} 2,8.5 \mathrm{M}$ urea, $5.3 \mathrm{M}$ lithiumformate $\mathrm{pH} 3.5 ; \mathrm{D} 3,1.2 \mathrm{M}$ lithiumchloride, $0.5 \mathrm{M}$ Tris, $8.5 \mathrm{M}$ urea pH 8.0; $\mathrm{D} 4,1.7 \mathrm{M} \mathrm{NaH}_{2} \mathrm{PO}_{4} \mathrm{pH}$ 6.0. In each experiment, 3 standards of $\left[{ }^{3} \mathrm{H}\right] \mathrm{BPDE}$ modified DNA with known modification levels ( 1 per $10^{7}, 10^{8}, 10^{9}$ nucleotides) were run parallelly for quantitation purposes. Quantitation was performed by using phosphor imaging technology (Molecular Dynamics $^{\mathrm{TM}}$, Sunnyvale) with which detection limits of $<1$ adduct per $10^{9}$ nucleotides can be obtained. 


\section{Determination of genetic polymorphisms in GSTM1 and NAT2}

The GSTM1 genotype was determined using a polymerase chain reaction (PCR)based assay as described by Brockmöller et al. (27). PCR was carried out in a total volume of $50 \mu \mathrm{l}$, containing $0.2 \mu \mathrm{g}$ DNA, $0.2 \mathrm{mM}$ of each dNTP, $5 \mathrm{mM}$ Tris-HCl, 25 $\mathrm{mM} \mathrm{KCl}, 0.75 \mathrm{mM} \mathrm{MgCl} 2$ and $1 \mu \mathrm{M}$ of each primer. Exact information about the primers used can be found in Brockmöller et al. (27). After denaturation at $94^{\circ} \mathrm{C}$ for 4 min, $1.25 \mathrm{U}$ of Taq-polymerase (Pharmacia Biotech, Roosendaal, The Netherlands) was added, followed by 35 cycles of amplification. An aliquot of $10 \mu \mathrm{l}$ of the PCR product was analyzed on a $3 \%$ agarose gel for the presence of bands at $338 \mathrm{bp}$ (control) and 273 bp (GSTM1).

NAT2 genotyping was performed using standard PCR procedures (28). PCR was carried out in a volume of $100 \mu \mathrm{l}$, containing $10 \mathrm{mM}$ Tris- $\mathrm{HCl}(\mathrm{pH} 8.3), 50 \mathrm{mM} \mathrm{KCl}$, $1.0 \mu \mathrm{g}$ DNA, $0.2 \mathrm{mM}$ of each dNTP, $1 \mu \mathrm{g}$ of each primer and 2.5 Units of Taqpolymerase. DNA amplification was performed in 30 cycles. Digestion of $2 \mu \mathrm{l}$ of the PCR product was carried out in a volume of $40 \mu \mathrm{l}$, using the appropriate buffers and the restriction enzymes Msp I and KpnI, BamHI and TaqI, or DdeI. Digested samples were loaded on a $5 \%$ acrylamide gel containing ethidium bromide, run for 16 hours at $30 \mathrm{~V}$ and visualized and photographed under UV light. Classification of the subjects in fast, intermediate or slow acetylators was derived from the genotype data (29).

\section{Statistics}

Results are presented as mean and standard deviation. Parametric-tests [unpaired ttests ( 2 groups) or one-way ANOVA ( $>2$ groups)] were applied to evaluate statistical significances. $\mathrm{P}<0.05$ was considered significant.

\section{Results}

Distribution of genetic polymorphisms in NAT2 and GSTM1

The GSTM1(-/-) genotype was found in 34 out of 70 individuals $(49 \%)$. The 'slow','intermediate' and 'fast' acetylator genotypes were found in respectively $54 \%$ $(38 / 70), 39 \%(27 / 70)$ and $7 \%(5 / 70)$ of the total study population. For statistical reasons, the fast and intermediate acetylators were combined into one group of 32 individuals (refered to as fast acetylators). When both polymorphisms were combined, it was found that 18 slow acetylators had the GSTM1(+) genotype (26\% of total) and the other slow acetylators $(n=20)$ contained the GSTM1(-/-) genotype $(29 \%)$. The GSTM1(+) and GSTM1(-/-) genotypes were equally distributed over the remaining 32 fast acetylators ( 16 per group, i.e., $23 \%$ each) (Table I and II). The subgroup $(\mathrm{n}=22)$, in which additionally alveolar macrophages were analyzed for aromatic-DNA adduct levels, contained 13 slow acetylators $(59 \%)$, of which 8 individuals lacked the GSTM1 gene. In the group of fast acetylators ( $n=9), 3$ individuals were found to lack the GSTM1 gene (Table I and II). 
Table I. The effect of GSTM1 and NAT2 polymorphisms on aromatic-DNA adduct levels in MNC and BAL-cells (adjusted for age and sex) from smoking individuals.

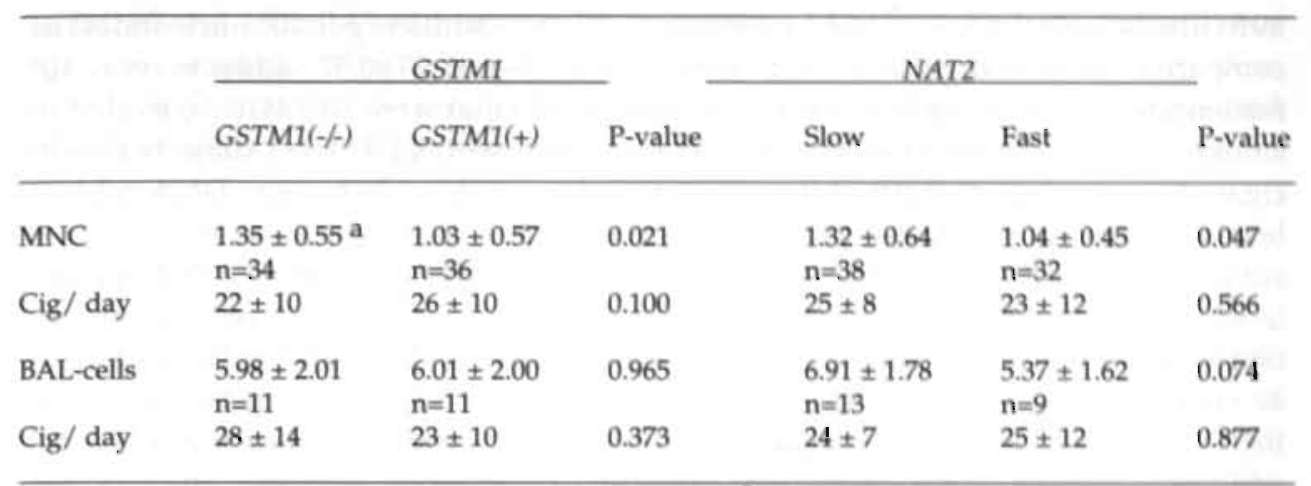

${ }^{\mathrm{a}}$ Mean \pm SD aromatic-DNA adduct level in adducts per $10^{8}$ nucleotides

Table II. The effect of combinations of GSTM1 and NAT2 genotypes on aromatic-DNA adduct levels (mean $\pm \mathrm{SD}$, in adducts per $10^{8}$ nucleotides) in MNC of smoking individuals.

\begin{tabular}{lll} 
& \multicolumn{1}{c}{$\operatorname{GSTM1}(-/-)$} & \multicolumn{1}{c}{$\operatorname{GSTM1}(+)$} \\
\cline { 2 - 2 } Slow Acetylators & $\begin{array}{l}1.45 \pm 0.61 \\
\mathrm{n}=20\end{array}$ & \multicolumn{1}{l}{$\begin{array}{l}1.17 \pm 0.65 \\
\mathrm{n}=18\end{array}$} \\
Fast Acetylators & $\begin{array}{l}1.22 \pm 0.43 \\
\mathrm{n}=16\end{array}$ & $\begin{array}{l}0.86 \pm 0.42^{*} \\
\mathrm{n}=15\end{array}$ \\
\hline
\end{tabular}

ANOVA: $\mathrm{P}=0.027, * \mathrm{P}=0.010$ as compared with GSTM1 (-/-)/ slow acetylators

DNA adducts in MNC and BAL cells

DNA adduct analysis in MNC and BAL-cells by thin layer chromatography resulted in DNA adduct profiles which are typical for exposure to cigarette smoke; so-called diagonal radioactive zones (DRZ) and results have been reported earlier by Godschalk et al. (1998). The mean DNA adduct level in MNC was 1.22 \pm 0.58 adducts per $10^{8}$ nucleotides and ranged from <detection limit (adduct level arbitrarily set on 0.25 per $10^{8}$ nucleotides) to 2.6 adducts per $10^{8}$ nucleotides. In BAL-cells, adduct levels were approximately 5-times higher as in MNC and a mean DNA adduct level of $5.93 \pm 2.42$ adducts per $10^{8}$ nucleotides (range: 2.44 11.00) was observed. A significant correlation was observed between the self-reported amount of cigarettes smoked per day and aromatic-DNA adduct levels in $\mathrm{MNC}(r=0.26, \mathrm{P}=0.035)$, but not in BAL-cells. 


\section{Impact of GSTM1 on DNA adduct levels in BAL cells and MNC}

Mean aromatic-DNA adduct levels in MNC were significantly higher in individuals with the GSTM1(-/-) genotype (1.35 \pm 0.55 adducts per $10^{8}$ nucleotides) as compared with individuals that were GSTM1 $(+)\left(1.03 \pm 0.57\right.$ adducts per $10^{8}$ nucleotides, $\mathrm{P}=0.021$, Table I). However, individuals that were GSTM1(-/-) tended to smoke less ( $22 \pm 10$ cigarettes per day) as compared with GSTM1 $(+)$ subjects $(26 \pm 10$ cigarettes per day, $\mathrm{P}=0.10$ ). After correction for smoking behavior, $\mathrm{DNA}$ adduct levels in MNC of GSTM1(-/-) individuals were still higher than those in GSTM1(+) subjects, but with 'borderline' significance only $(\mathrm{P}=0.062)$. Aromatic-DNA adduct levels in BAL-cells were not significantly related with the GSTM1 polymorphism; GSTM1(-/-) individuals showed similar DNA adduct levels in BAL-cells $(5.96 \pm 2.32)$ as compared with GSTM1 $(+)$ subjects $(5.89 \pm 2.68, \mathrm{P}=0.95)$. DNA adduct levels in BAL-cells were significantly correlated with age and gender (26), but even if these additional factors were taken into account, no relation between the GSTM1 polymorphism and DNA adduct formation in BAL-cells was observed ( $\mathrm{P}=0.96$, Table i).

Impact of NAT2 on DNA adduct levels in BAL cells and MNC

Mean DNA adduct levels in MNC of slow-acetylators (1.32 \pm 0.64 adducts per $10^{8}$ nucleotides) were higher as compared with fast acetylators $(1.04 \pm 0.45)$, which was in the same range as the effect observed for GSTM1 ( $\mathrm{P}=0.047$, Table I), but again the statistical significance was lost after adjustment for the amount of cigarettes smoked per day $(\mathrm{P}=0.067)$. At first, the NAT2-polymorphism did not seem to affect aromatic-DNA adduct levels in $\mathrm{BAL}-$-cells $(\mathrm{P}=0.41)$. However, after correction for age and gender, a more pronounced but nonsignificant difference between slowacetylators $(6.91 \pm 1.78)$ and fast acetylators $(5.37 \pm 1.62)$ was observed $(\mathrm{P}=0.07$, Table $\mathrm{I})$.

Table III. The effect of combinations of GSTM1 and NAT2 genotypes on aromatic-DNA adduct levels (mean $\pm \mathrm{SD}$, in adducts per $10^{8}$ nucleotides) in BAL-cells of smoking individuals.

\begin{tabular}{|c|c|c|}
\hline & GSTM1 (-/-) & $\operatorname{GSTM1}(+)$ \\
\hline Slow Acetylators. & $\begin{array}{l}6.68 \pm 1.72 \\
\mathrm{n}=8\end{array}$ & $\begin{array}{l}7.28 \pm 2.01 \\
n=5\end{array}$ \\
\hline Fast Acetylators & $\begin{array}{l}5.10 \pm 2.08 \\
n=3\end{array}$ & $\begin{array}{l}5.73 \pm 1.03 \\
n=6\end{array}$ \\
\hline
\end{tabular}

ANOVA: $\mathrm{P}=0.31$

Combinations of NAT2 and GSTM1 and their impact on DNA adduct levels

Highest mean aromatic-DNA adduct levels in MNC were observed in slow acetylators with the GSTM1(-/-) genotype (1.45 \pm 0.62 adducts per $10^{8}$ nucleotides) and lowest DNA adduct levels were found in individuals which were GSTM1(+) and 
fast acetylator $(0.86 \pm 0.42, \mathrm{P}=0.010)$. MNC of subjects which were GSTM1(-/ - ) / fast acetylator or GSTM1 $(+)$ /slow acetylator contained adduct levels of respectively $1.17 \pm 0.65$ and $1.22 \pm 0.43$ adducts per $10^{8}$ nucleotides (ANOVA, $\mathrm{P}=0.027$, Table II) but again, these results were no longer significant after adjustment for the smoking dose (ANOVA, $\mathrm{P}=0.08$ ). In BAL-cells, no association between combined genotypes and DNA adduct levels could be observed ( $\mathrm{P}=0.31$, Table III).

\section{Discussion}

It is thought that the balance between activation and inactivation of genotoxic compounds may play a significant role in the susceptibility towards the formation of DNA adducts and subsequent risk for developing chemically induced cancers. Thus, it is expected that the assessment of putative 'high risk genotypes' will allow the identification of cancer susceptible individuals or subgroups. In the present study, we investigated genetic polymorphisms in genes that encode for two phase II enzymes (i.e., GSTM1 and NAT2) in relation with the formation of aromatic-DNA adducts in MNC and BAL-cells of smoking individuals. The occurrences of these 'high risk genotypes' were in line with those reported for other Caucasian populations $(5,28)$. Exposure to tobacco smoke is a major risk factor for developing lung cancer, and epidemiological studies documented a dose-response relationship with the number of cigarettes smoked (30). Identically, a significant relationship was observed between the amount of cigarettes smoked per day and the level of aromatic-DNA adducts in MNC. However, the correlation coefficient was low $(r=0.26)$, which indicates that cigarette-dose alone is not sufficient to explain the observed variations in DNA adduct levels and genetic polymorphisms may be involved. Aromatic-DNA adduct levels in MNC of smoking GSTM1(-/-) subjects were modestly, but significantly higher than in GSTM1(+) individuals (1.27-fold). This is in agreement with several previous studies $(13,31)$, whereas others did not observe such an association $(15,18)$. After adjustment for the amount of cigarettes smoked per day, the observed difference between DNA adduct levels in MNC of GSTM1(-/-) and GSTM1(+) subjects was of 'borderline' significance. The influence of polymorphism in the GSTM1 gene on DNA adduct levels might be more pronounced when it is combined with other susceptibility genes, for instance the genetic polymorphism that has been found in the cytochrome P450 isoenzyme 1A1 (CYP1A1) (32). However, the literature regarding the impact of the inducible CYP1A1 genotype on aromatic-DNA adduct levels in WBC is still controversial (13, $16,31,33,34)$ and deserves further study. The CYP1A1 polymorphism is rare in Caucasian populations, and therefore, it is expected that the additional analysis of CYP1A1 in the present study would not have resulted in statistically informative results.

No association was observed between the GSTM1 polymorphism and aromatic-DNA adduct levels in BAL-cells of the same subjects, which indicates that the expression or the effect of genetic polymorphisms may not be similar in all tissues of an 
individual. Larger numbers of volunteers would have been required to find statistically significant differences.

Human exposure to PAH by inhalation of cigarette smoke always coincides with exposure to other aromatic compounds, such as aromatic amines. DNA adducts formed by aromatic amines are thought to be sensitive towards the action of nuclease P1, and might therefore remain undetected in this study. However, Gupta et al. (35) showed that aromatic amines bound to the exocyclic position of guanine can be detected by NP1 enriched 32P-postlabeling, which might explain the association between the NAT2 polymorphism and DNA-adduct formation in MNC and BALcells. A similar relationship was reported previously by Peluso et al. (19); higher adduct levels determined by NP1 enriched 32.P-postlabeling in slow acetylators as compared with fast acetylators. In a study by Hou et al. (17), an effect of the NAT2 polymorphism on DNA adduct levels was found only in combination with the GSTM1-genotype in bus maintenance workers. In our study, a possible involvement of both polymorphisms in tobacco smoke associated DNA adduct formation in MNC is also suggested.

Adduct levels in MNC and BAL-cells were lower in fast than in slow acetylators. This corresponds with the susceptibility towards bladder cancer (19), but not lung cancer. Most of the genotyping or phenotyping studies on lung cancer showed no overall risk related to acetylation capacities $(36,37)$. Nonetheless, individuals with high acetylation capacities might have an increased risk of lung cancer (38).

The results of the present study indicate that polymorphisms in GSTM1 and NAT2 may both be involved in interindividual differences in the formation of aromatic-DNA adducts in MNC. Their influence on adduct levels in BAL-cells need further study in larger study-populations. Nonetheless, the present study suggests that the NAT2 genotype is involved in adduct formation in BAL-cells of smoking individuals.

$* * * * * *$

\section{References}

1. IARC (1987) Overal! evaluation of carcinogenicity: an updating of IARC monographs 1-42. Monographs on the evaluation of the carcinogenic risk af chemicals to humans. IARC Sci. Publ. Suppl. 7

2. Hall, M., Grover, P.L. (1990) Polycyclic aromatic hydrocarbons: metabolism, activation and tumour initiation. In: Cooper, C.S., Grover, P.L. (eds) Chemical Carcinogenesis and Mutagenesis, Vol. I, pp 327-372, New York, USA, Raven Press.

3. Dennisenko, M.F., Pao, A., Tang, M., Pfeifer, G.P. (1996) Preferential formation of benzo[a]pyrene adducts at lung cancer mutational hotspots in P53. Science, 18, 430-432.

4. Bartsch, H., Hietanen, E. (1996) The role of individual susceptibility in cancer burden related to environmental exposure. Environ. Health. Persp., 104, suppl. 3, 569-577.

5. Ketterer, B., Harris, J.M., Talaska, G., Meyer, D.J., Pemble, S.E., Taylor, J.B., Lang, N.P., Kadlubar, F.F. (1992) The human glutathione S-transferase supergene family, its polymorphism and its effects on susceptibility to lung cancer. Environ. Health Perspect. 98, 87-94. 
6. Zhong, S., Howie, A.F., Ketterer, B., Taylor, J., Hayes, J.D., Beckett, G.J., Wathen, C.G., Wolf, C.R., Spurr, N.K. (1991) Glutathione S-transferase mu-locus: use of genotyping. and phenotyping assays to assess association. with lung cancer susceptibility. Carcinogenesis, 12, 1533-1537.

7. Hirvonen, A., Husgafvel-Pursiainen, K., Attila, S. Vainio, H. (1993) The GSTM1 null genotype as a potential risk modifier for squamous cell carcinoma of the lung. Carcinogenesis, 14, 1479-1481.

8. Seidegard, J., Pero, R.W., Miller, D.G., Beattie, E.J. (1986) A glutathione transferase in human leukocytes as a marker for the susceptibility to lung cancer. Carcinogenesis, 7, 751-753.

9. Kihara, M., Kihara, M., Noda, K., Okamoto, N. (1993) increased risk of lung cancer in japanese smokers with class mu glutathione S-transferase gene deficiency. Cancer Lett. 71, 151-155.

10. Nazar-Stewart, V., Motulsky, A.G., Eaton, D.L., White, E., Hornung, S.K., Leng, Z-.T., Stapleton, A.G., Weiss, N.S. (1993) The glutathione S-transferase $\mu$ polymorphism as a. marker for susceptibility to lung carcinoma. Cancer Res, 53, 2313-2318.

11. Seidegard, J., Pero, R.W., Markowitz, M.M.; Miller, D.G., Beattie, E.J. (1990) Isoenzymen(s) of glutathione transferase (class mu) as a marker for the susceptibility to lung cancer: A follow up study. Carcinogenesis, 11, 33-36.

12. Shields, P.G., Bowman, E.D., Harrington, A.M., Doan, V.T., Weston, A. (1993) Polycyclic aromatic hydrocarbon-DNA adducts in human lung and cancer susceptibility genes. Cancer Res., 53, 3486-3492.

13. Rojas, M., Alexandrov, K., Cascorbi, L., Brockmöller, J., Likhachev, A., Pozharisski, K., Bouvier, G., Auburtin, G., Mayer, L., Kopp-Schneider, A., Roots, I., Bartsch, H. (1998) High Beno[a]pyrene diol-epoxide DNA adduct levels in lung and blood cells from individuals with combined CYP1A1 Mspl/Mspl-GSTM1*0/*0 genotypes. Pharmacogenet. 8, 109-118.

14. Kato, S., Bowman, E.D., Harrington, A.M., Blomeke, B., Shields, P. (1995) Human lung carcinogen-DNA adduct levels mediated by genetic polymorphisms in vivo, I. Natl. Cancer Inst., 87, 902-907.

15. Grinsberg-Funes, R.A., Singh, V.N., Perera, F.P., Bell, D.A., Young, T.L., Dickey, C., Wang, L.W., Santella R.M. (1994) Polycyclic aromatic hydrocarbon-DNA adducts in smokers and their relationships to micronuclei levels and the glutathione S-transferase M1 genotype. Carcinogenesis, 15, 2449-2454.

16. Ishiba, M., Hagmar, L., Rannung, A., Hogstedt, B., Alexandrie, A.K., Cartensen, U., Hemminki, K. (1994) Aromatic-DNA adducts, micronuclei and genetic polymorphisms for CYP1A1 and GST1 in chimney sweeps, Carcinogenesis, 15, 1347-1352.

17. Hou, S.M., Lambert, B., Hemminki, K. (1995) Relationship between hprt mutant frequency, aromatic-DNA adducts and genotypes for GSTM1 and NAT2 in bus maintenance workers. Carcinogenesis, 16, 1913-1917.

18. Rothman, N., Shields, P.G., Poirier, M.C., Harrington, A.N., Ford, P., Strickland, P.T. (1995) The impact of glutathione-S-transferase M1 and Cytochrome P450 1A1 genotypes on white blood cell polycyclic aromatic hydrocarbon-DNA adduct levels in humans. Mol. Carcinogenesis, 14, 63-68.

19. Peluso, M., Airoldi, L., Armelle, M., Marlone T., Coda, R., Malaveille, C., Giacomelli, G., Terrone, C., Casetta, G., Vineis, P. (1998) White blood cell DNA adducts, smoking and NAT2 and GSTM1. genotypes in bladder cancer: a case-controle study. Cancer Epidemiol. Biomarkers and Prev., 7, 341-346.

20. D'Errico, A., Taioli, E., Chen, X., Vineis, P. (1996) genetic metabolic polymorphisms and the risk of cancer: A review of the literature. Biomarkers, 1, 149-173.

21. Shields, P.G. (1993) Inherited factors and environmental exposures in cancer risk. L. Occup. Med. 32, 34-41.

22. Vineis, P., Caporaso, N., Tannenbaum, S.R., Skipper, P.L., Glogowski, J., Bartsch, H., Coda, M., Talaska, G., Kadlubar, F.F. (1990) Acetylation phenotype, carcinogenheamoglobin adducts and cigarette smoking. Cancer Res.; 50, 3002-3004.

23. Yu, M., Skipper, P.L., Taghizadeh, K., Tannenbaum, S.R., Chan, K.K., Henderson, B.E. Ross, R.K. (1994) acetylator phenotype aminobiphenyl-hemoglobin adduct levels and 
bladder cancer risk in white, black, and Asian men in Los Angelos, California. L. Natl. Cancer Instit., 86, 712-716.

24. Vineis, P., Bartsch, H., Caporaso, N., Harrington, A.M., Kadlubar, F.F., Landi, M.T., Malaveille, C., Shields, P.G., Skipper, D., Talaska, G. (1994) Genetically based Nacetyltransferase metabolic polymorphism and low-level environmental exposure to carcinogens, Nature, 369, 154-156.

25. Boyum, A. (1976) Isolation of lymphocytes, granulocytes and macrophages. Scand. L. Immunol., 5, 9-15.

26. Godschalk, R.W.L., Maas, L.M., Van Zandwijk, N., Van 't Veer, L.J., Breedijk, A., Verhaert, J., Kleinjans, J.C.S., Van Schooten, F.J. (1998) Differences in aromatic-DNA adduct levels between alveolar macrophages and subpopulations of white blood cells from smokers. Carcinogenesis, 19, 819-825.

27. Brockmöller, J., Gross, D., Kerb, R., Drakoulis, N., Roots, L. (1992) Correlation between trans-stilbene oxide glutathione conjugation activity and the deletion mutation in the glutathione S-transferase class $\mathrm{Mu}$ gene detected by polymerase chain reaction. Biochem. Pharmacol., 43, 647-650.

28. Doll, M.A., Fretland, A.J., Deitz, A.C., Hein, D.W. (1995) Determination of human NAT2 acetylator genotype by restriction fragment length polymorphism and allelespecific amplification. Anal. Biochem., 321, 413-420.

29. Lin, H.J., Han, C-Y., Lin, B.K., Hardy, S. (1993) Slow acetylator mutations in the human polymorphic $\mathrm{N}$-acetyltransferase gene in 786 Asians, blacks, Hispanics and whites: application to metabolic epidemiology. Am. I. Hum. Genek., 52, 827-834.

30. Hoffmann, D., Hoffmann, L. (1997) The changing cigarette, 1950-1995. L. Tox. Environ. Health, 50, 307-364.

31. Butkiewicz, D., Grzybowska, E., Hemminki, K., Ovebro, S., Haugen, A., Motykiewicz, G., Chorazy, M. (1998) Modulation of DNA adduct levels in human white blood cells and granulocytes by CYP1A1, CYP2D6 and GSTM1 genetic polymorphisms. Mut. Res., 415, 97-108.

32. Kawajiri, K., Nakashi, K., Imai, K., Yoshii, A., Shinoda, N., Watanabe, J. (1990) Identification of genetically high risk individuals to lung cancer by DNA polymorphisms of the cytochrome P4501A1 gene. FEBS Lett., 263, 131-133.

33. Whyatt, R.M., Santella, R.M., Jedrychowski, W., Garte, S.J., Bell, D.A., Ottman, R., Gladek-Yarborough, A., Cosma, G., Young, T.L., Cooper, T.B., Randall, M.C., Manchester, D.K., Perera, F.P. (1998) Relationship between ambient air pollution and DNA damage in Polish mothers and newborns. Environ. Health. Perspect., 106 Suppl. 3, $821-826$

34. Hermminki, K., Dickey, C., Karlsson, S., Bell, D.A., Hsu, Y., Tsai, W.Y., Mooney, L.A., Savela, K., Perera, F.P. (1997) Aromatic DNA adducts in foundry workers in relation to exposure, life style and CYP1A1 and glutathione transferase M1 genotype. Carcinogenesis, 18, 345-350.

35. Gupta, R.C., Early, K. (1988) ${ }^{32}$ P-adduct assay: comparative recoveries of structurally diverse DNA adducts in the various enhancement procedures. Carcinogenesis, 9, 16871693.

36. Burgess, E.J., Treffort, J.A.P. (1985) Acetylator phenotype in patients with lung carcinoma: a negative report Eur. I. Respir. Dis., 67, 17-19.

37. Martinez, C., Agundez, J.A., Olivera, M., Martin, R., Ladero, J.M., Benitez, J. (1995) Lung cancer and mutations at the polymorphic NAT2 gene locus. Pharmacogenetics, 5 , 207-214.

38. Cascorbi, 1., Brockmoller, J., Mrozikiewicz, P.M., Bauer, S., Loddenkemper, R., Roots, I. (1996) Homozygous rapid arylamine $\mathrm{N}$-acetyl transferase (NAT2) genotype as a susceptibility factor for lung cancer. Cancer Res., 56, 3961-3966. 


\title{
Chapter 7
}

\section{Aromatic-DNA adducts in human white blood cells and skin after dermal application of coal tar}

\author{
R.W.L. Godschalk ${ }^{1}$, J.U. Ostertag ${ }^{2}$, E.J.C. Moonen ${ }^{1}$, \\ H.A.M. Neumann ${ }^{2}$, J.C.S. Kleinjans ${ }^{1}$, F.J. van Schooten ${ }^{1}$ \\ ${ }^{1}$ Department of Health Risk Analysis and Toxicology, \\ University of Maastricht, Maastricht, The Netherlands \\ 2 Department of Dermatology, \\ Academic Hospital Maastricht, Maastricht, The Netherlands.
}

Cancer Epidemiology, Biomarkers \& Prevention, vol. 7 pp 767-773, 1998.

\begin{abstract}
A group of eczema patients topically treated with coal tar ointments was used as a model population to examine the applicability of DNA adducts in white blood cell (WBC) subpopulations as a measure for dermal exposure to polycyclic aromatic hydrocarbons (PAH). Aromatic-DNA adducts were examined by ${ }^{32} \mathrm{P}$-postlabeling in exposed skin and WBC-subsets and urinary excretion of PAH-metabolites was determined to assess the whole body burden. Median urinary excretion of 1 hydroxypyrene and 3-hydroxybenzo[a]pyrene were respectively 0.39 (range: 0.12 1.57) and 0.01 (range: $<0.01-0.04) \mu \mathrm{mol} / \mathrm{mol}$ creatinine before dermal application of coal tar ointments. After treatment for one week, these levels increased to respectively 139.7 (range: 26.0-510.5) and 1.18 (range: <0.01-2.14), indicating that considerable amounts of PAH were absorbed. Median aromatic-DNA adduct levels were significantly increased in skin from 2.9 (range: 0.7-10.0) adducts per $10^{8}$ nucleotides before to 63.3 (range: 10.9-276.2) after treatment with coal tar, in monocytes from 0.28 (range: $0.25-0.81$ ) to 0.86 (range: $0.56-1.90$ ), in lymphocytes from 0.33 (range: $0.25-0.89$ ) to 0.89 (range: $0.25-3.01$ ) and in granulocytes from 0.28 (range: $0.25-0.67$ ) to 0.54 (range: $0.25-1.58$ ). A week after stopping the coal tar treatment, DNA adduct levels in monocytes and granulocytes were reduced to 0.38 (range: $0.25-0.71$ ) respectively 0.38 (range: $0.25-1.01$ ), while adduct levels in lymphocytes remained enhanced, 1.59 (range: 0.25-2.40). Although adduct profiles in skin and WBC-subsets were not identical and adduct levels in WBC were significantly lower as compared with skin, total DNA adduct levels in skin correlated significantly with adduct levels in monocytes and lymphocytes, but not in granulocytes. Excretion of urinary metabolites during the first week of treatment was correlated with the percentage of skin-surface treated with coal tar ointment and decreased to background levels within a week after cessation of treatment. 3Hydroxybenzo[a]pyrene excretion, but not 1-hydroxypyrene, correlated significantly with levels of DNA adducts in skin that comigrated with benzo[a]pyrene-diol-epoxide-DNA. This study indicates that DNA adduct levels in mononuclear WBC can possibly be used as a surrogate for skin DNA adduct levels after dermal exposure to $\mathrm{PAH}$.
\end{abstract}




\section{Introduction}

Coal tar is a complex chemical mixture containing high concentrations of polycyclic aromatic hydrocarbons (PAH), some of which have been found to be carcinogenic in laboratory animals and are suspected to be carcinogenic for man (1). Excesses of cancer in skin and scrotum were found in groups of workers handling pitch, tar and oils, and these cohorts were mainly exposed to PAH via dermal absorption (2). Non-occupational dermal exposure to PAH predominantly occurs via coal tar based shampoos or cosmetics and in the treatment of skin diseases. For example, psoriasis or eczema patients are often treated by dermal application of coal. tar ointments. Since exposures to PAH may involve health risks, interest has risen in the development of biological markers to assess PAH-exposure in human populations. A well known example is measuring the excretion profiles of PAHmetabolites in urine, especially 1-hydroxypyrene (1-OH-pyrene) (3). However, levels of urinary PAH-metabolites give no direct information about the dose that actually interacts with DNA. The formation of these DNA adducts is thought to play a crucial role in the development of cancer and other degenerative diseases (4). Nowadays, the ${ }^{32} \mathrm{P}$-postlabeling procedure has emerged as a sensitive tool to assess aromatic DNA adduct levels in small quantities of DNA, which makes this assay suitable for human studies when limited material is available e.g. biopsy samples. In tissues of laboratory rodents topically treated with PA.H-containing complex mixtures, high levels of aromatic-DNA adducts determined by ${ }^{32} \mathrm{P}$-postlabeling were found in skin and internal organs (e.g. lung and heart), whereas adduct levels in WBC were low as compared with tissue levels (5). PAH-DNA adducts were also detectable by ${ }^{32} \mathrm{P}$-postlabeling and by immunological assays in human skin treated with coal tar based ointments (6-8). In humans, however, internal organs are not readily accessible and therefore white blood cells (WBC) are often used as surrogate source of DNA. WBC-subpopulations (monocytes, lymphocytes and granulocytes) vary in metabolic and repair capacity, life span and relative quantities among one another and as compared with other cells/organs. Therefore, it is still controversial whether WBC or specific WBC-subsets reflect the binding of aromatic compounds to the DNA of tissues in which eventually tumors will be induced. Although reports that investigated a possible link between therapeutic use of coal tar and increased cancer rates are not conclusive (9), coal tar treated patients form a proper study population to investigate the relationship between target and surrogate source of: DNA, since the potential target tissue (i.e. skin) can easily be obtained by biopsy. Other studies focused on DNA adduct levels in WBC and predominantly lung-tissue from smokers. Overall, in studies that used total white blood cell DNA no significant. correlations were observed. $(10,11)$, whereas DNA adduct levels in mononuclear blood cells seemed to indicate the biologically effective dose in lung tissue more reliably (12). So, understanding the possibilities and limitations of DNA adduct analysis in WBC subpopulations may increase their applicability as a measurement for exposure to $\mathrm{PAH}$ and to estimate adduct levels in nonavailable organs. Therefore, we investigated aromatic DNA adduct levels in WBC-subpopulations (monocytes, granulocytes and lymphocytes) and skin-biopsies of ten eczema patients 
before and after treatment with coal tar ointments covering 20-86\% of their bodysurface. Furthermore, urinary excretion of 1-OH-pyrene and 3hydroxybenzo[a]pyrene (3-OH-B[a]P) was assessed as indicators for the whole body dose.

\section{Materials \& Methods}

\section{Sample collection of patients treated with coal tar based ointments}

Three male and 7 female diagnosed atopic eczema patients (age $34 \pm 5$ yr., range: 18 52 yr.) were treated with coal tar ointments for $21 \pm 9$ days (range: 7-33 days), covering $20-86 \%$ of their body surface. Treatment started twice a day with $3 \%$ pix lithantracis in petrolatum or in $10 \%$ zinc oxide plus $90 \%$ petrolatum during the first 2-3 days. In all cases, this treatment was well-tolerated and was intensified by applying twice a day $5 \%$ pix lithantracis in petrolatum/zinc oxide-petrolatum for another 2-3 days. Subsequently, a 10\% coal tar ointment was applied until the patient was discharged from the hospital. After informed consent, punch biopsies (4 $\mathrm{mm}$ ) were obtained under local anesthesia, before treatment $(t=0)$ and after one week of continuous application of coal tar ointments $(t=7)$ from treated areas. Biopsy samples were stored at $-20^{\circ} \mathrm{C}$ until DNA isolation. Ten $\mathrm{ml}$ of peripheral blood were obtained by venapuncture at several time points: before treatment $(t=0)$, at 7 days of continuous treatment $(t=7)$ and 7 days after the end of treatment $(t=7 x)$. Polymorphonuclear cells (granulocytes) were separated from mononucleated white blood cells (MNC, i.e. monocytes plus lymphocytes) by gradient centrifugation on lymphoprep according to Bøyum (13). Both fractions were washed with PBS. The granulocyte fraction was treated with lysis buffer $\left(155 \mathrm{mM} \mathrm{NH} \mathrm{Cl}_{4}, 10 \mathrm{mM} \mathrm{KHCO}\right.$, $10 \mathrm{mM}$ EDTA, pH 7.4) to lyse the erythrocytes, and subsequently washed with PBS. Monocytes and lymphocytes were resuspended in medium (RPMI 1640 supplemented with $10 \%$ FCS, $2 \mathrm{mM} \mathrm{L-glutamin,} 10 \mathrm{IU} / \mathrm{ml}$ penicillin and $10 \mu \mathrm{g} / \mathrm{ml}$ streptomycin) at a concentration of ca. $1 \times 10^{6}$ cells per $\mathrm{ml}$ and separated by adherence of monocytes to plastic T.C.-flasks for 40 minutes at $37^{\circ} \mathrm{C}$. Cells were stored at $-20^{\circ} \mathrm{C}$ until DNA-isolation. Morning urine was obtained at $\mathrm{t}=0, \mathrm{t}=1, \mathrm{t}=7$ and $\mathrm{t}=7 \mathrm{x}$ and stored at $-20^{\circ} \mathrm{C}$ for analysis of the urinary metabolites $1-\mathrm{OH}$-pyrene and 3$\mathrm{OH}-\mathrm{B}[\mathrm{a}] \mathrm{P}$.

\section{PAH content of coal tar (pix lithantracis) based ointments}

To determine the PAH levels of the coal tar ointments with which the patients were treated, extracts of the ointments were analyzed for the 16 EPA-listed PAH. First, 0.2. $\mathrm{g}$ ointment was extracted 5 times with $3 \mathrm{ml}$ hexane. Fractions were pooled and hexane was added to obtain a final volume of $50 \mathrm{ml}$. Subsequently, 200-500 $\mu \mathrm{l}$ were cleaned-up using a $0.5 \mathrm{~g}$ silica-column (V: $5 \mathrm{~mm}$ ). After evaporation of the eluate, the residue was dissolved in acetonitrile and concentrations of the EPA-listed PAH were measured by reversed-phase HPLC with fluorescence detection using excitation and emission wavelengths of respectively $250 \mathrm{~nm}$ and $>350 \mathrm{~nm}$ as described by Van Maanen et al. (14). The individual PAH congeners were identified and quantitated by comparing retention times and peak areas with those of selected standards. Since 
all ointments were based on pix linthantracis, similar PAH profiles were found for the different ointments $(3 \%, 5 \%$ and $10 \%)$. The relative distribution of $\mathrm{PAH}$ concentrations per percent of pix lithantracis was respectively naphthalene: $375 \pm 23$ (in $\mathrm{mg} / \mathrm{kg}$ ), acenaphthylene: not detected, acenaphthene: $120 \pm 9$, fluorene: $15 \pm 21$, phenanthrene: $63 \pm 4$, anthracene: $17 \pm 10$, fluoranthene: $80 \pm 6$, pyrene: $60 \pm 4$, benzo[a]anthracene: $43 \pm 3$, chrysene: $55 \pm 4$, benzo[b]fluoranthene: $53 \pm 5$, benzo[k]fluoranthene: $23 \pm 1$, benzo[a]pyrene: $52 \pm 3$, dibenzo[a,h] anthracene: $74 \pm 8$, benzo[g,h,i]perylene: $51 \pm 3$, indeno[1,2,3-c,d]pyrene: $24 \pm 22$.

\section{DNA isolation}

Biopsy samples were cut into small pieces and lysed overnight with $2.5 \mathrm{ml} \mathrm{SDS} \mathrm{(1 \% ),}$ followed by treatment with RNase A $(100 \mu \mathrm{g} / \mathrm{ml})$ and T1 $(50 \mathrm{U} / \mathrm{ml})$ for 30 minutes, then proteinase $\mathrm{K}$ was added to obtain a final concentration of $1 \mathrm{mg} / \mathrm{ml}$ and incubated at $37^{\circ} \mathrm{C}$ for 4 hours. WBC-subpopulations were lysed with $2.5 \mathrm{ml}$ SDS/NEP ( $75 \mathrm{mM} \mathrm{NaCl}, 25 \mathrm{mM}$ EDTA, $50 \mu \mathrm{g} / \mathrm{ml}$ proteinase $\mathrm{K}, 1 \% \mathrm{SDS}$ ) and incubated for 4 hours at $37^{\circ} \mathrm{C}$. Samples were extracted with phenol: chloroform: isoamylalcohol $(25: 24: 1, \mathrm{v} / \mathrm{v} / \mathrm{v})$ and chloroform: isoamylalcohol $(24: 1, \mathrm{v} / \mathrm{v})$ respectively. DNA was precipitated with two volumes of cold ethanol after addition of $1 / 30$ volume $3 \mathrm{M}$ sodium acetate, $\mathrm{pH} 5.3$ and washed with $70 \%$ ethanol. Subsequently, DNA was dissolved in $2 \mathrm{mM}$ Tris, $\mathrm{pH} 7,4$. Concentration and purity were determined spectrophotometrically by absorbance at 230,260 and $280 \mathrm{~nm}$. The final volume was adjusted to achieve a DNA-concentration of $2 \mathrm{mg} / \mathrm{ml}$.

\section{2 -postlabeling}

The ${ }^{32} \mathrm{P}$-postlabeling assay was performed as described by Reddy and Randerath (15) with some modifications. DNA $(10 \mu \mathrm{g})$ was digested using micrococcal endonuclease $\left(0.4\right.$ Units) and spleen phosphodiesterase $(2.8 \mu \mathrm{g})$ for 3 hours at $37^{\circ} \mathrm{C}$. Subsequently, half of the digest was treated with nuclease P1 $(6.3 \mu \mathrm{g})$ for 40 minutes at $37^{\circ} \mathrm{C}$. The modified nucleotides were labeled with $\left[\gamma^{32} \mathrm{P}\right]-\mathrm{ATP}(50 \mu \mathrm{Ci} /$ sample) by incubation with T4-polynucleotide kinase (5.0 Units) for 30 minutes at $37^{\circ} \mathrm{C}$. $\left[\gamma^{-32} \mathrm{P}\right]-\mathrm{ATP}$ was synthesized in the laboratory using carrier free ${ }^{32} \mathrm{P}$ (Dupont, Brussels). NP1efficiency and ATP-excess were checked with an aliquot of the NP1 treated fraction by one-dimensional chromatography on poly(ethyleneimine) (PEI)-cellulose sheets from Merck, Germany (solvent: $0.12 \mathrm{M} \mathrm{NaH}_{2} \mathrm{PO}_{4} \mathrm{pH}$ 6.8). Radiolabeled adduct nucleotide biphosphates were separated by chromatography on PEI-cellulose sheets from Machery Nagel (Germany). The following solvent systems were used: D1, $1 \mathrm{M}$ $\mathrm{NaH}_{2} \mathrm{PO}_{4} \mathrm{pH}$ 6.5; D2, $8.5 \mathrm{M}$ urea, $5.3 \mathrm{M}$ lithium formate $\mathrm{pH}$ 3.5; D3, $1.2 \mathrm{M}$ lithium chloride, 0.5 M Tris, $8.5 \mathrm{M}$ urea $\mathrm{pH} 8.0$; $\mathrm{D} 4,1.7 \mathrm{M} \mathrm{NaH}_{2} \mathrm{PO}_{4} \mathrm{pH}$ 6.0. In each experiment, 3 standards of $\left[{ }^{3} \mathrm{H}\right] \mathrm{BPDE}$ modified DNA with known modification levels ( 1 per $10^{7}, 10^{8}, 10^{9}$ nucleotides) were run in parallel for quantification purposes. Quantification was performed by using phosphor-imaging technology (Molecular Dynamics TM, Sunnyvale, CA, USA) with a detection limit of $<1$ adduct per $10^{9}$ nucleotides. The remaining half of the digest was used to determine the final amount of DNA in the assay; the normal nucleotides (nt.) were labeled with $\left[\gamma^{-32} \mathrm{P}\right]-$ $\operatorname{ATP}(15 \mu \mathrm{Ci} /$ sample) by incubation with T4-polynucleotide kinase ( $2.5 \mathrm{Units})$ for 30 
minutes at $37^{\circ} \mathrm{C}$. Nucleotides were separated by one-dimensional chromatography on PEI-cellulose sheets from Merck (solvent: $0.12 \mathrm{M} \mathrm{NaH}_{2} \mathrm{PO}_{4} \mathrm{pH} 6.8$ ); samples with apparent protein or RNA contamination were discarded. A dAp standard (27.5 pmole/ $\mu \mathrm{l}$ ) was labeled in each experiment for quantification purposes. Cochromatography was studied by analyzing the distance between the radioactivitypeaks of the origin and the putative BPDE-DNA adduct, using ImageQuant software (Molecular Dynamics ${ }^{\mathrm{TM}}$, Sunnyvale, CA, USA). Mean interassay variation was $17 \%$ (range: $0.3 \%-47 \%$ ).

\section{Excretion of 1-OH-pyrene and 3-OH-B[a]P in urine}

Detection of 1-OH-pyrene and 3-OH-B[a]P in urine was performed as described by Jongeneelen et al. (3). The method consisted of enzymatic hydrolysis with Bglucuronidase and arylsulphatase, solid phase extraction on a Sep-pak C-18 cartridge and elution with methanol. Reversed phase HPLC (Kratos solvent delivery system; Column: Hypersil 5 ODS) and fluorescence detection (Perkin-Elmer LS-30) were employed, using excitation and emission wavelengths of $253 \mathrm{~nm}$ and $423 \mathrm{~nm}$ for 3 $\mathrm{OH}-\mathrm{B}[\mathrm{a}] \mathrm{P}$ and respectively $232 \mathrm{~nm}$ and $384 \mathrm{~nm}$ for 1-OH-pyrene. Peak area was used for quantification. Concentrations were corrected for creatinine excretion, which was measured using a diagnostic kit of Sigma (no. 555-A). The detection limit was $200 \mathrm{ng}$ 3-OH-B[a]P and $80 \mathrm{ng}$ 1-OH-pyrene per liter urine, using a signal / background ratio of 3. Day-to-day variation and intra-assay variation were respectively $14 \%$ and $6 \%$.

\section{Statistics}

Results are presented as median and range. Overall, due to the relatively small number of observations $(n=10)$, nonparametric-tests for paired samples were applied. Spearman rank correlations were used to assess the relationships between DNA adduct levels in blood cells, skin biopsy samples and urinary excretion of 1$\mathrm{OH}$-pyrene and 3-OH-B[a]P. P $<0.05$ was considered significant.

\section{Results}

\section{Adduct profiles and levels in skin biopsies and WBC.}

After one week of treatment with coal tar ointments, aromatic-DNA adducts were readily detectable by ${ }^{32} \mathrm{P}$-postlabeling in skin DNA as well as in DNA obtained from WBC-subpopulations. Adduct profiles in skin and $W B C$, however, were not completely identical. As shown in Figure 1, in both skin and WBC DNA an adduct was found that comigrated with the [ $\left.{ }^{3} \mathrm{H}\right] \mathrm{BPDE}-\mathrm{DNA}$ adduct standard. Furthermore, in skin a diagonal radioactive zone (DRZ) was detected with high levels of radioactivity close to the origin. Whereas, in WBC no clear DRZ's were seen, but distinct adducts also other than the putative BPDE-DNA were seen at the upper right corner of the TLC-plates (Figure 1). No adduct spots or DRZ's could be detected in WBC subpopulations before treatment with coal tar ointments, except for one individual who smoked 10 cigarettes per day. On the other hand, in all skin-samples before treatment an adduct spot was detectable (Figure 1). Quantitatively, median DNA adduct levels in skin were ca. 20-fold 


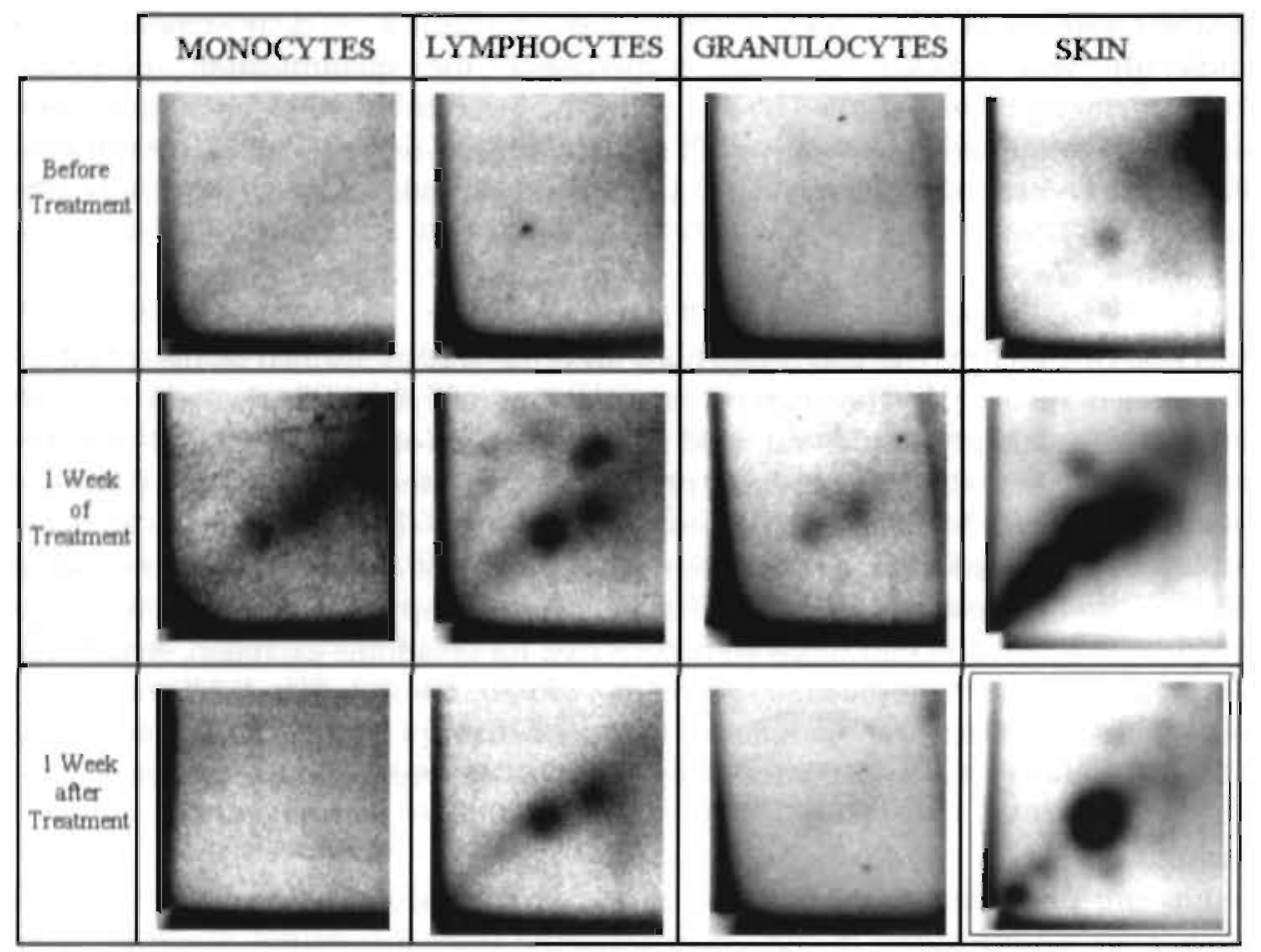

Figure 1. DNA adduct profiles obtained by ${ }^{32} \mathrm{P}$-postlabeling in WBC-subpopulations and skin DNA at $t=0$ (before treatment), $t=7$ (after 1 week of treatment) and $t=7 \times$ ( 1 week after stopping treatment). Origins are located at the lower left corner of each panel and were excised before analysis. Panel at the lower right corner of figure represents a [ $\left.{ }^{3} \mathrm{H}\right] \mathrm{BPDE}-\mathrm{DNA}$ adduct standard with a modification level of 1 adduct per $10^{7}$ nucleotides.

increased due to treatment for one week (respectively 2.89 (range: 0.66-10.04 adducts per $10^{8} \mathrm{nt}$. before and 63.3 (range: 10.9-276.2) after treatment with coal tar, $\mathrm{p}=0.005$ ). Furthermore, DNA adduct levels were increased in monocytes (0.28 (range: 0.25 0.81 ) vs. 0.86 (range: $0.56-1.90$ ), $\mathrm{p}=0.04$ ), lymphocytes $(0.33$ (range: $0.25-0.89$ ) vs. 0.89 (range: $0.25-3.01, \mathrm{p}=0.04$ ) and granulocytes (0.28 (range: $0.25-0.67$ ) vs, 0.54 (range: 0.25-1.58), $\mathrm{p}=0.05)$. Cessation of coal tar treatment for one week resulted in a significant reduction of DNA adduct levels in monocytes (0.38 (range: $0.25-0.71))$ and granulocytes (0.38 (range: $0.25-1.01)$ ), but adduct levels in lymphocytes were still elevated (1.59 (range: 0.25-2.40) (Table I and Figure 2). 


\section{Relationship between various parameters}

Although the number of volunteers was low $(n=10)$, a clear effect of gender on aromatic DNA adduct levels in skin DNA after treatment with CT-ointments was found; in males, median adduct levels (13.6 (range: 10.9-47.1), $\mathrm{n}=3,70 \pm 21 \%$ of skin surface was treated) were ca. 8 times lower as compared with female volunteers (106.7 (range: $23.1-276.2$ ), $n=7, p=0.03,65 \pm 24 \%$ of skin surface was treated). Analysis of the relationship between skin and WBC showed that total DNA adduct levels in skin were related to adduct levels in lymphocytes $\left(r_{\mathrm{S}}=0.65, \mathrm{p}<0.001\right)$ and monocytes $\left(r_{S}=0.74, p=0.005\right)$, but not with granulocytes $\left(r_{S}=0.44, p=0.07\right)$ (Figure 3$)$. The absence of a relationship with granulocyte-DNA can be explained by the observation that adduct levels in granulocytes were only increased above background in individuals that were treated. with coal tar ointment for $>70 \%$ of their body surface $(6 / 10)$, whereas adducts in skin were increased in all individuals irrespective of the percentage of treated body surface. Dose-responses (percentage of treated skin surface as measure of dose, since the amount of ointment per surface area was constant) were observed if adduct levels before treatment were included in the analysis (monocytes: $r=0.61, p=0.034$, lymphocytes: $p=0.51, p=0.022$, granulocytes: $r=0.63, p=0.003$ ). However, after exclusion of pre-treatment levels from the analysis, with increasing dose no clear increased adduct levels were observed in WBC-subsets.

\section{Excretion of 1-OH-pyrene and 3-OH-B[a]P in urine}

Before treatment, median baseline urinary concentrations of 1.OH-pyrene and 3-OH-B[a]P were respectively 0.39 (range: 0.12-1.57) and 0.01 (range: <0.01-0.04) $\mu \mathrm{mol} / \mathrm{mol}$ creatinine. These levels were significantly increased after topical application of a $3 \%$ coal tar ointment for 1 day (96.5 (range: 21.5-493.2) and 0.45 (range: <0.01-1.59)). Continuation of treatment for one week was reflected by a further increased to respectively 139.7 (range: $26.0-510.5$ ) and 1.18 (range: <0.01-2.14), although these increases were not significant. Cessation of treatment resulted in a quick reduction of urinary concentrations of both PAH-metabolites (Table 1); after one week, concentrations were back to baseline levels. The excretion of 1-OH-pyrene and $3-\mathrm{OH}-\mathrm{B}[\mathrm{a}] \mathrm{P}$ during the first week $(\mathrm{t}=0,1$ and 7$)$ was related to the administered dose (expressed as percentage of skin-surface treated with coal tar ointment; 1-OHpyrene: $r_{\mathrm{S}}=0.80, \mathrm{p}<0.001$ and $\left.3-\mathrm{OH}-\mathrm{B}[\mathrm{a}] \mathrm{P}: \mathrm{r}_{\mathrm{S}}=0.63, \mathrm{p}=0.002\right)$, but after exclusion of the pretreatment levels from the analysis, these relationships were lost (1-OH-pyrene: $\mathrm{r}_{\mathrm{S}}=0.34, \mathrm{p}=0.23$ and $\left.3-\mathrm{OH}-\mathrm{B}[\mathrm{a}] \mathrm{P}: \mathrm{r}_{\mathrm{S}}=0.16, \mathrm{p}=0.70\right)$. Overall, $1-\mathrm{OH}$-pyrene and 3-OH$\mathrm{B}[\mathrm{a}] \mathrm{P}$ excretion were interrelated $\left(\mathrm{r}_{\mathrm{S}}=0.61, \mathrm{p}<0.001\right)$, but interindividual variations were observed and individuals with high levels of 1-OH-pyrene excretion did not necessarily have high 3-OH-B[a]P excretion. The ratio between 1-OH-pyrene and 3$\mathrm{OH}-\mathrm{B}[\mathrm{a}] \mathrm{P}$ concentrations showed inter-individual variation (range: 44-650), but no intra-individual variations (ratios at $\mathrm{t}=1$ and $\mathrm{t}=7$ were highly correlated; $\mathrm{r}_{\mathrm{S}}=0.92$, $\mathrm{p}<0.001)$. 
Table I. Overall results of ${ }^{32} \mathrm{P}$-postlabeling (adducts per $10^{8}$ nucleotides) and urinary excretion of 1$\mathrm{OH}$-pyrene or 3-OH-B[a]P ( $\mu \mathrm{mol}$ per mol creatinine) at several time points. Results are presented as median and range.

\begin{tabular}{|c|c|c|c|c|}
\hline & $\begin{array}{l}\text { Before } \\
\text { Treatment }\end{array}$ & $\begin{array}{l}1 \text { day of } \\
\text { Treatment }\end{array}$ & $\begin{array}{l}1 \text { week of } \\
\text { Treatment }\end{array}$ & $\begin{array}{l}1 \text { week after } \\
\text { Treatment }\end{array}$ \\
\hline \multicolumn{5}{|c|}{ DNA adducts in: } \\
\hline Skin & $2.9(0.7-10.0)$ & - & \multicolumn{2}{|l|}{$63.3(10.9-276.2)-$} \\
\hline Monocytes & $0.28(0.25-0.81)^{*}$ & - & \multicolumn{2}{|c|}{$0.86(0.56-1.90)^{H} 0.38(0.25-0.71)^{\#}$} \\
\hline Lymphocytes & $0.33(0.25-0.89)$ & . & $0.89(0.25-3.01)$ & $1.59(0.25-2.40)$ \\
\hline Granulocytes & $0.28(0.25-0.67)$ & - & $0.54(0.25-1.58)$ & $0.38(0.25-1.01)$ \\
\hline \multicolumn{5}{|c|}{ Urinary excretion of PAH-metabolites } \\
\hline 1-OH-pyrene & $0.39(0.12-1.57)$ & \multicolumn{3}{|c|}{$96.5(21.5-493.2) 139.7(26.0-510.5)$} \\
\hline 3-ОН-в[а]Р & $0.01(<0.01-0.04)$ & $0.45(<0.01$ & $1.18(<0.01-2.14)$ & $0.01(<0.01-0.05)$ \\
\hline
\end{tabular}

Overall $n=10$, except for ${ }^{*} n=6, " n=7$ and ${ }^{+} n=8$.

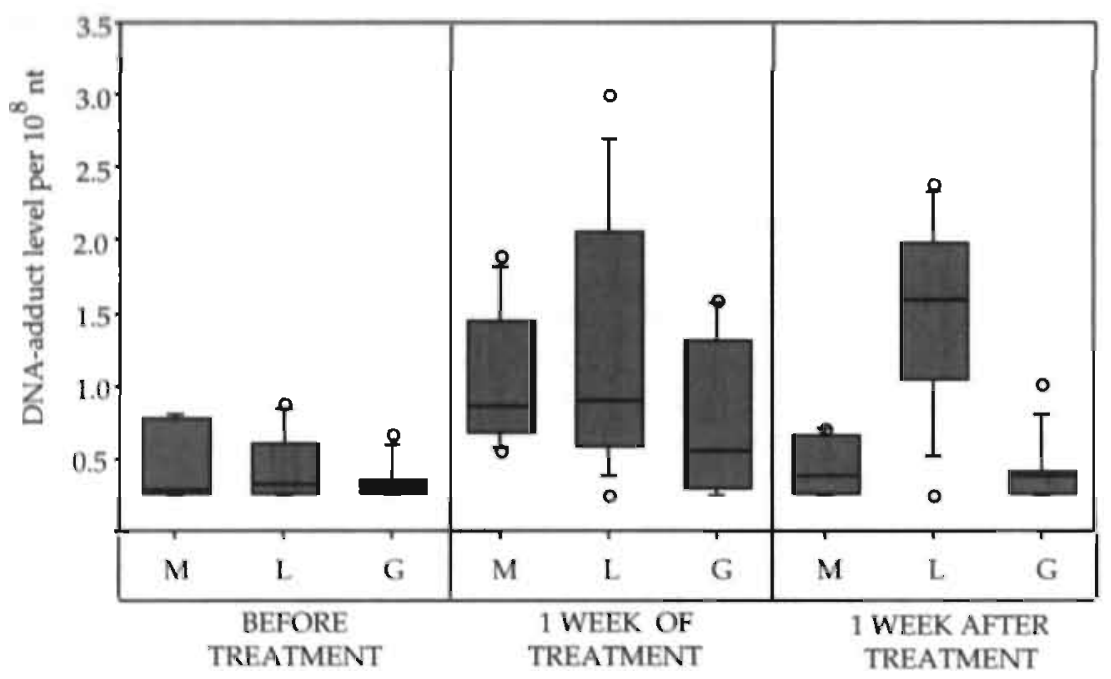

Figure 2. Aromatic-DNA adduct levels in WBC-subpopulations (monocytes $=\mathrm{M}_{n}$ lymphocytes $=\mathrm{L}$ and granulocytes $=\mathrm{G}$ ) at different time points, obtained by nuclease P1 enriched ${ }^{32} \mathrm{P}$-postlabeling. Boxes encompass the $25^{\text {th }}-75^{\text {th }}$ percentiles; middle lines, medians; whiskers, $10^{\text {th }}-90^{\text {th }}$ percentiles; 0 , values beyond $10^{\text {th }}$ or $90^{\text {th }}$ percentiles.

Urinary excretion of 1-OH-pyrene and 3-OH-B[a]P at the time of biopsy was not related to the total amount of DNA adducts in skin (1-OH-pyrene vs. DNA adducts in skin: $r_{S}=-0.2, p=0.55 ; 3-O H-B[a] P$ vs. DNA adducts in skin: $r_{S}=0.11, p=0.73$ ). However, the level of $3-\mathrm{OH}-\mathrm{B}[\mathrm{a}] \mathrm{P}$ excretion at the time of biopsy correlated significantly with the level of adducts in skin that comigrated with the BPDE-DNA adduct spot $\left(\mathrm{r}_{\mathrm{s}}=0.75, \mathrm{p}=0.025\right)$ (Figure 4$)$. 


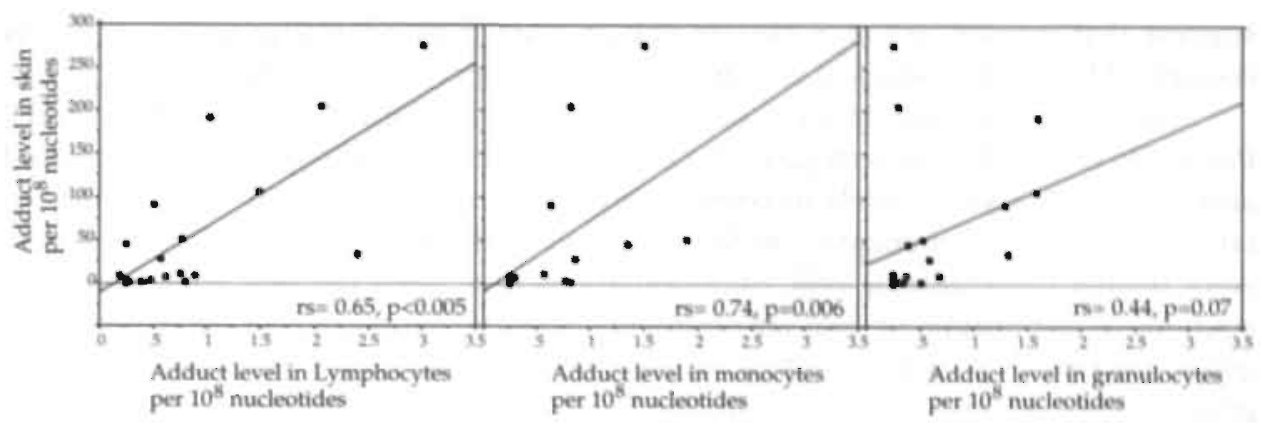

Figure 3. Quantitative relationship between DNA adduct levels in skin DNA and DNA obtained from WBC-subsets from the same individual, before and after treatment with coal-tar ointments. Relationship between lymphocytes and skin $\left(r_{\mathrm{s}}=0.65, p<0.005\right)$, monocytes and $\operatorname{skin}\left(r_{\mathrm{s}}=0.74, p=0.006\right)$, granulocytes and skin $\left(r_{\mathrm{s}}=0.44, p=0.07\right)$.

\section{Discussion}

In the present study, dermal application of coal tar based ointments significantly increased aromatic-DNA adduct levels in human skin and WBCsubpopulations. Although aromatic DNA adduct levels in WBC subpopulations were lower as compared to DNA adduct levels in skin, significant correlations were observed between adduct levels in peripheral blood lymphocytes or monocytes and skin-DNA. Furthermore, DNA adducts in monocytes and granulocytes were less persistent as compared with adducts in the lymphocyte fraction. Urinary excretion of monohydroxylated $\mathrm{PAH}$-metabolites indicated that large amounts of PAH were absorbed, and the levels of 3-OH-B[a]P excretion correlated with the level of the putative BPDE-DNA adduct in skin DNA.

After topical application of coal tar for one week, diagonal radioactive zones (DRZ) were observed in skin DNA, indicating a broad spectrum of different aromatic-DNA adducts. Also, an adduct spot that comigrated with the $\left.{ }^{3} \mathrm{H}\right] \mathrm{BPDE}-$ DNA standard was found. Although chromatography on TLC is unable to identify adducts formed by complex mixtures, ${ }^{32} \mathrm{P}-\mathrm{HPLC}$ analysis of mouse skin DNA demonstrated that the retention time of the major coal tar induced adduct closely resembled that of the adduct formed by B[a]P (16). Quantitatively, aromatic DNA adduct levels were 10-fold higher as the levels previously reported in skin of coal tar treated psoriasis patients $(6,7)$. Although differences in exposure cannot be excluded, these adduct levels might be underestimated, because in the study of Zhang et al. (6) additional immunofluorescence techniques indicated that the adduct levels could be higher than 1 adduct per $10^{6} \mathrm{nt}$. Aromatic-DNA adduct levels were higher in female patients as compared with male patients. Similarly, enhanced adduct levels were reported in lung $(17,18)$ and cells obtained by bronchoalveolar lavage (19) of female smokers as compared with male smokers. In B[a]P treated skin of $\mathrm{C} 3 \mathrm{H}$-mice, the decay curves of anti-BPDE related DNA adducts was steeper in male as compared to female rodents (20). Thus, human as well as rodent studies 
suggest that women are at a greater risk of PAH induced malignancies, which is confirmed by epidemiological studies on smoking individuals $(21,22)$.

Although coal tar treated patients are highly dermally exposed to $\mathrm{PAH}$, Pavanello et al. (23) and Santella et al. (24) were unable to find significantly increased aromatic-DNA adduct levels in respectively lymphocytes, and total WBC from coal tar treated psoriasis patients. On the contrary, in the present study DNA adducts were readily detectable in WBC-subpopulations of eczema patients after 1 week of continuous application of coal tar ointments. After cessation of coal tar treatment, a quick decrease of aromatic-DNA adduct levels was found in monocytes and granulocytes, which is in line with the half-lives of these cell-types in peripheral blood (hours-days). In lymphocyte-DNA, aromatic-DNA adduct levels were still elevated after 1 week. Unfortunately, this period is too short to calculate the persistence of DNA adducts in lymphocytes. Results of Pavanello et al. (23) and Paleologo et al. (25) using ELISA for adduct quantitation, showed a significant reduction over a period of 2-5 months after the end of coal tar therapy. Similarly, Mooney et al. (26) estimated the half-life of tobacco-smoke related DNA adducts in lymphocytes between 9 to 13 weeks following smoking cessation.

The applicability of DNA adducts in WBC to assess exposure to carcinogens or as a measure of the biologically effective dose in relevant tissues is still a matter of debate. Most studies that tried to validate carcinogen-DNA adduct levels in WBC as a measure for adduct levels in potential target tissues focused on smoking individuals (10-12, 27). In the present study, coal tar exposed eczema patients were used as a model population and aromatic-DNA adduct levels in monocytes and lymphocytes, but not in granulocytes, were found to be significantly correlated with adduct levels in skin DNA. Aromatic-DNA adducts in granulocytes and monocytes disappeared quickly after cessation of exposure. Therefore, for biomonitoring purposes it might be important to use lymphocytes as a surrogate source of DNA with more persistent adduct levels. In all WBC subpopulations lower adduct levels were found as compared with adduct levels in skin DNA, which indicates that DNA adducts in WBC will probably result in an underestimation of the biologically relevant dose after dermal exposure to PAH-mixtures. Nonetheless, the results of the present study indicate that peripheral blood lymphocytes are probably a valid surrogate for estimating the levels of aromatic-DNA adducts in skin. However, influences of different exposure routes on adduct formation in target as well as surrogate DNA should be further investigated. Furthermore, no clear dose-response relationship was observed; adduct levels in monocytes and lymphocytes were increased in individuals with the lowest exposure (ca. $20 \%$ of their body-surface covered with coal-tar ointment), but did not further increase if higher exposures $(>70 \%)$ were applied. A possible explanation is that at low/moderate exposure levels, adduct formation is proportional to dose, but at higher levels saturation may occur as recently demonstrated in environmentally (28) and occupationally exposed subjects $(28,19)$ and smokers (19). 


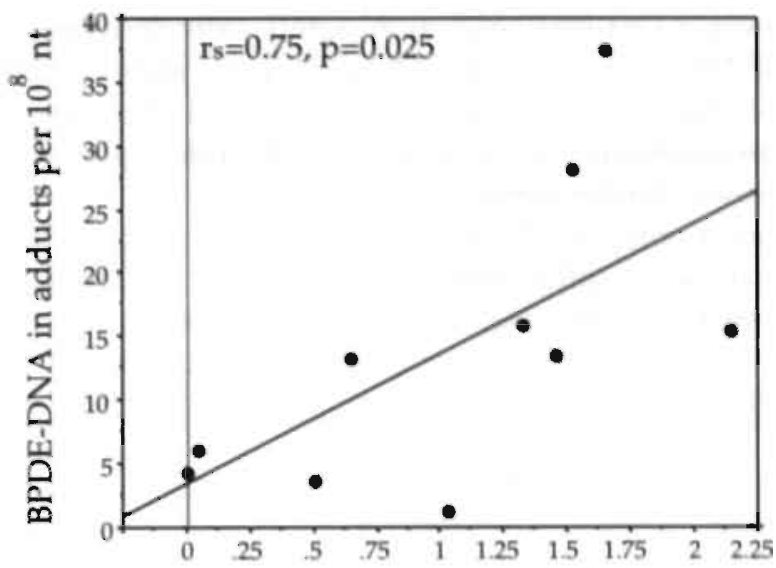

Urinary 3-OH-B[a]P in $\mu \mathrm{mol} / \mathrm{mol}$ creatinine

Figure 4. Relationship between putative BPDE-DNA adduct levels in skin DNA and the excretion of 3hydroxybenzo[a]pyrene at the time of biopsy.

The excretion of 1-OH-pyrene is considered to be a well established indicator for total exposure to $\mathrm{PAH}$ (3). As expected, urinary excretion of 1-OH-pyrene and 3$\mathrm{OH}-\mathrm{B}[\mathrm{a}] \mathrm{P}$ was increased after 1 day and 1 week of treatment. Even though $\mathrm{B}[\mathrm{a}] \mathrm{P}$ and pyrene were administered in nearly equal levels, the urinary levels of 1-OH-pyrene were more than 150 times greater than the levels of 3-OH-B[a]P. During the first week of exposure the level of excretion was correlated with the surface-area that was treated with coal tar ointment, but after exclusion of the pretreatment measurements $(t=0)$ from the analysis these relationships were lost. However, no corrections were made for differences between anatomical sites that may influence the total uptake of $\mathrm{PAH}$ and consequently concentrations of PAH-metabolites in urine (29). Furthermore, urinary concentrations of $\mathrm{PAH}$-metabolites may eventually decrease during continuation of coal tar treatment (30). The levels of 1-OH-pyrene excretion were higher in patients of the present study as compared with individuals that are occupationally exposed to PAH mixtures (31-33). Overall, the excretion of $1-\mathrm{OH}-$ pyrene was correlated with the excretion of $3-\mathrm{OH}-\mathrm{B}[\mathrm{a}] \mathrm{P}$, but individuals with the highest levels of 1-OH-pyrene excretion did not necessarily have high 3-OH-B[a]P excretion. Grimmer et al. (34) suggested that invariant interindividual differences in PAH metabolite profiles could possibly form a suitable tool to estimate the individual cancer risks at PAH exposed working places. An invariant PAHmetabolite profile may indicate an individual and invariant set of $\mathrm{PAH}$-metabolizing enzymes producing a certain ratio of carcinogenic and non-carcinogenic PAHmetabolites. Carcinogenic PAH may covalently interact with DNA, whereas noncarcinogenic metabolites are excreted in urine or feces. Therefore, a correlation between distinct urinary metabolites and DNA adduct formation can be expected. Indeed, in the present study the excretion profile of $1-\mathrm{OH}$-pyrene vs. $3-\mathrm{OH}-\mathrm{B}[\mathrm{a}] \mathrm{P}$ concentrations showed significant interindividual variation, but low intraindividual 
variations. Moreover, 3-OH-B[a]P excretion significantly correlated with the level of the putative BPDE-DNA adduct in skin DNA. Thus, it can be suggested that urinary profiles of monohydroxylated metabolites may reflect exposure to $\mathrm{PAH}$ and the binding of reactive metabolites to DNA, and may therefore play a role in cancer risk assessments. However, further confirmation is needed.

In conclusion, monitoring PAH-DNA adduct levels in mononuclear WBC by ${ }^{32} \mathrm{P}$-postlabeling can be a useful molecular index for the quantitative estimation of the biologically effective dose in relevant tissues. However, the sensitivity of DNA adducts in WBC subpopulations as a measure of exposure is limited. For that purpose, measurements of urinary $\mathrm{PAH}$-metabolites seem to be more sensitive.

$+\$+\$+\$$

\section{References}

1. IARC monographs on the evaluation of the carcinogenic risk of chemicals to man. Part 4, Polynuclear Aromatic Compounds: Bitumens, coal-tars and derived products, shale oils and soots. Volume 35. Lyon, 1985.

2. Mastrangelo, G., Fadda, E., Marzia, V. (1996) Polycyclic aromatic hydrocarbons and cancer in man. Environ. Health Perspect., 104, 1166-1170.

3. Jongeneelen, F.J., Bos, R.P., Anzion, R.B.M., Theuws, J.L., Henderson, P.T. (1986) Biological monitoring of polycyclic aromatic hydrocarbons. metabolites in urine. Scand. 1. Work Environ. Health, 12, 137-143.

4. De Flora, S., Izotti, A., Randerath, K., Randerath, E., Bartsch, H., Nair., J., Balansky, R., Van Schooten, F.J., Degan, P., Fronza, G., Walsh, D., Lewtas, J. (1996) DNA adducts and chronic degenerative diseases. Pathogenetic relevance and implications in preventive medicine. Mutat. Res., 366, 197-238.

5. Binkova, B., Dobiás, L., Wolff, T., Sram, R.J. (1994) ${ }^{32}$ P-postlabeling analysis of DNA addlucts in tissues of rats exposed to coke-oven emissions. Mutat. Res., 307, 355-363.

6. Zhang, Y.J., Li, Y., DeLeo, V.A., Santella, R.M. (1990) Detection of DNA adducts in skin biopsies of coal tar treated psoriasis patients: Immunofluorescence and 32Ppostlabeling. Skin Pharmacol., 3, 171-179.

7. Phillips, D.H., Schoket, B., Hewer, A. (1990a) DNA adduct formation in human and mouse skin by mixtures of polycyclic aromatic hydrocarbons. IARC scientific publications, 104, 223-229.

8. Schoket, B., Hewer, A., Grover, P.L., Phillips, D.H. (1988) Formation of DNA adducts in human skin maintained in short-term organ culture and treated with coal tar, creosote or bitumen. Int. I. Cancer, 42, 622-626.

9. Van Schooten, F.J. and Godschalk, R.W.L. (1997) Coal tar therapy; Is it carcinogenic?, Drug Safety, 15, 374-377.

10. Phillips, D.H., Schoket, B., Hewer, A., Bailey, E., Kostic, S., Vincze, I. (1990b) Influence of cigarette smoking on the level of DNA adducts in human bronchial epithelium and white blood cells. Int. J. Cancer, 46, 569-575.

11. Van Schooten, F.J., Hillebrand, M.J.X., van Leeuwen, F.E., van Zandwijk, N., Jansen, H.M., den Engelse, L., Kriek, E. (1992) Polycyclic aromatic hydrocarbon DNA adducts in white blood cells from lung cancer patients: no correlation with adduct levels in lung. Carcinogenesis, 13, 987-993.

12. Wiencke, J.K., Kelsey, K.T., Varkonyi, A., Semey, K., Wain, J.C., Mark, E., Christiani, D.C. (1995) Correlation of DNA adducts in blood mononuclear cells with tobacco carcinogen-induced damage in human lung. Cancer Res, 55, 4910- 4914.

13. Beyum, A.(1976) Isolation of lymphocytes, granulocytes and macrophages. Scand. I. Immunol., 5, 9-15. 
14. Van Maanen, J.M.S., Moonen, E.J.C., Maas, L.M., Kleinjans, J.C.S., van Schooten, F.J. (1994) Formation of aromatic DNA adducts in white blood cells in relation to urinary excretion of 1-hydroxypyrene during consumption of grilled meat. Carcinogenesis, 15, 2263-2268.

15. Reddy, M.V., Randerath, K. (1986) Nuclease P1 mediated enhancement of sensitivity of ${ }^{32} \mathrm{P}$-postlabeling test for structurally diverse DNA-adducts. Carcinogenesis, 7, 1543 1551.

16. Pfau, W., Lecoq, S., Hughes, N.C., Grover, P.L., Phillips, D.H. (1993) Seperation of 32Ppostlabelled nucleoside 3',5'-biphosphate adducts by HPLC, in: Phillips, D.H. Castegnaro, M., Bartsch, H. (Eds.) Postlabeling methods for detection of DNA adducts, IARC scientific publications, no. 124, 233-242.

17. Ryberg, D., Hewer, A., Phillips, D.H., Haugen, A. (1994) Different susceptibility to smoking induced DNA damage among male and female lung cancer patients. Cancer Res.,54, 5801-5803.

18. Kure, E.H., Ryberg, D., Hewer, A., Phillips, D.H., Skaug, V., Baera, R., Haugen, A. (1996) P53 mutations in lung tumours: relationship to gender and lung DNA adduct levels. Carcinogenesis, 17, 2201-2205.

19. Van Schooten, F.J., Godschalk, R.W.L., Breedijk, A., Maas, L.M., Kriek, E., Sakai, H., Wigbout, G., Baas, P., Van 't Veer, L., Van Zandwijk, N. (1997) 32P-postlabeling of aromatic DNA adducts in white blood cells and alveolar macrophages of smokers: Saturation at high exposures. Mutat. Res., 378, 65-75.

20. Shugart, L., Kao, J. (1985) Examination of adduct formation in vivo in the mouse between benzo(a)pyrene and DNA of skin and hemoglobin of red blood cells, Environ. Health Perspect., 62, 223-226.

21. Harris, R.E., Zang, E.A., Anderson, J.I., Wynder, E.L. (1993) Race and sex differences in lung cancer risk associated with cigarette smoking. Int. I. Epidemiol. 22, 592-599.

22. Risch, H.A., Howe, G.R., Jain, M., Burch, J.D., Holoway, E.J., Miller, A.B. (1993) Are female smokers at higher risk for lung cancer than male smokers? A case control analysis by histological type. Am. J. Epidemiol., 138, 281-293.

23. Pavanello, S., Levis, A.G. (1994) Human peripheral blood lymphocytes as a cell model to evaluate the genotoxic effect of coal tar treatment. Environ. Health Perspect., 102 Suppl. 9, 95-99.

24. Santella, R.M., Perera, F.P., Young, T.L., Zhang, Y., Chiamprasert, S., Tang, D., Wang, L.W., Beachman, A., Lin, J., DeLeo, V.A. (1995) Polycyclic aromatic hydrocarbon-DNA and protein adducts in coal tar treated patients and their relationship to glutathione-stransferase genotype. Mutat. Res., 334, 117-124.

25. Paleologo, M., van Schooten, F.J., Pavanello, S., Kriek, E., Zordan, M., Clonfero, E., Brezze, C., Levis, A.G. (1992) Detection of benzo[a]pyrene-diol-epoxide-DNA adducts in white blood cells of psoriatic patients treated with coal tar. Mutat. Res., 281, 11-16.

26. Mooney, L.A., Santella, R.M., Covey, L., Jeffrey, A.M., Bigbee, W., Randall, M.C., Cooper, T.B., Ottman, R., Tsai, W., Wazneh, L., Glassman, A.H., Young, T., Perera, F.P. (1995) Decline of DNA damage and other biomarkers in peripheral blood following smoking cessation. Cancer Epidemiol. Biomarkers and Prev., 4, 627-634.

27. Szyfter, K., Hemminki, K., Szyfter, W., Szmeja, Z., Banaszewski, J., Yang, K. (1994) Aromatic DNA adducts in larynx biopsies and leukocytes. Carcinogenesis, 15, 21952199.

28. Lewtas, J., Walsh, D., Williams, R., Dobiás, L.(1997) Air pollution exposure-DNA adduct dosimetry in humans and rodents: evidence for non-linearity at high doses. Mut. Res. 378, 51-63.

29. Van Rooij, J.G., De Roos, J.H., Bodelier-Bade, M.M., Jongeneelen, F.J. (1993) Absorption of polycyclic aromatic hydrocarbons through human skin: differences between anatomical sites and individuals. I. Toxicol. Environ. Health, 38, 355-368.

30. Hansen, A.M., Poulsen, O.M., Menne, T. (1993) Longitudinal study of excretion of metabolites of polycyclic aromatic hydrocarbons in urine of two psoriatic patients. Acta. Derm. Venereol., 73, 188-190.

31. Van Schooten, F.J., Jongeneelen, F.J., Hillebrand, M.J.X., Van Leeuwen, F.E., de Looff, A.J.A., Dijkmans, A.P.G., van Rooij, J.G.M., den Engelse, L., Kriek, E. (1995) Polycyclic 
aromatic hydrocarbon-DNA adducts in white blood cell DNA and 1-hydroxypyrene in the urine from aluminum workers: Relation with job category and synergistic effect of smoking, Cancer Epidemiol. Biomarkers \& Prev. 4, 69-77.

32. Elovaara , E., Heikkilä, P., Pyy, L., Mutanen, P., Riihimäki, V. (1995) Significance of dermal and respiratory uptake in creosote workers: exposure to polycyclic aromatic hydrocarbons and urinary excretion of 1-hydroxypyrene. Occup. Environ. Med., 52, 196-203.

33. Kuljukka, T., Vaaranrinta, R., Mutanen, P., Veidebaum., T., Sorsa., M., Kalliokoski, P., Peltonen, K. (1997) Assessment of occupational exposure to PAHs in an Estonian coke oven plant-correlation of total exposure to internal dose measured as 1-hydroxypyrene concentration, Biomarkers, 2, 87-94.

34. Grimmer, G., Jacob, J., Dettbarn, G., Naujack, K.-W., Heinrich, U. (1995) Urinary metabolite profile of $\mathrm{PAH}$ as a potential mirror of the genetic disposition for cancer. Exp. Toxic. Pathol. 47, 421-427. 


\title{
Chapter 8
}

\section{Impact of GSTM1 on aromatic-DNA adducts and P53 accumulation in human skin and lymphocytes}

\author{
R.W.L. Godschalk¹, J.U. Ostertag ${ }^{2}$, A.M.G. Zandsteeg ${ }^{1}$, E. van Agen1, \\ H.A.M. Neumann ${ }^{2}$, H. van Straaten ${ }^{3}$, F.J. van Schooten ${ }^{1}$ \\ ${ }^{1}$ Department of Health Risk Analysis and Toxicology, \\ University of Maastricht, Maastricht, The Netherlands \\ 2 Department of Dermatology, \\ Academic Hospital Maastricht, Maastricht, The Netherlands. \\ 3 Department of Anatomy and Embryology \\ University of Maastricht, Maastricht, The Netherlands
}

Submitted to the Journal of the National Cancer Institute

\begin{abstract}
Background: The cellular response to carcinogen induced DNA damage is often a p53-mediated cell cycle arrest to provide time for DNA repair or to direct damaged cells into apoptosis. We examined the impact of the GSTM1 polymorphism on DNA adduct levels and p53 accumulation in lymphocytes of healthy volunteers in vitro exposed to benzo[a]pyrene (B[a]P) diol-epoxide (BPDE) and in skin of atopic eczema patients before and after topical treatment with coal-tar ointments for one week. Methods: DNA adduct levels were determined by immunocytochemical staining (ICC) and 32P-postlabeling. P53 accumulation was studied by ICC. GSTM1 genotypes were assessed by PCR. Additionally in the eczema patients, the internal dose of polycyclic aromatic hydrocarbons was assessed by urinary 1-hydroxypyrene and 3-hydroxy-B[a]P excretion. Results: In cultured lymphocytes treated with 2.5 $\mu \mathrm{M}$ BPDE for 18 hours, increased levels of p53 were found, which were correlated with BPDE-DNA adduct levels assessed by ICC $\left(r_{\mathrm{s}}=0.66, P<0.001\right)$ and $32 \mathrm{P}$ postlabeling $\left(\mathrm{r}_{\mathrm{S}}=0.56, \mathrm{P}<0.001\right)$ and appeared to be higher in GSTM1 $(-/-)$ than in GSTM1 (+) subjects ( $\mathrm{P}=0.003$ ). In skin biopsies of eczema patients, median DNA adduct levels were increased from 2.9 adducts per $10^{8}$ nucleotides (range: $0.7-10.0$ ) before treatment, to 63.3 adducts per $10^{8}$ nucleotides (range: 10.9-276.2, $\mathrm{P}=0.005$ ) after treatment. P53 was elevated in 7/10 patients and a correlation was observed between $\mathrm{p} 53$ and DNA adduct levels $\left(\mathrm{r}_{\mathrm{5}}=0.50, \mathrm{P}=0.029\right)$. GSTM1(-/-) subjects. contained higher levels of p53 in the stratum basale than GSTM1(+) individuals $(\mathrm{P}=0.026)$, whereas the impact of GSTM1 on DNA adduct levels did not reach statistical significance. Moreover, highest urinary levels of 1-hydroxypyrene were found in GSTM1(+) patients, but no such effect was found on 3-hydroxy-B[a]P levels. Conclusion: These results indicate that p53 accumulation and GSTM1 may act in concert as protective mechanisms against PAH induced DNA damage in human cells.
\end{abstract}




\section{Introduction}

Polycyclic aromatic hydrocarbons (PAH) are well known ubiquitous environmental carcinogens, of which benzo[a]pyrene $\left(\mathrm{B}_{i}[\mathrm{a}] \mathrm{P}\right)$ is the most studied one. Benzolalpyrene-diol-epoxide (BPDE) is thought to be the ultimate carcinogenic metabolite of $\mathrm{B}[\mathrm{a}] \mathrm{P}$ and covalent interactions of BPDE with DNA may be involved in carcinogenesis (1). For instance, BPDE-DNA adduct formation in skin was correlated with the initiation of skin cancer in rodent models (2), and inhibition of adduct formation resulted in decreased carcinogenicity of B[a]P $(3,4)$. One of the cellular preventive mechanisms against chemically induced cancers is accumulation of p53, which inhibits the cell cycle to provide sufficient time for efficient DNA repair (5) and may also contribute to apoptosis $(6,7)$. Thus, p53 accumulation may prevent the onset of carcinogenesis by selection in favor of efficiently repaired cells, against heavily damaged cells. The important role of wild type p53 in prevention of human carcinogenesis is especially seen in individuals with inherited defects in one of the p53 alleles (Li-Fraumeni syndrome), who are predisposed to cancer (8). Also in animal models, mutant or absent $p 53$ gene alleles resulted in a higher frequency of spontaneous tumor development (9). Thus, p53 plays an important role in maintaining the integrity of the genome after damage has occurred.

In addition, DNA damage can be avoided by other preventive mechanisms. For example, DNA reactive compounds may be inactivated by glutathione; the electrophile covalently bound to glutathione can be excreted and is no longer toxic. This reaction is mediated via glutathione S-transferase M1 (GSTM1), which is known to be polymorphic in humans. The GSTM1 gene locus contains two expressing genes (1A and 1B) and a null allele (10). It is thought that the gene-product of GSTM1 is involved in the inactivation of epoxides like BPDE (11). Therefore, subjects with low/no activity of GSTM1-1 or subjects with the GSTM1 null allele may have increased aromatic DNA adduct levels in target cells $(10,12)$. Although in human skin, GST isoenzymes of the Mu-class are present in relatively low concentrations (13), in the stratum basale of normal human epidermis clear immunohistochemical staining for GST's of the Mu-class was observed (14).

In the present study, we investigated the relationship between the level of DNA damage induced by $\mathrm{PAH}$ and subsequent accumulation of $\mathrm{p} 53$, in vitro in cultured lymphocytes of healthy volunteers and in vivo in skin of eczema patients treated with coal-tar ointments for one week. Furthermore, the influence of the GSTM1 genotype on adduct formation and p53 accumulation was investigated. Urinary excretion of 1-hydroxypyrene and 3-hydroxy-B[a]P was determined in coal-tar treated patients to assess the whole body burden to $\mathrm{PAH}$.

\section{Materials \& Methods}

In vitro exposure of lymphocytes and slide preparation

Lymphocytes of 55 healthy volunteers ( 9 men, all nonsmokers; 46 women, 39 nonsmokers and 7 smokers; age ranged from 20 to 30 years) were isolated by 
gradient centrifugation from $10 \mathrm{ml}$ of heparinized venous blood as described by Bøyum (15). Cells were cultured (cell concentration 1×106/ml) in RPMI 1640 medium supplemented with $10 \%$ Fetal Calf Serum, L-glutamine, $100 \mathrm{U} / \mathrm{ml}$ penicillin and 100 $\mu \mathrm{g} / \mathrm{ml}$ streptomycin in the presence of $50 \mu \mathrm{g}$ phytoheamagglutinine $/ \mathrm{ml}$ medium. After 24 hours of incubation at $37^{\circ} \mathrm{C},( \pm)$-anti-benzo[a]pyrene-diol-epoxide (Midwest Research Institute, USA) was added at a final concentration of $2.5 \mu \mathrm{M}(\mathrm{n}=44)$, or DMSO was added as a negative control $(n=11)$ and incubations were continued for 18 hours at $37^{\circ} \mathrm{C}$. After the incubations, cells were washed with ice-cold PBS and hypotonized with $75 \mathrm{mM} \mathrm{KCl}$ for $30 \mathrm{~min}$ at $4^{\circ} \mathrm{C}$. Nuclei were fixed by adding methanol: acetic acid (3:1), and were pipetted on microscope-slides. Slides were airdried overnight.

\section{Sample collection of atopic eczema patients treated with coal tar based ointments}

Three male and seven female diagnosed atopic eczema patients (age $34 \pm 5 \mathrm{yr}$, range: 18-52 yr.) were treated with coal tar ointments for $21 \pm 9$ days (range: 7-33 days), which covered $20-86 \%$ of their body surface. Treatment started twice a day with $3 \%$ pix lithantracis in petrolatum or in $10 \%$ zinc oxide plus $90 \%$ petrolatum during the first 2-3 days. In all cases, this treatment was well-tolerated and was intensified by applying twice a day $5 \%$ pix lithantracis in petrolatum/zinc oxide-petrolatum for another 2-3 days. Subsequently, a 10\% coal tar ointment was applied until the patient was discharged from the hospital. After informed consent, punch biopsies $(4 \mathrm{~mm})$ were obtained under local anesthesia, two before treatment $(t=0)$ and two after one week of continuous application of coal tar ointments $(t=7)$ from treated areas only. One biopsy sample per individual was stored at $-20^{\circ} \mathrm{C}$ until DNA isolation. The other biopt was fixed in formalin and subsequently inbedded in paraffin. Sections of $5 \mu \mathrm{m}$ were cut and placed on coated slides. Morning urine was obtained at $\mathrm{t}=0, \mathrm{t}=1$ and $\mathrm{t}=7$ days and stored at $-20^{\circ} \mathrm{C}$ for analysis of the urinary metabolites 1-hydroxypyrene and 3-hydroxy-B[a]P. The study was approved by the medical ethical committee of the Maastricht University.

\section{Immunocytochemical staining (ICC) for BPDE-DNA and p53}

Fluorescence assays in lymphocytes: Immunocytochemical staining was performed as originally described by Stierum et al. (16). Slides were dehydrated, rinsed with distilled water and boiled for $10 \mathrm{~min}$ in $10 \mathrm{mM}$ sodium citrate $\mathrm{pH}$ 6.0. For analysis of p53 accumulation in in vitro treated lymphocytes, slides were incubated with a polyclonal antibody CM-1, raised against a full-length recombinant human p53 (Medical Sciences Institute, Dundee, Scotland, dilution 1:100 in 2\% BSA/PBS) and subsequently a biotinylated goat anti-rabbit IgG was used as secondary antibody (Vector Laboratories, Burlingame, California, USA, dilution 1:200 in 2\% BSA/PBS). After washing with PBS, slides were incubated for $30 \mathrm{~min}$ with fluorescein avidin D (1:500), washed, dehydrated and counterstained with propidium iodide. As a positive control, SV40-immortalized human bronchial epithelial cells, BEAS-2B, were used. These cells have been shown to contain detectable levels of wild-type p53. For staining of BPDE-DNA adducts, a rabbit polyclonal antibody against BPDE-DNA (F29 (17), dilution 1:100 in 2\% BSA/PBS) was used as first antibody. The following 
steps were identical to the p53 staining. 100 Randomly chosen cells were scored blindly using a Zeiss Axioskop fluorescence microscope and the level of staining was expressed as: (cells positively stained/total of scored cells) $\times 100 \%$.

Peroxidase assay in skin biopts: Slides were boiled twice in $10 \mathrm{mM}$ sodium citrate (pH 6.0) for 5 minutes. For analysis of $\mathrm{p} 53$ in the biopsy sections, a mouse monoclonal $\operatorname{lgG} 2 \mathrm{~b}$ antibody (DO7, raised against recombinant human p53, Novocastra Laboratories, Newcastle upon Tyne, UK, dilution 1:500) was used as primary antibody and a biotinylated rabbit anti-mouse antibody as secondary antibody. Immunoperoxidase staining was performed by using an $\mathrm{ABC}$ elite kit Vector [Avidin $\mathrm{DH}+$ biotinylated horse-radish peroxidase $\mathrm{H}$ ]. Visualization was achieved by using a DAB-kit for $5 \mathrm{~min}$ according to the instructions of the manufacturer (Brunschwig, Amsterdam, the Netherlands). Slides were blindly scored by two independent observers as respectively class I: cells of the basal layer of the epidermis were negative/slightly positive for p53; class II: cells of the basal layer were clearly positive; and class III: cells of the basal layer were highly positive (overall agreement of the two observers was $100 \%$ ). Additionally, p53 levels in the stratum basale of each skin section were quantitated on a continuous scale using an Image Processing and Analysis System (Quantimet 500, Leica, Cambridge, England). Firstly, the transmission/pixel was determined by dividing the measured intensity in the nuclei by that in the extranuclear area (=background). Secondly, to obtain the stain density, the absorbance was calculated for each pixel by the negative logarithm of the transmission and averaged, which is linearly related to the amount of stain in the cell. Subsequently, the stain density was multiplied by the area fraction positively stained for $\mathrm{p} 53$ (=number of pixels), as compared with the total area that was scored (stratum basale over a length of 2000-4000 $\mu \mathrm{m}$ ) to obtain the final relative stain density (in arbitrary units, a.u.). In order to evaluate inter-coupe variations, two different coupes on one slide were quantitated; both measurements appeared highly correlated $(r=0.978, p=0.0038, n=5)$. Moreover, the semi-quantitative assessment of p53 staining and the quantitative measurements were highly in agreement (class I: median staining intensity 0.01 a.u. (range $0.002-0.05$ ), class III: 0.09 a.u. (range 0.05 0.25 ) and class Iil: 0.48 a.u. (range $0.17-0.759$ ), $p=0.0001$ by the nonparametric Kruskal-Wallis test). Unfortunately, we were not successful in ICC-staining of skin biopsy samples for PAH-related DNA adducts.

\section{DNA isolation and ${ }^{32}$ P-postlabeling}

DNA of lymphocytes was isolated using a simple salting-out procedure as described by Miller et al. (18), with a small modification by applying one additional extraction with chloroform:isoamylalcohol (24:1). DNA of biopsy samples was isolated using a phenol extraction method. ${ }^{32}$ P-postlabeling analysis of all samples was performed as described earlier (19). After digestion of $10 \mu \mathrm{g}$ DNA with micrococcal endonuclease $\left(0.4\right.$ units) and spleen phosphodiesterase $(2.8 \mu \mathrm{g})$ for $3 \mathrm{~h}$ at $37^{\circ} \mathrm{C}$, the digest was treated with nuclease P1 $(6.3 \mu \mathrm{g})$ for $40 \mathrm{~min}$. Labeling was carried out with excess of $\left[\gamma^{32} \mathrm{P}\right]-\mathrm{ATP}$ and 5 Units of T4 polynucleotide kinase. Adducts were resolved on poly(ethylenimine)-cellulose TLC sheets (Merck, Germany) using the following solvents: D1, $1 \mathrm{M} \mathrm{NaH}_{2} \mathrm{PO}_{4}$ pH 6.5; D2, $8.5 \mathrm{M}$ urea, $5.3 \mathrm{M}$ lithium formate $\mathrm{pH}$ 3.5; 
D3, 1.2 M lithium chloride, 0.5 M Tris, $8.5 \mathrm{M}$ urea pH 8.0; D4, $1.7 \mathrm{M} \mathrm{NaH}_{2} \mathrm{PO}_{4} \mathrm{pH}$ 6.0. In each experiment, 3 standards of $\left[{ }^{3} \mathrm{H}\right] \mathrm{BPDE}$ modified DNA with known modification levels ( 1 per $10^{7}, 10^{8}, 10^{9}$ nucleotides) were run in parallel for quantification purposes. Quantification was performed by using phosphor-imaging technology (Molecular Dynamics ${ }^{\mathrm{TM}}$, Sunnyvale, CA, USA). A detection limit for BPDE-DNA adducts of $<0.1$ adducts per $10^{8}$ nucleotides was reached. Inter-assay variation was $<20 \%$.

\section{GSTM1 genotyping}

The GSTM1 genotype was determined using a polymerase chain reaction (PCR)based assay as described by Brockmöller et al. (20). PCR was carried out in a total volume of $50 \mu \mathrm{l}$, containing $0.2 \mu \mathrm{g}$ DNA, $0.2 \mathrm{mM}$ of each dNTP, and $25 \mu \mathrm{l}$ PCR buffer containing $15 \mathrm{mM} \mathrm{MgCl}$. Exact information about the primers used can be found in Brockmöller et all. (20). After denaturation at $94^{\circ} \mathrm{C}$ for $4 \mathrm{~min}, 1.25 \mathrm{U}$ of Taqpolymerase (Pharmacia Biotech, Roosendaal, The Netherlands) was added, followed by 35 cycles of amplification. An aliquot of $10 \mu \mathrm{l}$ of the PCR product was analyzed on a $3 \%$ agarose gel for the presence of bands at $338 \mathrm{bp}$ (control) and $273 \mathrm{bp}$ (GSTM1).

\section{1-Hydroxypyrene and 3-hydroxy-B[a]P in urine of treated patients}

Detection of 1-hydroxypyrene and 3-hydoxy-B[a]P in urine was performed as described by Jongeneelen et al. (21). The method consisted of enzymatic hydrolysis with B-glucuronidase and arylsulphatase, solid phase extraction on a Sep-pak C-1B cartridge and elution with methanol. Reversed phase HPLC (Kratos solvent delivery system; Column: Hypersil 5 ODS) and fluorescence detection (Perkin-Elmer LS-30) were employed, using excitation and emission wavelengths of $253 \mathrm{~nm}$ and $423 \mathrm{~nm}$ for 3-hydroxy-B[a]P and respectively $232 \mathrm{~nm}$ and $384 \mathrm{~nm}$ for 1-hydroxypyrene. Peak area was used for quantification. Concentrations were corrected for creatinine excretion, which was measured using a diagnostic kit of Sigma (no. 555-A). The detection limit was $200 \mathrm{ng}$ 3-hydroxy-B[a]P and $80 \mathrm{ng}$ 1-hydroxypyrene per liter urine, using a signal / background ratio of 3. Day-to-day variation and intra-assay variation were respectively $14 \%$ and $6 \%$.

\section{Statistics}

Results are presented as median and range. Spearman rank correlation coefficients were applied to assess correlations between several parameters or measurements. The nonparametric Mann-Whitney U-test (2 groups) and the Kruskal-Wallis test ( 3 groups) were applied to determine statistical differences. Furthermore, multiple regression was applied to assess the combined effects of GSTM1 and aromatic-DNA adduct levels on $\mathrm{p} 53$ accumulation. $\mathrm{P}<0.05$ was considered significant. 


\section{Results}

\section{In vitro treated lymphocytes}

In phytoheamagglutinine stimulated lymphocytes that were incubated with 2.5 $\mu \mathrm{M}$ BPDE for 18 hours, BPDE-DNA adduct levels determined by ICC were significantly increased as compared to nonexposed controls; median $40 \%$ (range 5$86 \%, \mathrm{n}=44$ ) of the cells were positively stained in BPDE exposed cells vs. $1 \%$ (range $0-28 \%, \mathrm{n}=11)$ in controls $(\mathrm{P}<0.001)$. In BPDE treated cells, the median DNA adduct level assessed by ${ }^{32} \mathrm{P}$-postlabeling was 583.3 adducts per $10^{7}$ nucleotides and ranged from 23.2 to 1706.0 (percentage of variance: $86 \%$ ). Parallel adduct analyses by means of ${ }^{32} \mathrm{P}$-postlabeling and ICC in a subgroup of 22 individuals were highly correlated in in vitro treated lymphocytes $\left(\mathrm{r}_{\mathrm{s}}=0.73 ; \mathrm{P}<0.01\right)$. The percentage of p53 positively stained cells was $58 \%$ (range $17-89 \%$ ) in treated cells and $14 \%$ (range $3-40 \%, \mathrm{P}<0.001$ ) in controls. As shown in Figure 1, p53 positivity was correlated with BPDE-DNA. adduct levels as determined by ICC $\left(\mathrm{r}_{\mathrm{s}}=0.66, \mathrm{P}<0.001, \mathrm{n}=44\right)$. The same holds true for p53 positivity and adduct levels determined by ${ }^{32} \mathrm{P}$-postlabeling $\left(\mathrm{r}_{\mathrm{s}}=0.56, \mathrm{P}<0.001\right)$.

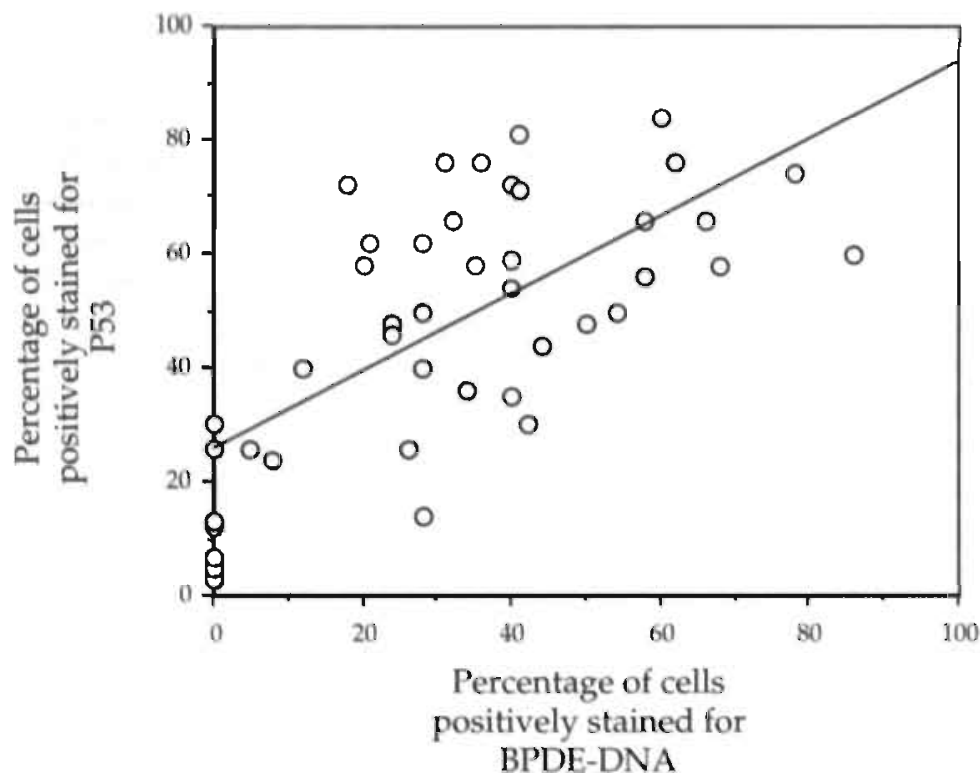

Figure 1. Relationship between BPDE-DNA adducts and p53 expression in cultured peripheral blood lymphocytes exposed in vitro to BPDE, assessed by immunocytochemistry and expressed as percentage of cells positively stained.

To determine whether p53 accumulation is influenced by GSTM1, additional analysis by multiple regression was performed and the final results showed that p53 levels were related to both BPDE-DNA adduct levels. $(\mathrm{P}=0.018)$ and the GSTM1 genotype $(\mathrm{P}=0.046)$. After adjustment for BPDE-DNA adduct levels, it was found that 
individuals lacking the GSTM1 gene had significantly higher levels of p53 (median $51 \%$, range $25-67 \%$ ) as compared with individuals which were GSTM1(+) (median $36 \%$, range $24-49 \%, P=0.0031$ ). The GSTM1 genotype did not influence BPDE-DNA adduct levels.

\section{Skin Biopts; detection of p53 and DNA adducts in relation to GSTM1}

Coal tar treatment resulted in a significant increase of median aromatic-DNA adduct levels in skin biopsy samples from 2.9 adducts per $10^{8}$ nucleotides (range: 0.710.0) before treatment, to 63.3 adducts per $10^{8}$ nucleotides (range: 10.9-276.2) as determined by ${ }^{32} \mathrm{P}$-postlabeling (19). P53 was increased in the epidermis of $7 / 10$ individuals topically treated with coal tar (Figure 2).

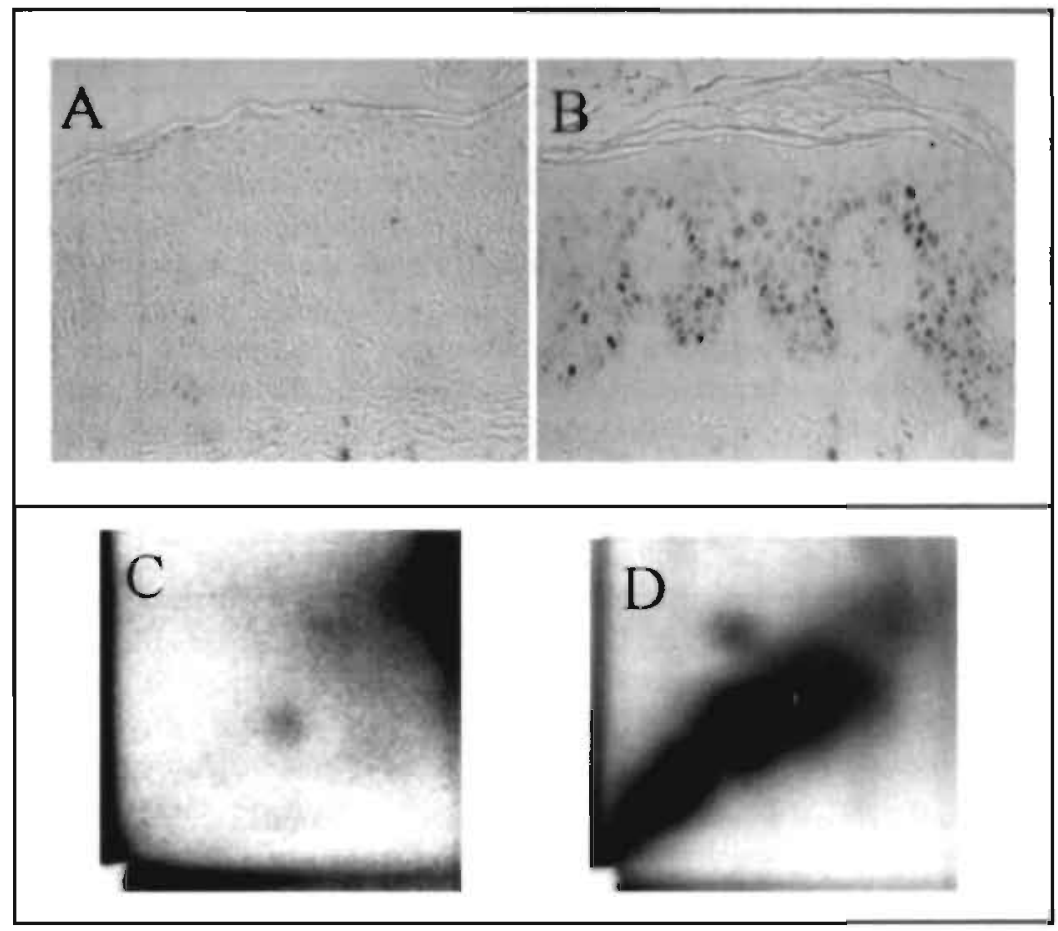

Figure 2. P53 immunocytochemistry using DO-7 antibody in human skin before (A) and after (B), treatment with coal-tar ointments for one week. Panel C and D represent the corresponding ${ }^{32} \mathrm{P}$ postlabeling profiles.

Median stain densities before and after treatment with coal-tar ointment were respectively 0.007 a.u. (range: $0.002-0.249$ ) and 0.129 a.u. (range: $0.003-0.759$ ) $(P=0.049)$. Biopsy-samples of untreated and treated skin $(n=20)$ were classified as I, II or III for p53 (see Materials and Methods section), and corresponding median DNA adduct levels were 3.6 adducts per $10^{8}$ nucleotides (range 0.6-51.6, $\mathrm{n}=11$ ), 91.1 adducts per $10^{8}$ nucleotides (range $1.0-192.8, \mathrm{n}=5$ ) and 126.5 adducts per $10^{8}$ 
nucleotides (range 11.2-276.2, $\mathrm{n}=4, \mathrm{P}=0.010$ ), respectively. Moreover, quantitative assessment of p53-stain density was significantly correlated with aromatic-DNA adduct levels $\left(\mathrm{r}_{\mathrm{s}}=0.50, \mathrm{p}=0.029, \mathrm{n}=20\right.$, Figure 3$)$. In treated skin, aromatic DNA adduct levels were higher in GSTM1(-/-) individuals (median: 192.8, range 13.6276.2, $\mathrm{n}=5$ ) as compared with GSTM1(+) individuals (median: 49, range 10.9-106.7, $\mathrm{n}=5$ ). However, due to large interindividual variations and the low amount of individuals, this difference did not reach statistical significance. A clear effect of the GSTM1 genotype on p53 accumulation was observed; the basal layer of GSTM1(-/-) individuals $(n=5)$ contained high levels of p53 (median: 0.47 a.u., range $0.08-0.76$ ). Whereas, skin of GSTM1(+) patients $(n=5)$ contained only low levels of $p 53$ (median: 0.05 a.u., range $0.003-0.18)(\mathrm{P}=0.026)$. Similar results were obtained by the semiquantitative approach.

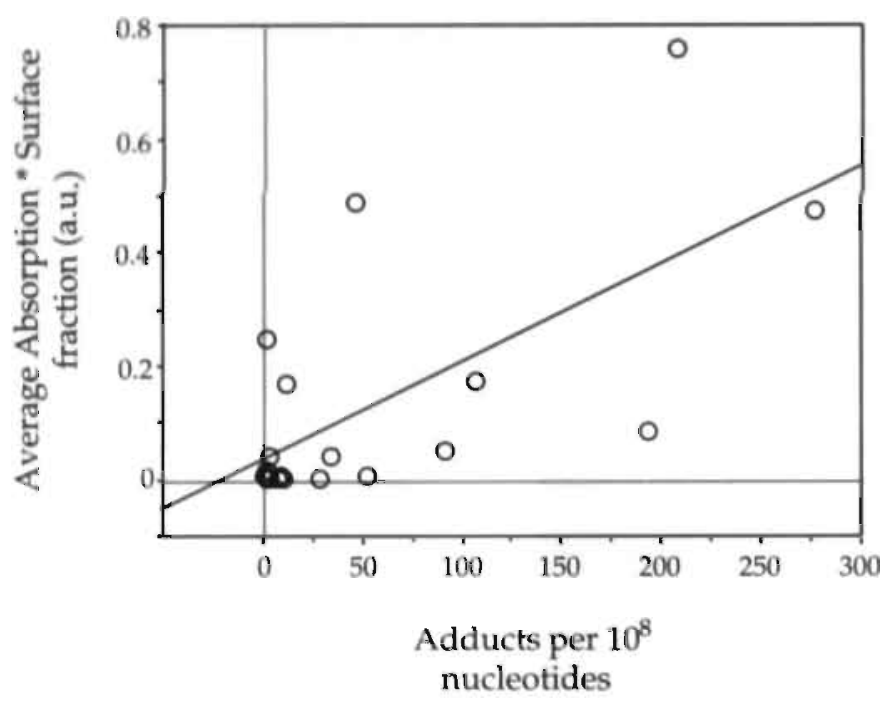

Figure 3. Relationship between aromatic-DNA adduct levels in human skin with or without coal-tar treatment (adducts per $10^{8}$ nucleotides) and p53 levels in the stratum basale of the epidermis as assessed by quantitative immunocytochemistry $\left(r_{\mathrm{S}}=0.502, P=0.029, \mathrm{n}=20\right)$.

Influence of GSTM1 on urinary excretion profiles in coal tar treated patients

Median baseline urinary excretion levels of 1-hydroxypyrene and 3-hydroxyB[a]P were respectively $0.39 \mu \mathrm{mol} / \mathrm{mol}$ creatinine (range: $0.12-1.57$ ) and 0.01 $\mu \mathrm{mol} / \mathrm{mol}$ creatinine (range: $<0.01-0.04$ ), respectively. Urinary excretion of 1 hydroxypyrene and 3-hydroxy-B[a]P was increased to $139.7 \mu \mathrm{mol} / \mathrm{mol}$ creatinine (median, range: $26.0-510.5$ ) and $1.18 \mu \mathrm{mol} / \mathrm{mol}$ creatinine (median, range: $<0.01-2.14$ ) respectively, after 1 week of continuous application of coal tar ointments (19). Interestingly, after 1 week of treatment, GSTM1(-/-) individuals had significantly lower urinary concentrations of 1-hydroxypyrene (median: $70.4 \mu \mathrm{mol} / \mathrm{mol}$ creatinine, range 26.0-162.2) as compared with GSTM1(+) subjects (median: 205.7 
range 127.9-510.5, $\mathrm{P}=0.042$ ). On the other hand, the median excretion of 3-hydroxy$\mathrm{B}[\mathrm{a}] \mathrm{P}$ was not significantly different between subjects with different genotypes. Median levels were $1.32 \mu \mathrm{mol}$ 3-hydroxy-B[a]P/mol creatinine (range 0.04-2.14) and $0.64 \mu \mathrm{mol}$ 3-hydroxy-B[a]P/mol creatinine (range: <detectionlimit- 1.52) for respectively GSTM1(-/-) and GSTM1(+) patients.

\section{Discussion}

In the present study, the relationship between aromatic-DNA adduct formation and subsequent accumulation of p53 was examined in lymphocytes of healthy volunteers in vitro incubated with BPDE, and in vioo in skin of eczema patients topically treated with coal tar ointments. It was found that in both cases the levels of DNA adducts and p53 accumulation were significantly increased and correlated, and that the GSTM1 genotype seemed to influence this relationship, with GSTMI (-/-) individuals having the highest levels of p53.

The results of the in vitro study indicate that aromatic-DNA adduct formation may result in an accumulation of p53, which may provide additional time for effective DNA repair or may direct heavily damaged cells into apoptosis. However, this correlation is not necessarily causal, since other mechanisms, related to BPDEexposure, may also result in accumulation of putatively wild type p53 and it is possible that the level of aromatic-DNA adducts merely coincides. For example, single strand breaks may initiate the accumulation of p53 (22) and it has also been shown that certain carcinogenic agents may induce a change in the conformation of the p53 protein from the wild-type to a mutant phenotype (23). Similarly, BPDE may interact with the p53 protein and may so prolong its half-life. Additionally, we observed an effect of GSTM1 on p53 accumulation. Rämet et al. (24) demonstrated that in carcinoma cell-lines, metabolism of B[a]P to diolepoxides is necessary for p53 accumulation to occur. GSTM1, which is known to catalyze the reaction of glutathione with BPDE, may decrease the levels of diolepoxides and as a consequence p53 expression is less increased as compared with individuals lacking GSTM1-1 activity. Such an effect might explain our results regarding p53 accumulation. No effect of GSTM1 was observed on BPDE-DNA adduct formation. This could be explained by p53 induced DNA repair (nucleotide excision repair); incubations were performed over a period of 18 hours and p53 mediated enhancement of DNA repair may reduce DNA adduct levels during this incubation period. Previously, it was found that most of the BPDE-DNA adducts are removed during the first 24 hours after exposure (25). Furthermore, p53 mediated cell-death of highly damaged cells would result in decreased DNA adduct levels.

In normal unexposed skin, p53 is short-lived and therefore it is usually undetectable by ICC. However, in one individual of our in vivo study, p53 was readily detectable in untreated skin. Since we started this study in the summer, an influence of UV-irradiation cannot be excluded. Short-term UV-radiation has been found to increase p53 expression in normal skin (26). After 1 week of treatment with coal tar ointments without further exposure to UV, p53 was detectable in most skin 
samples and was increased as compared to the pretreatment measurement in 7 out of 10 individuals. Aromatic-DNA adduct levels were significantly correlated with p53 levels. Similarly, Wolterbeek et al. (27) found a relationship between B[a]P-DNA adducts and p53 accumulation in tracheal epithelium of hamsters. Furthermore, Bjelogrlic et al. (28) observed an increase of p53 in mouse skin after treatment with BPDE and P53 expression coincided with BPDE-DNA adduct levels. However, the mean adduct level in skin of p53-positive mice did not significantly differ from that in p53-negative mice. Although in the present study a significant relationship was observed between aromatic-DNA adducts and accompanying p53 levels in the same skin sample, large interindividual variation was present (Figure 3), indicating that aromatic-DNA adducts are probably not predominant for p53 accumulation in skin cells.

As in the in vitro experiment with lymphocytes, an influence of the GSTM1 genotype was observed; the epidermis of GSTM1(-/-) individuals showed higher levels of p53 in the stratum basale as compared to GSTM1(+) subjects. Although the major GST isoenzyme in human skin seems to be of the Pi-class, GST's of the Muclass are present in relatively low concentrations (13). It has been shown that GST of the Mu-class is present in cells of the stratum basale of normal human epidermis (14). The enhanced levels of p53 in the basal layer in skin of GSTM1(-/-) individuals may imply that p53 mediated cellular responses in human skin are directly related to GSTM1-1 activities after PAH exposure.

We found no statistically significant relationship between the GSTM1 genotype and aromatic DNA adduct levels in coal-tar treated skin. Also in bronchial tissue of smokers, Schoket et al. (29) recently observed no such correlation, which is contrary to previous studies $(10,12,30)$. In peripheral blood cells of smokers, significantly different adduct levels determined by 32P-postlabeling in white blood cells of GSTM1(-/-) and GSTM1(+) individuals were found (30), also in combination with other polymorphic genotypes, like CYP1A1 (31) or NAT2 (32). Thus, the exact influence of the GSTM1 polymorphism on PAH metabolism and adduct formation is still not completely elucidated. The results of the present study suggest that p53 mediated induction of DNA repair might reduce aromatic-DNA adduct levels, especially in GSTM1(-/-) individuals.

In the present study, an effect of GSTM1 on PAH metabolism is evident from the urinary analysis of 1-hydroxypyrene, although this effect was not observed regarding urinary 3-hydroxy-B[a]P levels. Alexandrie et al. (33) also observed an effect of GSTM1 on urinary 1-hydroxypyrene levels in an occupational setting. However, their study showed opposite results; GSTM1(-/-) subjects excreted higher levels of 1-hydroxypyrene as compared to GSTM1(+) subjects. At this moment, no explanation can be given for these discrepancies.

Overall, it can be concluded that GSTM1 and p53 accumulation may act in concert as a protective mechanism against PAH induced DNA damage in human cells. The results of the present study indicate that further research is necessary to further elucidate the complex network of protective reactions after genotoxic assaults. 


\section{References}

1. Hall, M., Grover, P.L. (1990) Polycyclic aromatic hydrocarbons: metabolism, activation, tumor-initiation. In: Cooper, C.S., Grover, P.L. (eds) Chemical Carcinogenesis and Mutagenesis. Vol 1. New York: Raven Press, pp 327-72.

2. Nakayama, J., Yuspa, S.H., Poirier, M.C. (1984) Benzo[a]pyrene-DNA adduct formation and removal in mouse epidermis in vivo and in vitro: relationship of DNA binding to initiation of skin carcinogenesis. Cancer Res., 44, 4087-4095.

3. Alworth, W.L., Viaje, A., Sandoval, A., Warren, B.S., Slaga, T.J. (1991) Potent inhibitory effects of suicide inhibitors of P450 isozymes on 7,12-dimethylbenzla]anthracene and benzo[a]pyrene initiated skin tumors. Carcinogenesis, 12, 1209-1215.

4. Huang, M-T., Wang, Z.Y., Georgiadis, C.A., Laskin, J.D., Conney, A.H. (1992) Inhibitory effects of curcumin on tumor initiation by benzo[a]pyrene and 7,12. dimethylbenz[a]anthracene. Carcinogenesis, 13, 2183-2186.

5. Lane, D.P. (1992) P53, guardian of the genome. Nature, 358, 15-16.

6 El-Deiry, W.S., Harper, J.W., O'Conner, P.M., Velculecu, V.E., Canman, C.E., Jackman, J., et al. (1994) WAF1/CIP1 is induced in p53-mediated G1 arrest and apoptosis. Cancer Res $54,1169-1174$.

7. Yonish-Rouach, E., Grunwald, D., Wilder, S., Kimchi, A., May, E., Lawrence, J.J., et al. (1993) P53-mediated cell death: relationship to cell cycle control. Mol. Cell Biol. 13, 1415-1423.

8. Li, F.P., Fraumeni, J.F., Mulvihill, J.J., Blattner, W.A., Dreyfus, M.G., Tucker, M.A., Miller, R.M. (1988) A cancer family syndrome in twent-four kindreds. Cancer Res., 48, 5358-5362.

9. Donehower, L.A., Harvey, M., Slagle, B.L., McArthur, M.J., Montgomery, C.A., Butel, J.S., Bradley, A. (1992) Mice deficient for p53 are developmentally normal but susceptible to spontaneous tumours. Nature, 356, 215-221.

10 Ketterer, B., Harris, J.M., Talaska, G., Meyer, D.J., Pemble, S.E., Taylor, J.B., et al. (1992) The human glutathione S-transferase supergene family, its polymorphism, and its effects on susceptibility to lung cancer. Environ. Health Perspect., 98, 87-94.

11. Ketterer, B., Meyer, D.J., Clark, A.G. Soluble glutathione transferase isozymes. In: Sies, H., Ketterer, B. (eds). Glutathione conjugation. London: Academic Press: 73-135.

12. Kato, S, Bowman, E.D., Harrington, A.M., Blomeke, B., Shields, P.G. (1995) Human lung carcinogen-DNA adduct levels mediated by genetic polymorphisms in vivo. I. Nat. Cancer Inst., 87, 902-907.

13. Raza, H., Awasthi, Y.C., Zaim, M.T., Eckert, R.L., Mukhtar, H. (1991) Glutathione Stransferases in human and rodent skin: multiple forms and species specific expression. I. Invest. Dermatol., 96, 463-467.

14. Moral, A., Palou, J., Lafuente, A., Molina, R., Piulachs, J., Castel, T., et al. (1997) Immunohistochemical study of alpha, mu, pi class glutathione $\mathrm{S}$ transferase expression in malignant melanoma. MMM group. Multiple Malignant Melanoma group. $\mathrm{Br}$. I. Dermatol., 136, 345-350.

15. BØyum, A. (1976) Isolation of lymphocytes, granulocytes and macrophages. Scand. L Immunol., 5, 9-15.

16. Stierum, R., Van Herwijnen, M.H.M., Pasman, P.C., Hageman, G.J., Kleinjans, J.C.S., Van Agen, B. (1995) Inhibition of poly(ADP-ribose)polymerase increases $( \pm)$-antibenzo[a]pyrene diolepoxide-induced micronuclei formation and p53 accumulation in isolated human peripheral blood lymphocytes. Carcinogenesis, 16, 2765-2771.

17. Van Schooten, F.J., Kriek, E., Steenwinkel, M.J.S.T., Noteborn, H.P.J.M., Hillebrand, M.J.X., Van Leeuwen, F.E. (1987) The binding efficiency of polyclonal and monoclonal antibodies to DNA modified with benzo[a]pyrene diol epoxide is dependent on the level of modification. Implications for quantitation of benzo[a]pyrene-DNA adducts in vivo. Carcinogenesis, 8, 1263-1269.

18. Miller, S.A., Dykes, D.D., Polesky, H.F. (1988) A simple salting out procedure for extracting DNA from human nucleated cells. Nucleic Acid Res. 16, 1215. 
19. Godschalk, R.W.L., Ostertag, J.U., Moonen, E.J.C., Neumann, H.A.M., Kleinjans, J.C.S., Van Schooten, F.J. (1998) Aromatic DNA adducts in human white blood cells and skin after dermal application of coal tar. Cancer Epidemiol. Biomarkers \& Prev., 7, 767-773.

20 Brockmöller, J., Gross, D., Kerb, R., Drakoulis, N., Roots, I. (1992) Correlation between trans-stilbene oxide glutathione conjugation activity and the deletion mutation in the glutathione S-transferase class Mui gene detected by polymerase chain reaction. Biochem. Pharmacol., 43, 647-650.

21. Jongeneelen, F.J., Bos, R.P., Anzion, R.B.M., Theeuws, J.L.G., Henderson, P.T. (1986) Biological monitoring of polycyclic aromatic hydrocarbons in urine. Scand. I. Work Environ. Health, 12, 137-143.

22. Nelson, W., Kastan, M. (1994) DNA strand breaks: the DNA template alterations that trigger p53-dependent DNA damage response pathways. Mol. Cell. Biol. 14, 18151823.

23. Hainaut, P., Milner, J. (1993) Redox of p53 conformation and sequence specific DNA binding in vitro. Cancer Res, 53, 4469-4473.

24. Rämet, M., Castrén, K., Järvinen, K., Pekkala, K., Turpeenniemi-Hujanen, T., Soini, Y., et al. (1995) P53 protein expression is correlated with benzo[a]pyrene-DNA adducts in carcinoma cell lines. Carcinogenesis, 16, 2117-2124.

25. Stierum, R.H., Van Herwijnen, M.H.M., Maas, L.M., Hageman, G.J., Kleinjans, J.C.S. (1994) Measurement by ${ }^{32} \mathrm{P}$-postlabeling of $( \pm)$-anti-benzo[a]pyrene diolepoxide- $\mathrm{N}^{2}$ deoxyguanosine adduct persistence in unstimulated human peripheral blood lymphocytes. Mut. Res, 325, 31-37.

26. Hall, P.A., McKee, P.H., Menage, H.P., Dover, R., Lane, D.P. (1993) High levels of p53 protein in UV-irradiated normal human skin. Oncogene, 8, 203-207.

27. Wolterbeek, A.P.M., Roggeband, R., Baan, R.A., Feron, V.J., Rutten, A.A.J.J.L. (1995), Relation between benzo[a]pyrene-DNA adducts, cell proliferation and p53 expression in tracheal epithelium of hamsters fed a high B-carotene diet. Carcinogenesis, 16, 1617 1622.

28. Bjelogrlic, N.M., Mäkinen, M., Stenbäck, F., Vähäkangas, K. (1994) Benzo[a]pyrene-7,8diol-9,10-epoxide-DNA adducts and increased p53 protein in mouse skin. Carcinogenesis, 15, 771-774.

29. Schoket, B., Phillips, D.H., Kostic, S., Vince, I. (1998) Smoking associated bulky DNA. adducts in bronchial tissue related to CYP1A1 MspI and GSTM1 genotypes in lung cancer patients. Carcinogenesis, 19, 841-846.

30. Rojas, M., Alexandrov, K., Cascorbi, I., Brockmöller, J., Likhachev, A., Pozharisski, K., et al. (1998) High benzolalpyrene diol-epoxide DNA adduct levels in lung and blood cells from individuals with combined CYP1A1 MspI/MspI-GSTM1*0/ ${ }^{*} 0$ genotypes. Pharmacogenetics, 8, 109-118.

31. Ichiba, M., Hagmar, L., Rannung, A., Högstedt, B., Alexandrie, A., Carstensen, U., et al. (1994) Aromatic DNA aciducts, micronuclei and genetic polymorphism for CYP1A1 and GST 1 in chimney sweeps. Carcinogenesis, 15, 1347-1352.

32. Hou, S-M., Lambert, B., Hemminki, K. (1995) Relationship between hprt mutant frequency, aromatic DNA adducts and genotypes for GSTM1 and NAT2 in bus maintenance workers. Carcinogenesis, 16, 1913-1917.

33. Alexandrie, A.., Carstensen, U., Eriksson, A., Levin, J., Östman, C., Nilsson, T., et al. Urinary 1-hydroxypyrene in relation to $\mathrm{PAH}$-exposure and genetic polymorphisms in. aluminium smelter workers. Abstract book of meeting: DNA adducts and mutations in human biomonitoring, Stockholm, Sweden, June 9-13, 1996. 


\title{
Chapter 91
}

\section{Repair of oxidative DNA damage after acute oral exposure to benzo[a]pyrene}

\author{
R.W.L. Godschalk, P.A.E.L. Schilderman, E. van Agen, W.M.R. Broekmans, \\ F.J. van Schooten, J.C.S. Kleinjans
}

Department of Health Risk Analysis and Toxicology,

University of Maastricht, Maastricht, The Netherlands

Submitted to Cancer Research

\begin{abstract}
Reactive oxygen species (ROS), produced during the metabolic conversion of benzo[a]pyrene $(\mathrm{B}[\mathrm{a}] \mathrm{P})$ to its reactive derivatives, may be involved in $\mathrm{B}[\mathrm{a} \mid \mathrm{P}$ induced carcinogenesis. Therefore, we studied the formation of 7-hydro-8-oxo-2:deoxyguanosine (8-oxo-dG) in lung, liver and heart of rats after a single oral dose of $\mathrm{B}[\mathrm{a}] \mathrm{P}$ (10 $\mathrm{mg} / \mathrm{kg}$ body weight) by means of high performance liquid chromatography with electrochemical detection (HPLC-ECD). Additionally, urinary excretion of 8-oxo-dG was studied using a competitive-ELISA. In controll rats,

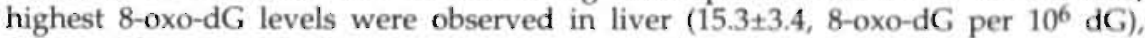
followed by respectively lung $(12.1 \pm 2.5)$ and heart $(9.3 \pm 1.0)$. The corresponding 8 oxo-dG levels in rats one day after treatment with a single oral dose of $\mathrm{B}[\mathrm{a}] \mathrm{P}$, were 8.3 \pm 3.1 per $10^{6} \mathrm{dG}$ for liver DNA. ( $\mathrm{P}=0.04$, Mann-Whitney $\mathrm{U}$-test), $9.9 \pm 1.1$ for lung DNA $(\mathrm{P}=0.12)$ and $8.8 \pm 0.9$ for heart DNA $(\mathrm{P}=0.83)$. Eleven days after exposure to $\mathrm{B}[\mathrm{a}] \mathrm{P}, 8$-oxo-dG levels further decreased in liver $(6.0 \pm 1.1, \mathrm{P}=0.004)$ and lung $(5.3 \pm 2.3$, $\mathrm{P}=0.05$ ), whereas in heart-DNA no changes in 8-oxo-dG levels were observed. Excretion of 8-oxo-dG in 24 hours urine of exposed rats, increased from day 1 (1134 $\pm 351 \mathrm{ng} 8$-oxo-dG per 24 hours) to day 21 (2030 $\pm 410 \mathrm{ng} 8$-oxo-dG per 24 hours, $\mathrm{P}=0.002$ ). In control rats, a mean excretion of $689 \pm 237 \mathrm{ng} 8$-oxo-dG/24 hours was observed. These results indicate that acute exposure to B[a]P might induce nonspecific DNA repair activities that in contrast with the hypothesis, indirectly reduce the level of oxidative DNA damage in target tissues for DNA adduct formation.
\end{abstract}

Benzo[a]pyrene (B[a]P) is, a well studied polycyclic aromatic hydrocarbon, which is known to be metabolized by cytochrome $\mathrm{P} 450$ mediated processes to certain reactive diol-epoxides that can interact with DNA (1). However, other metabolic routes have been described, which might be of importance for organs that contain relatively low levels of cytochrome P450 (e.g., lung or stomach). For instance, B[a]P can be metabolized via a one-electron oxidation pathway to a B[a]P-radical cation (2) that may covalently bind to DNA (3). Additionally, B[a]P radical-cations are thought to be precursors for the labile phenol, 6-OH-B[a]P (4). Auto-oxidation of this derivative may ultimately result in the formation of $\mathrm{B}[\mathrm{a}] \mathrm{P}$ quinones. $\mathrm{B}[\mathrm{a}] \mathrm{P}$ quinones are almost invariably found after metabolism of $\mathrm{B}[\mathrm{a}] \mathrm{P}$, sometimes accounting for more than $50 \%$ of the total metabolic yield (5). The B[a]P quinones formed are $6,12-$, 
1,6- and 3,6-B[a]P dione, which can undergo redox-cycling to their corresponding $\mathrm{B}[\mathrm{a}] \mathrm{P}$ diols coupled with molecular oxygen to form superoxide and hydroxyl radicals by the Haber-Weiss and Fenton reactions (Figure 1) (6).

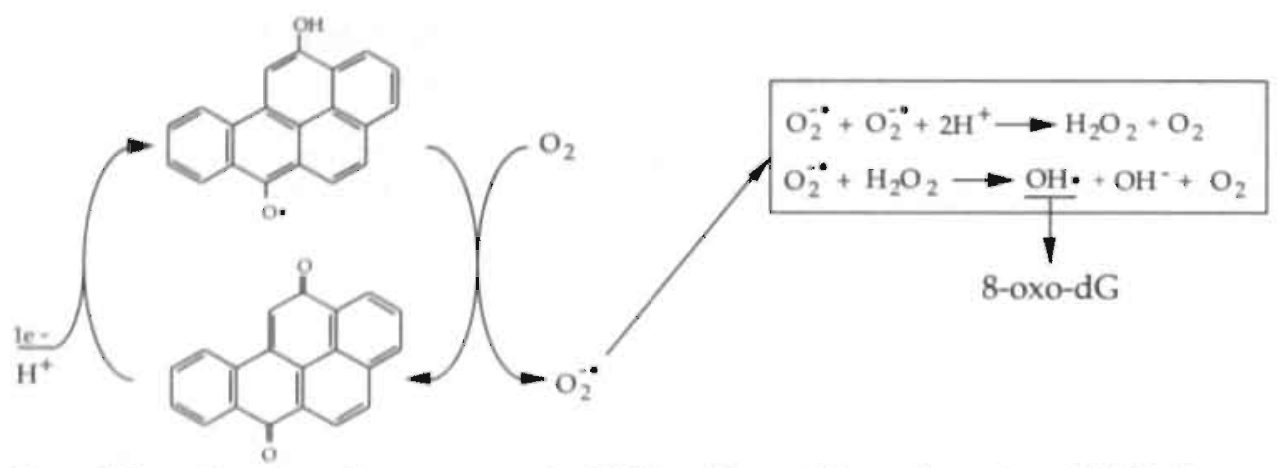

Figure 1. Formation of reactive oxygen species (ROS) and 8-oxo-dG by redox-cycling of B[a]P-diones

The reactive oxygen species (ROS) produced can give rise to oxidative DNA damage, e.g. 7-hydro-8-oxo-2'-deoxyguanosine (8-oxo-dG) formation and DNA single or double strand breakage. 8-Oxo-dG and other kinds of oxidatively damaged bases were found to be promutagenic lesions and may thereby contribute to the development of B[a]P induced cancers (7). Indeed, increased levels of oxidatively damaged bases have been observed in cells treated with B[a]P in vitro with (8) or without (9) additional exposure to light and in livers of laboratory rodents orally exposed to B[a]P (10). Thus, it is hypothesized that exposure to B[a]P generates free radicals and may result in increased levels of oxidative DNA damage.

Fifteen male Lewis rats (250-350 gram bodyweight (bw.)) were exposed to a single oral dose of B[a]P (10 mg B[a]P in tricaprylin $/ \mathrm{kg}$ bw). Rats were housed individually in metabolic cages to collect 24 hours urine samples and they were provided with food (diet no. RSM-A, Hope Farms, Woerden, The Netherlands) and water ad libitum. Rats were killed at 1, 2, 4, 11 and 21 days ( 3 rats per time-point) after the treatment to study the time-course of 8-oxo-dG formation and B[a]P-related bulky DNA adducts. Three control rats received vehiculum only (tricaprylin) and were killed one day after treatment. Liver, lung and heart were removed and frozen in $-20^{\circ} \mathrm{C}$ until DNA isolation. DNA was isolated from these tissues by a standard phenol extraction procedure and subsequently analyzed for the presence of 8-oxo-dG by means of high performance liquid chromatography with electrochemical detection (HPLC-ECD)(11). The mobile phase consisted of $10 \%$ aqueous methanol containing citric acid $(30 \mathrm{mM})$. Elution was performed at a flow rate of $1.0 \mathrm{ml} / \mathrm{min}$. The limit of detection was $40 \mathrm{fmol}$ absolute for 8-oxo-dG. 8-Oxo-dG excretion in 24 hours urine was studied using a competitive ELISA (obtained from the Japan Institute for the Control of Aging, Fukuroi City, Japan). A standard curve was used to calculate the level of 8-oxo-dG in urine samples. Analysis of each sample was performed in triplicate and the mean coefficient of variation was $4.5 \% \pm 1.8 \%$. 
Additionally, bulky DNA adducts were analyzed by nuclease P1 enriched 32Ppostlabeling combined with thin layer chromatography (12).

In control rats, 8-oxo-dG levels were $15.3 \pm 3.4,8$-oxo-dG per $10^{6} \mathrm{dG}$ in liver, $12.1 \pm 2.5$ in lung and $9.3 \pm 1.0$ in heart, one day after oral application of vehiculum only. The corresponding 8-oxo-dG levels in rats that were treated with a single oral dose of $\mathrm{B}[\mathrm{a}] \mathrm{P}$ were $8.3 \pm 3.1$ per $10^{6} \mathrm{dG}$ for liver $\mathrm{DNA}(\mathrm{P}=0.04$, Mann-Whitney U-test), $9.9 \pm 1.1$ for lung DNA $(\mathrm{P}=0.12)$ and $8.8 \pm 0.9$ for heart $\mathrm{DNA}(\mathrm{P}=0.83)$. In lung and liver, the 8-oxo-dG levels continued to decrease, and reached minimal levels at 11 days after exposure (liver: $6.0 \pm 1.1, \mathrm{P}=0.004$ and lung: $5.3 \pm 2.3, \mathrm{P}=0.05$ ). Whereas in heartDNA, no changes in 8-oxo-dG levels were observed (Table I and Figure 2).

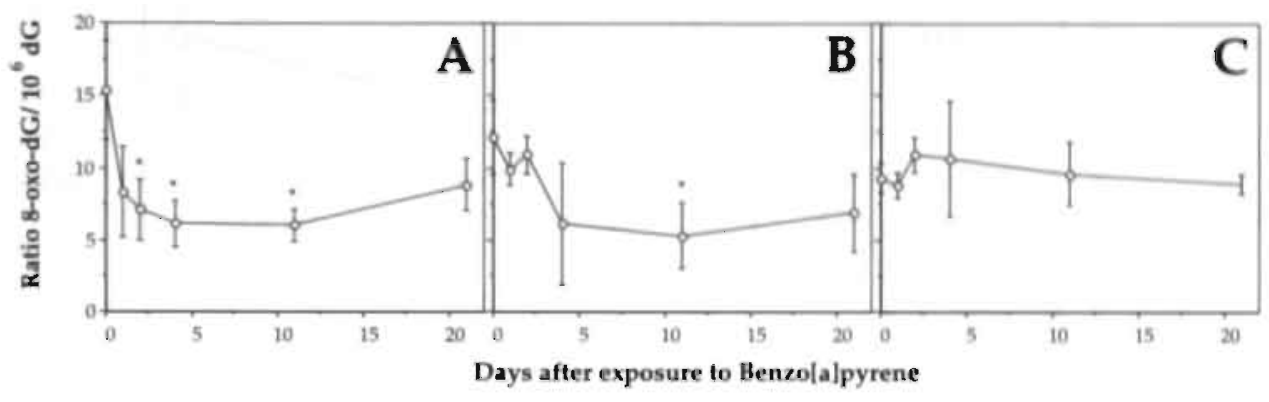

Figure 2. Levels of 8-oxo-dG (per $10^{\circ} \mathrm{dG}$ ) in rat liver (A), lung (B), and heart (C) at several time points after a single oral dose of $\mathrm{B}[\mathrm{a}] \mathrm{P}\left(10 \mathrm{mg} / \mathrm{kg}\right.$ body weight). ${ }^{*} \mathrm{P}<0.05$ as compared with controls, which are shown at $\mathrm{t}=0$.

These results seem to be in contrast with the observations of Kim and Lee (10), who reported that 8-oxo-dG levels were significantly increased in liver DNA of female Sprague-Dawley rats at 6-12 hours after exposure to $B[a] P$, and were reduced to baseline levels after 24-96 hours. However, some major differences in experimental conditions might explain the observed discrepancies. Firstly, the dose of $\mathrm{B}[\mathrm{a}] \mathrm{P}$ was 7.5 times higher in their experiment as compared with the present study, which might result in other metabolic routes and/or higher levels of ROS generation. Secondly, animals of different strains and gender have been used, which may differ in (induction of) biotransformation and DNA repair capacities upon exposure to $\mathrm{B}[\mathrm{a}] \mathrm{P}$. Indeed, differences between males and females with regard to bulky-DNA adduct formation have been reported in humans $(13,14)$ and in laboratory rodents (15). Shugart and Kao (15) observed a higher rate of B[a]P diol-epoxide DNA adduct removal from skin in male as compared with female mice, which suggests differences in non-specific DNA repair activity or inducibility. Also, 8-oxo-dG is repaired by non-specific DNA repair enzymes and is released as deoxynucleotides. In humans, higher urinary 8-oxo-dG levels were found in males than in females (16), but this may also be related to a higher metabolic rate in men with increased availability of ROS. 
Non-specific DNA repair is likely to be involved in decreasing 8-oxo-dG levels in lung and liver of rats exposed to $\mathrm{B}[\mathrm{a}] \mathrm{P}$, since higher urinary 8-oxo-dG levels were found in exposed rats ( $1135 \pm 351 \mathrm{ng} 8$-oxo-dG/24 hours) as compared with controls $(689 \pm 237)$. From day 1 to day 21 , urinary excretion of 8 -oxo-dG gradually increased from $1135 \pm 351 \mathrm{ng} 8$-oxo-dG/24 hours to $2030 \pm 410$ ( $\mathrm{P}=0.002$, Figure 3 ).

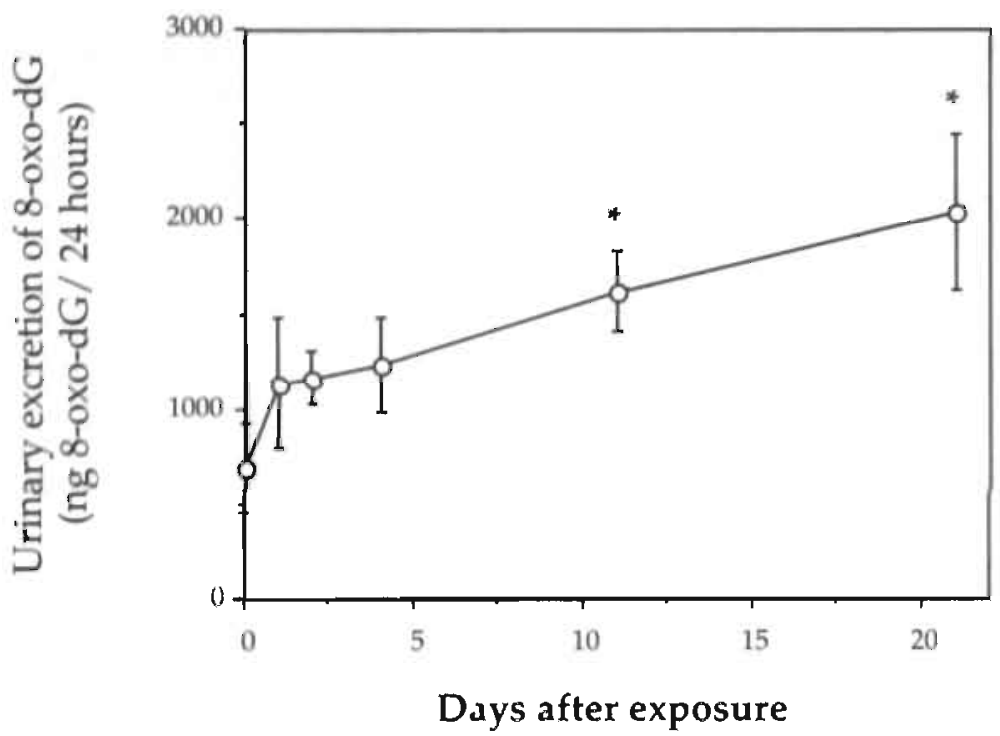

Figure 3. Total urinary excretion of 8-oxo-dG per 24 hours (ng 8-oxo-dG/ 24 hours) after acute oral exposure to $B[a] P$. * $P<0.05$ as compared with controls.

Still, it is possible that ROS and 8-oxo-dG are formed due to the metabolic conversion of B[a]P. However, an overcompensation by DNA repair ultimately results in decreased overall 8-oxo-dG levels in lung and liver, but not in heart. The observed changes in 8-oxo-dG levels are in agreement with the reported ranking order of DNA repair activities in these tissues: liver> lung> heart (17). No conclusions can be made regarding specific DNA repair glycosylases, because in that case 8-oxo-dG's will be released from the DNA as free damaged bases, 8-oxo-guanine (8-oxo-Gua) (18), which were not detected in the present experiment.

B[a]P related bulky DNA adducts at day 2 after exposure were highest in respectively heart $\left(16.5 \pm 5.1\right.$ adducts per $10^{8}$ nucleotides), lung $(6.9 \pm 2.3)$ and liver $(2.7 \pm 0.4)$ (Table I). 
Table 1. Urinary excretion of 8-oxo-dG and DNA adduct levels (bulky DNA adducts and 8-oxo-dG levels) in rat liver, lung, and heart at several time points after acute oral exposure to B[a]P.

\section{Days after BlalP exposure}

Control

1

2

4

11

21

Bulky DNA adducts a

\begin{tabular}{|c|c|c|c|c|c|c|}
\hline Liver & $<$ d.l. & $1.8 \pm 1.3$ & $2.7 \pm 0.4$ & $1.5 \pm 1.3$ & $0.5 \pm 0.4$ & $0.2 \pm 0.1$ \\
\hline Lung & $<$ d.l. & $6.3 \pm 3.7$ & $6.9 \pm 2.3$ & $5.5 \pm 1.7$ & $5.9 \pm 1.9$ & $5.0 \pm 1.5$ \\
\hline leart & $<$ d.l. & $13.4 \pm 4.9$ & $16.5 \pm 5.1$ & $14.4 \pm 5.6$ & $10.5 \pm 5.5$ & $4.0 \pm 3.0$ \\
\hline
\end{tabular}

8-Oxo-dG b

$\begin{array}{lllllll}\text { Liver } & 15.3 \pm 3.4 & 8.3 \pm 3.1 & 7.1 \pm 2.1 & 6.1 \pm 1.6 & 6.0 \pm 1.1 & 8.8 \pm 1.8 \\ \text { Lung } & 12.1 \pm 2.5 & 9.9 \pm 1.1 & 10.9 \pm 1.3 & 6.1 \pm 4.2 & 5.3 \pm 2.3 & 6.9 \pm 2.7 \\ \text { Heart } & 9.3 \pm 1.0 & 8.8 \pm 0.9 & 10.9 \pm 1.2 & 10.6 \pm 4.0 & 9.6 \pm 2.2 & 8.9 \pm 0.7\end{array}$

Urinary 8-oxo-dG $\mathrm{c}$

$\begin{array}{llllll}689 \pm & 1134 \pm & 1160 \pm & 1230 \pm & 1617 \pm & 2030 \pm \\ 237 & 351 & 143 & 246 & 217 & 410\end{array}$

a DNA adducts per $10^{8}$ nucleotides, <d.1.: below detection limit.

b amount of 8-oxo-dG per $10^{6} \mathrm{dG}$

c ng 8-oxo-dG per 24 hours

These maximal bulky-DNA adduct levels were inversely related with changes in 8oxo-dG levels in respectively liver, lung and heart. Bulky DNA. adduct levels steadily decreased from day 2 to day 21 after exposure in all three organs. Over this period, no direct link could be observed between the removal of bulky-DNA adducts and changes in 8-oxo-dG. For example in heart, B[a]P relatedl DNA adduct levels significantly decreased from day 2 to day 21 after exposure, whereas 8-oxo-dG levels did not change. Nonetheless, the removal of 8-oxo-dG from lung and liver after exposure to B[a]P, might be due to non-specific DNA repair mechanisms, primarily induced to repair bulky-DNA adducts; bulky DNA adducts are removed by NER, which aspecifically and simultaneously removes endogenously formed 8-oxo-dG. Our results indicate that acute exposure to B[a]P might induce non-specific DNA repair of DNA oxidation products. 


\section{References}

1. Hall, M., Grover, P.L. (1990) Polycyclic aromatic hydrocarbons: metabolism, activation and tumour initiation. In: Cooper, C.S., Grover, P.L. (eds) Chemical Carcinogenesis and Mutagenesis, Vol. I, pp 327-372, New York, USA, Raven Press.

2. Cavalieri, E.L., Prabhakar, D., Devanesan, D., Rogan, E.H. (1988) Radical cations in the horseradish peroxidase and prostaglandin $\mathrm{H}$ synthase mediated metabolism and binding of benzo(a)pyrene to deoxyribonucleic acid. Biochem. Pharmacol, 37, 21832187.

3. Rogan, E.H., Cavalieri, S.R., Tibbels, S.R., Cremonesi, P., Warner, C.D., Nagel, D.J., Tomer, K.B., Cerny, R.L., Gross, M.L. (1988) Synthesis and identification of benzo(a)pyrene-guanine nucleoside adducts formed by electrochemical oxidation and by horseradish peroxidase catalyzed reaction of benzo(a)pyrene with DNA. I. Am. Chem. Soc, 110: 4023-4029.

4. Cavalieri, E., Rogan, E., Cremonesi, P., and Devanesan, P.D. (1988) Radical cations as precursors in the metabolic formation of quinones from benzo(a)pyrene and 6fluorobenzo(a)pyrene. Biochem. Pharmacol. 37, 2173-2183.

5. Wang, I., Rasmussen, R., Crocker, T. (1974), Life Sci., 15, 1291.

6. Lourentzen, R.J., and Tso, P.O.P. (1977) Benzo(a)pyrenedione/ Benzo(a)pyrene diol oxidation-reduction couples and the generation of reactive reduced molecular oxygen. Biochemistry, 16, 1467-1473.

7. Halliwell, B., Gutteridge, J.M.C. (1989) The role of oxygen free radicals, ageing, and disease. In: Halliwell, B., Gutteridge, J.M.C. (eds) Free radicals in Biology and medicine, Oxford University press, pp 416-508.

8. Mauthe, R.J., Cook, V.M., Coffing, S.L., Baird, W.M. (1995) Exposure of mammalian cell cultures to benzo[a]pyrene and light in oxidative DNA damage as measured by 8hydroxyguanosine formation. Carcinogenesis, 16, 133-137.

9. Leadon, S.A., Stampfer, M.R., Bartley,J. (1988) Production of oxidative DNA damage during the metabolic activation of benzo[a]pyrene in human mammary epithelial cells correlates with cell killing. Proc. Natl. Acad. Sci. USA, 85, 4365-4368.

10. Kim, K.B., Lee, B.M. (1997) oxidative stress to DNA, protein, and antioxidant enzymes (superoxide dismutase and catalase) in rats treated with benzo[a]pyrene. Cancer Lett., $113,205-212$.

11. Schilderman, P.A.E.L., van Maanen, J.M.S., Smeets, E.J., Ten Hoor, F., Kleinjans, J.C.S. (1993) Oxygen radical formation during prostaglandin $\mathrm{H}$ synthase-mediated biotransformation of butylated hydroxyanisole. Carcinogenesis, 14, 347-353.

12. Reddy, M.V., Randerath, K. (1986) Nuclease P1 mediated enhancement of sensitivity of ${ }^{32}$ P-postlabeling test for structurally diverse DNA adducts, Carcinogenesis, 7, 15431551 .

13. Van Schooten, F.J., Godschalk, R.W.L., Breedijk, A., Maas, L.M., Kriek, E., Sakai, H., Wigbout, G., Baas, P., Van 't Veer, L., Van Zandwijk, N. (1997) "P-postlabeling of aromatic DNA adducts in white blood cells and alveolar macrophages of smokers: saturation at high exposures. Mut. Res, 378, 65-75.

14. Ryberg, D., Hewer, A., Phillips, D.H., Haugen, A. (1994) Different susceptibility to smoking induced DNA damage among male and female lung cancer patients. Cancer Res., 54, 5801-5803.

15. Shugart, L., Kao, J. (1985) examination of addduct formation in vivo in the mouse between benzo[a]pyrene and DNA of skin and hemoglobin of red blood cells. Environ. Health Perspect., 62, 223-226.

16. Loft, S., Vistisen, K., Ewertz, M., Tjonneland, A., Overvad, K., Poulsen, H.E. (1992) Oxidative DNA damage estimated by 8-hydroxydeoxyguanosine excretion in humans: influence of smoking, gender and body mass index. Carcinogenesis, 13, 2241-2247.

17. De Flora S., Izotti, A., Randerath, K., Randerath, E., Bartsch, H., Nair, J., Balansky, R., Van Schooten, F.J., Degan, P., Fronza, G., Walsh, D., Lewtas, J. (1996) DNA adducts and chronic degenerative diseases. Pathogenetic relevance and implications in preventive medicine. Mut. Res., 197-238. 
18. Shigenaga, M.K., Ames, B.N. (1991) Assays for 8-hydroxy-2'-deoxyguanosine: a biomarker of in vivo oxidative DNA damage. Free Radical Biology \& Med., 10, 211-216. 


\title{
Comparison of ${ }^{32} \mathrm{P}$-postlabeling and HPLC-FD analysis of DNA adducts in rats acutely exposed to benzo[a]pyrene
}

\author{
R.W.L. Godschalk ${ }^{1}$, I.T.M. Vermeer ${ }^{1}$, E. Kriek ${ }^{2}$, B. Floot ${ }^{2}$, P.A.E.L. Schilderman ${ }^{1}$, \\ E.J.C. Moonen ${ }^{1}$, J.C.S. Kleinjans ${ }^{1}$, F.J. van Schooten ${ }^{1}$ \\ 1Department of Health Risk Analysis and Toxicology, \\ University of Maastricht, Maastricht, The Netherlands \\ 2 Division of Molecular Carcinogenesis \\ The Netherlands Cancer Institute, Amsterdam, The Netherlands
}

Chemico-Biological Interactions, vol. 104 pp 41-54, 1997

\begin{abstract}
DNA adduct analysis is often used for biomonitoring individuals exposed to polycyclic aromatic hydrocarbons ( $\mathrm{PAH}$ ). The ${ }^{32} \mathrm{P}$-postlabeling assay is routinely applied to study the formation of aromatic bulky adducts, but cannot positively identify individual adduct types. Recently, an HPLC assay with fluorescence detection (HPLC-FD) was developed which was sufficiently sensitive to detect adducts formed by benzo[a]pyrene (B[a]P) diolepoxide isomers [( \pm )anti- and $( \pm)$ synBPDE] in occupationally exposed subjects (Rojas et al., Carcinogenesis, 16 (1995) 1373-1376). In this study, we compared both techniques using DNA samples of rats which were treated i.p. with B[a]P $(10 \mathrm{mg} / \mathrm{kg} \mathrm{bw})$. The internal dose was assessed by measuring 3-OH-B $[$ a]P excretion in urine. The detection limit of the HPLC-FD assay varied from 0.5 to 7.4 adducts per $10^{8}$ nucleotides, while the detection limit of the ${ }^{32} \mathrm{P}$-postlabeling assay was around 1 adduct per $10^{9}$ nucleotides. HPLC-FD analysis showed that BPDE-DNA adduct levels were highest in respectively heart, lung and liver. The most predominant $\mathrm{B}[\mathrm{a}] \mathrm{P}$-tetrol was the $\mathrm{I}-1$ isomer, which derives from hydrolysis of the major reaction product of DNA and (+)-anti-BPDE. ${ }^{32} \mathrm{P}$ postlabeling analysis revealed an adduct spot that comigrated with a [ $\left.{ }^{3} \mathrm{H}\right] \mathrm{BPDE}-$ DNA standard. The putative BPDE-DNA adduct levels were highest in heart followed by lung and liver and correlated significantly with tetrol I-1 levels determined by HPLC-FD ( $r=0.72, P=0.006)$. In samples in which both tetrol $\mathrm{I}-1$ and II- 2 were detected by means of HPLC-FD, this correlation was even better ( $r=0.95$, $\mathrm{P}=0.011$ ). Estimated half-lives of BPDE-DNA adducts were in the ranking order heart, lung and liver for both techniques. By ${ }^{32} \mathrm{P}$-postlabeling also other adducts than BPDE-DNA were found, resulting in highest total DNA adduct levels in respectively liver, heart and lung. Furthermore, mean $24 \mathrm{hr}$ urinary excretion of 3-OH-B[a]P was related to BPDE-DNA adduct levels in lung, liver and heart. The $32 \mathrm{P}$-postlabeling assay is sensitive and capable of detecting exposures to complex mixtures, whereas the HPLC.FD assay can be used to identify BPDE-isomers and might therefore be of value in risk assessment of individuals exposed to $\mathrm{PAH}$.
\end{abstract}




\section{Introduction}

Polycyclic aromatic hydrocarbons (PAH) are ubiquitous environmental pollutants and uptake of PAH is thought to be involved in the induction of cancer. Monitoring the concentration of PAH in the ambient air or in urine will represent the external and internal dose respectively, but will not represent the dose that eventually affects target sites. Ultimate reactive metabolites may react with DNA, giving rise to DNA adducts (1). Upon cellular replication PAH-DNA adducts, if not recognized and removed by DNA-repair, may result in structural changes of the genetic code (2). Therefore, DNA adduct analysis yields relevant information to evaluate the effective carcinogen exposure of tissues and cells and would provide a means for identifying groups or individuals at high risk. However, experiments with laboratory rodents show that PAH-DNA adduct formation and tumor induction is not always quantitatively interrelated: similar adduct levels are formed in susceptible and resistant species, strains or tissues (1). Differences in adduct stability may be involved and additionally not all adducts may have equal significance in terms of risk of gene mutations and cancer. Exposure to a single carcinogen usually leads to the formation of several types of DNA adducts, that may differ in their rate of formation and repair, as well as their biological effectivity. Benzola|pyrene (B[a]P) is often used as a representative for the PAH family in both in vitro and in vivo studies. Biotransformation of this compound results in four reactive stereoisomers; $( \pm$ )anti- and $( \pm)$ syn-benzo[a]pyrene-diol-epoxide (BPDE) (1). Anti-BPDE is reported to be more mutagenic than syn-BPDE. Moreover, (+)anti-BPDE has been found to possess higher biological activity than (-)anti-BPDE (3). So, theoretically, identification of pivotal DNA adducts measured at target sites or in well established surrogate tissues may improve the reliability of DNA adduct analysis in molecular epidemiological studies.

Sensitive immunological assays have been used to study the formation of aromatic bulky DNA adducts, but specific antibodies may cross-react with structurally related compounds and are therefore rather group specific than compound specific (4). Nowadays, the ${ }^{32} \mathrm{P}$-postlabeling assay with thin layer chromatography (TLC) is routinely applied. This assay is sensitive, but unable to distinguish between individual PAH-DNA adducts. Co-chromatography with a known DNA adduct is usually not sufficient for definite identification. Separation of ${ }^{32} \mathrm{P}$-postlabeled DNA adducts with HPLC seems to be a promising technique to detect specific DNA adducts formed upon exposure to complex mixtures $(5,6)$. Recently, an HPLC assay with fluorescence detection (HPLC-FD) was developed by Alexandrov et al. (7) that enables the separate analysis of stereoisomers of BPDE without the use of radioactivity. Although this technique is less sensitive, in DNA of $\mathrm{PAH}$ exposed coke oven workers the tetrols of $\mathrm{B}[\mathrm{a}] \mathrm{P}$ could be detected (8) and a good correlation between HPLC-FD and ${ }^{32} \mathrm{P}$-postlabeling was found in smoking lung cancer patients and aluminum workers (9). However, Pfau et al. (5) demonstrated that the major adducts formed by $\mathrm{B}[\mathrm{a}] \mathrm{P}$ and benzo[b]fluoranthene were not resolved on TLC. Thus, low resolution may trouble quantification of BPDE-DNA by 32Ppostlabeling in individuals exposed to complex chemical mixtures. In the present 
study, we applied the HPLC-FD technique in a controlled experimental setting of $\mathrm{B}$ [a]P exposed laboratory rodents. Since it is suggested that next to adduct types, adduct levels and persistence may be important factors in $\mathrm{B}[\mathrm{a}] \mathrm{P}$ induced carcinogenesis, adduct kinetics were examined over a period of 11 days by both techniques. For assessing the internal whole body dose, we additionally measured a urinary metabolite of $\mathrm{B}[\mathrm{a}] \mathrm{P}: 3-\mathrm{OH}-\mathrm{B}[\mathrm{a}] \mathrm{P}$.

\section{Materials \& Methods}

\section{Chemicals}

All solutions used were sterile. B[a]P was purchased from Sigma (St. Louis, MO, USA). All other chemicals were purchased from Merck (Darmstadt, Germany). Water was purified by means of a milli-Q purification system.

\section{Animal treatment}

Ten male Lewis rats weighing $270-320 \mathrm{~g}$ were used. The animals were housed individually in metabolic cages for collection of urine, in a room maintained at $25^{\circ} \mathrm{C}$, $50 \%$ humidity and a $12 \mathrm{hr}$ light/dark cycle. Standard rodent lab chow (dief no. RSMA, Hope Farms, Woerden, The Netherlands) and water were provided ad libitum. 24 hours-urine was collected. The samples were weighed and stored at $-20^{\circ} \mathrm{C}$ until analysis. B[a]P was initially dissolved in hexane and added to sunflower oil. Evaporation of the hexane resulted in a B[a]P concentration of $2 \mathrm{mg} / \mathrm{ml}$ oil. Eight rats were injected intra-peritoneally with $0.05 \mathrm{ml}$ of B[a]P-solution per 10 gram bodyweight to obtain a final dose of $10 \mathrm{mg} / \mathrm{kg}$ bodyweight. This treatment did not influence the eating and drinking behavior, as determined by reweighing the supplied food and water. Bodyweight, organ weight and urine excretion were constant during the experiment. To examine the time-course of adduct formation and persistence, the rats were killed 1, 2, 4 and 11 days after treatment (two rats per time-point). To assess background levels, 2 rats received sunflower oil only and were killed the following day. Lung, liver and heart were removed, washed with PBS and quickly frozen at $-20^{\circ} \mathrm{C}$ until DNA isolation.

\section{DNA isolation}

Approximately 1 gram of tissue was washed with $0.25 \mathrm{M}$ sucrose/ $0.1 \mathrm{M}$ Tris- $\mathrm{HCl}$ ( $\mathrm{pH} 7.4)$ and homogenized with a potter (1000 rpm) in $1 \%$ SDS/ 1 mM EDTA. The solutions were incubated overnight at $37^{\circ} \mathrm{C}$ with $0.5 \mathrm{mg}$ Proteinase $\mathrm{K}$. DNA was extracted with phenol: chloroform: isoamylalcohol $(25: 24: 1, \mathrm{v} / \mathrm{v} / \mathrm{v})$ and chloroform: isoamylalcohol $(24: 1, \mathrm{v} / \mathrm{v})$ respectively. The DNA was precipitated with two volumes of cold ethanol after addition of $1 / 30$ volume $3 \mathrm{M}$ sodiumacetate, $\mathrm{pH} 5.3$ and washed with $70 \%$ ethanol . Subsequently, DNA was dissolved in $5 \mathrm{mM}$ Tris/ 1 $\mathrm{mM}$ EDTA, pH 7.4. RNase T1 $(50 \mathrm{U} / \mathrm{ml})$ and RNase $\mathrm{A}(100 \mu \mathrm{g} / \mathrm{ml})$ were added, followed by $30^{\prime}$ of incubation at $37^{\circ} \mathrm{C}$. Liver DNA was also treated with $\alpha$-amylase $(50 \mu \mathrm{g} / \mu \mathrm{l})$. The solutions were extracted with respectively chloroform: isoamylalcohol $(24: 1, \mathrm{v} / \mathrm{v})$ and ether. DNA was precipitated from the aqueous phase with cold ethanol, washed with $70 \%$ ethanol and dissolved in $2 \mathrm{mM}$ Tris, $\mathrm{pH} 7,4$. 
Concentration and purity were determined spectrophotometrically by absorbance at 230,260 and $280 \mathrm{~nm}$. The final volume was adjusted to achieve a DNA-concentration of $2 \mathrm{mg} / \mathrm{ml}$.

\section{${ }^{32}$ P-postlabeling}

The ${ }^{32} \mathrm{P}$-postlabeling assay was performed as described by Reddy and Randerath (10) with some modifications. DNA (ca. $10 \mu \mathrm{g}$ ) was digested using micrococcal endonuclease ( 0.4 Units) and spleen phosphodiesterase $(2.8 \mu \mathrm{g})$ for 3 hours at $37^{\circ} \mathrm{C}$. Subsequently, half of the digest was treated with nuclease P1 $(6.3 \mu \mathrm{g})$ for 40 minutes at $37^{\circ} \mathrm{C}$. The modified nucleotides were labeled with $\left[\gamma^{-32} \mathrm{P}\right]-\mathrm{ATP}(50 \mu \mathrm{Ci} /$ sample) by incubation with T4-polynucleotide kinase (5.0 Units) for 30 minutes at $37^{\circ} \mathrm{C}$. $\left[\gamma^{32} \mathrm{P}\right]$ ATP was synthesized as described by Walseth and Johnson (11). NP1-efficiency and ATP-excess were checked with an aliquot of the NP1 treated fraction by one dimensional chromatography on poly(ethylenimine)(PEI)-cellulose sheets from Merck, Germany (solvent: $0.12 \mathrm{M} \mathrm{NaH}_{2} \mathrm{PO}_{4} \mathrm{PH}$ 6.8). Radiolabeled adduct nucleotide biphosphates were separated by chromatography on PEI-cellulose sheets from Machery Nagel, Germany. The following solvent systems were used: D1, 1 M $\mathrm{NaH}_{2} \mathrm{PO}_{4}$ pH6.5; D2, $8.5 \mathrm{M}$ urea, $5.3 \mathrm{M}$ lithiumformate $\mathrm{pH} 3.5 ; \mathrm{D} 3,1.2 \mathrm{M}$ lithiumchloride, $0.5 \mathrm{M}$ Tris, $8.5 \mathrm{M}$ urea $\mathrm{pH}$ 8.0; D4, $1.7 \mathrm{M} \mathrm{NaH}_{2} \mathrm{PO}_{4} \mathrm{pH}$ 6.0. Additionally, butanol extraction according to Gallagher et al. (12) was used as adduct enrichment method. In each experiment, 3 standards of $\left[{ }^{3} \mathrm{H}\right] \mathrm{BPDE}$ modified DNA with known modification levels ( 1 per $10^{7}, 10^{8}, 10^{9}$ nucleotides) were parallelly run for quantitation purposes. Quantitation was performed by using phosphor imaging technology (Molecular Dynamics ${ }^{\mathrm{TM}}$, Sunnyvale) with which detection limits of $<1$ adduct per $10^{9}$ nucleotides (nt.) can be obtained. The remaining half of the digest was used to determine the final amount of DNA in the assay; the normal nucleotides were labeled with $32 \mathrm{P}(15 \mu \mathrm{Ci} /$ sample) by incubation with T4polynucleotide kinase ( $2.5 \mathrm{Units}$ ) for 30 minutes at $37^{\circ} \mathrm{C}$. Nucleotides were separated by one dimensional chromatography on PEl-cellulose sheets from Merck (solvent: $0.12 \mathrm{M} \mathrm{NaH}_{2} \mathrm{PO}_{4} \mathrm{pH} 6.8$ ); samples with apparent protein or RNA contamination were discarded. A dAp standard ( $27.5 \mathrm{pmole} / \mu \mathrm{l})$ was labeled in each experiment for quantitation purposes. Interassay variation for BPDE-DNA was $17 \% \pm 5.5(n=13)$.

\section{B[a]P-Tetrol analysis with HPLC-FD}

The method used was initially described by Alexandrov et al. (7) and modified by Rojas et al. (9). Briefly, (i.) adducted DNA was hydrolyzed with $0.1 \mathrm{~N} \mathrm{HCl}$ for 4 hours at $90^{\circ} \mathrm{C}$. (ii.) BPDE-tetrols were concentrated on a pre-column. (iii.) C18-HPLC and monitoring of the fluorescence were performed as described by Alexandrov et al. (7). The fluorescence signals were integrated. The amount of B[a]P-tetrols in the samples and the detection limit were determined from a standard curve, generated from the fluorescence peak heights of BPDE-tetrol standards each time when analyzing a set of samples. The values thus obtained for $\mathrm{B}[\mathrm{a}] \mathrm{P}$-tetrols correspond to the quantities of BPDE-DNA adducts. Tetrol I-1 and tetrol II-2 represent adducts formed by respectively anti-BPDE and syn-BPDE. The amount of DNA used varied from 60 to $100 \mu \mathrm{g}$. The detection limit varied due to interassay variation: mean 
detection limits for tetrol $\mathbf{I}-1$ as well as II-2 were 0.8 per $10^{8} \mathrm{nt}$. (range 0.6-1.2; variation $27 \%$ ) for lung and 0.6 (range $0.5-0.9$; variation $21 \%$ ) for liver. For heart DNA the detection limits were 1.7 per $10^{8} \mathrm{nt}$. (range $0.6-2.9$; variation $47 \%$ ) for tetrol I-1 and 3.8 (range 1.1-7.4; variation $52 \%$ ) for tetrol II-2. Overall, the mean detection limit was 2.1 adducts per $10^{8} \mathrm{nt}$. (range $0.5-7.4$; variation $89 \%$ ).

\section{3-OH-B[a]P in rat urine}

Detection of 3-OH-B[a]P in 24-hours urine was performed as described by Jongeneelen et al. (13). The method consisted of enzymatic hydrolysis with Bglucuronidase and arylsulphatase, solid phase extraction on a Sep-pak C-18 cartridge and elution with methanol. Reversed phase HPLC (Kratos solvent delivery system; Column: Hypersil 5 ODS) and fluorescence detection (Perkin-Elmer LS-30) were employed, using excitation and emission wavelengths of $253 \mathrm{~nm}$ and $432 \mathrm{~nm}$. Peak area was used for quantification. The detection limit was $200 \mathrm{ng} 3-\mathrm{OH}-\mathrm{B}[\mathrm{a}] \mathrm{P}$ per liter urine. Day-to-day variation and intra-assay variation were respectively $14 \%$ and $6 \%$. For each rat, mean 24 hr urinary excretion of 3-OH-B[a]P was calculated as cumulative excretion divided by time (days) after exposure.

\section{Statistics}

Results are presented as mean \pm standard error of the mean. Correlation coefficients were calculated to examine the relation between BPDE-DNA adducts in several tissues determined by means of HPLC-FD and ${ }^{32} \mathrm{P}$-postlabeling. $\mathrm{P}<0.05$ is considered to be significant.

\section{Results}

Qualitative DNA adduct analysis in rat tissues by 32.P-postlabeling and HPLC.FD.

In all tissues studied, an adduct was detected by 32P-postlabeling (adduct 1) that comigrated with the [ $\left.{ }^{3} \mathrm{H}\right]$ BPDE-DNA standard (Figure 1, Panel A and B). Additionally, a second adduct (adduct 2) was detected in liver, lung and heart. Only in liver DNA a third major adduct was found (adduct 3) which had a higher migration rate in solvent D3, compared to the [3H]BPDE-DNA standard. Interestingly, this adduct did not appear in the chromatograms after butanol enrichment. Using HPLC-FD analysis, it was possible to detect BPDE-DNA adducts in heart and lung. In liver DNA, a fluorescence signal of tetrol I-1 was observed on day 2 , but this signal was equal to the arbitrary cut-off point of 0.9 adducts per $10^{8}$ nt. Thus in liver DNA, no BPDE-DNA adducts were detected in higher. concentrations than 0.9 adducts per $10^{8} \mathrm{nt}$.

\section{Quantitative results of adduct analysis in rat tissues}

32P-postlabeling of the DNA of the tissues studied showed similar adduct-time relationships over a period of 11 days (Figure 2). In lung, liver and heart, all DNA adduct levels increased to a maximum around day 4 . The maximal levels of adduct 1 in lung DNA $(3.1 \pm 0.9$ adducts per $108 \mathrm{nt}$. $)$ and liver DNA $(2.9 \pm 0.7)$ were about 2 times lower than in heart tissue $(6.3 \pm 0.6)$ (Figure 2-I). 


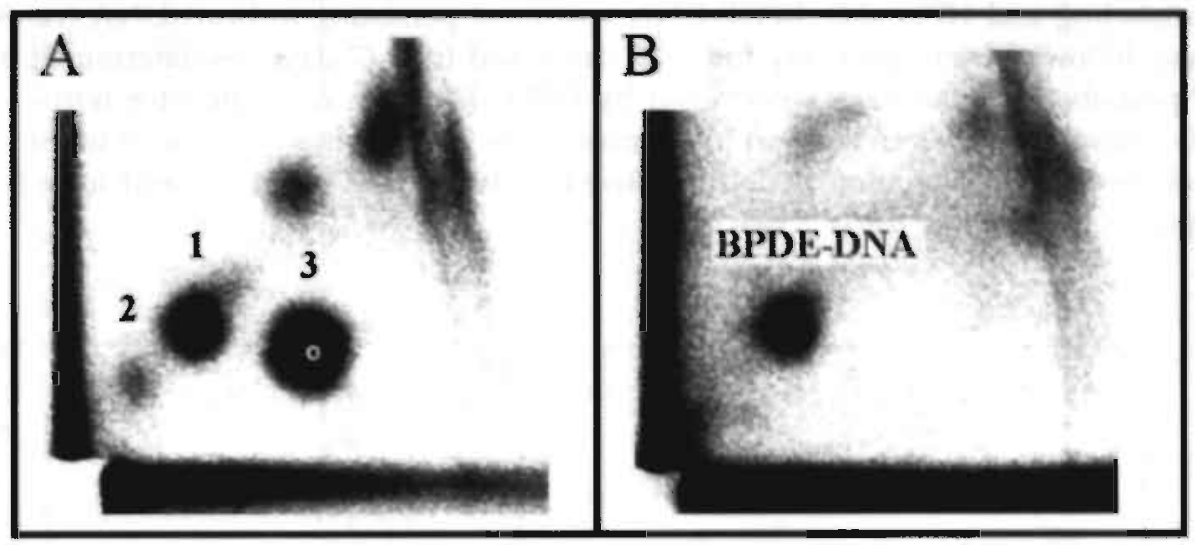

Figure 1. DNA adduct profiles determined by ${ }^{32} \mathrm{P}$-postlabeling. The origin is located at the lower left corner and was excised before analysis. All visible non-numbered spots were also found in rats treated with sunflower oil only. A: representative chromatogram of liver-DNA of B|a]P treated rats. B: [3H]BPDE modified DNA (1 adduct per $10^{8} \mathrm{nt}$.).

Adduct 2 also reached maximail levels at day 4 ; about 0.5 adducts per $10^{8} \mathrm{nt}$. in lung and liver, and 1 adduct per $10^{8} \mathrm{nt}$. in heart tissue. In liver DNA, spot 3 was the predominant one with a maximal level of $23.1 \pm 7.7$ adducts per $10^{8} \mathrm{nt}$. at day 4 . As a result, the ranking order of total tissue DNA adduct levels was liver $>$ heart $>$ lung as determined by ${ }^{32} \mathrm{P}-$ postlabeling (Figure 2-II). Although the putative BPDE-DNA adduct (spot 1) ranked heart $>$ lung $>$ liver.

In table 1 the results of the HPLC-FD analysis are summarized. In lung DNA only tetrol I-1 on day 4 and 11 could be quantitated, indicating a maximal adduct level of $1.4 \pm 0.1$ adducts per $10^{8} \mathrm{nt}$. At other time points, concentrations of I- 1 and II2 were below 1 adduct per $10^{8} \mathrm{nt}$. In heart tissue, both tetrol I-1 and II-2 were detected. Due to the relatively high detection limits, tetrol II-2 was found in a limited number of samples. At day 2, tetrol 1-1 concentrations reached up to $2.0 \pm 0.3$ adducts per $10^{8} \mathrm{nt}$, and remained stable until day $11\left(2.0 \pm 0.7\right.$ adducts per $10^{8} \mathrm{nt}$.). At any time-point, tetrol I-1 levels were not higher than 0.9 adducts per $10^{8} \mathrm{nt}$. in liver DNA. Suprisingly, on day 0 (control rats) in heart, tetrol I-1 could be detected by HPLC-FD as well as BPDE-DNA adducts were observed by ${ }^{32} \mathrm{P}$-postlabeling.

Overall, there is a good quantitative relationship between HPLC-FD and the 32P-postlabeling method; when BPDE-DNA adduct levels as determined by means of ${ }^{32} \mathrm{P}$-postlabeling were compared with total DNA adduct levels by HPLC-FD (i.e. tetrol I-1 plus II-2), a significant correlation coefficient of $0.95(p=0.01, n=5)$ was found, with a slope near to 1.0 (Figure 3). Furthermore, a good correlation was found between BPDE-DNA by ${ }^{32} \mathrm{P}$-postlabeling and tetroll $\mathrm{I}-1$ only $(\mathrm{r}=0.72$, $\mathrm{p}=0.006)$. 
The estimated half-lives of BPDE-DNA adducts in days were determined from the exponential decay curves of a log-linear plot as calculated on the basis of ${ }^{32} \mathrm{P}$ postlabeling and HPLC-FD. BPDE-DNA was most persisting in heart DNA (ca. 30 days), followed by respectively lung ( 23 days) and liver ( 7 days) as determined by 32P-postlabeling. Half-lives determined by HPLC-FD were calculated for tetrol I-1 only. Again, BPDE-DNA seemed to be most stable in heart (no decrease of tetrol I-1 levels over the observation period) followed by lung DNA (14 days) and liver ( $<4$ days).
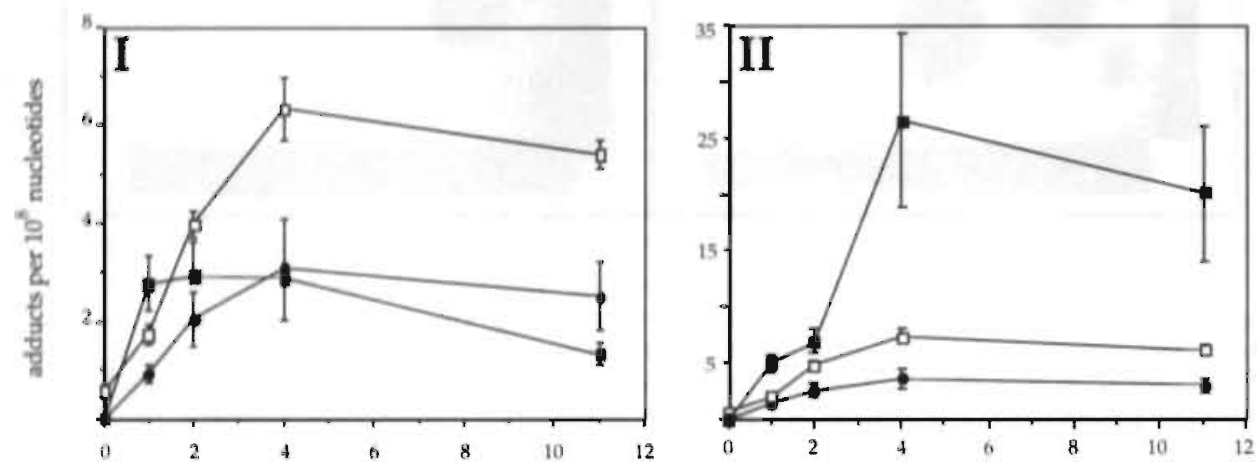

days after exposure

Figure 2. Kinetics of adduct levels in rat tissue ( $\mathrm{n}=2$ per time point) after a single injection of $10 \mathrm{mg}$ B[a]P / kg body weight. Adducts were detected by "P-postlabeling as described in Materials and Methods. Symbols: Liver (四) Heart (D) and Lung (e)(error bars sometimes within the size of the symbol), I: putative BPDE-DNA adduct levels, II: Total DNA adduct levels.

\section{3-OH-BlalP excretion in 24-hours urine}

To assess the internal dose, we measured a major $\mathrm{B}[\mathrm{a}] \mathrm{P}$ metabolite, 3-OH-B[a]P, in the 24-hours urine. Maximal values were observed at day 3 (251.8 $\pm 97.2 \mathrm{ng} / 24$ hours), after which the excretion gradually decreased to day 11. Cumulative excretion added up to only $889 \pm 270 \mathrm{ng}$, that is $0.03 \%( \pm 0.01 \%)$ of the total administered dose. Low levels of $3-\mathrm{OH}-\mathrm{B}[\mathrm{a}] \mathrm{P}$ were also found in rats receiving sunflower oil only $(4.9 \pm 0.5 \mathrm{ng} / 24$ hours). Generally, the excretion profile of 3-OH$\mathrm{B}[\mathrm{a}] \mathrm{P}$ did not correlate with the rate of DNA adduct formation in tissues. However, the mean $24 \mathrm{hr}$ excretion of 3-OH-B[a]P correlated with levels of DNA adducts in internal organs determined by ${ }^{32} \mathrm{P}$-postlabeling (Heart: $\mathrm{r}=0.68, \mathrm{p}=0.026$; Liver: $\mathrm{r}=$ $0.66, p=0.036$; Lung: $r=0.67, p=0.035$ )(Figure 4) and HPLC-FD (Heart: $r=0.86$, $\mathrm{p}=0.06)$. 


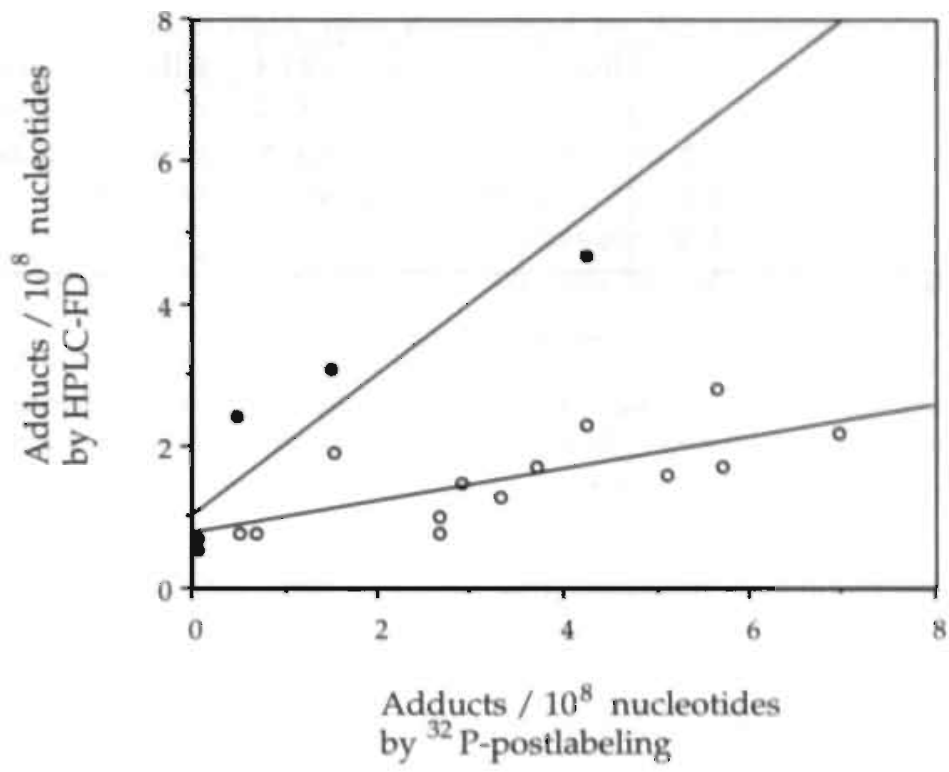

Figure 3. Relationship between BPDE-DNA adduct levels determined by ${ }^{32}$-postlabeling and HPLC. FD. (1) tetrol I-1 plus tetrol II-2 (tetrol II-2 was defected in heart tissue only); $r=0.95, p=0.01$ and (O) Tetrol I-1 only; $r=0.72, p=0.006$.

\section{Discussion}

Environmental and occupational exposure of humans mainly implies exposure to complex mixtures like PAH. Exposure to PAH results in a broad spectrum of different types of adducts of which specific types may account for most of the carcinogenicity (14). Therefore, identification of critical DNA adducts may be of major importance in the assessment of the biologically effective dose and subsequent risk estimates. Indeed, the results of a study by Denissenko et al. (15) suggest that BPDE-DNA adducts may play an important role in the etiology of human lung cancer. In this study, we found a good correlation between BPDE-DNA adduct quantification by means of the routinely used ${ }^{32} \mathrm{P}$-postlabeling and by a recently developed HPLC-FD assay in tissues of rats that were intraperitoneally exposed to $\mathrm{B}[\mathrm{a}] \mathrm{P}$. The major advantage of this HPLC-FD assay is the ability to identify BPDE isomers that have covalently bound to DNA. The most mutagenic and tumorigenic BPDE isomer in mammalian cells is anti-BPDE, which predominantly forms adducts with the exocyclic $\mathrm{N}^{2}$ amino group of guanine in DNA. This covalent binding process is believed to be an early event in $\mathrm{B}[\mathrm{a}] \mathrm{P}$ induced carcinogenesis. Previously, the HPLC-FD assay was applied to white blood cell DNA of aluminum workers and smoking lung cancer patients by Rojas et al. (9). Moreover, this assay was found to be sufficiently sensitive to detect BPDE-DNA adducts in coke oven workers (8); putative BPDE-DNA adduct 

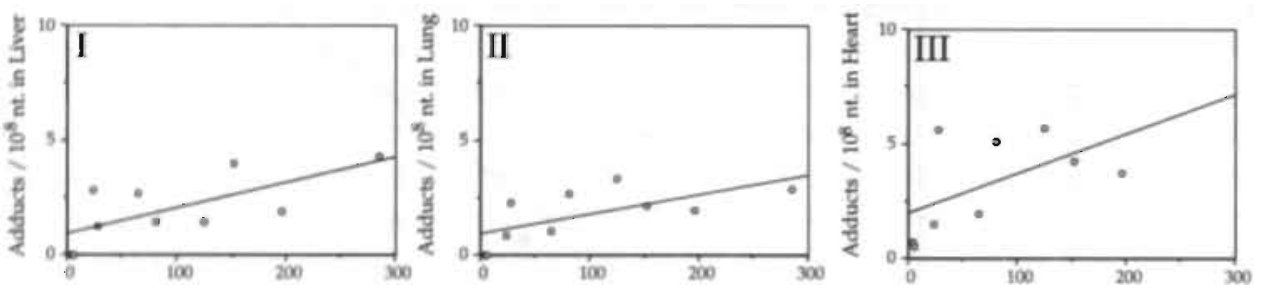

mean excretion of $3-\mathrm{OH}-\mathrm{BP}$ in $\mathrm{ng} / 24$ hours

Figure 4. Relationship between the mean 24 hours urinary excretion of $3-\mathrm{OH}-\mathrm{B}[\mathrm{a}] \mathrm{P}$ and BPDE-DNA adducts in tissues ( $I=$ Liver, $r=0.66, p=0.036$; $I=$ Lung, $r=0.67, p=0.035$; III $=$ Heart, $r=0.68, p=0.026$ ), determined by ${ }^{32} \mathrm{P}$-postlabeling.

levels in white blood cells determined by means of ${ }^{32} \mathrm{P}$-postlabeling were correlated with HPLC-FD. However, since these subjects were exposed to complex chemical mixtures and the resolution of TLC in ${ }^{32} \mathrm{P}$-postlabeling is low (5), unknown adducts may comigrate with the BPDE-DNA adduct spot. Therefore in the present study, an animal model was used with exposure to a single compound to further investigate the value of this technique.

$\mathrm{B}[\mathrm{a}] \mathrm{P}$ induced DNA adducts and carcinogenesis have been extensively studied in rats and a wide range of tumors was found, depending on the route of administration. Overall, the most important target sites seem to be pulmonary, gastric and mammary tissues $(14,16)$. Exposure via i.p. injection of $\mathrm{B}[\mathrm{a}] \mathrm{P}$ most frequently leads to the formation of tumors in the peritoneum and lung (17). Reasons for differences in tissue susceptibility are still under intensive investigation. Therefore, we also examined inter-organ differences with regard to maximal DNA adduct levels and adduct persistence. It should be mentioned, however, that accurate inter-organ comparisons for susceptibility to carcinogens can only be made with consideration of intra-organ cell heterogeneity, cell specific adducts and rates of cell. turnover.

After a single i.p. injection of $\mathrm{B}[\mathrm{a}] \mathrm{P}$, using ${ }^{32 \mathrm{P}}$-postlabeling we found highest total adduct levels in liver $>$ heart $>$ lung. Other studies found similar adduct distributions and kinetics in rat organs after i.p. exposure to $B[a] P(16,18)$. In these studies, peak DNA adduct levels were also observed at approximately 3-4 days after a single i.p. administration of B[a]P". Although the lung is a major site for B[a]Pcarcinogenesis, the total amount of liver and heart DNA adducts at day 4 after exposure was much higher. This indicates that there is no quantitative relationship between the extent of covalent reaction of B[a]P metabolites with DNA and tissue susceptibility for tumor induction. Differences in adduct types and adduct conformation may be involved (19). With respect to adduct types, using the HPLCFD assay we found higher levels of B[a]P tetrol I-1 in lung compared to liver DNA. The I-1 tetrol derives from hydrolysis of anti-BPDE, which is known to be the most potent tumor inducing form of BPDE (1). On the contrary, maximal putative BPDEDNA adduct levels determined by ${ }^{32} \mathrm{P}$-postlabeling were not significantly different for lung $(3.1 \pm 0.9)$ and liver $(2.9 \pm 0.7)$. A possible explanation for this discrepancy is 
that in liver the BPDE-DNA spot determined by 32P-postlabeling may contain adducts formed by multiple BPDE-isomers. Using HPLC-FD however, the separate tetrol levels were not higher than the detection limit for liver DNA. In lung, the BPDE-DNA spot is predominantly formed by tetrol $1-1(>45 \%)$, that can be detected by HPLC-FD. In those samples in which both tetrol I-1 and II-2 were detected, a good correlation between both techniques was found $(r=0.95)$. HPLC-FD analysis resulted in highest adduct levels in respectively heart, lung and liver. In the present study, using a high dose of B[a]P and large quantities of DNA, most tissues analyzed seemed to contain adduct levels at or below the detection limits of the HPLC-FD assay. These findings could question the applicability of HIPLC-FD in human biomonitoring. However, several studies already showed that this assay is sufficiently sensitive to detect BPDE-DNA in human lung, aorta, colon mucosa and also in lymphocytes of cigarette smokers and occupationally exposed individuals (79, 20, 21). Another advantage of this technique is that it does not require the application of radioactivity.

Table I. BPDE-DNA adduct levels (adducts per $10^{8}$ nucleotides) determined by HPLC-FD in rats acutely exposed to B[a]P.

\begin{tabular}{lllll} 
Day & $\begin{array}{l}\text { Liver } \\
\text { Tetrol I-1 }\end{array}$ & $\begin{array}{l}\text { Lung } \\
\text { Tetrol I-1 }\end{array}$ & \multicolumn{2}{c}{ Heart } \\
\cline { 4 - 5 } & & & & Tetrol I-1 \\
& $<0.5^{*}$ & $<0.7$ & $0.8 \pm 0.0$ & $1.6^{* *}$ \\
0 & $<0.8$ & $<0.6$ & $1.9^{* *}$ & $1.2^{* *}$ \\
1 & $\bullet 0.9$ & $<1.2$ & $2.0 \pm 0.3$ & $2.7^{* *}$ \\
2 & $<0.5$ & $1.4 \pm 0.1$ & $2.0 \pm 0.3$ & $<.9$ \\
4 & $<0.6$ & $1.0^{* *}$ & $2.0 \pm 0.7$ & $<5.6$ \\
11 & & & &
\end{tabular}

\footnotetext{
- DNA adduct level below detection limit as indicated

* Single value; other sample below detection limit
}

Differences in adduct persistence have also been suggested to be involved in tumorigenesis. In our experiment the persistence of total adduct levels, determined by ${ }^{32}$ P-postlabeling, was similar between liver and lung. By contrast, the persistence of BPDE-DNA adducts was highest in heart followed by respectively lung and liver calculated on basis of ${ }^{32} \mathrm{P}$-postlabeling. Estimated half-lives calculated on basis of HPLC-FD (tetrol I-1 only) were similar as compared with ${ }^{32} \mathrm{P}$-postlabeling. Furthermore, these results are in agreement with Nesnow et al. (18) and Qu et al. (22) after respectively single or multiple i.p. administrations of B[a]P. However, adduct persistence alone is not sufficient to explain the tumorigenic potencies of PAH (14). High adduct levels and adduct persistence in heart will rarely lead to tumor formation, because heart muscle cells do not proliferate, which is a prerequisite for the fixation of DNA damage. In short, the level and persistence of BPDE-DNA in lung and liver coincides with the tissue's susceptibility for tumor induction and may therefore be of importance in the assessment of the biologically effective dose. By 
${ }^{32} \mathrm{P}$-postlabeling, information about the characteristics and identity of an unknown adduct can only be obtained if several solvent systems or enrichment procedures are used. For instance, adduct 3 (Figure 1) was NP1 resistant, but could not be found after using the butanol enrichment method. Obviously, this compound is not sufficiently hydrophobic to be extracted with butanol.

Additionally, we have studied the excretion of $3-\mathrm{OH}-\mathrm{B}[\mathrm{a}] \mathrm{P}$ as a measure of the internal whole body dose. The excretion of 3-OH-B[a]P reached a maximum on day 3 and the cumulative excretion added up to only $0.03 \%$ of the total dose of exposure. 3$\mathrm{OH}-\mathrm{B}[\mathrm{a}] \mathrm{P}$ kinetics did not coincide with adduct levels in tissues. Nonetheless, at the individual level significant correlations were found between the mean $24 \mathrm{hr}$ excretion of 3-OH-B[a]P and DNA adduct levels in organs, i.e. rats with a higher excretion of 3-OH-Bia]P had higher adduct levels in lung, liver or heart tissue determined by ${ }^{32} \mathrm{P}$-postlabeling and HPLC.FD. Thus, monitoring the urinary excretion of 3-OH-B[a]P over a prolonged period of time may reflect DNA adduct formation in internal organs, while a single measurement of 3-OH-B[a]P in the urine does not. Furthermore, Likhachev et al. (23) found high levels of B[a]P-7,8-diol, a precursor of $\mathrm{BPDE}$, in the urine of $\mathrm{B}[\mathrm{a}] \mathrm{P}$ exposed rats, which correlated with the latency of tumor formation. We also found a urinary compound with cochromatographic characteristics of B[a]P-7,8-diol, but spectrum analysis showed that this compound was not $B[a] P-7,8$-diol (data not shown).

A thorough understanding of the formation of DNA adduct types in target-cells or a well established surrogate source of exposed DNA will permit us to use PAHDNA adducts as an effective biomarker (24). Our results show that adduct identification by means of HPLC-FD might increase the applicability of DNA adduct measurements in the assessment of the biologically effective dose. The ${ }^{32} \mathrm{P}$ postlabeling assay is sensitive and capable of detecting exposures to complex mixtures. On the other hand, the HPLC-FD assay can be used to identify BPDEisomers with different biological effects and might therefore be of value in risk assessment of individuals exposed to PAH.

\section{References}

1. Hall, M., and Grover, P.L. (1990) Polycyclic aromatic hydrocarbons: metabolism, activation, tumor-initiation. In: C.S. Cooper and P.L. Grover (eds), Chemical carcinogenesis and mutagenesis, Raven Press, New York, vol. 1, 327-372.

2. Hemminki, K. (1993) DNA adducts, mutations and cancer, Carcinogenesis, 14, 20072012.

3. Zanesi, N., Ferraro, P., Pavanello, S., Furlan D., Celotti, L. (1994) Cytotoxic and mutagenic effects of anti- and syn benzo(a)pyrene diol epoxide in human lymphocytes, Toxicol in Vitro, 8, 1269-1275.

4. Van Schooten, F.J., Kriek, E., Steenwinkel, M.J.S.T., Noteborn, H.P.J.M., Hillebrand, M.J.X., Van Leeuwen, F.E. (1987) The binding efficiency of polyclonal and monoclonal antibodies to DNA modified with benzo(a)pyrene diol epoxide is dependent on the 
level of modification. Implications for quantitation of benzo(a)pyrene-DNA adducts in vivo. Carcinogenesis, 8, 1263-1269.

5. Pfau, W., Lecoq, S., Hughes, N.C., Grover, P.L., Phillips, D.H. (1993) Separation of 32Ppostlabelled nucleoside 3',5'-biphosphate adducts by HPLC. In: D.H. Phillips, M. Castegnaro, and $\mathrm{H}$. Bartsch (eds) Postlabeling methods for detection of DNA adducts, IARC scientific publications, no. 124, 233-242.

6. Möller, L., Zeisig, M., Vodicka, P. (1993) Optimization of an HPLC method for analysis of ${ }^{32} \mathrm{P}$-postlabeled DNA adducts. Carcinogenesis, 14, 1343-1348.

7. Alexandrov, K., Rojas, M., Geneste, O., Castegnaro, M., Camus, A-M., Petruzzelli, S., Giuntini C., Bartsch, H. (1992) An Improved fluorometric assay for dosimetry of benzo(a)pyrene diol epoxide DNA adducts in smokers' lung: comparisons with total bulky adducts and aryl hydrocarbon hydroxylase activity. Cancer Res, 52, 6248-6253.

8. Rojas, M., Alexandrov, K., Auburtin, C., Wastiaux-Denamur, A., Mayer, L., Mathieu, B., Sebastien P., Bartsch, H. (1995) Anti-benzo(a)pyrene diolepoxide-DNA adduct levels in peripheral mononuclear cells from coke oven workers and the enhancing effect of smoking, Carcinogenesis. 16, 1373-1376.

9. Rojas, M., Alexandrov, K., Van Schooten, F.J., Hillebrand, M.J.X., Kriek, E., Bartsch, H. (1994)Validation of a new fluorometric assay for Benzo(a)pyrene diolepoxide-DNA adducts in human white blood cells: comparisons with ${ }^{32} \mathrm{P}$-postlabeling and ELISA, Carcinogenesis. 15, 557-560.

10. Reddy, M.V., Randerath, K. (1986) Nuclease P1 mediated enhancement of sensitivity of ${ }^{32} \mathrm{P}$-postlabeling test for structurally diverse DNA-adducts, Carcinogenesis. 7, 15431551.

11. Walseth, T.H., Johnson, R.A. (1979) The enzymatic preparation of $\left[\alpha^{32} \mathrm{P}\right]$ nucleoside triphosphates, cyclic [32P]AMP and cyclic [32P]GMP. Biochim. Biophys. Acta., 562, 1131.

12. Gallagher, J.E., Jackson, M.A., George, M.H., Lewtas, J., Robertson, I.G.C. (1989) Differences in detection of DNA adducts in the ${ }^{32} \mathrm{P}$-postlabeling assay after either 1butanol extraction or nuclease P1 treatment. Cancer Lett., 45, 7-12.

13. Jongeneelen, F.J., Bos, R.P., Anzion, R.B.M., Theeuws, J.L.G., Henderson, P.T. (1986) Biological monitoring of polycyclic aromatic hydrocarbons in urine. Scand. I. Work Environ. Health, 12, 137-143.

14. Ross, J., Nelson, G.B., Wilson, K.H., Rabinowitz, J.R., Galati, A., Stoner, G.D., Nesnow, S., Mass M.J. (1995), Adenomas induced by $\mathrm{PAH}$ in strain $\mathrm{A} / \mathrm{J}$ mouse lung correlates with time integrated DNA adduct levels. Cancer Res., 55, 1039-1044.

15. Denissenko, M.F., Pao, A., Tang, M., Pfeifer, G.P. (1996) Preferential formation of benzo[a]pyrene adducts at lung cancer mutational hotspots in P53. Science, 274 , 430432.

16. Ross, J., Nelson, G., Kligerman, A., Erexson, G., Bryant, M., Gupta, R., Nesnow, S. (1990) Formation and persistence of novel B[a]P adducts in rat lung and peripheral blood lymphocyte DNA. Cancer Res., 50, 5088-5094.

17. Tyndyk, M.L., Zabezhinski, M.A., Bykov, V.J., Dikun, P.P., Dymochka, L.A., Nepomnyasshaya, O.B., Yatsuk, O.S., Yermilov, V.B., Likhachev, A.J. (1994) Individual values of excretion of $\mathrm{B}[\mathrm{a}] \mathrm{P}$ metabolites and susceptibility to its carcinogenic effect in rats. Cancer Lett., 78, 163-170.

18. Nesnow, S., Ross, J., Nelson, G., Holden, K., Erexson, G., Kligerman, A., Gupta, R.C. (1993) Quantitative and temporal relationship between DNA adduct formation in target and surrogate tissues: implications for biomonitoring. Environ. Health Perspect.r $101,37-42$.

19. Suh, M., Ariese, F., Small, G.J., Jankowiak, R., Hewer, A., Phillips, D.H. (1995) Formation and persistence of benzo(a)pyrene-DNA adducts in mouse epidermis in vivo: importance of adduct conformation. Carcinogenesis, 16, 2561-2569.

20. Izotti, A., De Flora, S., Petrilli, G.L., Gallagher, J., Rojas, M., Alexandrov, K., Bartsch, H., Lewtas, J. (1995) Cancer biomarkers in human atherosclerotic lesions: detection of DNA adducts. Cancer Epidemiol. Biomarkers and Prev., 4, 105-110. 
21. Alexandrov, K., Rojas, M., Kadlubar, F.F., Lang, N.P., Bartsch, H. (1996) Evidence of anti-benzo[a]pyrene diolepoxide-DNA adduct formation in human colon mucosa. Carcinogenesis, 17, 2081-2083.

22. Qu, S.X., Stacey, N.H. (1996) Formation and persistence of DNA adducts in different target tissues of rats after multiple administrations of benzo(a)pyrene. Carcinogenesis, $17,53-59$.

23. Likhachev, A.J., Beniahvili, D.Sh., Bykov, V.J., Dikun, P.P., Tyndyk, M.L., Savochkina, I.V., Yermilov, V.B., Zabezhinski, M.A. (1992) Biomarkers for individual susceptibility to carcinogenic agents: Excretion and carcinogenic risk of $\mathrm{B}[\mathrm{a}] \mathrm{P}$ metabolites, Environ. Health Perspect., 98, 211-214.

24. Schulte, P.A., Perera, F.P. (1993) Validation. In: Schulte, P.A., Perera, F.P. (eds), Molecular Epidemiology: principles and practices. Academic Press, New York. 


\title{
Chapter 11
}

\section{Influences of DNA isolation and RNA contamination on carcinogen- DNA adduct analysis by ${ }^{32}$ P-postlabeling}

\author{
R.W.L. Godschalk, L.M. Maas, J.C.S. Kleinjans, F.J. van Schooten \\ Department of Health Risk Analysis and Toxicology, \\ University of Maastricht, Maastricht, The Netherlands
}

Environmental \& Molecular Mutagenesis, vol. 32 pp 344-350, 1998

\begin{abstract}
${ }^{32} \mathrm{P}$-postlabeling is a widely applied assay for the analysis of carcinogen-DNA adducts. Optimization of most steps in this assay has been given attention, but influences of DNA isolation and DNA purity on adduct quantitation have not been investigated systematically. In this study, DNA was isolated from human lymphocytes exposed to benzo[a]pyrene $(\mathrm{B}[\mathrm{a}] \mathrm{P}, 10 \mu \mathrm{M})$ for 18 hours and from liver of rats i.p. treated with B[a]P (10 mg/ $\mathrm{kg}$ body weight) using two different DNA isolation methods: a phenol-extraction and a salting out procedure. Subsequently, DNA was analyzed by nuclease P1 (NP1) or butanol enriched 32P-postlabeling. Influences of RNA-contamination were studied by labeling RNA, isolated from in vitro exposed iymphocytes. In the in vitro experiment, DNA adduct levels were significantly higher using the salting out procedure $\left(63.2 \pm 13.7\right.$ adducts per $10^{8}$ nucleotides, $\mathrm{n}=9$ ) as compared with the phenol-extraction. (14.3 \pm 0.8$)$. RNA was ca. 4 times less efficiently labeled as compared. to DNA. Nonetheless, RNA contamination of DNA samples may' result in an overestimation. of DNA adduct levels when butanol enrichment is used, because RNA adduct levels seemed to be substantially higher than DNA adduct levels in the same cells. DNA adduct analysis by nuclease P1 enrichment is probably less affected, since RNA adducts appeared to be NP1 sensitive. In vivo, three different adducts were found by NP1 enriched 32P'postlabeling in the liver of B[a]P exposed rats. Again, DNA adduct levels were significantly higher using salting out as compared to phenol extraction for the adduct which comigrated with the BPDE-DNA adduct standard (adduct 1) and an unknown adduct (adduct 2). However, the results were the opposite for another $\mathrm{B}[\mathrm{a}] \mathrm{P}$-derived DNA adduct (adduct 3 ). Our results suggest that differences in DNA isolation procedures as well as RNA contamination influence quantitative DNA adduct analysis by ${ }^{32} \mathrm{P}$-postlabeling.
\end{abstract}

\section{Introduction}

Binding of carcinogens to DNA is thought to play a crucial role in the multistep process of carcinogenesis. Therefore, DNA adduct measurements are considered to be a relevant indicator for carcinogen exposure. Several studies even aimed at providing an improved basis for risk assessment by DNA-adduct measurements. (1, 2). However, for these purposes sensitive and accurate assays are obligatory. Several methods for DNA adduct analysis have been developed during the last two decades. At this moment $32 \mathrm{P}$-postlabeling is the most sensitive assay that can be applied to 
detect several kinds of DNA damages such as bulky-DNA adducts (3), oxidative and UV-irradiation-induced damage (4), alkylated bases (5) or apurinic sites (6). An advantage of ${ }^{32} \mathrm{P}$-postlabeling is that it needs only small amounts of DNA, which makes this assay suitable for the analysis of human (biopsy) samples. A disadvantage of this assay is its inability to identify adduct types. In this area, other assays have been developed, such as HPLC-FD (7) or ${ }^{32}$ P-postlabeling combined with HPLC and on-line detection of radioactivity (8), but these assays never reached the defection limits obtained by ${ }^{32} \mathrm{P}$-postlabeling with TLC. Many steps in the ${ }^{32} \mathrm{P}$ postlabeling assay are optimized especially for bulky-DNA adducts and under optimal conditions detection limits of one adduct per $10^{9}-10^{10}$ nucleotides are reported (9). However, some aspects that may influence adduct analysis, are underrecognized. For example, proper DNA isolation is a critical step for ${ }^{32} \mathrm{P}$ postlabeling, but the exact influences of different DNA isolation techniques on adduct recoveries are largely uninvestigated. Furthermore, impurities of DNA samples may hamper accurate quantitative analysis and this problem certainly deserves more attention. The ${ }^{32} \mathrm{P}$-postlabeling assay was originally developed to study nucleic acids including RNA-derived ribonucleotides (10) and therefore, contamination of DNA samples by RNA may be a disturbing factor, because normal and adducted RNA nucleotides may additionally be labeled. Additionally, RNA contamination may interfere when assessing the DN.A content by spectrophotometrical analysis. In the present study, DNA adducts were analyzed by nuclease P1 (NP1) as well as butanol enriched ${ }^{32} \mathrm{P}$-postlabeling in lymphocytes after 18 hours of in vitro exposure to $10 \mu \mathrm{M}$ benzo[a]pyrene $(\mathrm{B}[\mathrm{a}] \mathrm{P})$ and in liver-DNA of rats i.p. treated with $10 \mathrm{mg}$ B[a]P per $\mathrm{kg}$ body weight. DNA was isolated by a routinely used phenol extraction method (11) and a salting out procedure as described by Miller et al. (12). From the in vitro treated cells also RNA was isolated by a procedure based on phenol extraction, analyzed by ${ }^{32}$ P-postlabeling and subsequently compared with DNA adduct levels.

\section{Materials \& Methods}

\section{Chemicals}

All solutions used were sterile. B[a]P was purchased from Sigma (St. Louis, MO, USA). RPMI 1640, streptomycin/penicillin, L-glutamin and fetal calf serum (FCS) were all obtained from Gibco (Europe). Lymphoprep ${ }^{\mathrm{TM}}(1.077 \mathrm{~g} / \mathrm{ml})$ was obtained from Nycomed (Oslo, Norway). All other chemicals were purchased from Merck (Darmstadt, Germany). Water was purified by means of a milli-Q purification system.

\section{Isolation and incubation of lymphocytes}

Ten $\mathrm{ml}$ of peripheral blood of nine healthy nonsmoking volunteers was sampled by venapuncture into EDTA-tubes. Polymorphonuclear cells (granulocytes) were separated from lymphocytes and monocytes by gradient centrifugation on lymphoprep according to Bøyum (13). Mononuclear cell fractions were washed with PBS and suspended at a concentration of $2 \times 10^{6}$ cells $/ \mathrm{ml}$ in RPMI 1640, 
supplemented with $10 \%$ FCS, $2 \mathrm{mM} \mathrm{L}$-glutamin, $10 \mathrm{IU} / \mathrm{ml}$ penicillin and $10 \mu \mathrm{g} / \mathrm{ml}$ streptomycin. B[a]P was dissolved in dimethylsulfoxide (DMSO) and added to the cells to yield a final concentration of $10 \mu \mathrm{M}$. In all incubations the DMSO concentration did not exceed $0.5 \%$. Cells were incubated for 18 hours $\left(37^{\circ} \mathrm{C}, 5 \% \mathrm{CO}_{2}\right.$ : $95 \% \mathrm{O}_{2}$ ). Viability was checked by means of trypan-blue exclusion. After the incubations, cells were collected by centrifugation, washed with PBS and stored at $20^{\circ} \mathrm{C}$ until DNA/RNA isolation.

\section{Treatment of Lewis rats with Benzolalpyrene}

Six male Lewis rats weighing $270-320 \mathrm{~g}$ were used. The animals were housed individually in a room maintained at $25^{\circ} \mathrm{C}, 50 \%$ humidity and a $12 \mathrm{hr}$ light/dark cycle. Standard rodent lab chow (diet no. RSM-A, Hope Farms, Woerden, The Netherlands) and water were provided ad libitum. B[a]P was initially dissolved in hexane and added to sunflower oil. Evaporation of the hexane resulted in a B[a]P concentration of $2 \mathrm{mg} / \mathrm{ml}$ oil. Rats were injected intra-peritoneally with $0.05 \mathrm{ml}$ of $\mathrm{B}[\mathrm{a}] \mathrm{P}$-solution per $10 \mathrm{gram}$ bodyweight to obtain a final dose of $10 \mathrm{mg} / \mathrm{kg}$ bodyweight. This treatment did not influence the eating and drinking behavior, as determined by reweighing the supplied food and water. Rats were killed at 2, 4 and 11 days after treatment (two rats per time-point). The liver was removed, washed with PBS and quickly frozen at $-20^{\circ} \mathrm{C}$ until DNA isolation.

\section{DNA isolation procedures}

Lymphocytes were lysed with $2.5 \mathrm{ml}$ SDS/NEP $(75 \mathrm{mM} \mathrm{NaCl}, 25 \mathrm{mM}$ EDTA, 50 $\mathrm{mg} / \mathrm{ml}$ Proteinase $\mathrm{K}, 1 \% \mathrm{SDS}$ ) and incubated for 4 hours at $37^{\circ} \mathrm{C}$. Approximately 1 gram of liver was washed with $0.25 \mathrm{M}$ sucrose/ $0.1 \mathrm{M}$ Tris- $\mathrm{HCl}(\mathrm{pH} 7.4)$ and homogenized with a potter $(1000 \mathrm{rpm})$ in $1 \% \mathrm{SDS} / 1 \mathrm{mM}$ EDTA and subsequently incubated overnight at $37^{\circ} \mathrm{C}$ with $0.5 \mathrm{mg}$ Proteinase $\mathrm{K}$.

Phenol extraction (11); samples were extracted with equal volumes of phenol: chloroform: isoamylalcohol (25:24:1, v/v/v) and chloroform: isoamylalcohol (24:1, $\mathrm{v} / \mathrm{v}$ ) respectively. DNA was precipitated with two volumes of cold ethanol after addition of $1 / 30$ volume $3 \mathrm{M}$ sodiumacetate, $\mathrm{pH} 5.3$ and washed with $70 \%$ ethanol.

Salting out procedure, i.e. selective precipitation by $\mathrm{NaCl}$ and ethanol (12); $1 / 3$ volume of $6 \mathrm{M} \mathrm{NaCl}$ was added to precipitate the proteins. Additionally, the aqueous phase was once extracted. with chloroform: isoamylalcohol $(24: 1, \mathrm{v} / \mathrm{v})$. DNA was precipitated with two volumes of cold ethanol and washed with $70 \%$ ethanol.

DNA samples were treated with RNase A $(100 \mu \mathrm{g} / \mathrm{ml})$ and $\mathrm{T} 1(50 \mathrm{U} / \mathrm{ml})$ for $30 \mathrm{~min}$. at $37^{\circ} \mathrm{C}$ and once extracted with chloroform: isoamylalcohol $(24: 1, \mathrm{v} / \mathrm{v})$. Subsequently, DNA was reprecipitated and dissolved in $2 \mathrm{mM}$ Tris, $\mathrm{pH}$ 7,4. Concentration and purity were determined spectrophotometrically by absorbance at 230, 260 and $280 \mathrm{~nm}$ (Table I). The final volume was adjusted to achieve a DNAconcentration of $2 \mathrm{mg} / \mathrm{ml}\left(1 \mathrm{OD}_{260}=50 \mu \mathrm{g} / \mu \mathrm{l}\right)$.

\section{RNA isolation procedure}

RNA was isolated according to Chomczynski and Sacchi (14). The denaturing solution was $4 \mathrm{M}$ guanidinium-thiocyanate, $25 \mathrm{mM}$ sodium citrate, $\mathrm{pH} 7.0 ; 0.5 \%$ 
sarcosyl, 0.1 M B-mercapto ethanol. After addition of $2 \mathrm{M}$ sodium acetate ( $\mathrm{pH} 4.0$ ), the aqueous phase was extracted with phenol and chloroform:isoamyl alcohol (49:1). The RNA was precipitated with 1 volume of cold isopropanol after addition of $1 / 20$ volume of $2 \mathrm{M}$ sodiumacetate. Subsequently, RNA was obtained by centrifugation at $10,000 \mathrm{~g}$ for 15 minutes at $4^{\circ} \mathrm{C}$ and washed with respectively the denaturing solution as described above and $70 \%$ ethanol. Finally, RNA was dissolved in $2 \mathrm{mM}$ Tris, pH 7.4. Concentration and purity were determined spectrophotometrically by absorbance at 230, 260 and $280 \mathrm{~nm}$ (Table I). The final volume was adjusted to achieve a RNA-concentration of $2 \mathrm{mg} / \mathrm{ml}\left(1 \mathrm{OD}_{260}=40 \mu \mathrm{g} / \mu \mathrm{l}\right)$.

\section{${ }^{32}$ P-postlabeling analysis}

The NP1 enriched ${ }^{32} \mathrm{P}$-postlabeling assay was performed as described by Van Schooten et al. (15). Butanol enrichment was applied as described by Gallagher et al. (16). NP1-efficiency, removal of normal nucleotides by butanol extraction and ATPexcess were checked with an aliquot of the enriched fractions by one-dimensional chromatography on poly(ethyleneimine)(PEI)-cellulose sheets from Merck, Germany (solvent: $0.12 \mathrm{M} \mathrm{NaH}_{2} \mathrm{PO}_{4}, \mathrm{pH}$ 6.8). Radiolabeled adduct nucleotide biphosphates were separated by chromatography on PEI-celiulose sheets from Machery Nagel (Germany). The following solvent systems were used: D1, $1 \mathrm{M} \mathrm{NaH}_{2} \mathrm{PO}_{4} \mathrm{pH}$ i.5; D2, $8.5 \mathrm{M}$ urea, $5.3 \mathrm{M}$ lithium formate $\mathrm{pH} 3.5 ; \mathrm{D} 3,1.2 \mathrm{M}$ lithium chloride, $0.5 \mathrm{M}$ Tris, 8.5 $\mathrm{M}$ urea $\mathrm{pH}$ 8.0; $\mathrm{D} 4,1.7 \mathrm{M} \mathrm{NaH}_{2} \mathrm{PO}_{4} \mathrm{pH}$ 6.0. In each experiment, 3 standards of $\left[{ }^{3} \mathrm{H}\right] \mathrm{BPDE}$ modified DNA with known modification levels $\left(1\right.$ per $10^{7}, 10^{8}, 10^{9}$ nucleotides) were run parallelly. Quantification was performed by using phosphorimaging technology (Molecular Dynamics ${ }^{\mathrm{TM}}$, Sunnyvale, CA, USA). The final amount of DNA in the assay was determined by dilution and labeling of normal nucleotides with excess $\left[\gamma^{32} \mathrm{P}\right]-\mathrm{ATP}(15 \mu \mathrm{Ci} / \mathrm{sample})$ by incubation with T4polynucleotide kinase (2.5 Units) for 30 minutes at $37^{\circ} \mathrm{C}$. Excess of ATP was removed by incubation with apyrase $(12.5 \mathrm{mU})$ for $30 \mathrm{~min}$. at $37^{\circ} \mathrm{C}$. Nucleotides were separated by one-dimensional chromatography on PEI-cellulose sheets from Merck (solvent: $0.12 \mathrm{M} \mathrm{NaH}_{2} \mathrm{PO}_{4} \mathrm{pH}$ 6.8). A dAp standard (27.5 pmole/ $\mu \mathrm{l}$ ) was labeled in each experiment for quantification purposes. Interassay variation was $<25 \%$.

\section{Statistics}

Data are presented as mean \pm standard error of the mean. Non-parametric tests for paired samples (Wilcoxon signed rank tests) were applied to evaluate the statistical significance of differences between DNA isolation methodologies. $\mathrm{P}<0.05$ was: considered significant.

\section{Results}

\section{Qualitative and quantitative results of DNA/ RNA isolation and labeling}

For pure DNA, the spectral ratio A260/A280 should be $\sim 1.8$ and the ratio A230/A.260 0.45. All DNA samples had ratios near these theoretical values as shown in Table I, except for rat-liver DNA isolated by the salting out procedure (A260/ A280: $1.67 \pm 0.01$ ), which indicates that in these samples some residual proteins were 
present. The maximum absorption was found at $\sim 260 \mathrm{~nm}$, which indicates that the DNA was not significantly contaminated with RNA, since RNA contamination would result in a shift of the maximum towards $250 \mathrm{~nm}$. Protein contamination might result in a tailing spot at the origin in the labeling experiment. However, after labeling an aliquot of the digested DNA and subsequent TLC separation of normal nucleotides with $0.12 \mathrm{M} \mathrm{NaH}_{2} \mathrm{PO}_{4}$ (pH 6.8), no tailing was observed (a typical chromatograph is shown in Figure 1). For RNA, a spectral ratio A260/A280 of $2.07 \pm 0.10$ (Table D) was found, which is in line with the theoretical value of $\sim 2.0$. Furthermore, in the chromatographs, no additional DNA-spots were observed, from which it can be deduced that contamination with DNA is $<1 \%$.

Table I. Purity information on DNA and RNA samples after phenol extraction or salting out procedure as described in Materials and Methods section of human lymphocytes and rat liver.

\begin{tabular}{|c|c|c|c|c|c|}
\hline & \multicolumn{3}{|c|}{ Phenol extraction } & \multicolumn{2}{|c|}{ Salting out Procedure } \\
\hline & $\begin{array}{c}\text { DNA of } \\
\text { lymphocytes }\end{array}$ & $\begin{array}{c}\text { RNA of } \\
\text { lymphocytes }\end{array}$ & $\begin{array}{l}\text { Liver DNA } \\
\text { of rats }\end{array}$ & $\begin{array}{c}\text { DNA of } \\
\text { lymphocytes }\end{array}$ & $\begin{array}{l}\text { Liver DNA } \\
\text { of rats }\end{array}$ \\
\hline Spectral Ra & & & & & \\
\hline $\mathrm{A} 260 / \mathrm{A} 280$ & $1.79 \pm 0.06$ & $2.07 \pm 0.10$ & $1.81 \pm 0.01$ & $1.77 \pm 0.03$ & $1.67 \pm 0.01$ \\
\hline $\mathrm{A} 230 / \mathrm{A} 260$ & $0.44 \pm 0.01$ & $0.49 \pm 0.02$ & $0.47 \pm 0.01$ & $0.42 \pm 0.02$ & $0.46 \pm 0.01$ \\
\hline DNA Yields & $33.3 \pm 4.0^{\mathrm{a}}$ & $24.3 \pm 2.7^{a}$ & $896 \pm 59 b$ & $35.6 \pm 3.7^{a}$ & $909 \pm 34^{b}$ \\
\hline
\end{tabular}

Spectral Ratio

a: DNA or RNA yield per $10^{7}$ cells

b: DNA yield per gram liver tissue

After labeling of normal nucleotides, DNA and RNA nucleotides showed distinct migration rates. (Figure 1). RNA nucleotides migrated slower than DNA. nucleotides. The percentage of each $\mathrm{dNp}$ was near the theoretically expected value (dTp: dC.p: dAp: $d G p=29: 21: 29: 21$ ), which indicates that hydrolysis was efficient and there was no deficit of ATP in the labeling reaction. Since rRNA will comprise most of the isolated ribonucleotides and the base-composition of rRNA in animal cells from various sources are similar, a $\mathrm{Cp}-\mathrm{Gp}$ content of ca. $55 \%$ was expected. Indeed, in this experiment, the Cp-Gp content in total lymphocytic RNA appeared to be $53 \pm 1.1 \%$.

As expected, spectrophotometrically determined DNA concentrations were very well correlated with the DNA concentrations determined by ${ }^{32} \mathrm{P}$-postlabeling, $(\mathrm{r}=0.87, \mathrm{p}<0.01)$. Interestingly, RNA concentrations showed a high correlation as we!! $(r=0.80, p<0.01)$, but the slope of the regression line was only $1 / 4$ of the slope found with DNA. Thus, equal amounts of DNA and RNA determined by means of spectrophotometry, showed a 4-fold difference in the amount of nucleotides if determined by ${ }^{32} \mathrm{P}$-postlabeling (Figure 2). These results suggest that RNA is ca. 4 times less efficiently labeled as compared with DNA. The labeling of RNA was not 
significantly increased by prolonged incubation of RNA-nucleotides with T4-PNK and $\left[\gamma^{32}\right.$ P $]$ ATP for up to 2 hours (data not shown).

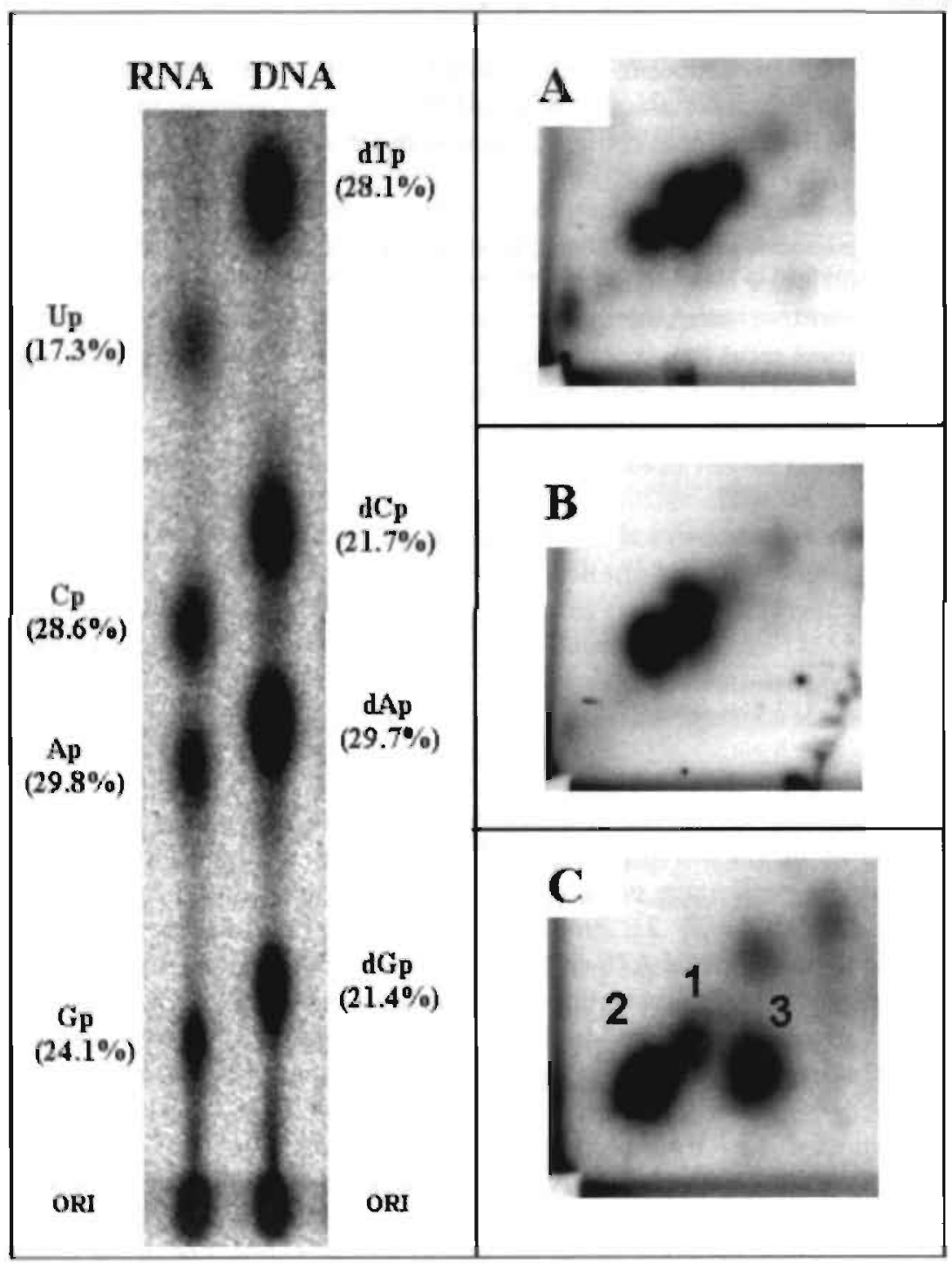

Figure 1. Labeling of normal RNA and DNA nucleotides and adduct profiles in DNA (A) and RNA. (B) of B[a]P treated lymphocytes. Panel C shows DNA adduct spots in rat liver DNA, 11 days after i.p. injection of B[a]P and DNA isolation by the salting out procedure. $\mathrm{ORI}=$ Origin. 


\section{$B P D E-D N A$ adduct recoveries in relation to DNA isolation techniques}

After incubation of lymphocytes with B[a]P for 18 hours, a conjunction of at least three individual spots was found by ${ }^{32} \mathrm{P}$-postlabeling in all samples, of which the in between spot comigrated with a standard adduct formed by $( \pm$ )antibenzo(a)pyrene-diolepoxide (BPDE-DNA) as shown in Figure 1A. These spots could not be resolved and therefore the whole region (all three spots) was used for quantitation purposes and will be further refered to as B[a]P-derived DNA adducts (B[a]P-DNA). B[a]P-DNA adduct levels were analyzed in three independent experiments. In each experiment, three separate incubations of lymphocytes were performed, from which DNA was isolated by both DNA extraction procedures (overall, $n=9$ per isolation procedure). DNA adduct profiles obtained after both DNA isolation procedures showed no qualitative differences, but the B[a]P-DNA adduct spot was quantitatively more intense in the samples that were isolated by the salting out procedure (63.2 \pm 13.7 adducts per $10^{8}$ nucleotides) as compared with the frequently used phenol extraction method $(14.3 \pm 0.8)(\mathrm{P}=0.001)$ (Table II). B[a]P-DNA adduct levels in samples isolated by phenol extraction and subsequent analysis by butanol enrichment were $11.9 \pm 1.9$ adducts per $10^{8}$ nucleotides. In vivo, in rats treated with a single i.p. injection of $\mathrm{B}[\mathrm{a}] \mathrm{P}$, adduct levels were determined in liver DNA by NP1 enriched ${ }^{32}$ P-postlabeling (Table II). Three B[a]P related DNA adducts were detected, one of which comigrated with the BPDE-DNA adlduct standard (Figure 1, panel C, spot\#1). Again, BPDE-DNA adduct levels were higher after salting out procedure as compared with the phenol extraction at all three studied time-points (2 rats per time-point). Two days after the i.p. injection of B[a]P, BPDE-DNA adduct levels were $2.6 \pm 1.0$ and $2.0 \pm 0.8$ adducts per $10^{8}$ nucleotides for respectively salting out and phenol extraction procedures, followed by decreasing adduct levels at $t=4$ days (respectively $1.7 \pm 0.4$ and $1.1 \pm 0.8$ ) and $t=11$ days (respectively $0.9 \pm 0.2$ and $0.3 \pm 0.1$ ). Overall, differences between these isolation methods were statistically significant ( $n=6, P=0.013$, paired statistical analysis by a Wilcoxon signed-rank test). Adduct spot\#2 was also more intense after DNA isolation by salting out $(2.4 \pm 0.5$, $3.6 \pm 1.2$ and $5.3 \pm 0.9$ at respectively $t=2,4$ and 11 days) as compared with phenol extraction (respectively $0.8 \pm 0.4,0.4 \pm 0.2$ and $<$ detectionlimit, overall $\mathrm{P}=0.012$ ). On the other hand, adduct spot\#3 showed a better recovery using phenol extraction $(2.8 \pm 0.9$, $7.0 \pm 2.0$ and $5.1 \pm 0.8$ at respectively $\mathrm{t}=2,4$ and 11 days) as compared with the salting out procedure (respectively $1.6 \pm 0.2,2.6 \pm 0.5$ and $4.4 \pm 0.6$, overall $\mathrm{P}=0.046$ ).

\section{DNA and RNA adducts in lymphocytes, in vitro incubated with B[a]P}

RNA adducts in lymphocytes exposed to B[a]P showed comparable chromatographic characteristics as compared with DNA adducts (Figure 1, panel A and B). DNA adduct levels analyzed by NP1- and butanol-enrichment were similar $\left(14.3 \pm 0.8\right.$ adducts $/ 10^{8}$ nucleotides and $11.9 \pm 1.9$, respectively). Surprisingly using butanol enrichment, the intensity of RNA adduct spots was ca. 12. fold higher as compared to the intensity of the B[a]P-DNA adduct spots, while equal amounts of DNA/RNA were used as determined by spectrophotometry. After correction for the less efficient labeling of RNA nucleotides, RNA adduct levels appeared about 50-fold higher than DNA adduct levels in the same treated cells (both isolated with a 
method based on phenol extraction) using butanol enrichment ( $651 \pm 103$ adducts/ $\left.10^{8}\right)$, but not after NP1- enrichment $(13.3 \pm 7.5)$. Thus, RNA adduct levels decreased dramatically after nuclease P1 treatment; only $2 \%$ of the butanol enriched level was recovered.

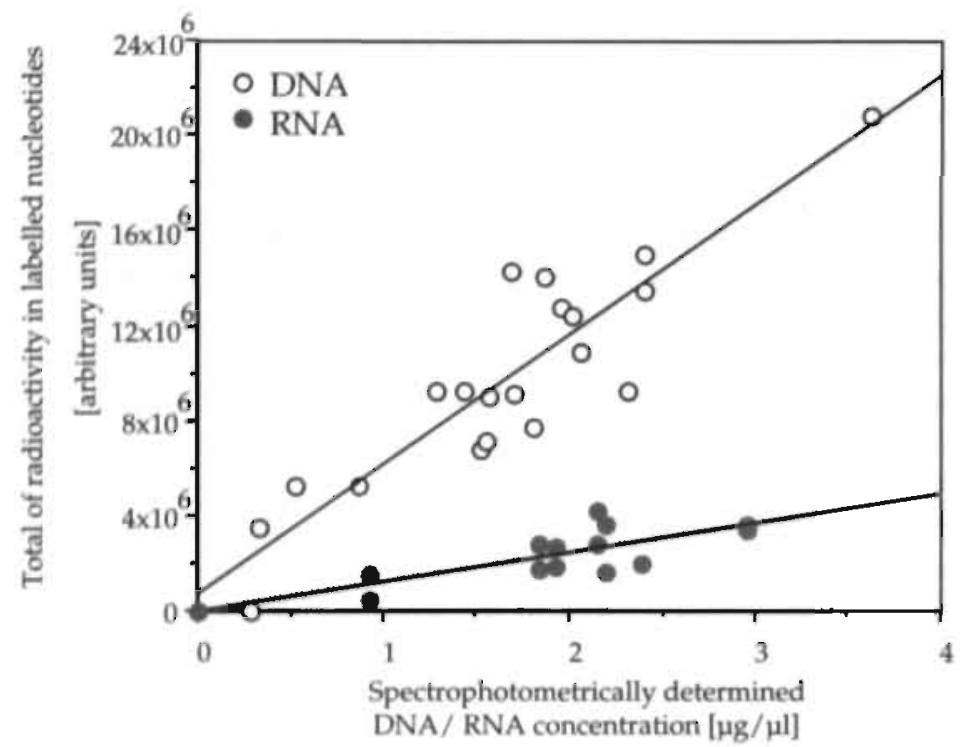

Figure 2. Labeling efficiency of DNA- and RNA-derived nucleotides (slopes: RNA=ca. 1/4 DNA), determined by comparison of spectrophotometrical and labeling analysis, after isolation with methods based on phenol extraction as described in Materials and Methods section.

\section{Discussion}

The results of the present study indicate that differences in DNA isolation methodologies may have implications for the quantitative analysis of carcinogenDNA adducts. Since different laboratories may use divergent techniques to isolate DNA, interlaboratory comparison is jeopardized. In the past, small-scale interlaboratory comparisons have been performed $(17,18)$. In 1992 a larger interlaboratory trial was conducted involving 15 different laboratories (19) and new trials are ongoing. However, these studies did not consider the influence of DNA. isolation procedures since they applied DNA that was already isolated. Various isolation methods are in use, such as phenol extraction, salting out procedures and commercially available kits based on various principles for DNA purification. Furthermore, variations on each of these techniques are likely to occur, which raises the question whether or not adduct recoveries and labeling is affected by these variations. The results of the in vitro experiment showed almost 5-fold differences in adduct recoveries between the two different isolation procedures. This discrepancy could be due to inadequate purification of DNA by the salting out procedure, 
because it has been demonstrated that tetrol-derivates of $\mathrm{B}[\mathrm{a}] \mathrm{P}$ can become ${ }^{32} \mathrm{P}$ labeled in the absence of nucleic acids in in vitro experiments (20). However, labeling of tetrols did not seem to present a problem in analyzing DNA extracted from human or mammalian tissue. In the present study, differences between the two DNA isolation procedures were also present in vivo, although less pronounced (ca. 1.5fold), indicating that the differences between isolation procedures can not completely be explained by insufficient purification from tetrol-derivatives. The results were not consistent for all adduct types and therefore further research is needed to find out what method is best for adduct recoveries after exposure to different complex mixtures. Recently, Brescia et al. (21) used a salting out procedure for DNA isolation from white blood cells and lymphocytes of coke oven workers. In a relevant fraction of DNA samples (54\% and $30 \%$ for WBC and lymphocytes respectively), DNA adducts were detected with similar chromatographic characteristics as compared with their BPDE-modified DNA standard. Unfortunately, no further identification of adducts was attempted.

Table II. DNA and RNA adduct levels after phenol extraction or salting out procedure using either NP1 or Butanol enriched ${ }^{32}$ P-postlabeling after exposure to B[a]P.

\begin{tabular}{|c|c|c|c|c|c|c|}
\hline & $\begin{array}{l}\text { DNA } \\
\text { lymphocytes }\end{array}$ & $\begin{array}{l}\text { RNA } \\
\text { lymphocytes }\end{array}$ & & $\begin{array}{l}\text { Liver DN. } \\
\text { i.p. expose }\end{array}$ & $\begin{array}{l}\text { of rats } \\
\text { to } \mathrm{B}[\mathrm{a}] \mathrm{P}\end{array}$ & \\
\hline $\begin{array}{l}\text { Phenoll } \\
\text { Extraction }\end{array}$ & $\begin{array}{l}14.3 \pm 0.8^{a} \\
11.9 \pm 1.9^{b}\end{array}$ & $\begin{array}{l}13.3 \pm 7.5 a \\
651 \pm 103 b\end{array}$ & $\begin{array}{l}\text { Spot } \\
t=0 \\
t=4 \\
t=11\end{array}$ & $\begin{array}{c}\| 1 \\
2.0 \pm 0.8^{\mathrm{a}} \\
1.1 \pm 0.8 \\
0.3 \pm 0.1\end{array}$ & $\begin{array}{l}\quad \# 2 \\
0.8 \pm 0.4 \\
0.4 \pm 0.2 \\
\text { N.D. }\end{array}$ & $\begin{array}{c}113 \\
2.8 \pm 0.9 \\
7.0 \pm 2.0 \\
5.1 \pm 0.8\end{array}$ \\
\hline $\begin{array}{l}\text { Salting out } \\
\text { Procedure }\end{array}$ & $\begin{array}{l}63.2 \pm 13.7^{\mathrm{a}} \\
\text { N.P. }\end{array}$ & $\begin{array}{l}\text { N.P. } \\
\text { N.P. }\end{array}$ & $\begin{array}{l}t=0 \\
t=4 \\
t=11\end{array}$ & $\begin{array}{l}2.6 \pm 1.0 \\
1.7 \pm 0.4 \\
0.9 \pm 0.2\end{array}$ & $\begin{array}{l}2.4 \pm 0.5 \\
3.6 \pm 1.2 \\
5.3 \pm 0.9\end{array}$ & $\begin{array}{l}1.6 \pm 0.2 \\
2.6 \pm 0.5 \\
4.4 \pm 0.6\end{array}$ \\
\hline
\end{tabular}

a: NP1 enrichment, b: Butanol enrichment

N.P.: Not Performed, N.D.: Not Detected

Thus, if a method of adduct detection is applied that focuses on BPDE-DNA, for example HPLC-FD, the salting out procedure for DNA isolation/purification seems to be the method of choice. Furthermore, in our laboratory, no differences were observed in recoveries of 8-oxo-dG analyzed by HPLC and electrochemical detection using both DNA isolation methodologies (data not shown), but problems with columns may arise using the salting out procedure. Furthermore, the present study suggests that RNA contamination in DNA samples may trouble quantitative analysis in the case butanol enrichment is applied. RNA contamination may result in an overestimation of the actual DNA adduct level, because RNA adducts are labeled as well. In our particular case (lymphocytes incubated with B[a]P), we can calculate that for example $1 \%$ of RNA contamination leads to an overestimation of the DNA adduct level for approximately $10 \%$, assuming that in a mixture of RNA and DNA derived nucleotides, the labeling efficiencies are similar to those found in the 
separate fractions. Low levels of RNA contamination may remain unnoticed, because RNA was ca. 4-fold less efficiently labeled as DNA, which is not unexpected since the ${ }^{32} \mathrm{P}$-postlabeling assay is optimized for DNA, not for RNA. NP1-enriched ${ }^{32} \mathrm{P}$ postlabeling is probably not affected by low RNA contamination, since RNA adducts appeared to be NP1-sensitive. Indeed, Steenwinkel et al. (22) found only marginal effects of RNA contamination on quantitative adduct analysis using NP1 enriched 32P-postlabeling. B[a]P derived RNA adduct levels were higher in in vitro exposed lymphocytes as compared with DNA adduct levels in the same cells. In vivo, similar results were reported by Weyand et al. (23) in rats intratracheally exposed to $\left[{ }^{3} \mathrm{H}\right] \mathrm{B}[\mathrm{a}] \mathrm{P}$. These differences between DNA and RNA adduct levels can be explained by the absence of repair for RNA, the better accessibility of RNA for electrophiles and the differences in location within the cell. Moreover, high RNA adduct levels suggest a possible role for RNA adducts as a an alternative to DNA dosimetry in biomonitoring studies.

In the present study, no information could be obtained regarding adduct formation in mitochondrial DNA (mtDNA) or RNA (mtRNA), which will most probably differ in adduct levels as compared with nuclear DNA or cellular RNA. In previous studies, it was found that covalent binding of $\left[{ }^{3} \mathrm{H}\right] \mathrm{B}[\mathrm{a}] \mathrm{P}$ to mtDNA was 4 to over 500 times greater as compared with nDNA $(24,25)$. Recent studies, using ${ }^{32} \mathrm{P}$ postlabeling for adduct quantitation confirmed these results (26). The two DNA isolation procedures used in this study may give different yields of mitochondrial contaminants (as well as losses in matrix associated DNA), which could partly explain the observed differences in DNA adduct levels. For this reason, several laboratories avoid contamination of nDNA with $(\mathrm{mt}) \mathrm{RNA}$ or mtDNA by starting the DNA extraction with isolated nuclei rather than cells or homogenized tissues. Nonetheless, the isolation procedures as studied in the present work are frequently and routinely applied in most other laboratories, and the results show that a critical evaluation of these techniques is necessary for future research.

In conclusion, differences in DNA isolation methods may partly be responsible for interlaboratory differences. Influences of DNA isolation and purification should be further investigated to obtain the most appropriate method, but it seems impossible to provide a generalized protocol for DNA isolation, since various types of adducts may be recovered differently with specific isolation procedures. RNA contamination in DNA samples may lead to overestimation of adduct levels by butanol enriched ${ }^{32} \mathrm{P}$-postlabeling, whereas adduct analysis after NP1 enrichment is probably less affected.

\section{References}

1. Lewtas, J., Walsh, D., Williams, R., Dobiàs, L. (1997) Air pollution exposure-DNA adduct dosimetry in humans and rodents: evidence for non-linearity at high doses. Mutat. Res, 378, 51-64.

2. Dickey, C., Santella, R.M., Hattis, D., Tang, D., Hsu, Y., Cooper, T., Young, T-L., Perera, F.P. (1997) Variability in PAH-DNA adduct measurements in peripheral mononuclear cells: Implications for quantitative cancer risk assessment. Risk Analysis, 17, 649-656. 
3. Gupta, R.C., Reddy, M.V., Randerath, K. (1982) 32P-Postlabeling analysis of nonradioactive aromatic carcinogen DNA adducts. Carcinogenesis, 3, 1081-1092.

4. Podmore, K., Farmer, P.B., Herbert, K.E., Jones, G.D.D., Martin, E.A. (1997) 32Ppostlabeling approaches for the detection of 8-oxo-2'-deoxyguanosine-3'monophosphate in DNA. Mutat Res, 378, 139-149.

5. Reddy, M.V., Gupta, R.C., Randerath, E., Randerath, K. (1984) ${ }^{32}$ P-postlabeling test for covalent DNA binding of chemicals in vivo: application to a variety of aromatic carcinogens and methylating agents. Carcinogenesis, 5, 231-243.

6. Weinfeld, M., Liuzzi, M., Paterson, M.C. (1990) Response of phage T4 polynuceotide kinase towards dinucleotides containing apurinic sites: designing of a $32 \mathrm{P}$-postlabeling, assay for apurinic sites in DNA. Biochem., 29, 1737-1743.

7. Alexandrov, K., Rojas, M., Geneste, O., Castegnaro, M., Camus, A-M., Petruzelli, S., Giuntini, C., Bartsch, H. (1992). An improved fluorometric assay for dosimetry of benzo[a]pyrene diol epoxide DNA adducts in smokers' lung: comparisons with total bulky adducts and aryl hydrocarbon hydroxylase activity. Cancer Res., 52, 6248-6253.

8. Zeisig, M., Möller, L. (1995) ${ }^{32}$ P-HPLC suitable for characterisation of DNA adducis formed in vitro by polycyclic aromatic hydrocarbons and derivatives. Carcinogenesis, $16,1-9$.

9. Reddy, M.V., Randerath, K. (1986) Nuclease P1-mediated enhancement of sensitivity of 32P-postlabeling test for structurally diverse DNA adducts. Carcinogenesis, 7, 1543 1551.

10. Randerath, K., Randerath, E. (1993) Postlabeling methods- an historical review. In: Phillips, D.H., Castegnaro, M., Bartsch, H. (eds) Postlabeling Methods for detection of DNA adducts. Lyon: International Agency for Research on Cancer (IARC) scientific publications, no 124 pp. 3-9.

11. Gupta, R.C. (1984) Nonrandom binding of carcinogen N-hydroxy-2-acetylaminofluorene to repetitive sequences of rat liver DNA in vivo. Proc. Natl. Acad. Sci., 81, 6934-6947.

12. Miller, S.A., Dykes, D.D., Polesky, H.F. (1988) A simple salting out procedure for extracting DNA from human nucleated cells. Nucleic Acid Res., 16, 1215.

13. Bøyum, A. (1976): Isolation of lymphocytes, granulocytes and macrophages. Scand. I Immunol., 5, 9-15.

14. Chomczynski, P., Sacchi, N. (1987) Single-step method of RNA isolation by acid guanidinium thiocyanate-phenol-chloroform extraction. Anal. Biochem., 161, 156-159.

15. Van Schooten, F.J., Godschalk, R.W.L., Breedijk, A., Maas, L.M., Kriek, E., Sakai, H., Wigbout, G., Baas, P., Van 't Veer, L., Van Zandwijk, N. (1997) 32P-postlabeling of aromatic DNA adducts in white blood cells and alveolar macrophages of smokers: saturation at high exposires. Mut. Res., 378, 65-75.

16. Gallagher, J.E., Jackson, M.A., George, M.H., Lewtas, J., Robertson, L.G.C. (1989) Differences in detection of DNA adducts in the ${ }^{32} \mathrm{P}$-postlabeling assay after either 1 butanol extractionor nuclease P1 treatment. Cancer Lett., 45, 7-12.

17. Hemminki, K., Grzybowska, E., Chorazy, M., Twardowska-Saucha, K., Sroczynski, J.W., Putman, K.L., Randerath, K., Phillips, D.H., Hewer, A., Santella, R.M., Young, T.L., Perera, F.P. (1990) DNA adducts in humans environmentally exposed to aromatic compounds in an industrial area of Poland. Carcinogenesis, 11, 1229-1231.

18. Savela, K., Hemminki, K., Hewer, A., Phillips, D.H., Putman, K.L., Randerath, K. (1989) Interlaboratory comparison of the ${ }^{32} \mathrm{P}$-postlabeling assay for aromatic DNA adducts in white blood cells of iron foundry workers. Mut. Res, 224, 485-492.

19. Phillips, D.H., Castegnaro, M. (1993) Results of an interlaboratory trial of 32Ppostlabeling. In: Phillips, D.H., Castegnaro, M., Bartsch, H. (eds) Postlabeling Methods for detection of DNA adducts. Lyon: International Agency for Research on Cancer (IARC) scientific publications, no 124 pp. 35-49.

20. Masento, M.S., Hewer, A., Grover, P.L., Phillips, D.H. (1989) Enzyme mediated phosphorylation of polycyclic aromatic hydrocarbon metabolites: detection of nonadducted compounds in the ${ }^{32}$ P-postlabeling, assay. Carcinogenesis, 10, 1557-1559. 
21. Brescia, G., Foa, V., Viezzer, C., Celotti, L., Assennato, G. (1997) Aromatic DNA adducts in human peripheral blood lymphocytes and total white blood cells by ${ }^{32} \mathrm{P}-$ postlabeling: need for validation. Biomarkers, 2, 333-339.

22. Steenwinkel, M.J., Roggeband, R., Van Delft, J.H., Baan, R.A. (1993) Improvements in the ${ }^{32} \mathrm{P}$-postlabeling procedure to quantify bulky aromatic DNA adducts. In: Phillips, D.H., Castegnaro, M., Bartsch, H. (eds) Postlabeling Methods for detection of DNA adducts. Lyon: International Agency for Research on Cancer (IARC) scientific publications, no 124 pp. 65-70.

23. Weyand, E.H., Bevan, D.R. (1987) Covalent binding of benzo[a]pyrene to macromolecules in lung and liver of rats following intratracheal instillation. Cancer Lett. 36, 149-159.

24. Allen, J.A., Coombs, M.M. (1980) Covalent binding of polycyclic aromatic compounds to mitochondrial and nuclear DNA. Nature, 287, 244-245.

25. Backer, J.M., Weinstein, I.B. (1980) Mitochondrial DNA is a major target for a dihydrodiol-epoxide derivative of benzo[a]pyrene. Science, 209, 297-299.

26. Balansky, R., Izotti, A., Scatolini, L., D'Agostini, F., De Flora, S. (1996) Induction and chemoprevention of adducts to mitochondrial DNA. Cancer Res., 56, 1642-1647. 


\section{Chapter 12}

\section{Summary and General Discussion}

PAH have been found to be carcinogenic in laboratory animals and are suspected to be carcinogenic in humans (1). To study the association between exposure to $\mathrm{PAH}$ and cancer risk, classic epidemiological techniques can be employed. However, these techniques are usually compromised by the lack of quantitative exposure data and may therefore not be applicable for the assessment of exposure or risk at the individual level. Molecular epidemiology, which aims to integrate techniques of analytical chemistry, biochemistry, molecular biology and epidemiology, has the potential to contribute to cancer research in a number of areas, including assessment of biologically effective exposure to carcinogens and the early identification of individuals at potentially high cancer risk.

Until now, many molecular epidemiological studies have focused on PAHDNA interaction products, i.e., DNA adducts, as measure of exposure to PAH (reviewed in 2,3). However, this field of research is still at an early stage of development at which studies must be considered as small scale 'pilot studies'. Therefore, the validation of DNA adduct measurements needs further attention to improve their applicability in human field studies. Several aspects of DNA adduct formation should be known to optimize study designs and subsequent interpretation of the results (see Chapter 1.6). Some validity criteria for the use of DNA adduct measurements in human exposure monitoring have been studied and presented in this thesis.

Ideally, PAH-DNA adducts should be measured in organs in which PAH might induce cancer, such as human lung or skin. However, samples from these target organs can only be obtained in an invasive manner, and are therefore not useful for routine biomonitoring. In the past, white blood cells (WBC) have been used as surrogate source of exposed DNA, because they can easily be sampled, were found to metabolize PAH to their DNA binding derivatives (4) and provide sufficient amounts of DNA for most methods of DNA adduct analysis. The various subpopulations of WBC (i.e., monocytes, lymphocytes and granulocytes) differ in life-span, as well as metabolizing (5) and repair capacity (6). Therefore, separation of these subsets might be necessary in DNA adduct analysis. Another surrogate source of DNA, used for the analysis of DNA adducts specifically in relation to inhalatory exposure, are the cells obtained by broncho-alveolar lavages (BAL-cells) (7). Previous studies in smoking subjects indicated that BAL-cells or mononuclear blood cells (MNC, i.e., monocytes and lymphocytes) would provide more promising results as compared with total WBC or granulocytes $(7,8)$, but these cell-types were never compared in one single study. Thus, in the present thesis, DNA adduct formation in different WBC-subpopulations and BAL-cells of smokers were compared (Chapter 2) 
to select the most appropriate cell-type for biomonitoring PAH exposure. AromaticDNA adduct levels appeared to be highest in BAL-cells, followed by respectively MNC and granulocytes. These results suggest that DNA adduct measurements in BAL-cells or MNC would provide the most sensitive analysis for assessing exposure to inhaled genotoxic compounds.

The formation of covalent PAH-DNA adducts has been studied in smokers and in occupationally exposed individuals as a quantitative measure of exposure to $\mathrm{PAH}$ (reviewed in 2). Higher DNA adduct levels or a higher proportion of individuals with detectable DNA adduct levels in WBC (subsets) were observed in highly exposed individuals as compared with low/non exposed subjects. In the study presented in Chapter 3 of this thesis, DNA adduct levels in MNC of smokers and aluminum workers also appeared to be related with exposure (exposure to cigarettesmoke or cigarette-tar per day and $\mathrm{PAH}$ in ambient air, respectively), but at high exposure levels saturation of DNA adduct formation was apparent. Several mechanisms that generate non-linearity of the dose-response curves can be involved (9), but the present data do not warrant firm conclusions. Furthermore, it was found that cigarette-smoke may indirectly influence dose-response relationships in WBC of individuals who were additionally exposed via their work environment. It has been reported that smoking cigarettes may enhance adduct formation by other exposures (10), and thus, the shape of the dose-response curve of occupationally exposed smokers might be different as compared with occupationally exposed nonsmokers. Overall, these results seem to indicate that the level of aromatic-DNA adducts in MNC reflects exposure to $\mathrm{PAH}$, but at high exposures non-linearities may occur. In BAL-cells, no relationship between aromatic-DNA adducts and the amount of cigarettes smoked per day was observed. BAL cells are highly and directly exposed to tobacco smoke and therefore, saturation might have occurred at lower numbers of cigarettes smoked per day.

Several studies in smoking subjects indicated that inhalation of PAH might not be the only relevant exposure route for adduct formation in WBC; ingestion or dermal contact with PAH may also be involved (11-13). For a better understanding of data obtained by DNA adduct analysis in humans, it is important to know the contribution of the different exposure routes to DNA adduct formation in different WBC-subpopulations. Therefore, in Chapter 4, exposure route dependent adduct formation by B[a]P was studied in rats acutely exposed to B[a]P via intra-tracheal instillation, gavage and dermal application (since WBC of Lewis-rats consist for more than $95 \%$ of lymphocytes, separation of subpopulations was not performed). Higher adduct levels were observed in WBC after intratracheal and oral exposure of rats as compared with dermal application of B[a]P. In the same rats, similar results were found for lung tissue, which is a major target organ for B[a]P induced carcinogenesis (1). A relation between DNA adduct levels in WBC and lung tissue was found. This relationship was independent from the route of exposure. Initially, in human studies a relationship between DNA adducts in WBC and lung was not observed $(14,15)$, but in a more recent study using $M N C$ instead of total WBC, this relationship was actually found (16). Also in eczema patients topically treated with coal-tar ointments, it was suggested that analysis of total WBC instead of MNC 
would decrease the strenght of the relationship between adduct levels in target tissue (skin) and surrogate tissue (Chapter 7). Overall, these results indicate that DNA adduct formation in MNC might reflect DNA adduct levels in relevant target organs.

To investigate whether DNA adduct measurements have the ability to integrate exposure over a relatively long period of time (a few weeks up to a few months), adduct removal was studied in smokers who stopped smoking for a period of 22 weeks (Chapter 5). DNA adduct levels in MNC were significantly reduced over this period of smoking abstinence, but were still detectable in ca. $60 \%$ of the volunteers as compared with ca. $30 \%$ in a group of never-smokers. The calculated half-life of aromatic-DNA adducts in MNC was approximately 12 weeks, based on logarithmically transformed DNA adduct levels. When a linear model for adduct removal was applied, aromatic-DNA adduct levels in MNC would reach background levels after 25 weeks of smoking cessation. Additionally, DNA adduct formation and removal was studied in separated WBC-subpopulations of individuals topically treated with coal-tar ointments for a short period of time (Chapter 7). After one week of treatment, aromatic-DNA adduct levels were significantly increased in the monocyte, lymphocyte and granulocyte fractions. However, one week after the end of treatment, DNA adduct levels in monocytes and granulocytes were back to base-line levels, whereas in the lymphocyte fraction adduct levels were more persistent. These data indicate that if exposure changes, DNA adduct levels in WBC subpopulations change accordingly. Thus, to study prior exposures to aromatic compounds after a period of non-exposure, the lymphocyte fraction should be used as surrogate tissue. However, if a particular research question focuses on recent exposure only and bias by previous exposures is not wanted, the monocyte fraction could also be of importance.

If exposure is continued, aromatic-DNA adduct levels should remain constant. Until now, however, little information on intra-individual variations in aromaticDNA adduct levels is available (17). In Chapter 3 , intra-individual variation in DNA adduct levels was studied in MNC and BAL-cells from smoking volunteers, by resampling after a period of respectively 2 or 6 months. In MNC of smokers, the intra-individual variation was found to be low over a period of 2 months, but resampling after a period of 6 months resulted in significantly higher DNA adduct levels than in the first sampling of MNC. In this study, the timing of sampling corresponded with a summer and winter period, respectively and it has been described that environmental exposure is higher in winter as compared with summer (18). However, other possible explanations cannot be exciuded, for example, differences in dietary habits between the two sampling periods. In BAL-cells, intraindividual variation in DNA adduct levels over a period of 6 months was found to be low; both samplings were well correlated.

Although DNA adduct levels in MNC correlated with the amount of cigarettes smoked per day, large interindividual variations were observed. This means that DNA adduct levels in two individuals with similar exposure levels can differ significantly. Several sources for interindividual variation were identified in this thesis; genetic polymorphisms in GSTM1 and NAT2 genes that encode for enzymes involved in phase II biotransformation of xenobiotics. (Chapter 5) and body 
composition (Chapter 6). Furthermore, observed variations may, at least partly, be due to differences in DNA repair or induction of DNA repair. In rats acutely exposed to $\mathrm{B}[\mathrm{a}] \mathrm{P}$, increased urinary levels of 8-oxo-dG indicate that nonspecific DNA repair activities were induced (Chapter 9). P53 protein accumulation may be involved in this induction of DNA repair by exposure to $\mathrm{PAH}$, since exposure to $\mathrm{PAH}$ was found to increase P53 levels in human epidermis (Chapter 8), especially in individuals that lack the GSTM1 gene. It is known that P53 is involved in cell-cycle arrest to provide sufficient time for DNA repair. Interindividual differences in adduct formation after PAH exposure are in line with the susceptibility to develop specific cancers, and it can be suggested that DNA adducts can be of use in identifying individuals at high risk (19).

The internal dose of PAH is often assessed by measuring hydroxylated metabolites (e.g., 3-OH-B[a]P and 1-OH-pyrene) in urine of exposed animals and humans (20). These measurements, however, do not represent the biologically effective dose at target tissue level and reflect exposure only over a short period of time. Nonetheless, in rats acutely exposed to B[a]P a relationship between $3-\mathrm{OH}-$ $\mathrm{B}[\mathrm{a}] \mathrm{P}$ excretion and DNA adduct levels in target organs was observed (Chapter 4 and 10). Moreover, in coal-tar treated patients a relationship was found between urinary 3-OH-B[a]P levels and specifically BPDE-DNA adducts (Chapter 7). Overall, 3-OH-B[a]P excretion was significantly increased after exposure to $\mathrm{PAH}$, and reduced to base-line levels within one or two weeks after exposure stopped. DNA adducts, however, were still present in high quantities. These results question the use of urinary metabolites to assess long term exposure to PAH.

In the present thesis, the emphasis was on studies regarding DNA adduct formation after exposure to aromatic compounds of various sources (for example, cigarette smoke or coal tar ointment). In Chapter 10 and 11, several technical aspects of DNA adduct analysis are discussed. When DNA adduct analysis is applied in human biomonitoring studies, the results should be reliable and reproducible with low interassay and interlaboratory variations. The 32.P-postlabeling assay is a routinely and widely used technique, due to its sensitivity and it requires only small amounts of DNA (21). However, specific DNA adducts cannot be identified, and therefore, new techniques were introduced, such as HPLC with fluorescence detection for the detection of specifically BPDE-DNA (Chapter 10) (22). Researchers in the field of molecular epidemiology should be aware of the advantages and disadvantages of each technique for DNA adduct detection, to facilitate their selection of a technique for a particular study.

Overall, it can be concluded that there is sufficient scientific basis to justify the application of DNA adduct measurements in PAH exposure assessment. Furthermore, the results of the present thesis may open doors for new applications of DNA adduct measurements, especially in the field of cancer prevention. For example, DNA adduct measurements can be useful in testing the efficiency of exposure intervention trials. 


\section{References}

1. Hall, M., Grover, P.L. (1990) Polycyclic aromatic hydrocarbons: metabolism, activation and tumour initiation. In: Cooper, C.S., Grover, P.L. (eds) Chemical Carcinogenesis and Mutagenesis, Vol. I, pp 327-372, New York, USA, Raven Press.

2. Schut, H.A.J., Shiverick, K.T. (1992) DNA adducts in humans as dosimeters of exposure to environmental, occupational or dietary genotoxins. FASEB J., 6, 2942-2951.

3. Van Delft, J.H.M., Baan, R. A., Roza, L. (1998) Biological effect markers for exposure to carcinogenic compounds and their relevance for risk assessment. Crit. Rev. Toxicol, 28, 477-510.

4. Gupta, R.C., Earley, K., and Sharma, S. (1988) Use of human lymphocytes to measure DNA binding capacity of chemical carcinogens. Proc. Natl. Acad. Sci., 85, 3513-3517.

5. Okano, P., Miller, H.N., Robinson, R.C., Gelboin, H.V.(1979) Comparison of benzo[a]pyrene and (-)-trans-7,8-dihydroxy-7,8-dihydrobenzo[a]pyrene metabolism in human blood monocytes and lymphocytes. Cancer Res., 39, 3184-3193.

6. Knudsen, L.E., Ryder, L.P., Wasserman, K. (1992) induction of DNA repair synthesis in human monocytes / B-lymphocytes compared with T-lymphocytes after exposure to Nacetoxy- $\mathrm{N}$-acetylaminofluorene and dimethylsulfate in vitro. Carcinogenesis, 13, 12851287.

7. Izzotti, A., G.A. Rossi, M. Bagnasco, S. de Flora (1991) Benzola]pyrene diolepoxideDNA adducts in alveolar macrophages of smokers. Carcinogenesis, 12, 1281-1285.

8. Savela, K., Hemminki, K. (1991) DNA adducts in lymphocytes and granulocytes of smokers and non-smokers detected by ${ }^{32}$ P-postlabeling. Carcinogenesis. 12, 503-508.

9. Lutz, W.K. (1990) Dose-response relationship and low dose extrapolation in chemical carcinogenesis. Carcinogenesis, 11, 1243-1247.

10. Rojas, M., K. Alexandrov, G. Auburtin, A. Wastiaux-Denamur, L. Mayer, B. Mathieu, P. Sebastien and H. Bartsch (1995) Anti-benzo(a)pyrene diolepoxide-DNA adduct levels in peripheral mononuclear cells from coke oven workers and the enhancing effect of smoking. Carcinogenesis, 16, 1373-1376.

11. Rothman, N., Correa-Villasenor, A., Ford, D.P., Poirier, M.C., Haas, R.A., Hansen, J.A., O'Toole, T., Strickland, P.T. (1993) Contribution of occupation and diet to white blood cell PAH DNA adducts in wildland firefighters. Cancer Epidemiol. Biomarkers \& Prev, 2, 341-347.

12. Van Maanen, J.M.S., Moonen, E.J.C., Maas, L.M., Kleinjans, J.C.S., Van Schooten, F.J. (1994) Formation of aromatic DNA adducts inwhite blood cells in relation to urinary excretion of 1-hydroxy-pyrene during consumption of grilled meat. Carcinogenesis, 15, 2263-2268.

13. Paleologo, M., van Schooten, F.J., Pavanello, S., Kriek, E., Zordan, M., Clonfero, E., Brezze, C., Levis, A.G. (1992) Detection of benzo[a]pyrene-diol-epoxide-DNA adducts in white blood cells of psoriatic patients treated with coal tar. Mutat. Res, 281, 11-16.

14. Phillips, D.H., Schoket, B., Hewer, A., Bailey, E., Kostic, S., and Vincze, 1. (1990) Influence of cigarette smoking on the levels of DNA adducts in human bronchial epithelium and white blood cells. Int. I. Cancer, 46, 569-575.

15. Van Schooten, F.J., Hillebrand, M.j.X., Van Leeuwen, F.E., Van Zandwijk, N., Jansen, H.M., Den Engelse, L., and Kriek, E. (1992) Polycyclic aromatic hydrocarbon-DNA adducts in white blood cells from lung cancer patients: no correlation with adduct levels in lung. Carcinogenesis, 13, 987-993.

16. Wiencke, J.K., K.T. Kelsey, A. Varkonyi, K. Semey, J.C. Wain, E. Mark and D.C. Christiani (1995) Correlation of DNA adducts in blood mononuclear cells with tobacco carcinogen-induced damage in human lung. Cancer Res., 55, 49104914.

17. Dickey, C., Santella, R.M., Hattis, D., Tang, D., Hsu, Y., Cooper, T., Young, T.L., Perera, F.P. (1997) Variability in PAH-DNA adduct measurements in peripheral mononuciear cells: implications for quantitative cancer risk assessment. Risk Analysis, 17, 649-656.

18. Grzybowska, E., K. Hemminki, J. Szeliga and M. Chorázy (1993) Seasonal variation of aromatic DNA adducts in human lymphocytes and granulocytes. Carcinogenesis, 14, 2523-2526. 
19. Tang, D., Santella, R.M., Blackwood, A.M., Young, T.-L., Mayer, J., Jaretzki, A., Grantham, S., Tsai, W.-Y., Perera, F.P. (1995) A molecular epidemiological case-control study of lung cancer. Cancer Epidemiol. Biomarkers \& Prev. 4, 341-346.

20. Strickland, P., Kang, D., Sithisarankul, P. (1996) Polycyclic aromatic hydrocarbon metabolites in urine as biomarkers of exposure and effect. Environ. Health Perspect., 104, Suppl. 5, 927-932.

21. Reddy, MLV., Randerath, K.(1986) Nuclease P1 mediated enhancement of sensitivity of ${ }^{32} \mathrm{P}$-postlabeling test for structually diverse DNA-adducts. Carcinogenesis, 7, $1543-$ 1551 .

22. Alexandrov, K., Rojas, M., Geneste, O., Castegnaro, M., Camus, A-M., Petruzzelli, S., Giuntini, C. and Bartsch, H. (1992) An Improved fluorometric assay for dosimetry of benzo(a)pyrene diol epoxide DNA adducts in smokers' lung: comparisons with total bulky adducts and aryl hydrocarbon hydroxylase activity, Cancer Res., 52, 6248-6253. 


\section{Samenvatting}

Polycyclische aromatische koolwaterstoffen (PAK) vormen een groep van verbindingen, die ontstaan als gevolg van onvolledige verbranding van organisch materiaal. Veel PAK blijken kankerverwekkend te zijn in proefdieren en er wordt verondersteld dat ze ook kankerverwekkend kunnen zijn in mensen. Bepaalde vormen van kanker komen namelijk vaker voor in mensen die beroepsmatig werden blootgesteld aan PAK, dan onder de gehele bevolking. PAK zijn in staat kanker te veroorzaken doordat ze in het lichaam omgezet worden tot reactieve producten, welke kunnen reageren met het erfelijk materiaal (DNA) in de cel, waardoor zgn. PAK-DNA addukten worden gevormd. Deze DNA addukten kunnen vervolgens leiden tot DNA mutaties, die de normale processen van celgroei ontregelen. Door deze verstoring van de celgroei kan het proces dat uiteindelijk leidt tot kanker geïnitieerd worden.

De gemiddelde bevolking kan op drie manieren worden blootgesteld aan PAK, te weten oraal (bv. verontreinigde voeding), inhalatoir (bv. sigarettenrook) en dermaal (bv. koolteer houdende zalven). De kankerepidemiologie heeft behoefte aan gevoelige methoden voor de bepaling van deze blootstelling aan PAK en de hieruit voortvloeiende verhoogde kans op kanker. Bepaling van de hoeveelheid PAK-DNA addukten in lichaamscellen zou voor dit doel een ideale maat kunnen zijn, aangezien DNA addukten een indruk geven van de "biologisch effectieve dosis". Dit is de hoeveelheid geactiveerde PAK dat uiteindelijk wordt gebonden aan DNA. Organen waarin PAK kanker zouden kunnen veroorzaken (bv. long) zijn echter niet bereikbaar voor routinematig onderzoek en dus moet er gezocht worden naar andere geschikte bronnen van DNA. Het meest gebruikte 'surrogaat' weefsel wordt gevormd door makkelijk te bereiken witte bloed cellen (WBC). WBC kunnen worden onderverdeeld in een aantal subpopulaties, namelijk monocyten, lymfocyten en granulocyten. Een andere belangrijke bron van blootgestelde cellen wordt gevormd door cellen verkregen uit de long door middel van een longspoeling (bronchoalveolaire lavage; BAL-cellen). Echter, voordat DNA addukten in WBCsubpopulaties of BAL-cellen doeltreffend kunnen worden toegepast in het vaststellen van blootstelling aan PAK, dienen een aantal aspecten van DNA addukt vorming in deze cellen bekend te zijn:

In hoofdstuk 2 van dit proefschrift werden DNA addukt niveaus in verschillende WBC-subpopulaties en BAL-cellen van rokers bestudeerd, om vast te stellen welke cel-typen het meest geschikt zouden kunnen zijn om de mate van blootstelling aan PAK via sigarettenrook te bepalen. Aromatische-DNA addukt niveaus bleken het hoogst te zijn in BAL-cellen, gevolgd door respectievelijk mononucleaire bloedcellen (MNC, dit zijn monocyten plus lymfocyten) en granulocyten. Deze resultaten geven aan dat de bepaling van DNA addukten in BAL-cellen of MNC mogelijk de meest gevoelige analyses zijn om blootstelling aan aromatische verbindingen vast te stellen. Verder bleken de DNA addukt niveaus in MNC gerelateerd te zijn aan de mate van blootstelling; hoe meer iemand is blootgesteld, des te hoger is het DNA addukt niveau. Bij zeer hoge blootstellingen daarentegen, bleken de DNA addukt niveaus verhoudingsgewijs niet verder te 
steigen (Hoofdstuk 3). Een relatie tussen het aantal sigaretten dat per dag gerookt werd en het DNA addukt niveau in BAL-cellen werd niet aangetoond. Dit zou verklaard kunnen worden door het feit dat BAL-cellen direct en sterk zijn blootgesteld aan geïnhaleerde carcinogenen, waardoor een verzadiging van de DNA addukt vorming eerder kan optreden dan in het perifere bloed.

Inhalatie van PAK via bv. sigarettenrook is niet de enige route waarlangs PAK het lichaam kunnen binnendringen en waarna DNA addukten in WBC gevormd kunnen worden. Vandaar dat in hoofdstuk 4 in proefdieren (ratten) werd onderzocht, welke invloed verschillende blootstellings-routes kunnen hebben op de DNA addukt vorming in WBC door benzo(a)pyreen (B[a]P, een belangrijke carcinogene PAK). De hoogste DNA addukt niveaus in WBC werden gevonden na orale en intra-tracheale blootstelling, terwijl de laagste DNA addukt niveaus werden gevonden na dermale toediening van B[a]P. DNA addukt niveaus in WBC waren gerelateerd aan die in de long, en deze relatie was onafhankelijk van de blootstellingsroute. Over het algemeen werden statistisch significante relaties waargenomen tussen DNA addukt niveaus in WBC en relevante doelwitorganen (die organen waarin PAK kanker kunnen induceren). Ook in eczeem patienten, die dermaal behandeld werden met koolteer zalven, waarin hoge concentraties PAK voorkomen, werd een relatie aangetoond tussen het DNA addukt niveau in MNC en de huid (hoofdstuk 7). De resultaten van deze studies met zowel proefdieren als patienten, geven aan dat DNA addukten in MNC gebruikt kunnen worden als maat voor de hoeveelheid DNA schade in relevante doelwitorganen.

Om te bestuderen of DNA addukt metingen de mogelijkheid bieden om blootstelling over een relatief lange periode vast te stellen (weken tot maanden), werd de DNA addukt verwijdering bestudeerd in MNC van vrijwilligers die stopten met roken voor een periode van tenminste 22 weken (Hoofdstuk 5). Na het stoppen met roken waren de DNA addukt niveaus duidelijk gedaald, maar waren nog steeds aantoonbaar in $60 \%$ van de vrijwilligers. Ter vergelijking werd ook de aanwezigheid van DNA addukten bestudeerd in MNC van een groep vrijwilligers die nog nooit gerookt hadden. In deze personen werden in slechts $30 \%$ van de personen DNA addukten gedetecteerd. De halfwaardetijd (de tijd waarin het addukt niveau is gehalveerd) in MNC werd geschat op circa 12 weken. DNA addukt vermindering werd ook bestudeerd in WBC-subpopulaties van de eczeem patienten behandeld met koolteer zalf (hoofdstuk 7). De aanwezigheid van DNA addukten in de monocyten en granulocyten fractie bleek veel korter te zijn dan die in de lymfocyten fractie. Dit komt goed overeen met de levensduur van deze celtypes. DNA addukt metingen in lymfocyten zijn dus geschikt om langdurige blootstelling aan PAK vast te stellen, of om PAK belasting vast te stellen na een periode waarin geen verdere blootstelling plaatsvond. DNA addukten in monocyten kunnen mogelijk gebruikt worden bij het vaststellen van blootstelling over een korte periode, zonder verstoring van de resultaten door blootstellingen die verder in het verleden plaatsvonden. Deze resultaten geven aan dat een verlaging van de blootstelling aan PAK, gepaard gaat met een daling van het DNA adduct niveau in WBCsubpopulaties. 
Dit houdt ook in dat indien de blootstelling gelijk blijft, het adduct niveau niet zou mogen veranderen. Tot nu toe zijn er weinig studies beschikbaar die ingaan op dit aspect (binnenpersoons of intraindividuele variatie). In hoofdstuk 3 wordt een studie beschreven waarin de intraindividuele variatie werd bestudeerd door herhaaldelijke metingen van DNA addukten in MNC en BAL-cellen van rokers over een periode van 2 tot 6 maanden. In MNC van deze rokers bleek de intraindividuele variatie klein te zijn over een periode van 2 maanden. Echter, na een half jaar bleken de DNA addukt niveaus in dezelfde personen te zijn verhoogd, terwijl ze niet meer of minder waren gaan roken. Een mogelijke verklaring voor deze waarneming is dat in de winterperiode ( $2^{\circ}$ meting), hogere PAK-concentraties gemeten worden in de buitenlucht dan in de zomer ( 1 meting). Andere mogelijke verklaringen kunnen echter niet worden uitgesloten. De intraindividuele variatie in BAL-cellen was klein over een periode van 6 maanden; beide metingen in BAL-cellen bleken goed met elkaar overeen te stemmen.

Hoewiel DNA addukten in MNC goed correleerden met het aantal sigaretten dat dagelijks geconsumeerd werd, werden er toch grote interindividuele variaties (tussenpersoons variatie) waargenomen. Dat wil zeggen dat twee personen met een gelijk rookgedrag, toch verschiliende DNA addukt niveaus in MNC kunnen hebben. Verschillende mogelijke bronnen voor deze variatie werden in dit proefschrift verder bestudeerd. Eén mogelijke bron voor deze interindividuele variatie is de natuurlijke genetische variatie in genen welke coderen voor enzymen die carcinogenen kunnen detoxificeren. Rokers met het GSTM1(-/-) en/of het NAT2 langzame acetyleerders genotype hadden hogere DNA addukt niveaus in hun MNC dan rokers met het GSTM1(+) en/of het NAT2 snelle acetyleerders genotype (hoofdstuk 5). Ook de lichaamssamenstelling van rokers zou een rol kunnen spelen in variaties in DNA addukt niveaus tussen personen met een ogenschijnlijk gelijke blootstelling (hoofdstuk 6). Rokers met een hoge 'body mass index' (BMI, dit is gewicht/lengte ${ }^{2}$ ) hadden een lager DNA adduct niveau dan rokers met een lage BMI. Als laatste werden DNA herstel activiteiten of de inductie hiervan bestudeerd als bron van variatie in DNA addukt niveau (hoofdstuk 9). Het eiwit P53 kan hierbij een belangrijke rol spelen, omdat blootstelling aan PAK de concentraties van dit. eiwit in epidermale cellen doet stijgen. Van P53 is bekend dat het de celdeling remt, waardoor de cellen voldoende tijd krijgen om adequat te reageren op de schade die is aangericht door carcinogenen.

In beroepsmatig blootgestelde individuen wordt de interne dosis van PAK vaak vastgesteld door middel van metingen van PAK-metabolieten in urine (bijv. 3hydroxy-benzo[a]pyreen en/of 1-hydroxy-pyreen). Deze metingen zijn echter niet representatief voor de biologisch effectieve dosis en geeft de blootstelling aan PAK over een slechts korte periode weer. Desalniettemin, werden goede correlaties waargenomen tussen de 3-hydroxy-B[alP uitscheiding in de urine en de DNA addukt vorming in doelwit organen van ratten die acuut werden blootgesteld aan $\mathrm{B}[\mathrm{a}] \mathrm{P}$. In dit experiment valt op dat de 3-hydroxy-B[a]P concentraties in de urine en het DNA addukt niveau kort na de acute blootstelling verhoogd zijn. Binnen één à twee weken is de 3-hydroxy-B[a]P' concentratie weer terug op basis niveau, terwij] DNA addukten nog in grote hoeveelheden in de organen gevonden kunnen worden. 
In patienten behandeld met koolteer zalven werd een vergelijkbare relatie waargenomen tussen 3-hydroxy-B[a] $\mathrm{P}$ in de urine en een specifiek addukt gevormd door B[a]P.

De nadruk van dit proefschrift ligt op DNA addukt bepalingen na blootstelling aan aromatische verbindingen. Indien DNA addukten inderdaad worden toegepast in het vaststellen van PAK-blootstelling, dan moeten de resultaten van deze metingen en de technieken waarmee deze verkregen worden, betrouwbaar en reproduceerbaar zijn. De "P-postlabeling methode is een veelvuldig toegepaste techniek met een zeer grote gevoeligheid, en waarmee addukten kunnen worden aangetoond in slechts kleine hoeveelheden DNA. Helaas is deze techniek niet in staat om addukten te identificeren en daarom werden nieuwe technieken geintroduceerd zoals een HPLC-fluorescentie methode (hoofdstuk 10). Met deze techniek kunnen specifieke B[a]P gerelateerde DNA addukten gedetecteerd worden. Onderzoekers in de moleculaire epidemiologie dienen er zich van bewust te zijn dat elke techniek haar eigen voor- en nadelen heeft, opdat een juiste keuze gemaakt kan worden voor de toepassing van een bepaalde techniek in een experiment of studie.

In het algemeen kan geconcludeerd worden dat er voldoende wetenschappelijke basis is om DNA addukt metingen toe te passen in het vaststellen van de biologisch effectieve dosis na blootstelling aan PAK. Verder kunnen de resultaten van dit proefschrift als basis dienen voor nieuwe toepassingen van DNA addukt metingen, bijvoorbeeld op het gebied van kanker (chemo)preventie. 


\section{Dankwoord}

"In de wetenschap gaat het om feiten, niet om personen."
(Marie Curie)

Het verrichten van wetenschappelijk onderzoek als assistent in opleiding is tot op zekere hoogte goed te vergelijken met de sport gewichtheffen; in principe is het een individuele taak, maar zonder de hulp van anderen zul je er nooit in slagen om deze zware last te tillen.

Mijn coach en co-promoter, Frederik-Jan van Schooten, wil ik als eerste bedanken voor zijn directe begeleiding. Zijn deur stond altijd voor mij open om van gedachte te wisselen over het onderzoek, ook als hij het eigenlijk te druk had met andere zaken. Frederik-Jan introduceerde me op een fantastische wijze in het 'postlabel' wereldje, en hij heeft mijn enthousiasme gewekt voor de genetische toxicologie en moleculaire epiderniologie. Bedankt voor alles.

Tegenwoordig nemen veel topsporters een manager in de arm, zodat hun loopbaankansen optimaal benut kunnen worden. Ik wil mijn manager en promotor Jos Kleinjans bedanken voor de kritische en verbazingwekkend snelle manier waarop hij mijn manuscripten heeft doorgenomen. Verder wil ik hem bedanken voor zijn inzet bij mijn zoektocht naar een nieuwe baan. Ich danke Ihnen herzlich aus Heidelberg.

Voor een gewichtheffer is naast kracht en doorzettingsvermogen, ook techniek een belangrijke eigenschap om gewichten boven het hoofd te tillen. De postlabeling techniek heb ik geleerd van 'post'Lou'beling' Maas (mijn eerste trainer). Question to Lou: What would you do when you arrive in hell? Answer: Postlabeling !. Bedankt voor je fantastische gevoel voor humor.

Ook een aantal stagiaires mag ik niet vergeten. Alinda, Dorien, Mariëlle, Wendy en Karlijn hebben hun (deel)gewichtjes getild en hebben op deze wijze voor een belangrijk deel ertoe bijgedragen dat de last voor mij minder zwaar was en dat dit proefschrift uiteindelijk tot stand gekomen is. Bedankt meiden.

Mijn trainingspartners en mede-AlO's: Ingrid (vrouwtje van) Vermeer, razende Roel Schins, Ad(hesie) Knaapen, Hamid, Zhai, Soedja, Rob Stierum en Harald Moonen. Bedankt voor de leuke momenten en de samenwerking.

Een aantal medewerkers van GRAT hebben mij bijgestaan bij het afronden van enkele experimenten; 'Pip'edwin Moonen, Pauline Schilderman (de schrik van alle proefdieren), Harma Albering, Irene Welle, Marcel 'badmuts' van Herwijnen, Danielle Pachen en 'nestor' Ebienus van Agen. Bedankt voor jullie steun in de rug en enthousiasme voor mijn onderzoek. Keep in touch! Alle andere (ex)medewerkers van capaciteitsgroep GRAT wil ik natuurlijk ook bedanken voor de leuke samenwerking en de gezellige tijd.

Ik mag ook nog een aantal personen van andere afdelingen en instituten niet overslaan: Judith Ostertag (Dermatologie, AzM), Nico van Zandwijk (NKI, Amsterdam), Jan Verhaert (St. Barbara Hospitaal, België) en Henny van Straaten (Anatomie en Embryologie, UM). Bedankt voor jullie inzet en hulp. 
Als laatste wil ik mijn vriendin, Bettina, nog bedanken voor haar geduld en steun. Bettina, je had gelijk: " Na regen komt Heidelberg."

Bedankt allemaal,

Roger 


\section{Curriculum vitae}

Roger Wilhelmus Laurentius Godschalk werd geboren op 7 oktober 1971 te Heerlen. Na het behalen van het VWO diploma aan het Sancta Maria College te Kerkrade-West in 1990, begon hij zijn studie Gezondheidswetenschappen met als afstudeerrichting. Biologische Gezondheidkunde aan de Rijksuniversiteit Limburg (tegenwoordig Universiteit Maastricht) te Maastricht. Deze studie sloot hij in december 1994 met cum laude af. Vanaf februari 1995 was hij werkzaam als assistent in opleiding bij de capaciteitsgroep Gezondheidsrisico Analyse en Toxicologie van de Universiteit Maastricht, alwaar het onderzoek beschreven in dit proefschrift werd uitgevoerd. Tijdens deze periode voltooide hij tevens de toxicologie cursussen: "Principes en mechanismen" en "Effecten en toepassingen" aan de Open Universiteit te Heerlen. Vanaf juli 1999 is Roger werkzaam als wetenschappelijk medewerker bij de afdeling 'Cancer risk factors and toxicology' van het Deutsche Krebs Forschungs: Zentrum (DKFZ) te Heidelberg in Duitsland.

\section{List of publications}

\section{Articles}

Van Schooten F.J., Godschalk R. (1996) Coal-tar therapy, Is it carcinogenic? Drug Safety, 15(6): 374-377.

Van Schooten F.J., Godschalk R.W.L., Breedijk A., Maas L.M., Kriek E., Sakai H., Wigbout G., Baas P., Van 't Veer L., Van zandwijk N. (1997) ${ }^{32}$ P-postlabeling of aromatic DNA adducts in white blood cells and alveolar macrophages of smokers; saturation at high exposures. Mutation Research, 378: 65-75.

Godschalk R.W.L., Vermeer I.T.M., Kriek E., Floot B., Schilderman P.A.E.L., Moonen E.J.C., Kleinjans J.C.S., Van Schooten F.J. (1997) Comparison of 32P-postlabeling and HPLC-FD analysis of DNA adducts in rats acutely exposed to benzo[a]pyrene. Chemico-Biological Interactions, 104: 41-54.

Borm P.J.A., Knaapen A.M., Schins R.P.F., Godschalk R.W.L., Van Schooten F.J. (1997), Neutrophils amplify the formation of DNA adducts by benzo[a]pyrene in lung target cells. Environmental Health Perspectives, 105 (Suppl. 5): 1089-1093.

Godschalk R.W.L., Maas L.M., Van Zandwijk N., Van 't Veer L.J., Borm P.J.A., Verhaert J., Kleinjans J.C.S., Van Schooten F.I. (1998) Differences in aromatic DNA adduct levels between alveolar macrophages and subpopulations of white blood cells from smokers. Carcinogenesis, 19(5): 819-825.

Godschalk R.W.L., Ostertag J.U., Moonen E.J.C., Neuman H.A.M., Kleinjans J.C.S., Van Schooten F.J. (1998) Aromatic DNA adducts in human white blood cells and skin after dermal application of coal tar. Cancer Epidemiology, Biomarkers \& Prevention, 7: 767773.

Godschalk R.W.L., Maas L.M., Kleinjans J.C.S., Van Schooten F.J. (1998) Influences of DNA isolation and RNA contamination on carcinogen DNA adduct analysis by ${ }^{32} \mathrm{P}-$ postlabeling. Environmental and Molecular Mutagenesis, 32, 344-350. 
Godschalk R.W.L., Ostertag J.U., Zandsteeg A., Van Agen B., Neuman H.A.M., Van Straaten H., Van Schooten F.J. Formation of aromatic DNA adducts and P53 accumulation in human skin and lymphocytes. Submitted to Journal of the National Cancer Institute (JNCI).

Godschalk R.W.L., Maas L.M., Van Agen B., Moonen, E.J.C., Pachen, D., Van Zandwijk N., Van Schooten F.J. Genetic polymorphisms of GSTM1 and NAT2 in relation to DNA and protein adducts in smoking subjects. Submitted to Cancer Epidemiology, Biomarkers and Prevention.

Godschalk R.W.L., Moonen E.J.C., Schilderman P.A.E.L., Kleinjans J.C.S., Van Schooten F.J. Exposure route dependent formation of DNA adducts by polycyclic aromatic hydrocarbons. Submitted to Carcinogenesis.

Godschalk, R.W.L., Schilderman, P.A.E.L., Van Agen, E., Broekmans, W.M.R., Van Schooten, F.J., Kleinjans, J.C.S. Repair of oxidative DNA damage after acute oral exposure to benzo[a]pyrene. Submitted as short communication to Cancer Research

Godschaỉk, R.W.L., Feldker, D.E.M., Borm, P.J.A., Wouters, E.F.M., Van Schooten, F.J. DNA- and protein-adduct removal from blood cells of smokers after smoking cessation. Submitted to Cancer Epidemiology, Biomarkers \& Prevention.

Besarati Nia, A., Van Straaten, H.M.W, Godschalk, R.W.L., Vam Zandwijk, N., Balm, F., Kleinjans, J.C.S., Van Schooten, F.J. Quantitative immunoperoxidase detection of PAH-DNA adducts in mouth floor and buccal mucosa cells of smokers and nonsmokers. Submitted to Cancer Epidemiology, Biomarkers and Prevention.

\section{Abstracts}

Borm P., Godschalk R., Schins R., Zwingmann I., Van Schooten F.J. (1995) Granulocyte mediated effects on B[a]P-DNA adducts and cytokine release in lung target cells. 5th European Meeting of Environmental Hygiene, Prague, Int. J. Hyg. Environ. Med., 198: $3-4$.

Borm P.J.A., Godschalk R.W.L., Knaapen A.M., Zwingmann I.H., Schins R.P.F., Driscoll K.E. (1996) Neutrophils amplify benzo(a)pyrene adduct fornation in alveolar epithelial cells. American Thoracic Society, May 11-15, New Orleans, USA, Am. J. Respir. Crit. Care. Med, 153(4): A511

- Godschalk R.W.L., Vermeer I.T.M., Schilderman P.A.E.L., Moonen E.J.C., Kleinjans J.C.S., Van Schooten F.J. (1996) The use of white blood cell DNA adducts in biologically effective dose monitoring of polycyclic aromatic hydrocarbons. 25th Annual meeting of the European Environmental Mutagen Society, June 13-18, Noordwijkerhout, The Netherlands, Mutation Research, 360: 201.

Knaapen A.M., Schins R.P.F., Godschalk R.W.L., Borm P.J.A (1996) DNA adducts and oxidative damage in lung epithelial cells coincubated with neutrophils and benzo[a]pyrene. 6th International meeting on toxicology of natural and man-made fibrous and non-fibrous particles, September 15-18, Lake Placid, USA.

- Godschalk R.W.L., Kleinjans J.C.S., Van Schooten F.J. (1996) DNA adducts in white blood cells upon exposure to polycyclic aromatic hydrocarbons. 3rd symposium for Ph.D students in toxicology, November 14-15, Doorwerth, The Netherlands.

Godschalk R.W.L., Van Agen B., Welle I., Kleinjans J.C.S., Van Schooten F.J. (1997) Benzo[a]pyrene-diol-epoxide induced DNA adduct levels correlate with P53 
expression in human lymphocytes. Annual Meeting of the Dutch Society for Toxicology, Januari 9, Utrecht, The Netherlands.

Godschalk, R.W.L., Kleinjans, J.C.S., Van Schooten, F.J. (1997) ${ }^{32}$ P-postlabeling of DNA and RINA adducts in white blood cells. 88th Annual Meeting of the American Association for Cancer Research, April 12-16, San Diego, USA.

Van Zandijk, N., Maas, L.M., Breedijk, A., Godschalk R.W.L., Sakai, H., Wigbout G., Baas P., Van 't Veer L.J., Van Agen B., Kleinjans J.C.S., Van Schooten F.J. (1997) Aromatic DNA adduct levels in alveolar macrophages and lymphocytes of smoking volunteers; effects of $\mathrm{N}$-acetylcystein (NAC) supplementation. 88th Annual Meeting of the American Association for Cancer Research, April 12-16, San Diego, USA.

Van Zandijk, N., Maas, L.M., Breedijk, A., Godschalk R.W.L., Sakai, H., Wigbout G., Baas P., Van 't Veer L.J., Van Agen B., Kleinjans J.C.S., Van Schooten, F.J (1997) Aromatic DNA adduct levels in alveolar macrophages and lymphocytes of smoking volunteers; effects of $\mathrm{N}$-acetylcystein (NAC) supplementation. 8th World Conference on lung cancer. August 10-15, Dublin, Ireland.

Godschalk, R.W.L., Ostertag, J.U., Zandsteeg, A.M.G., Van Agen, E., Neuman, H.A.M., Van Straaten, H., Van Schooten, F.J. (1999) Impact of GSTM1 on DNA adducts and p53 accumulation in human skin and lymphocytes. 90th Annual Meeting of the American Association for cancer Research, April 11-15, Philadelphia, U.S.A.

Godschalk, R.W.L., Broekmans, W.M.R., Schilderman, P.A.E.L., Maas, L.M., Kleinjans, J.C.S., Van Schooten, F.J. (1999) Influence of different exposure routes on DNA adduct formation of polycyclic aromatic hydrocarbons. 90th Annual Meeting of the American Association for cancer Research, April 11-15, Philadelphia, U.S.A., Oral presentation.

Besarati Nia, A., Van Straaten, H.M.W., Godschalk, R.W.L., Van Zandwijk N., Balm, F., Kleinjans, J.C.S., Van Schooten, F.J. (1999) Quantitative immunoperoxidase detection of smoking induced DNA adducts in mouth floor cells and buccal mucosa of smokers. 90th Annual Meeting of the American Association for cancer Research, April 11-15, Philadelphia, U.S.A. 


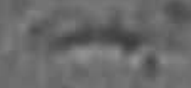

,

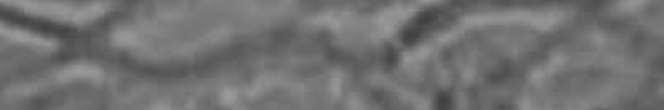

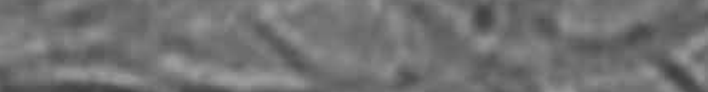

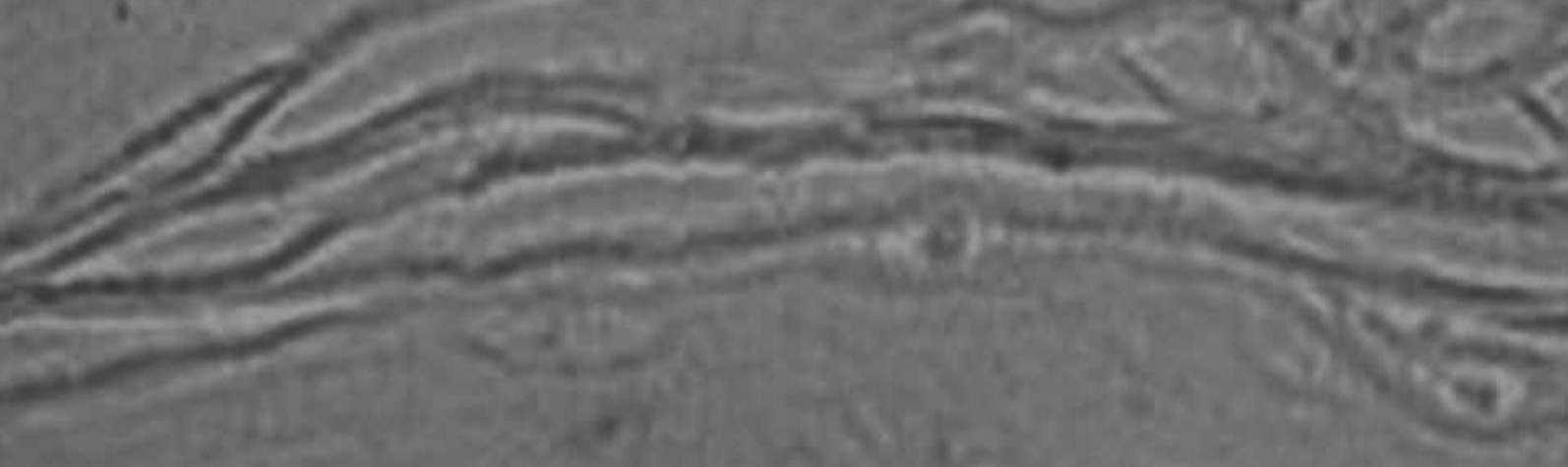

$+$

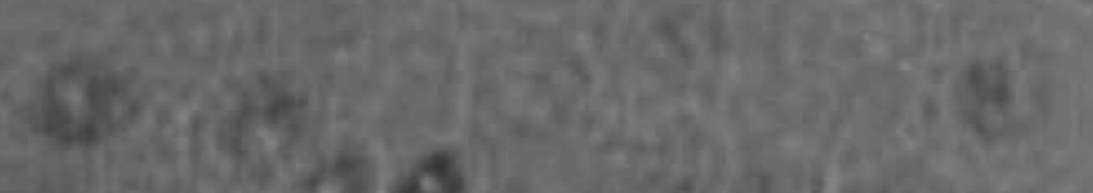

(9)

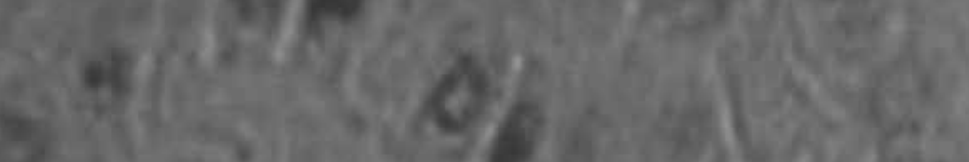

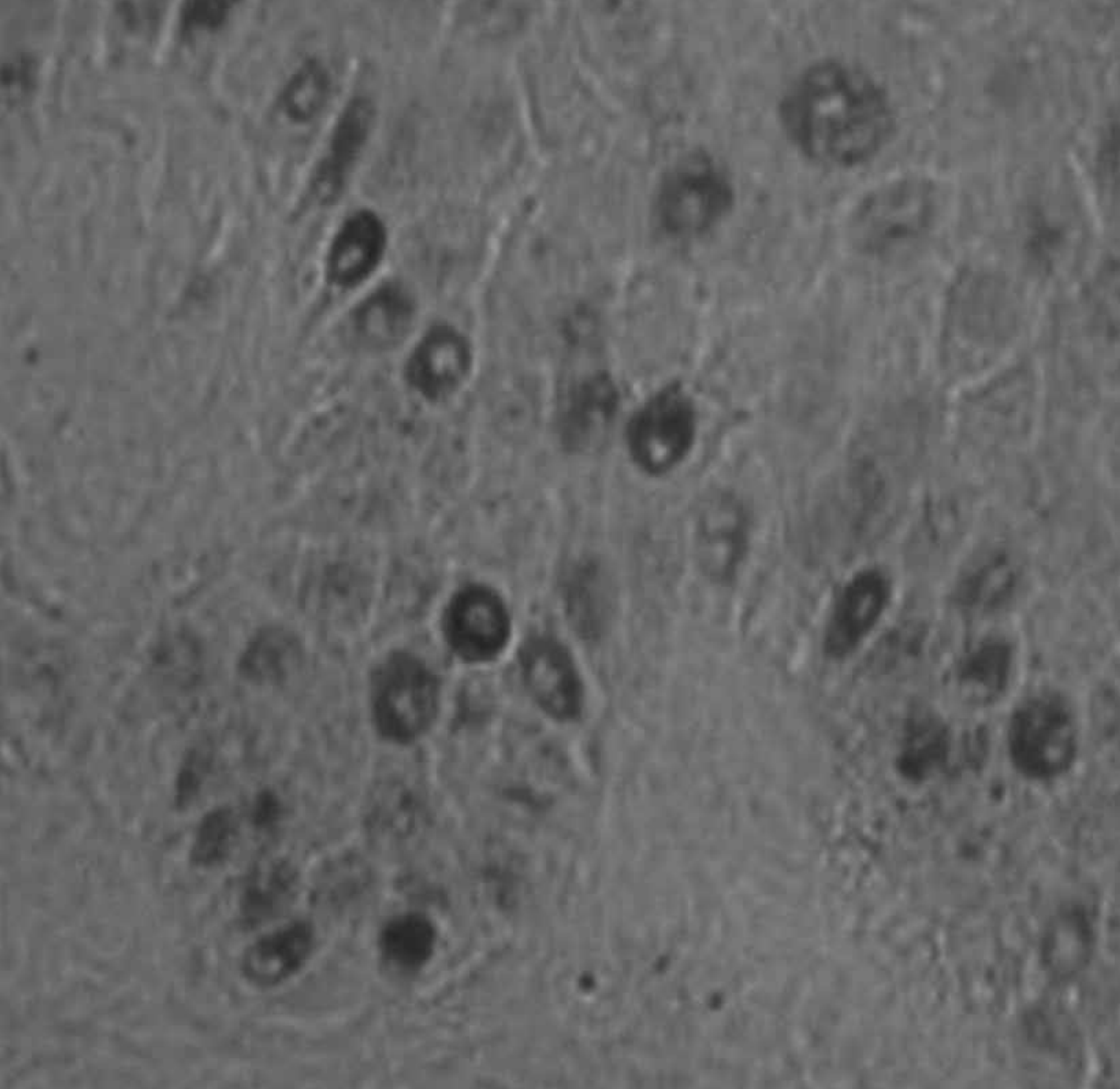

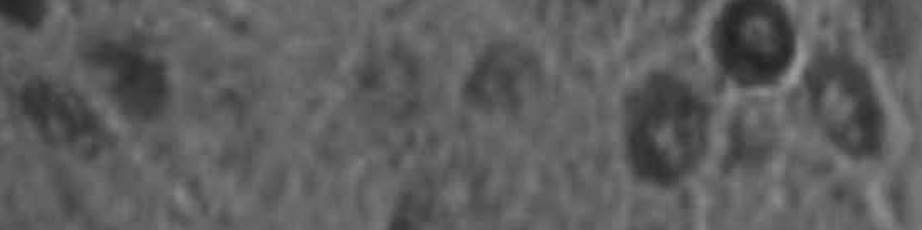

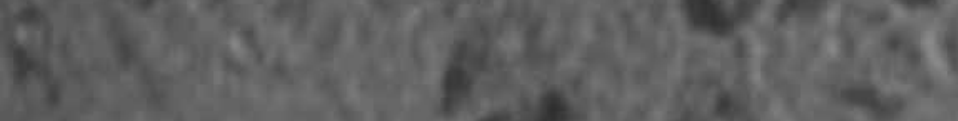

Q.

8

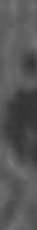

3. 14

Tive

tras

is

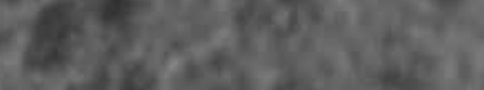

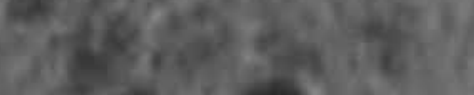

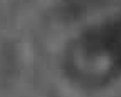

$a^{3}-1+x+2$

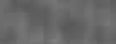

